
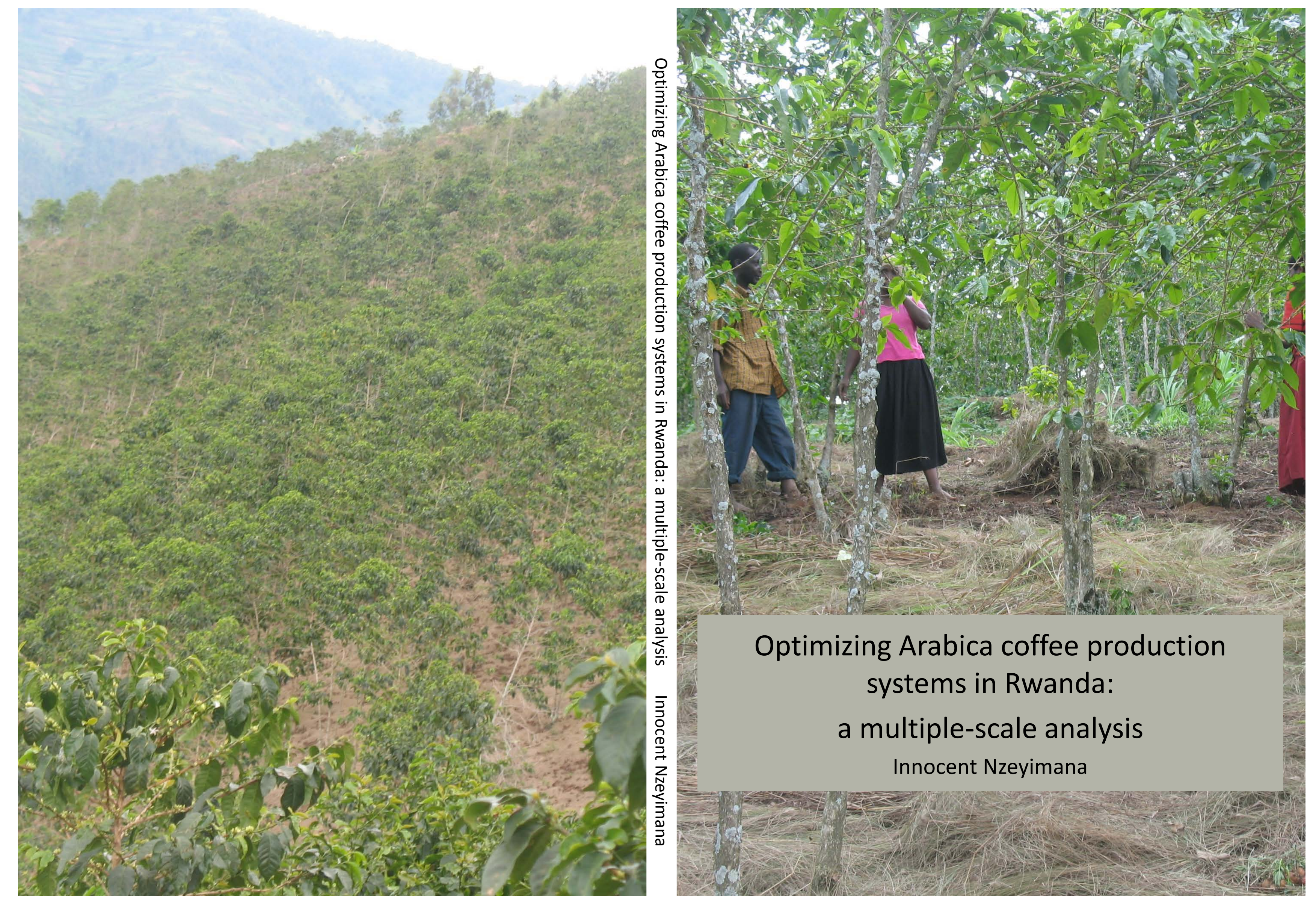


\section{PROPOSITIONS}

1. Adding high quantities of organic mulches to soils does not necessarily improve soil quality. (this thesis)

2. Mineral fertilizers applied in coffee farming in Rwanda cannot be completely substituted by organic mulching.

(this thesis)

3. Preventing and remediating erosion-induced soil and nutrient losses in Rwandan mountainous regions will enhance agricultural production.

4. Farmers might invest much but end up with low revenues, indicating that expected costs and benefits should be accounted for to improve farm performance.

5. Research findings get value when you timely and effectively communicate them to relevant audiences.

6. Doing a PhD is like a journey ending with interesting and sometimes unexpected results, as well as opportunities for further investigations to advance science and inform society.

7. For success in life it is essential to be confident, believe in your own capacities and work hard.

Propositions belonging to the thesis, entitled:

"Optimizing Arabica coffee production systems in Rwanda: a multiple-scale analysis"

Innocent Nzeyimana

Wageningen, $6^{\text {th }}$ June 2018 


\section{Optimizing Arabica coffee production systems in Rwanda: a multiple-scale analysis}




\section{Thesis committee}

\section{Promotors}

Prof. Dr Violette Geissen

Personal chair at the Soil Physics and Land Management Group

Wageningen University \& Research

Prof. Dr Coen J. Ritsema

Professor of Soil Physics and Land Management

Wageningen University \& Research

\section{Co-promotor}

Prof. Dr Alfred E. Hartemink

Chair and Professor of Soil Science

University of Wisconsin - Madison, USA

\section{Other members}

Prof. Dr O. Oenema, Wageningen University \& Research

Prof. Dr A.D. Ferreira, Coimbra Polytechnic Agriculture School, Portugal

Dr E. Smaling, Wageningen University \& Research

Dr C. van Beek, SoilCares Foundation, Wageningen, the Netherlands

This research was conducted under the auspices of the Research School for C.T. de Wit Graduate School for Production Ecology and Resource Conservation (PE\&RC) 


\title{
Optimizing Arabica coffee production systems in Rwanda: a multiple-scale analysis
}

\author{
Innocent Nzeyimana
}

Thesis

submitted in fulfilment of the requirements for the degree of doctor

at Wageningen University

by the authority of the Rector Magnificus,

Prof. Dr A.P.J. Mol,

in the presence of the

Thesis Committee appointed by the Academic Board

to be defended in public

on Wednesday 6 June 2018

at 11 a.m. in the Aula. 
Innocent Nzeyimana

Optimizing Arabica coffee production systems in Rwanda: a multiple-scale analysis, 141 pages.

PhD thesis, Wageningen University, Wageningen, the Netherlands (2018)

With references, with summaries in English and Dutch

ISBN: 978-94-6343-279-5

DOI: https://doi.org/10.18174/448555 


\section{Table of contents}

Chapter 1. General introduction .............................................................................. 7

Chapter 2. Coffee farming and soil management in Rwanda ................................ 21

Chapter 3. GIS-based multi-criteria analysis for Arabica coffee expansion in Rwanda.

Chapter 4. Mulching as a strategy to improve soil properties and reduce soil erodibility in coffee farming systems of Rwanda. .53

Chapter 5. Mulching effects on soil nutrient levels and yield of coffee farms in Rwanda. 71

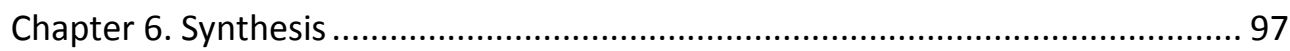

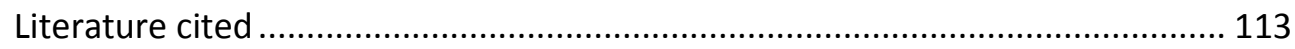

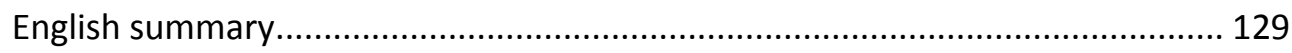

Nederlandse samenvatting....................................................................... 131

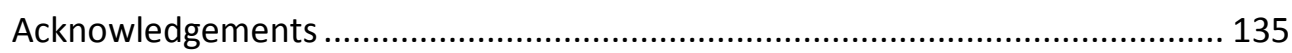

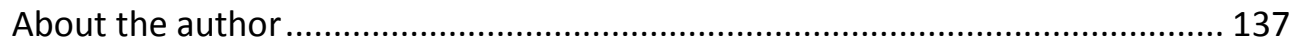

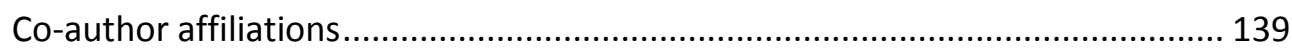




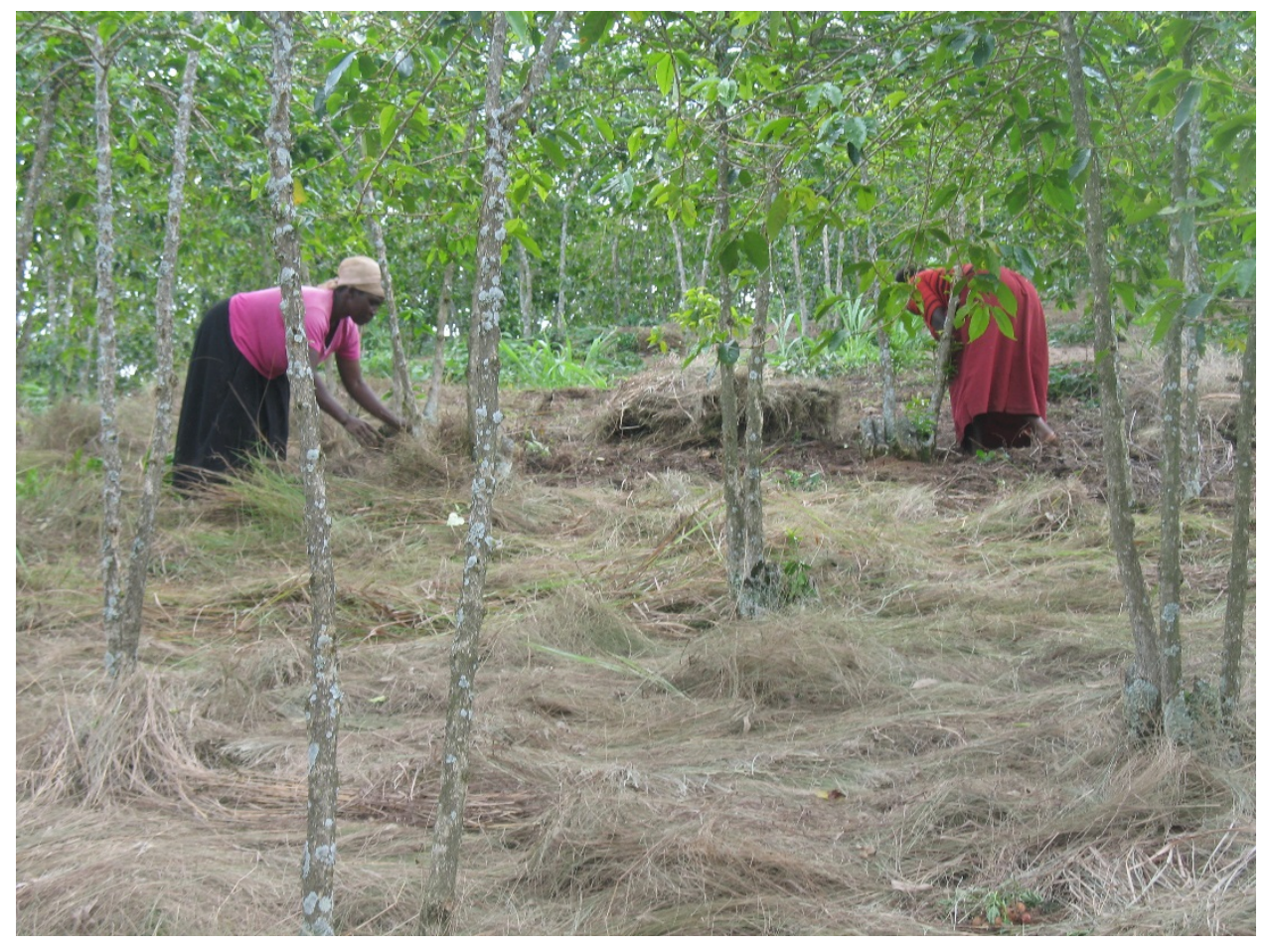


1. General introduction 


\subsection{Arabica coffee production in Rwanda}

Coffee is one of the most important and valuable commodities in the world of agriculture, and a major foreign exchange earner for many developing countries. In the Eastern and Central African countries, like Ethiopia, Kenya and Rwanda, coffee is one of the top export commodities that contribute to the national economy. In Rwanda, coffee remains one of the major export products, contributing more than $45 \%$ of the value of export crops (NISR, 2015). In 2014, the Rwanda agriculture was the leading sector in the economy and contributed about $33 \%$ to the GDP; the coffee sub-sector contributed about $1 \%$ of the Rwanda's GDP (NISR, 2015).

Coffee was introduced for the first time in Rwanda by German Missionaries in 1904, and in the beginning it was mainly cultivated by the colonial administration. The production of coffee has increased through the years and reached its peak in the mid-1980s. From 2000, the Government of Rwanda (GoR) introduced a new coffee strategy that aimed at promoting the cultivation and production of new high-quality coffee varieties following the increasing interest from international companies on Rwandan specialty coffee. Between 2002 and 2011, the coffee production increased by $20 \%$, whereas coffee exports increased by $150 \%$ (NAEB, 2011).

The GoR understands that, strategically, the coffee sector should promote the cultivation and production of high-quality coffee. Since 2000 , the GoR has focused more attention on the strategic development of the industry. This has involved the development of land use plans, farmer cooperatives as well as programs to stimulate the market, e.g. the Rwanda Cup of Excellence. Since the implementation of the national land use consolidation policy in 2007 , total coffee plantation area has increased from 30,000 ha to 55,030 ha (Nzeyimana et al., 2014). Rwanda now produces between 16,000 and $20,000 \mathrm{MT}$ of coffee annually, with a productivity index of approximately 0.4 to 0.6 ton ha ${ }^{-1}$ of green coffee (NISR, 2015). As a result of the increased focus by the GoR, not only coffee production has increased, Rwandan coffee has also received increasing interest and recognition from international companies. In 2015, Rwandan coffee was ranked among the top 30 leading coffees in the world by Coffee Review (http://www.coffeereview.com/top-30-coffees-2015/).

Despite the impressive progress, Rwanda's coffee productivity index is low by comparison to the potential productivity, and the livelihoods of the approximately 400,000 smallholder farmers remain marginal. This is largely due to low soil fertility in the areas where the coffee is grown and soil erosion which causes additional nutrient losses. Developing effective means to address these issues holds great promise for improving Rwandan coffee quality and productivity as well as the livelihoods of the coffee farmers. 


\subsection{Agro-ecological conditions for growing Arabica coffee and constraints}

Arabica coffee is normally grown in elevated areas of the tropics and sub-tropics that have an optimum daily temperature of between 20 to $24^{\circ} \mathrm{C}$. Temperatures greater than $30^{\circ} \mathrm{C}$ cause plant stress; and temperatures of less than $15^{\circ} \mathrm{C}$ limit plant growth and are considered sub-optimal. Elevation of about 1000m asl, annual rainfall of between 1400 and $2000 \mathrm{~mm}$, around $60 \%$ relative humidity, and sunlight of between 2200 and 2400 hours per year, are favourable climatic conditions for growing Arabica coffee (Descroix and Snoeck, 2004).

Arabica coffee has specific soil requirements as well. To get a good quality production, Arabica coffee usually needs a well-drained soil that has at least one-meter soil depth. Arabica coffee prefers soils with a total porosity of 50 to $60 \%, 2$ to $5 \%$ organic matter content, 45\% minerals content and a soil pH that varies between 5 and 7 (Wintgens, 2012). In some respects, Rwandan soils are well suited for coffee production, however they are also strongly depleted and susceptible to erosion. Restoring and maintaining these soils, thus to improve coffee productivity, remain a major challenge for the smallholder farmers.

In Rwanda six Arabica coffee varieties such as Bourbon Mayaguez (BM) 139, BM 71, Harar, Jackson 2/1257, Pop 3303/21 and Mibilizi are grown (Bigirimana et al., 2012). These Arabica varieties are mainly grown on steep slopes that can exceed $55 \%$ in the middle altitude regions like the Kivu Lake shores, Impala, Central Plateau, Mayaga and Bugesera. All these areas are quite well supplied by rain. Optimal growing conditions have been observed on the shores of Kivu Lake, in the Western region. The Central Plateau, Impala, Mayaga and Bugesera agro-ecological zones are moderately suitable, with their slightly lower rainfall providing some constraints to the optimal production conditions for Arabica coffee. In the highlands like the Congo-Nile Watershed Divide agro-ecological zone, the relatively high rainfall and high altitude contribute to high soil degradation and limit the optimal production conditions (see Section 1.7). 


\subsection{Smallholder coffee farming systems in Rwanda}

The approximately 400,000 smallholder farms producing coffee in Rwanda are scattered across hilly areas and steep slopes. The farmers face serious problems with soil erosion and loss of soil fertility, both of which result in low coffee productivity and thus, low farmers' incomes. Mulching is one of the farming practices that have been adopted by some farmers to try to address these issues. Mulching is believed to have a positive effect on reducing erosion rates and improving the soil fertility on the sloping lands.

In Rwanda, smallholder coffee farming systems are characterised by the size of the coffee farm, the number of coffee trees, the coffee planting/cropping system, i.e. being a pure stand coffee (monoculture) or being intercropped with annual or perennial crops, and the land management practices. These farming systems are mainly characterised by smallholder farms of less than 1 hectare on average, and that have less than 200 coffee trees. Due to land scarcity and pressure most of the coffee farms are under intercropping systems with perennial or annual food crops (Fig. 1.1). Crops used in this system include bananas, sweet potatoes, taro, cassava, yams, and beans, among others. The cultivation of these crops, between rows of coffee plants, is a traditional practice among smallholder farmers who are keen to make the smallest plot of land as profitable as possible. According to Bigirimana et al. (2012), the smallholder coffee farmers practice intercropping on less than $10 \%$ of their farm area.

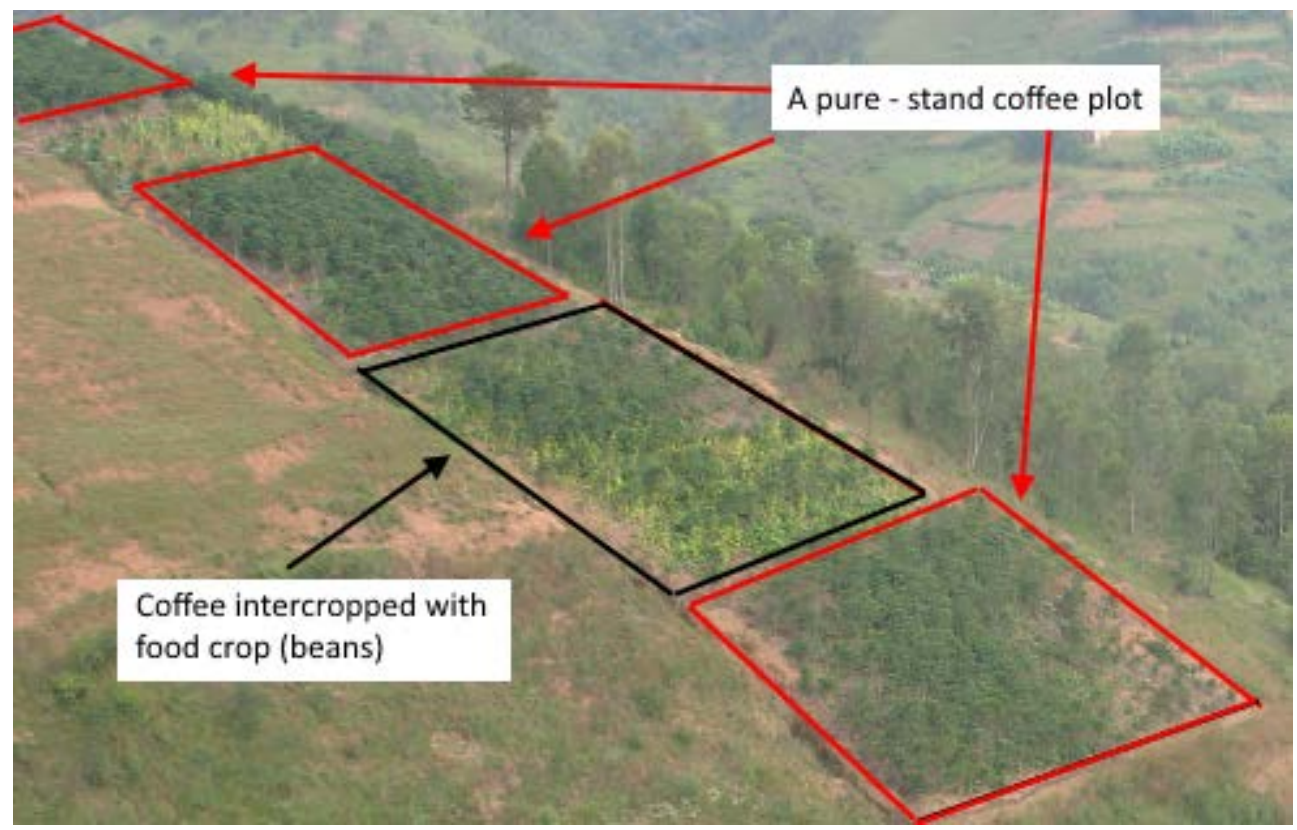

Figure 1.1 Typical smallholder coffee farming system in Rwanda 
Growing food crops between coffee trees may contribute to weed suppression and increase soil cover, which can reduce erosion; but the practice may also result in excessive competition on soil nutrients, leading to reduced coffee yield if the agronomic practice is maintained over a long period. In addition, intercropping with food crops can increase soil loss when appropriate land management practices are not adopted. The land management practices, like mineral fertiliser application, liming and mulching, which are applied in the coffee farms are intended to improve the poor soil fertility conditions of the smallholder farms.

The GoR would like to improve farm livelihoods through the sustainable growth of high quality coffee. This would be a win-win situation because increased production of high quality coffee could increase Rwanda's export earnings as well as improved farm livelihoods. A study of agricultural development in Africa has shown that successes are often linked to cash crop components; food crops will profit as a spin-off of improved cash income (Gabre-Madhin and Haggblade, 2004). Such development can be achieved if sustainable best practices or technologies in agriculture are identified, and can give farmers sufficient benefits with respect to what they invest in coffee production.

The use of mulch is based on its availability and the quality of the mulching material used. Plant species and crop residues used as mulching materials are easily identifiable and well known by the smallholder coffee farmers, and are also readily available, although accessibility in large quantities is still a problem. Although mulching is a quite common practice, no scientific studies have been carried out in Rwanda on the actual effects of different types and quality of mulch on erosion control and soil fertility restoration in smallholder coffee farming systems. Conducting such research will contribute to development of best practices to optimize management practices for the production of Arabica coffee.

\subsection{Mulching as land management practice for erosion control and soil fertility restoration in smallholder coffee farming systems}

Smallholder farmers are usually interested in cost-effective and locally available technologies that can contribute to increased productivity. Mulching is an affordable agronomic practice; it has been found to be economically attractive to smallholder farmers as compared to mineral fertilisation (Sanchez and Jama, 2002). It has been adopted by smallholder farmers throughout sub-humid and semi-arid regions of the Sub-Saharan Africa (SSA) to reduce soil losses by water (Araya and Stroosnijder, 2010), improve soil fertility and crop yield through supply of plant nutrients that are contained in the mulch materials 
(Awopegba et al., 2017; Liu et al., 2017; Ngoma et al., 2015), and maintain long-term sustainable soil management (Masvaya et al., 2017). Besides providing organic nutrients, mulching has the potential to conserve soil moisture content (Ram et al., 2016) and to increase water availability for crops (Cerdà et al., 2016; Liu et al., 2017) (Fig. 1.2). Additional studies have shown that, besides the above benefits, mulching can also contribute to suppressing weed growth (Lalljee, 2013; Manjith and Angadi, 2016).

In densely populated countries subjected to land scarcity and pressure on steeply sloping cropland, the use of mulching is still very limited, especially amongst smallholders, due to its lack of availability - there are no additional lands available to produce organic mulch materials. Therefore, mulches are collected elsewhere, including the food crop fields outside the coffee plots. The coffee farmers use different types of mulching materials, including annual crop residues, leaves and branches of agro-forestry and forestry trees.

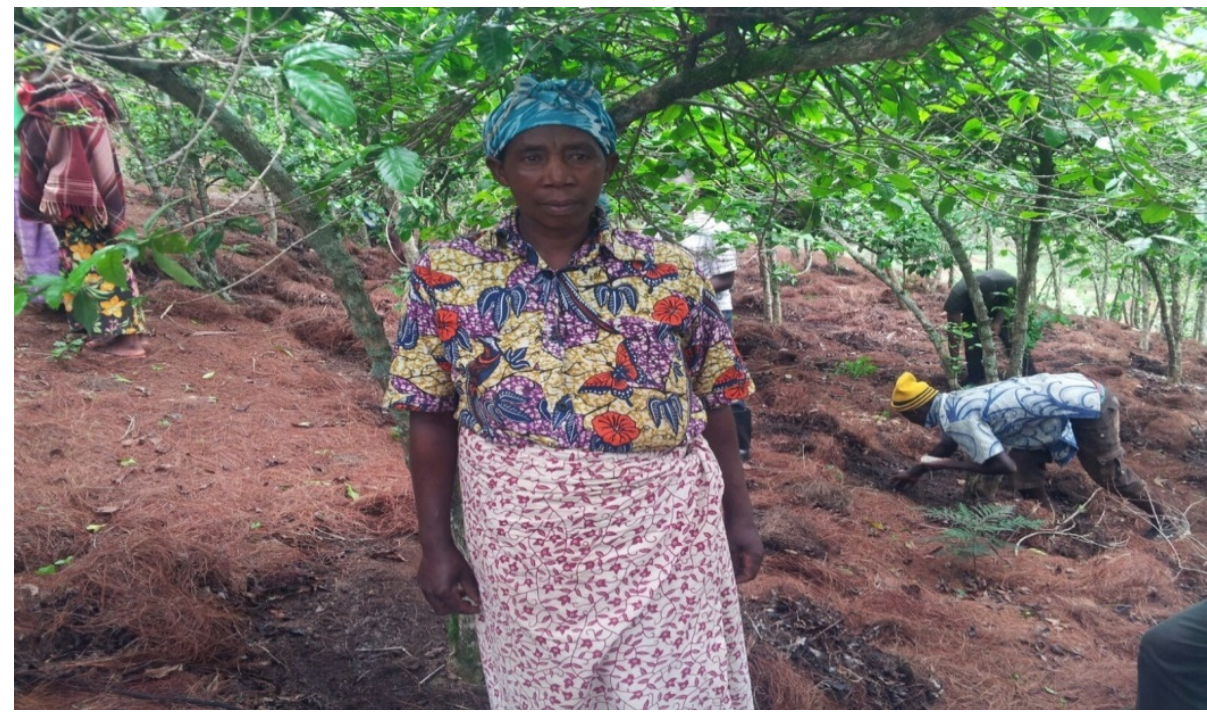

Figure 1.2 Mulching (composed of beans' residues and Eucalyptus leaves) adopted by smallholder farmers in coffee farming system 


\subsubsection{Mulching for erosion control in smallholder farming systems}

Mulching materials applied as surface cover protect the soil against erosion. The mulch buffers the soil against raindrops that can dislodge soil particles which are then transported down slope with runoff. Instead, the raindrops fall on the mulching material and the water then filters through the mulch to the soil surface, thus reducing the runoff velocity and, consequently, the risk of accelerated erosion (Morgan, 2005). Mulching has been demonstrated to be effective not only in reducing surface runoff and soil losses, but also in maintaining soil structure, conserving soil water and improving soil organic matter content (Giller et al., 2009; Karami et al., 2012; Mwango et al., 2016; Nzeyimana et al., 2017). Research findings show that the application of mulch is effective when the soil cover is above $70 \%$ of the ground surface (Morgan, 2005). The effectiveness of mulch for soil protection depends on the amount of mulch applied (Mulumba and Lal, 2008), slope gradient, soil type, land use, soil management practices, and rainfall erosivity (Smets et al., 2008).

In Rwandan smallholder coffee farming, mulching is also practiced to protect the soil from erosion and the continuous loss of soil nutrients. As a perennial crop, coffee should protect the soil against erosion better than an annual crop because of its year-round soil cover (Hartemink, 2006). However, the density of trees in smallholder coffee farming is low with less than 2,500 trees ha- ${ }^{-1}$, which limits the soil cover, and thus, part of the field becomes vulnerable to soil erosion.

Soil erosion losses can be considerable in smallholder coffee plantations that have no adequate mulching, or that have a low planting density with little natural mulch formed by litter. This is especially important for coffee grown in highlands on steep slopes and in new established coffee plantations. Thus, mulching should be tested on the sloping lands of Rwanda to understand its effects on reducing erosion and, at the same time, improving soil fertility, and thus increasing coffee productivity. The understanding of these effects could be an opportunity for smallholder farmers with limited funds to purchase fertilisers to improve their livelihood.

\subsubsection{Mulching for soil fertility restoration in smallholder farming systems}

In Rwanda, coffee yields are mainly limited by soil nutrient deficiencies. The production of a ton of coffee beans requires a withdrawal of approximately $63.6 \mathrm{~kg} \mathrm{~N}, 12 \mathrm{~kg} \mathrm{P}_{2} \mathrm{O}_{5}$ and 87.3 $\mathrm{kg} \mathrm{K}_{2} \mathrm{O}$ (Nair, 2010). Deficiencies in these nutrients has been documented to have negative effects on coffee growth and yield, with Nitrogen ( $N$ ) and Potassium (K) being the most 
limiting nutrients in coffee production (Cordingley, 2009; Van der Vossen, 2005; Wang et al., 2015). Nitrogen deficiency is mainly observed on degraded soils and badly managed soils, and can lead to decreased coffee production (Fig. 1.3). Additional N, P, and K can be provided through mulching, depending on the type of mulch (Wintgens, 2012). Thus, mulching can offer an opportunity for smallholder farmers (with limited funds to purchase mineral fertilisers) to improve soil fertility conditions and increase crop yields (Mupangwa et al., 2013; Mwango et al., 2016).

Specifically, mulching with crop residues has the potential to reduce and reverse the physical, chemical and biological degradation of soils under different climatic conditions and soil types (Daraghmeh et al., 2009; Nzeyimana et al., 2017). Annual mulch application of crop residues has also been found to significantly enhance the contents of $\mathrm{N}$, soil organic $\mathrm{C}$, P, K, Ca and Mg (Fang et al., 2008; Mwango et al., 2016; Tsozué et al., 2015). The crop residues were the major sources of these nutrients in soils and are critical to improving efficiently the crop productivity (Tsozué et al., 2015). Nitrogen mineralisation proceeds more rapidly in residues rich in $\mathrm{N}$ and $\mathrm{P}$, or in residues with a low $\mathrm{C} / \mathrm{N}$ ratio (Abbasi et al., 2015; Nikolaidou et al., 2010). Generally, residues high in $P$, or with a low C/P ratio or N/P ratio, release more $P$ within a shorter period (Baggie et al., 2004; Rezig et al., 2013; Vanzolini et al., 2017). Thus, high quality residues release nutrients rapidly, while nutrients from low quality residues are initially immobilised, and later are eventually mineralised and become available to crops (Herencia and Maqueda, 2016; Jensen et al., 2005; Xavier et al., 2013).
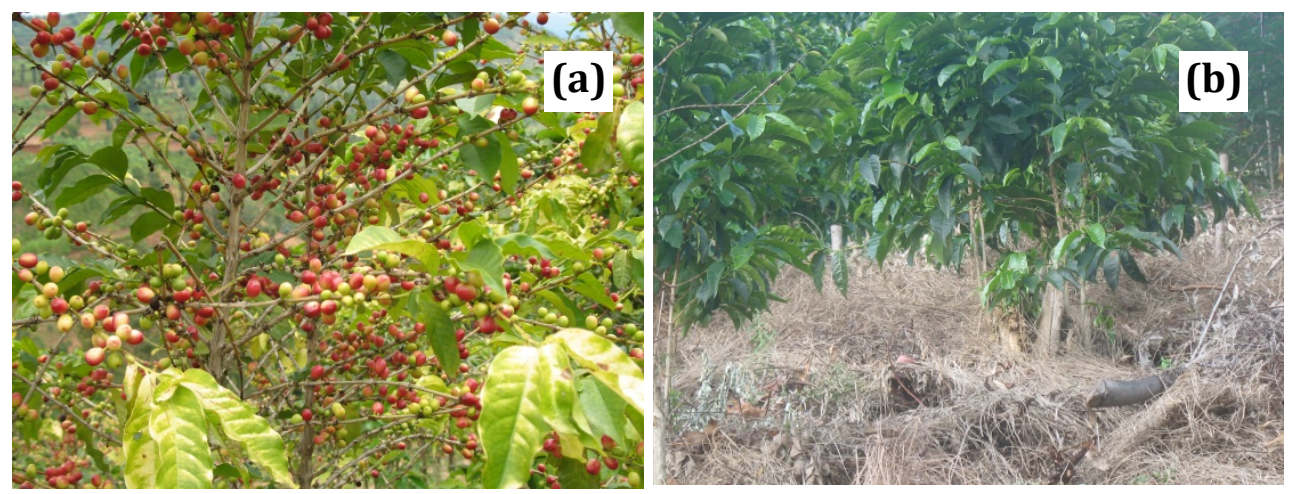

Figure 1.3 (a) Coffee trees showing $N$ deficiency; (b) Healthy coffee trees mulched with Eucalyptus leaves mixed with food crops' residues

Different crop parts, like pods, cobs and heads of soybean, sunflower and maize, are of better quality for nutrient release compared to stems and stalks, and have different rates of decomposition (Kalburtji and Mamolos, 2000). The amount of nutrients released during crop residue decomposition is mainly regulated by the crop residue biomass loaded 
(Vanzolini et al., 2017), the residue chemical composition (Herencia and Maqueda, 2016), the climatic conditions and soil types (Sariyildiz and Anderson, 2003). It is highly influenced by the soil fertility conditions (Lal, 2015), and can lead to a reduction in mineral fertiliser application (Kwabiah et al., 2003).

Mulching with residues from multipurpose agro-forestry trees has also been proven to be a good source of nutrients to crops in the absence of mineral fertilisers (Bucagu et al., 2013). The tree residues serve mainly as natural resource options for supplying soil organic $\mathrm{C}$ and soil $\mathrm{N}$, but also for other major nutrients through biological mineralisation, and this has resulted in increased crop yields (Mwango et al., 2016; Rezig et al., 2013; Shisanya et al., 2009). In coffee farming systems, the use of mulch of Tephrosia vogelii at $2.5 \mathrm{t}$ of dry matter $\mathrm{ha}^{-1}$ in combination with NPK fertiliser and $1.41 \mathrm{t} \mathrm{ha}^{-1}$ resulted in a $33 \%$ increase in yield, from $2.1 \mathrm{t} \mathrm{ha}^{-1}$ to $2.8 \mathrm{t} \mathrm{ha}^{-1}$ (Bucagu et al., 2013).

\subsection{Objectives of the study and the research questions}

The aim of this study is to develop best land management options for Rwanda smallholder coffee farming, in order to ensure sustainable production of high quality coffee. For decision and policy makers, this study will provide information and key strategies about adequate regions for coffee production in Rwanda, potential yields and best practices. It is hypothesized that smallholder coffee farms have low yield but with improved soil husbandry, especially by controlling soil erosion and maintaining soil fertility of poorly managed fields; coffee yields can be increased, and therefore farmers' revenues and livelihoods will be improved through sustainable growth of high quality coffee. Improving the soil fertility alone is a waste of effort without adequate erosion control practices as most of the coffee is grown on degraded soils located on unprotected steep slopes without soil cover. The availability of mulch and organic matter is limited; and thus, most of the coffee fields are subject to soil erosion by water and soil nutrient losses.

To achieve the above overall goal, soil erosion control and soil fertility were studied in three major coffee production zones of Rwanda. The following research questions are addressed:

1. What are the major areas for Arabica coffee production and their bio-physical characteristics in Rwanda?

2. What are the potential and expected productivity indices in the major production zones in Rwanda?

3. What are the effects of mulching, as a major land management option, on soil erosion control and soil fertility improvement? 
4. What are the effects of mulching, as a major land management used at the farm level, on increasing Arabica coffee yield?

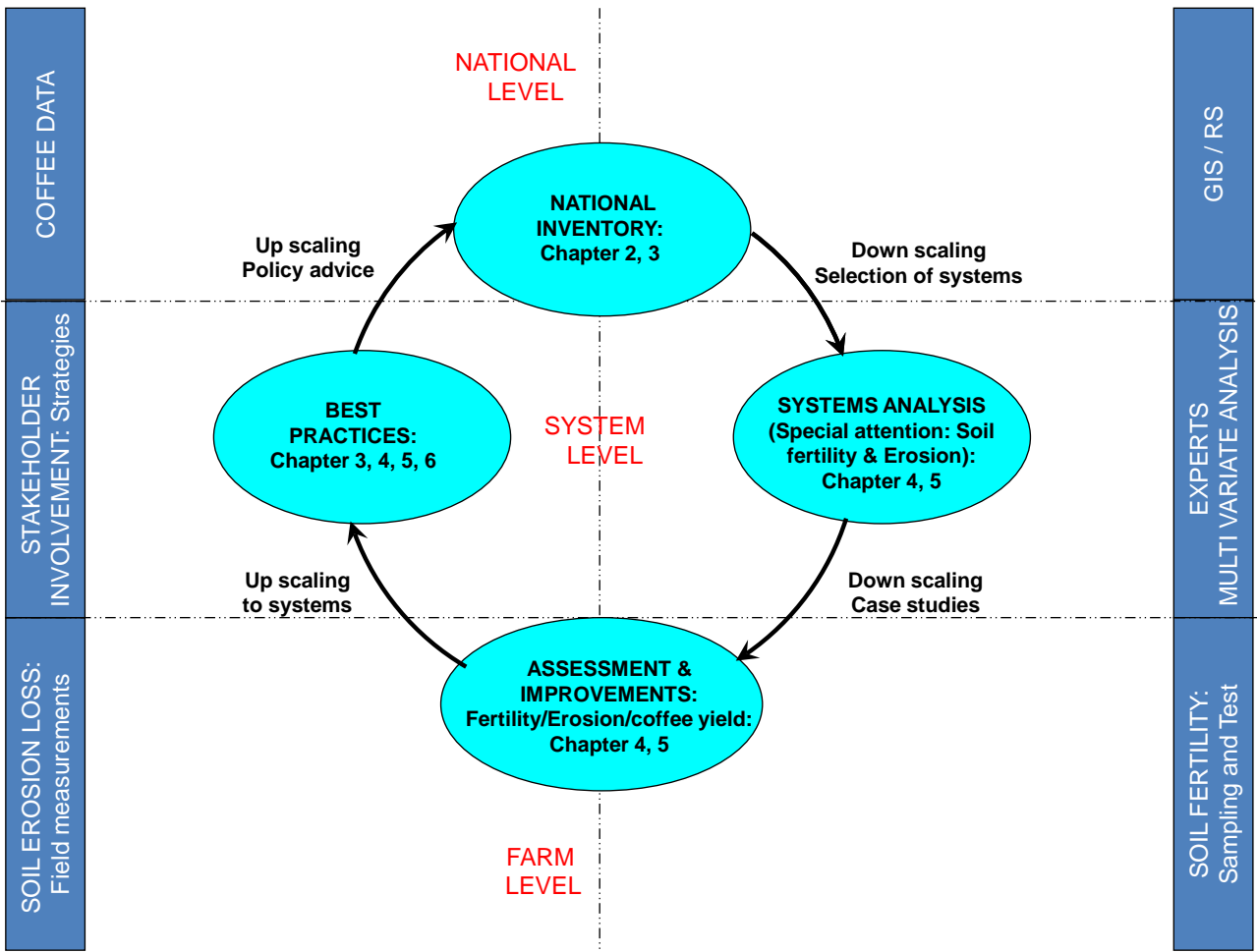

Figure 1.4 Flow chart for the analysis at different scales for the "Optimizing Arabica Coffee production systems in Rwanda: a multiple-scale analysis" Thesis

To address the above questions, an analysis has been conducted at three (3) levels, national, system, and farm, as illustrated in the conceptual diagram (Fig. 1.4). The study brings in a new approach of problem analysis, which starts with a GIS spatial analysis at national level to identify and characterise major coffee production zones, using a micro-model that analyses the spatial coffee database based on agro-climatic conditions, soils, and topography (i.e. slope steepness). Then, zooming into system and farm levels, this study analyses and presents experimental results on the effects of different mulching systems, identified at farm level, on soil erosion control, soil fertility improvement and coffee yield. Ultimately, this project proposes best land management options that can be scaled up to the country level to ensure sustainable coffee production. 


\subsection{Thesis outline}

The above research questions are addressed in the following chapters (Chapters 2 to 6 ). The GIS spatial analysis of the coffee production systems at national level is addressed in Chapters 2 and 3 . Chapters 4 and 5 cover the research conducted at system and farm levels. A synthesis of the entire project is presented in Chapter 6 . Chapters 3 through 6 also address up-scaling best practices to country level again.

Chapter 2 characterises the coffee farming systems and soil management in Rwanda, based on data collected from literature. Chapter 3 assesses the potential production zones for Arabica coffee expansion, the analysis of productivity levels and the prediction of potential yields to facilitate extension services to the smallholder farmer and to effectively inform the decision and policy makers. Chapters 4 and 5 report on the effects of mulching as a strategy to control water erosion and improve soil fertility in coffee farming systems respectively. To date, Chapters 2, 3 and 4 have been published, and Chapter 5 has been submitted to an international peer reviewed journal.

Chapter 6 presents a synthesis of the research findings, and highlights sustainable best practices to improve smallholder coffee farming. Chapter 6 also presents key policy strategies and recommendations to improve coffee productivity of smallholder farmers in Rwanda.

\subsection{Study area}

The study sites were located in the Kibirizi Sector of Nyamagabe District in Rwanda's Southern Province, the Ruli Sector of the Gakenke District in the Northern Province, and the Gishyita-Mubuga Sectors of Karongi District in the Western Province (Fig. 1.5). The sites are located in different agro-ecological zones.

Kibirizi is located in the cold and humid southern highlands at the Congo-Nile Watershed Divide agro-ecological zone, with altitudes varying between 1900 and $2500 \mathrm{~m}$ a.s.l.; the annual minimum and maximum temperatures average between 14 and $24^{\circ} \mathrm{C}$, and the annual rainfall averages fall between 1300 and $2000 \mathrm{~mm}$. The soils vary between sandy loam, loam and clayey soils, but are mainly dominated by clayey soils and clayey loam derived from schistose materials. According to the Soil Taxonomy, they are classified as Ultisols and Inceptisols. They are acidic, and their nutrient availability is poor (Birasa et al., 1990). 
The Ruli site is located in the cold and humid northern highlands at the Central Plateau and granitic ridges, with elevations between 1900 and $2300 \mathrm{~m}$ a.s.l.; the annual temperatures vary between 16 and $29^{\circ} \mathrm{C}$, and the annual rainfall varies between 1100 and $1500 \mathrm{~mm}$. The soils are dominated by sandy clay loam and sandy loam soils, developed from granite, and are mainly classified as Inceptisols, Ultisols and Alfisols according to Soil Taxonomy (Birasa et al., 1990).

The Karongi site is located in the western middle altitude, with the cool climate of the Lake Kivu shores, and soils are dominated by sandy clay loam and sandy loam soils, derived from shales and granites. According to Soil Taxonomy, these soils are mainly classified as Inceptisols and Ultisols (Birasa et al., 1990). Except for the abrupt slopes that are strongly eroded, the level of soil fertility is moderate. The altitude varies between 1500 and $1900 \mathrm{~m}$; the annual rainfall and temperature vary from 1200 to $1300 \mathrm{~mm}$ and from 19 to $22.5^{\circ} \mathrm{C}$, respectively (Verdoodt and Van Ranst, 2003). 


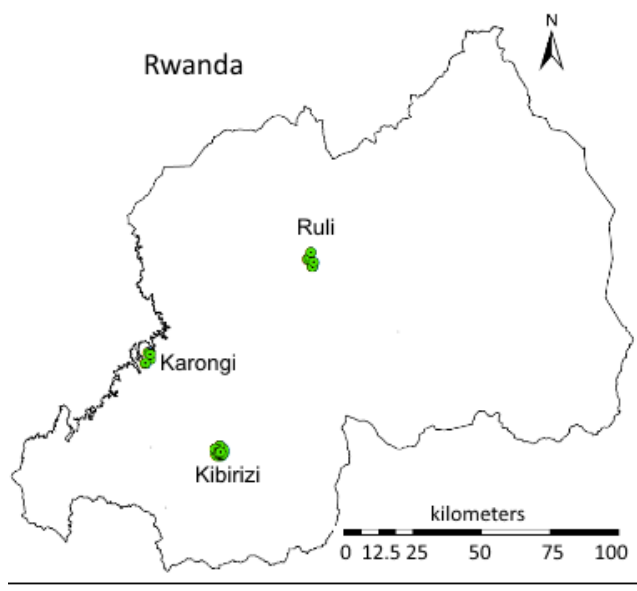

Legend

Study site
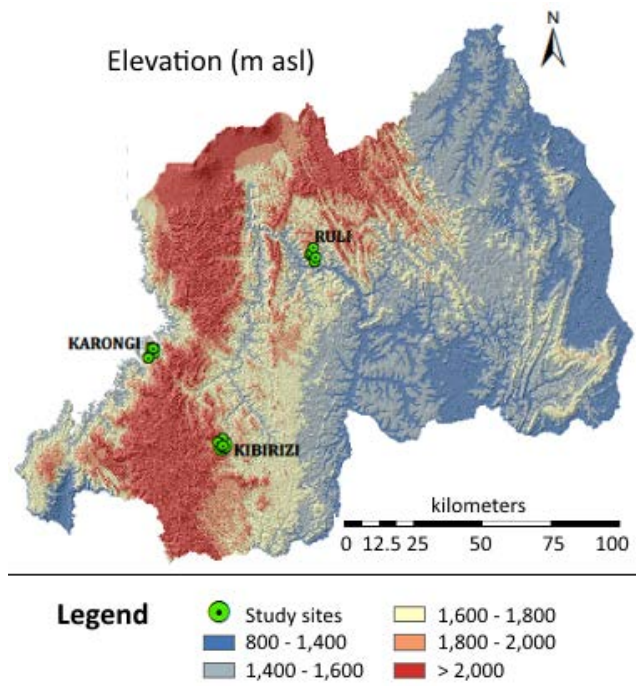

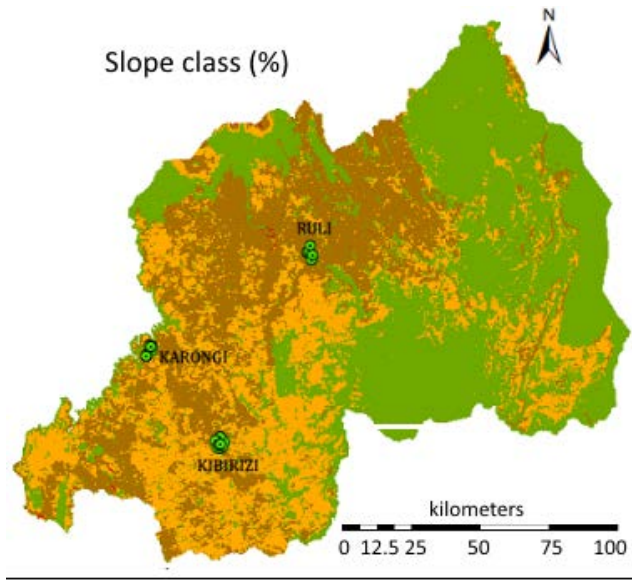

Legend

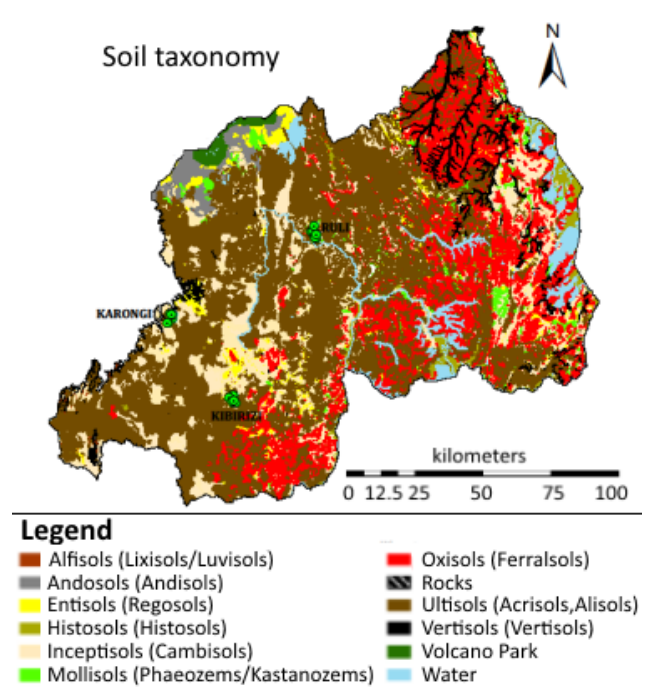

Figure 1.5 Location and characteristics of the study area (to be continued on next page) 

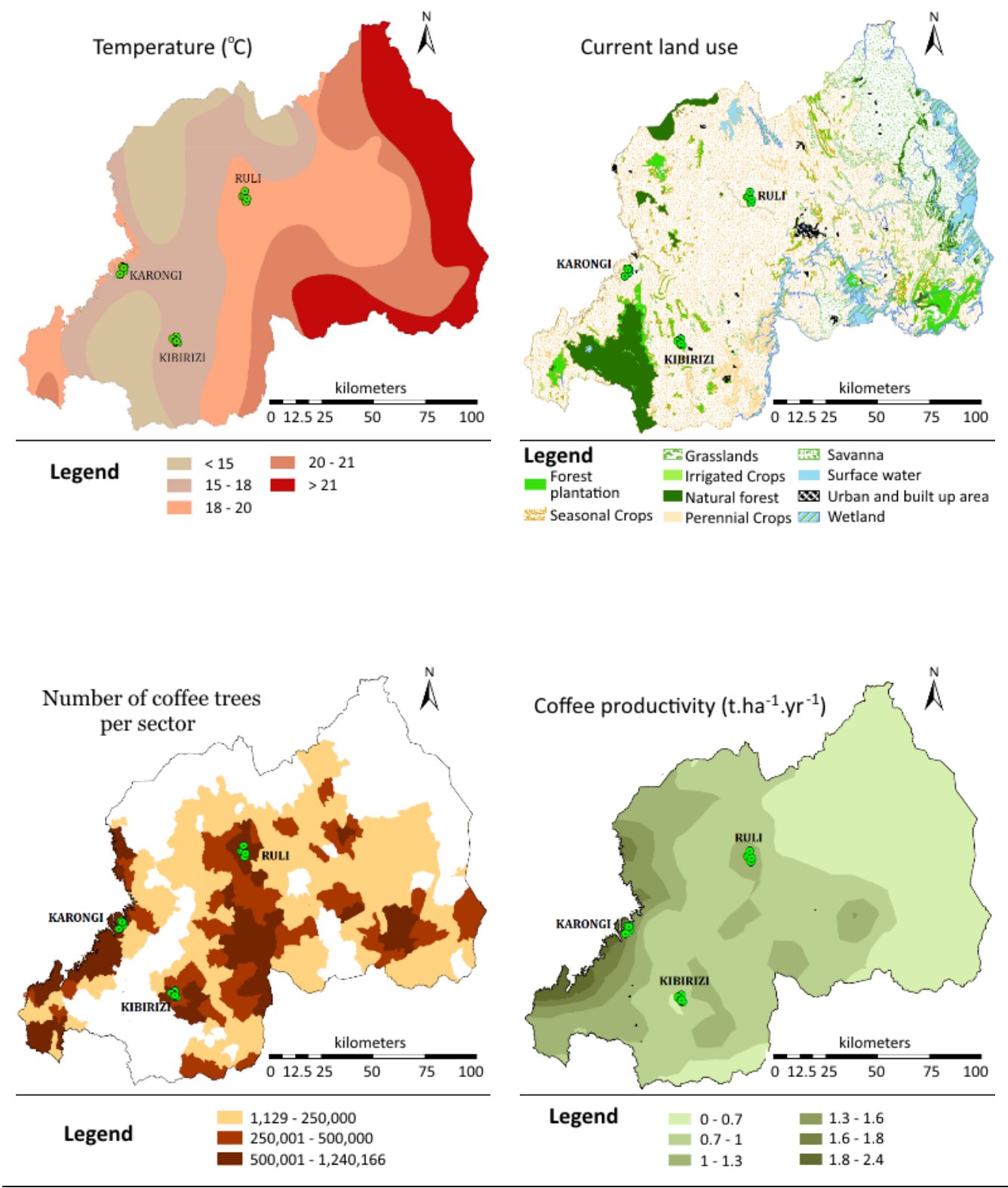

Figure 1.5 Location and characteristics of the study area (continued) 


\section{Coffee farming and soil management in Rwanda}

Agriculture is the leading sector in the Rwanda's economy. Here we review how it is grown and what soil management practices are currently being used and should be used to enhance coffee production. Coffee cultivation covers around $2.3 \%$ of the total arable land, and the crop is grown by smallholder farmers who cultivate on average less than one hectare land. Rwanda produces high-quality specialty or fully washed coffee. The coffee is intercropped with annual crops due to land scarcity and this enables farmers to achieve a more efficient combination of food and cash crops. The soils are mainly derived from Precambrian and Quaternary parent materials. About $87 \%$ of the soils have $\mathrm{pH}<5.2$ and are strongly $P$ deficient. Reduced land fragmentation, increased organic and inorganic fertilizer applications and mulching is needed to boost coffee yield. Mulching improves soil chemical and physical properties; it controls erosion which is a serious problem in coffee farming systems on steep slopes and when the coffee is young or grown at low planting densities. $A$ significant increase in coffee production in Rwanda can only be achieved with improved soil management including increased inorganic fertilizer inputs.

Based on: Innocent Nzeyimana, Alfred E. Hartemink, Jan de Graaff. 2013. Coffee farming and soil management in Rwanda. Outlook Agriculture 42 no. 1: 47-52 


\subsection{Introduction}

In Rwanda, coffee was introduced by German Missionaries in 1904 and in the beginning it was mainly cultivated by the colonial administration. The production of coffee has increased through the years and reached its peak in the mid 1980s. In 1987, the maximum of 43,000 tons of semi-washed coffee was produced (Fig. 2.1). During the years that followed, the production dropped to an annual average of 26,000 tons, mainly due to the age of coffee trees, decline of soil fertility, low coffee price to the farmer, and the 1994 genocide.

From 2000, coffee from Rwandan received increasing interest from international companies, and in 2002, the Government of Rwanda issued a National Coffee Strategy to promote the cultivation and production of high-quality coffee. Between 2002 and 2011, the coffee production increased by $20 \%$, whereas coffee exports increased by $150 \%$ (Fig. 2.2) (NAEB, 2011). Over the same period, increases of $20 \%$ and $8 \%$ per year were observed in Vietnam and Brazil (D’haeze et al., 2005).

In 2010, coffee production occupied 33,000 ha, around $2.3 \%$ of the total cultivated land, producing 19,320 tons of coffee (NAEB, 2011). The price of the coffee cherries to the farmer increased from 250 to 1,200 RwF kg-1 between 2000 and 2010 (Fig. 2.2). Rwanda used to produce semi-washed or semi-processed and ordinary coffee of low-quality, which was sold at a lower price than specialty coffee that shows less price fluctuations than semi-washed coffee. At low coffee prices, farmers lacked revenues to invest in improvements. With the implementation of a new coffee strategy, the Government promoted new high-yielding coffee varieties to increase coffee production.

Coffee production is currently undergoing a major shift - the aim is to produce more coffee of higher quality. Importantly, this will be influenced by the way that the crop is cultivated. This paper reviews soil management strategies for improved coffee production in Rwanda - now and in the future. 


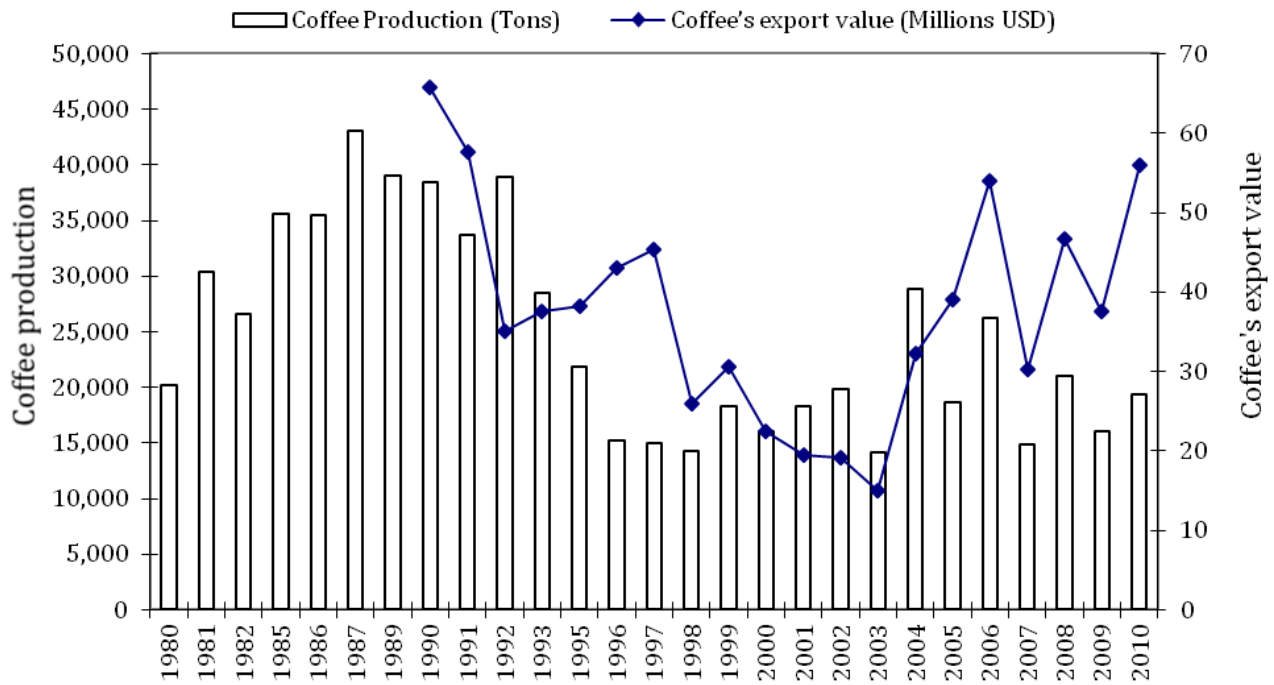

Figure 2.1. Coffee production and export value in Rwanda (NAEB, 2011)

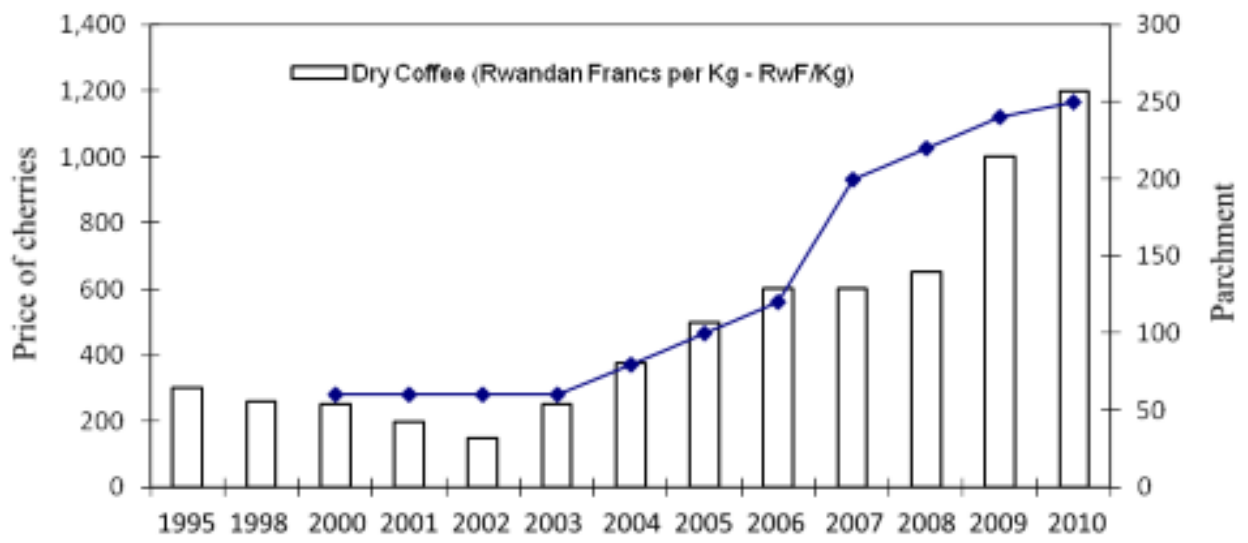

Figure 2.2. Price of parchment coffee and cherries to the farmer in Rwanda (NAEB, 2011). Cherries are fresh coffee with the outer red pulp, while parchments are coffee beans that the outer pulp has been removed using a pulping machine 


\subsection{Soils and soil fertility in Rwanda}

In Rwanda, there is a reasonable body of knowledge on the soil and soil fertility, including: Mutwewingabo (1989); Birasa et al. (1990); Yamoah et al. (1990); Mbonigaba (2007); Mbonigaba et al. (2009); Mukuralinda (2007). The soils of Rwanda are mainly derived from Precambrian and Quaternary parent materials. Plinthite and ironstone are found in the strongly weathered soils of the eastern part of the country. About $75 \%$ of the soils are acid with pH below 5.5 (Beenart, 1999). Soil acidity includes high exchangeable Al and possible Al toxicity for sensitive crops. Plant growth and production on these soils is limited by increasing depletion of $\mathrm{N}, \mathrm{P}, \mathrm{Ca}$ and $\mathrm{Mg}$, high $\mathrm{P}$ adsorption (1,500 to 3,000 $\mathrm{mg} \mathrm{kg}^{-1}$ of soil), low permanent charges (- 0.5 to $-2.45 \mathrm{cmol}^{+} \mathrm{kg}^{-1}$ ) and Al toxicity. Generally, soil organic carbon is low with the exception of soils in the valley swamps and forests where the $C$ concentrations may exceed $10 \%$. Most volcanic soils and soils under natural forests (e.g. Nyungwe forest, Gishwati forest) are high in N; soils with $\mathrm{N}$ deficiency are mostly found in the central and southern parts of the country. Phosphorus is the main element which limits crop yield in most soils, but particular in the soils derived from volcanic deposits (Mutwewingabo, 1989). About $87 \%$ of the soils have $\mathrm{pH}<5.2$ and are $\mathrm{P}$ deficient $(\mathrm{P}<30 \mathrm{mg}$ $\mathrm{kg}^{-1}$ of soil) (Mukuralinda, 2007).

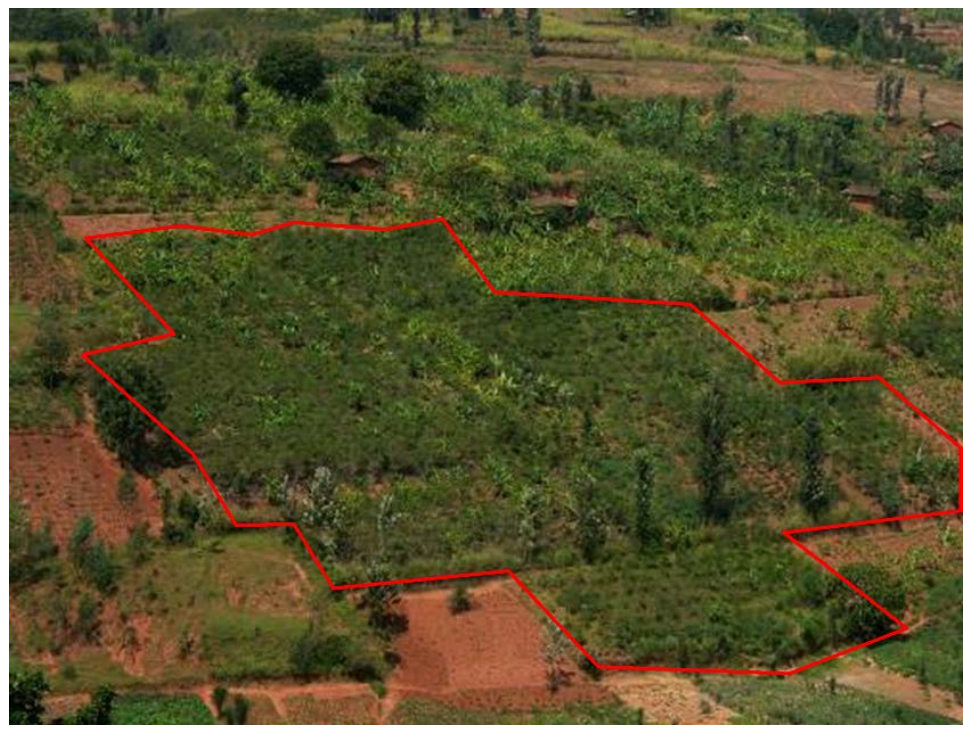

Photo 2.1 Scattered coffee fields partly intercropped with banana and surrounded by cultivated banana and annual crop fields, Kiribizi Sector, Nyamagabe District, Southern Province 


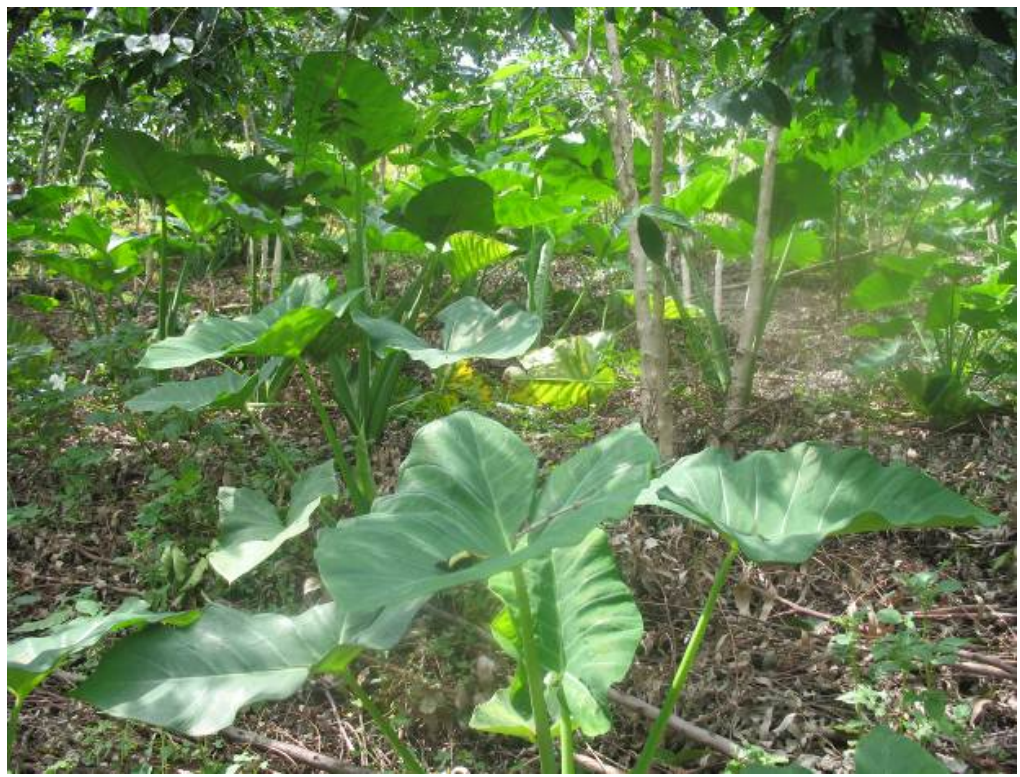

Photo 2.2 Coffee fields intercropped with taro, Kiribizi Sector, Nyamagabe District, Southern Province

Soils under coffee farming systems are characterized by very low $\mathrm{pH}$ values $(<5.0)$ with high soil aluminium toxicity (>30\%), very low Ca (<30\%), Mg (<10\%), N (<0.16\%), P (<20ppm), K $(<5.8 \%), S(<20 \mathrm{ppm}), \mathrm{Zn}(<1 \mathrm{ppm})$ and Bo (<0.8ppm) (Cordingley, 2009). A high aluminium toxicity level reduces root development and limits crop yield through reduced nutrient and water uptake. Calcium and magnesium deficiencies are common in most coffee farming systems throughout the country due to high aluminium toxicity in acid soils, covering the majority of the Rwandan soils. Besides, removal of crop residues after harvest is a common farming practice and it is a major cause of nutrient loss. Crop residues are mostly high in $\mathrm{K}$ and grains are high in $\mathrm{P}$. By removing residues and $\mathrm{K}$ and $\mathrm{P}$ deficiencies gradually develop (Yamoah et al., 1990).

\subsection{Coffee farming systems}

In Rwanda, coffee is grown by smallholders. Farming systems are mainly characterized by land fragmentation with many small plots that are scattered on hillsides (Photo 2.1). Depending on the number of trees per plots, farmers own between two and more than six plots. The scattered plots and the distance from home to the plots reduce the frequency of plant and land management practices. The Ministry of Agriculture and Animal Resources has adopted and is implementing a land consolidation policy aiming at re-organizing the land use patterns. Although the coffee farmers are encouraged to adopt a monoculture 
farming system, the intercropping farming system is mostly used because of land scarcity and land pressure. A coffee field often includes food and cash crops like banana, sweet potato, taro, cassava, yam, beans, cow-pea, horse grams (Photo 2.1 and 2.2). The cultivation of these crops between rows of coffee plants enables farmers to achieve a better combination of food and cash crops. It may also result in competition for water, nutrients and light, leading to reduced coffee growth and low coffee yields.

In Burundi, Uganda, Tanzania, Western Kenya, and Eastern Democratic Republic of Congo (DRC), coffee is sometimes grown in association with agroforestry (AF) tree species. The AF tree species that are preferred in coffee farming systems include Leucaena Leucocephala, Calliadra Callostrus, Tephrosia Vogerii, and banana (Boffa et al., 2009). In such systems, N fixing trees that are intercropped with coffee are pruned regularly to moderate the shade levels and maintain an adequate coffee productivity. The use of $\mathrm{N}$-fixing trees can increase litter decomposition, and $\mathrm{N}$ availability (Mafongoya and Nair, 1997) and may increase soil organic matter through tree biomass, which helps to stabilize soils against erosion, reduce soil disturbance, and improve soil chemical and physical properties (Mulumba and Lal, 2008). As many of the soils under coffee in Rwanda are characterized by $\mathrm{N}$ deficiency and high Al toxicity, farmers could benefit by adopting the agroforestry coffee farming systems, as the system could improve the coffee productivity.

Banana as shade-tree in coffee farming is not widely used in Rwanda, contrary to Uganda and Kenya where banana is a primary food and cash crop produced throughout the year. The use of banana as interplanted crop in coffee farming can contribute to increase coffee yields (Vaast et al., 2005) and no significant differences have also been reported between mono-cropped coffee and coffee-banana intercropping systems (Van Asten et al., 2011) (Table 2.1).

Table 2.1 Yields (means and sd) of mono-cropped and intercropped coffee ( $\mathrm{t}$ of green bean ha-1 $\mathrm{yr}^{-1}$ ) and banana ( $\mathrm{t}$ of fresh fruit ha-1 $\mathrm{yr}^{-1}$ ) in Uganda (After Van Asten et al., 2011)

\begin{tabular}{ccc}
\hline Cropping system & & Yield \\
Coffee mono-crops & Arabica coffee & Banana \\
\hline Coffee - banana intercrops & $1.23 \pm 0.88 \mathrm{a}$ & - \\
Banana mono-crops & $1.18 \pm 0.99 \mathrm{a}$ & $20.19 \pm 10.25 \mathrm{a}$ \\
\end{tabular}

N.B. For each parameter, values in the same column with the same letter are not statistically different.

In Rwanda coffee is mainly cultivated without shade, whereas in other part of the World mainly in Central America countries, coffee is cultivated under shade (Van Oijen et al., 
2010). Coffee production without shade can be as high as in shade systems (De Souza et al., 2012) provided inorganic fertilizers are applied. In Mexico small-scale coffee farmers prefer the shade system because it provides them with timber, firewood, and fruits (Peeters et al., 2003). It is often assumed that a coffee tree-shade system is beneficial ecologically as well as economically (Borkhataria et al., 2012a; Borkhataria et al., 2012b; Moguel and Toledo, 1999; Muschler, 2001; Staver et al., 2001; Vaast et al., 2005). However, a significant decrease of coffee yields has been reported in a high shade-tree density. Shade might be beneficial to reduce extremes in temperatures and rainfall, and regulate the fruit bearing, but in general it will give lower yields (De Graaff, 1986). Coffee without shade trees produces higher yields only if land and crop management systems, coffee varieties, altitude, and climatic conditions are considered. Unshaded coffee is more susceptible to failing harvests.

\subsection{Soil fertility management}

\subsubsection{Mulch}

Available mulches used in the coffee farming are from Eucalyptus branches (Photo 2.3), Grevillea branches, sorghum thatches, panicum spp., cympopogon spp., sugar cane leaves, banana leaves and mixed residues. Mulching is used as a soil conservation measure and it generally improved the soil (Photo 2.3 and 2.4) (Mutwewingabo, 1989). According to Romero et al. (2002), the increased nutrient concentrations in soils with mulches occur through direct leaching or decomposition. $\mathrm{N}$ and $\mathrm{K}$ can be provided to the soil directly by mulching and/or organic fertilization. About 10 to 25 tons of mulch per ha (a layer of \pm 10 $\mathrm{cm}$ ) can be used in coffee farming to provide $110 \mathrm{~kg}$ of N, $1200 \mathrm{~kg}$ of K, $18 \mathrm{~kg}$ of Ca, and 30 $\mathrm{kg}$ of $\mathrm{Mg}$ per ha, depending on type of mulch (Coste, 1989). Foshee et al. (1999) reported that straw mulch markedly increased $\mathrm{K}$ concentrations in tree farming. Hay mulch used as groundcover in orchards increased topsoil nitrate $\left(\mathrm{NO}_{3}\right), \mathrm{K}$, and $\mathrm{Mg}$ concentrations (Merwin et al., 1995). The application of mulch in coffee farming systems increases the content of soil organic matter and increases soil aggregate stability. Mulch availability is limited and but improvements in coffee production have been reported when applying mulch. Most farmers know the benefits of applying mulch but apply low quantities because of cost and lack of labour. 


\subsubsection{Organic and chemical fertilizers}

Both organic and chemical fertilizers are used in coffee farming; organic fertilizers are usually prepared by mixing grasses, crop residues or animal manure in compost. Inorganic fertilizers that are used include NPK (20-10-10) applied at $400 \mathrm{~g}$ per tree per year, or NPK (17-17-17) at 120 g per tree per year plus urea ( $46 \%$ of $N$ ) at 75 g per tree per year. These chemical fertilizers have to be applied at two separate times (March and September) and at half dose to reduce the potential for leaching loss (Beenart, 1999).

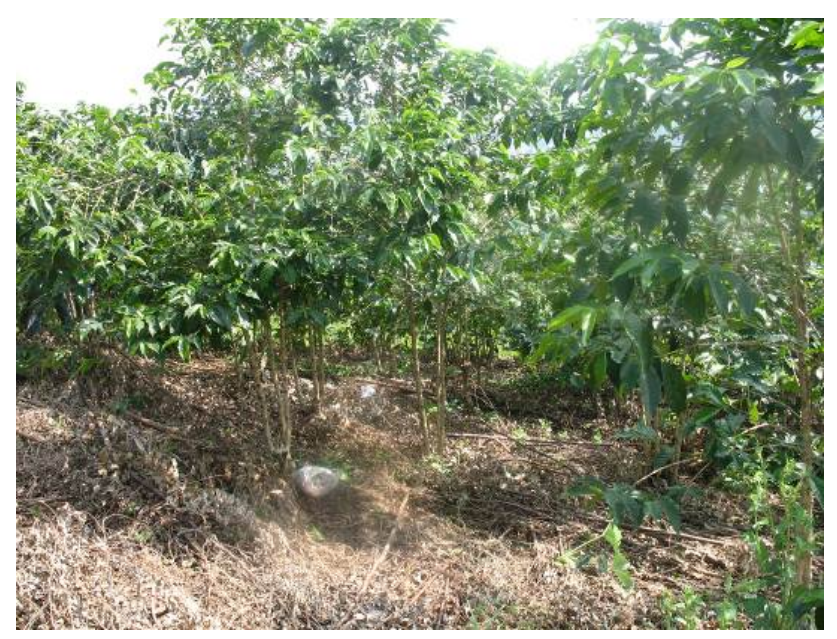

Photo 2.3 Coffee mulched with Eucalyptus leaves, Kiribizi Sector, Nyamagabe District, Southern Province

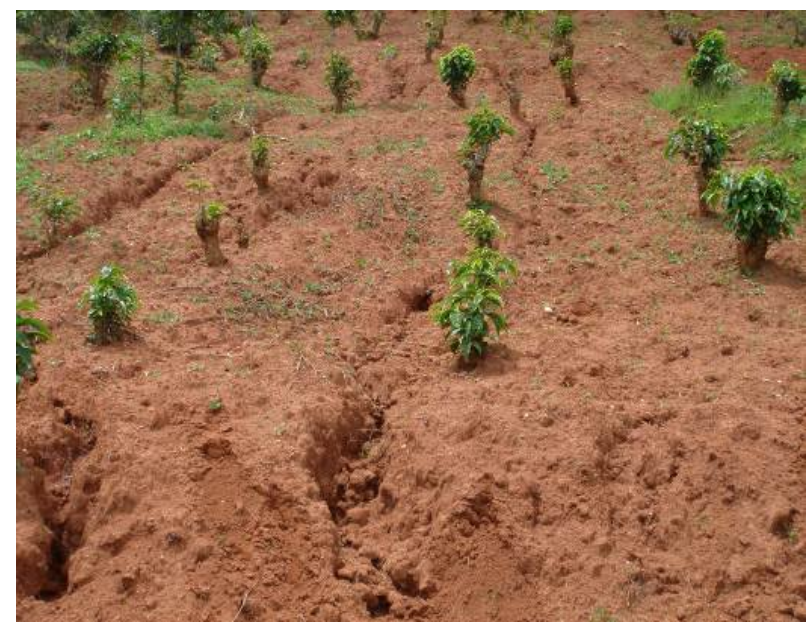

Photo 2.4 Heavily pruned back coffee causing lack of groundcover and severe soil erosion 
Depending on the coffee variety (Mibilizi, Catuai, Catimor, BM, Barrar, Jackson, Baraka), the agro-ecological conditions and soil and plant management, coffee yields vary between 0.8 and $2.8 \mathrm{t} \mathrm{ha}^{-1}$ of dry coffee beans (Loveridge and Nyarwaya, 2003). Yields above $2.8 \mathrm{t} \mathrm{ha} \mathrm{a}^{-1}$ of dry coffee are rare. In the Western part of the country soils are highly suitable for coffee and yields vary between 1.1 and $1.6 \mathrm{t} \mathrm{ha}^{-1}$. The central and southern areas are moderately suitable for coffee and the yield varies from 0.8 to $1.2 \mathrm{t} \mathrm{ha}^{-1}$ of dry coffee. Coffee yield in the Eastern region is low, averaging $1.0 \mathrm{t} \mathrm{ha}^{-1} \mathrm{y}^{-1}$. Potassium deficiency impacts coffee yields, especially the size of the berries. Potassium deficiency is mainly observed in acidic soils developed on shale parent material (Cordingley, 2009). Nitrogen deficiency is often observed on degraded soils and poorly managed soils. The $\mathrm{N}$ deficiency in coffee farming has the largest influence on vegetative development, leading to a reduced photosynthetic potential (Cordingley, 2009). Phosphorus (P) is required in smaller amounts compared to $\mathrm{N}$ and $\mathrm{K}$. Both $\mathrm{P}$ and $\mathrm{K}$ are required to stimulate coffee growth of young trees. In mature trees, $P$ is required to play the role in flower development, and thus improve yield (Gloria, 2002). Low level of P could affect the size of the coffee beans (Cordingley, 2009). Thus the key elements for high yielding coffee are $\mathrm{N}$ and $\mathrm{K}$ although but for higher yields, a well-balanced $\mathrm{N}-\mathrm{P}-\mathrm{K}$ fertilizer application is required.

The use of chemical fertilizer alone is not always effective when the soil is low in organic matter. In the southern part of Rwanda on gravelly Oxisols that are low in organic matter content, the use of NPK (20-10-10) yielded around $0.32 \mathrm{~kg}$ of dry beans per tree per year (0.8 $\mathrm{t} \mathrm{ha}^{-1}$ ) (Mukashema, 2003). Organic fertilizers are applied in order to increase the physical properties of the soil and its nutrient holding capacity. On the very acid soils of Rwanda, $\mathrm{Ca}$ and $\mathrm{Mg}$ are applied every three years by applying $1 \mathrm{~kg}$ of lime/travertine per tree to decrease the soil acidity (Beenart, 1999).

\subsection{Soil Erosion and Soil Conservation}

Rwanda has many high mountains and steep-sloping hills and much of the farmland suffers from moderate to severe soil erosion. Maximum soil loss has been estimated at $557 \mathrm{tha}$ $\mathrm{yr}^{-1}$ (MINITERE, 2003). In the Southern province, Butare, on a 28 to $55 \%$ slope, where traditional agricultural practices were used, soil losses were reported to be about 250 t ha${ }^{1} \mathrm{yr}^{-1}$ (Konig, 1992). Lewis and Nyamulinda (1996) reported values up to $270 \mathrm{t} \mathrm{ha}^{-1} \mathrm{yr}^{-1}$ on a $60 \%$ slope without any vegetation. Measurements on runoff plots have shown that sheet and rill erosion can reach 300 to 700 tons $\mathrm{ha}^{-1} \mathrm{yr}^{-1}$ on 20 to $60 \%$ slopes with regional rainfall erosivity - $\mathrm{R}$ varying between 250 and 700 , and soil erodibility - $K$ varying between 0.001 and 0.20 (Roose and Ndayizigiye, 1997). These values are very high, and found in fields without soil conservation techniques like mulching or terracing. 
With little natural mulch formed by litter, considerable soil erosion losses have been observed in coffee plantations (Hartemink, 2005). Ataroff and Monasterio (1997) reported larger soil erosion losses in unshaded coffee plantations $\left(1.57 \mathrm{t} \mathrm{ha}^{-1} \mathrm{y}^{-1}\right)$ compared to shade coffee $\left(0.73 \mathrm{t} \mathrm{ha}^{-1} \mathrm{y}^{-1}\right)$. Studies in Colombia, Venezuela and Indonesia on runoff plots measured soil losses ranging from 0.2 to $8.9 \mathrm{t} \mathrm{ha}^{-1} \mathrm{y}^{-1}$ in established coffee plantations (lijima et al., 2003). Assuming a crop factor $-\mathrm{C}=0.415$ for coffee, and using the USLE model, Angima et al. (2003) reported soil losses of 112 to $290 \mathrm{t} \mathrm{ha}^{-1} \mathrm{yr}^{-1}$ under coffee. These values are much lower compared to the actual erosion rates in Rwanda. Mulching significantly reduce soil erosion (Lewis, 1988). In Rwanda, with $20 \mathrm{t} \mathrm{ha}^{-1} \mathrm{y}^{-1}$ of mulch in coffee plantations, erosion is reduced to less 1 ton ha ${ }^{-1} \mathrm{y}^{-1}$ (Roose and Ndayizigiye, 1997).

Table 2.2 The $\mathrm{N}, \mathrm{P}_{2} \mathrm{O}_{5}$ and $\mathrm{K}_{2} \mathrm{O}$ balance in two different settings in Rwanda (Stoorvogel and Smaling, 1990)

\begin{tabular}{ccccccccc}
\hline & $\begin{array}{c}\text { Deposition } \\
(+)\end{array}$ & $\begin{array}{c}\text { Fixation } \\
(+)\end{array}$ & $\begin{array}{c}\text { Production } \\
(-)\end{array}$ & $\begin{array}{c}\text { Residues } \\
(-)\end{array}$ & $\begin{array}{c}\text { Leaching } \\
(-)\end{array}$ & $\begin{array}{c}\text { Gaseous } \\
\text { losses }(-)\end{array}$ & $\begin{array}{c}\text { Erosion } \\
(-)\end{array}$ & $\begin{array}{c}\text { Total } \\
(\mathrm{kg} / \mathrm{ha})\end{array}$ \\
\hline $1(\mathrm{~N})^{*}$ & 4 & 2 & 28 & 0 & 2 & 7 & 5 & -36 \\
$2(\mathrm{~N})^{*}$ & 5 & 5 & 28 & 1 & 4 & 14 & 30 & -67 \\
$1\left(\mathrm{P}_{2} \mathrm{O}_{5}\right)$ & 2 & 0 & 5 & 1 & 0 & 0 & 2 & -6 \\
$2\left(\mathrm{P}_{2} \mathrm{O}_{5}\right)$ & 2 & 0 & 5 & 1 & 0 & 0 & 11 & -15 \\
$1\left(\mathrm{~K}_{2} \mathrm{O}\right)$ & 3 & 0 & 16 & 1 & 1 & 0 & 4 & -19 \\
$2\left(\mathrm{~K}_{2} \mathrm{O}\right)$ & 4 & 0 & 16 & 2 & 6 & 0 & 23 & -43 \\
\hline
\end{tabular}

$*_{1}=$ No fertilizer, no manure, residue removing of $10 \%$ and erosion of $5 \mathrm{t} \mathrm{ha}^{-1} \mathrm{yr}^{-1}$.

$2=$ No fertilizer, no manure, residue removing of $20 \%$ and erosion of $15 \mathrm{t} \mathrm{ha}^{-1} \mathrm{yr}^{-1}$.

Soil erosion also means nutrient losses. Table 2.2 gives an indication of the nutrients that are lost in one production year on coffee fields in Rwanda assuming a soil erosion rate of 15 $\mathrm{t} \mathrm{ha}^{-1} \mathrm{yr}^{-1}$. This will lead to a deficit of nutrients, and consequently, a decrease in coffee yield. Soil erosion takes up about $50 \%$ of all the nutrient losses (Stoorvogel and Smaling, 1990).

Soil conservation includes erosion control measures (e.g. bench terraces, sloping or progressive terraces, and ditches), and soil management like application of organic fertilizers such as manure and compost, application of inorganic fertilizers, liming, mulching, agroforestry, and crop rotations. The physical measures include trenches or ditches, progressive terraces using grass or vegetation strips, soil bunds, bench or radical terraces, and narrow bench terraces. Radical/bench terraces improve water retention, soil nutrients (Fleskens, 2007), and increase crop yields (Kriegl and Preissler, 1987). However, farmers often mention the high labor cost that is required to maintain them (Bizoza and Graaff, 2012). 


\subsection{Discussion and Conclusions}

Coffee is important for the Rwanda economy and for the livelihood of many of his farmers. The government has set in place a series of policies to stimulate more efficient and higher yielding coffee production. These policies only become effective if the soil resource and soil management is taken in full account.

Generally, coffee is cultivated as a pure stand commercial crop or monoculture farming. Intercropping is common because of limited cultivable land for annual cropping. Coffee intercropping with food crops will increase the competition for nutrients, light and water, and thus affects the coffee yield. Although the intercropping practice does not leave the soil surface bare, it may contribute to control erosion, mainly for the coffee cultivated on marginal land like the steep slopes of the upper hillsides. The removal of crop residues together with the coffee litter can be used as mulch to control water erosion, but also to improve the soil physical and chemical properties. In addition, to control water erosion, the coffee farmers used various management practices, including mechanical man-made trenches, hedge-rows, mulching, or a combination of the mechanical and biological methods. Mulching in coffee farming remains the dominant management practice used to control erosion and weeds control. In addition to the use of the sustainable land management technologies, considerable focus should also be directed towards farmers' training and awareness creation through participatory extension methods, like farmer field schools (FFS).

Organic fertilization (with manure, composted coffee pulp, etc.) and lime should be promoted at large scale as these are at the heart of sustainable soil management practices. Such applications maintain and build soil carbon level, and may supply nutrients in a wellbalanced ratio. Liming will ensure that the soil $\mathrm{pH}$ is within the optimum range for soil microbial activity, which will correct the high aluminium toxicity and thus improve the efficiency of nutrient uptake. In most Rwandan soils, a supply of $50-60 \%$ Ca and $10-16 \%$ $\mathrm{Mg}$ is recommended to stimulate the soil biological activity (Cordingley, 2009). The adoption of organic and liming applications in coffee farming systems could reduce the input of mineral fertilizers required to achieve higher yields.

In order to promote organic fertilizer use in coffee farming, the government invested in sensitization and mobilization of farmers. In 2011, 3055 tons of organic fertilizers were applied on around 11,000 ha of coffee (Mafongoya and Nair, 1997). The application of mineral fertilizers in coffee farming is but the lack of sufficient farmer awareness of the value of applying mineral fertilizers limits coffee productivity. The $20-10-10 \mathrm{~N}-\mathrm{P}-\mathrm{K}$ fertilizer is used in coffee farming, but it is essential to apply fertilizers close to $1: 1$ ratio of 
$\mathrm{N}$ : $\mathrm{K}$ in soils with low $\mathrm{K}$ content (Cordingley, 2009). For 2012, the government targets to use up to 4,000 tons of mineral fertilizers on 35,000 ha of planted coffee, with an investment cost of USD\$2,9 million for mineral fertilizers (NAEB, 2012). The above investment cost could only be recovered if the current coffee productivity is improved up to 7.5 tons per ha (NAEB, 2012).

The Government encourages the farmers to join the land consolidation programme, whereby coffee can even be cultivated as "Ibiterane", meaning larger coffee plantations. The programme aims at putting together the smalholder farms that are next to each other in order to get a big property that can be used particularly as a pure monoculture farming system. Thus, the land consolidation programme envisages increasing coffee production, as for other annual crops, by encouraging farmers to join their coffee farms. Farmers are expected to obtain a high coffee production of a good quality that will generate income, and will thus contribute to poverty reduction for the rural population.

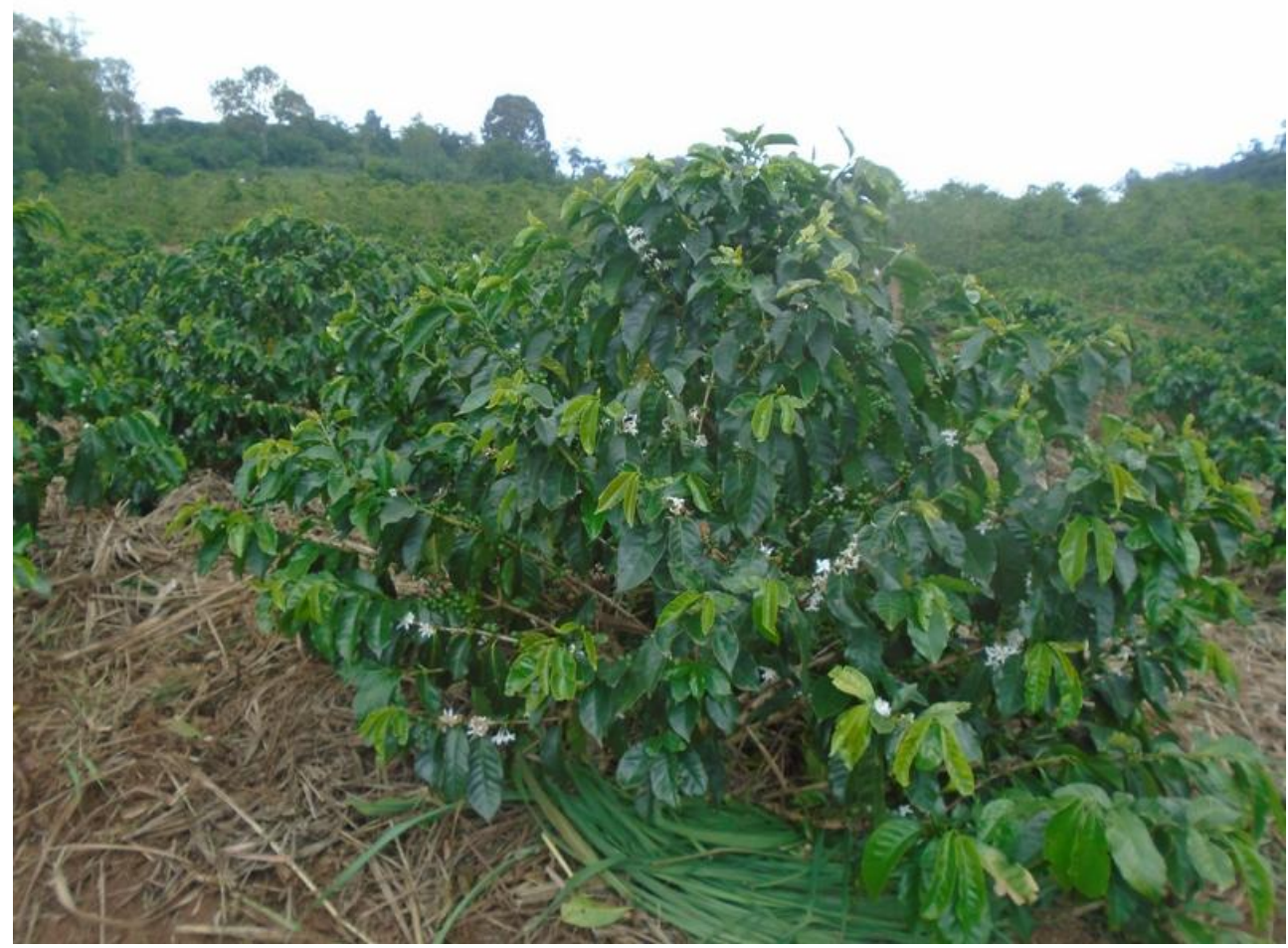




\section{GIS-based multi-criteria analysis for Arabica coffee expansion in Rwanda}

The Government of Rwanda is implementing policies to increase the area of Arabica coffee production. Information on the suitable areas for sustainably growing Arabica coffee is still scarce. This study aimed to analyze suitable areas for Arabica coffee production. We analyzed the spatial distribution of actual and potential production zones for Arabica coffee, their productivity levels and predicted potential yields. We used a geographic information system (GIS) for a weighted overlay analysis to assess the major production zones of Arabica coffee and their qualitative productivity indices. Actual coffee yields were measured in the field and were used to assess potential productivity zones and yields using ordinary kriging with ArcGIS software. The production of coffee covers about 32000 ha, or $2.3 \%$ of all cultivated land in the country. The major zones of production are the Kivu Lake Borders, Central Plateau, Eastern Plateau, and Mayaga agro-ecological zones, where coffee is mainly cultivated on moderate slopes. In the highlands, coffee is grown on steep slopes that can exceed $55 \%$. About $21 \%$ percent of the country has a moderate yield potential, ranging between 1.0 and $1.6 t$ coffee $h a^{-1}$, and $70 \%$ has a low yield potential $\left(<1.0\right.$ t coffee $\left.h^{-1}\right)$. Only 9\% of the country has a high yield potential of 1.6 to 2.4 t coffee $h^{-1}$. Those areas are found near Lake Kivu where the dominant soil Orders are Inceptisols and Ultisols. Moderate yield potential is found in the Birunga (volcano), Congo-Nile watershed Divide, Impala and Imbo zones. Low-yield regions ( $<1 t h a^{-1}$ ) occur in the eastern semi-dry lowlands, Central Plateau, Eastern Plateau, Buberuka Highlands, and Mayaga zones. The weighted overlay analysis and ordinary kriging indicated a large spatial variability of potential productivity indices. Increasing the area and productivity of coffee in Rwanda thus has considerable potential.

Based on: Innocent Nzeyimana, Alfred E. Hartemink, Violette Geissen. 2014. GIS-based multi-criteria analysis for Arabica coffee expansion in Rwanda. PLoS ONE 9 (10): e107449. 


\subsection{Introduction}

Coffee is one of the most important tradable commodities in the world and a major foreignexchange earner in many developing countries (Ponte, 2002). Arabica coffee accounts for two-thirds of the global coffee market (Labouisse et al., 2008). Coffee is a top export commodity and an important source of revenue in Eastern and Central African countries (FAO, 2014). In some of these countries, such as Burundi, Uganda, Tanzania, Kenya, and the Democratic Republic of Congo, coffee is occasionally grown in association with agroforestry tree species for nitrogen fixation (Boffa et al., 2009).

Rwanda produces mainly Arabica coffee, largely cultivated by smallholder farmers as monocrop on plots of less than a hectare scattered on hilly slopes. In South and Central America, coffee is mostly grown on large monoculture plantations or under shade (Van Oijen et al., 2010). In Rwanda, coffee is predominantly grown along the shores of Lake Kivu in the west, on the plateau in the central part of Rwanda, and in the Mayaga region in the east (Nzeyimana et al., 2013). Rwanda has ten agro-ecological zones: Imbo, Impara, Kivu Lake Borders, Birunga (volcano), Congo-Nile Watershed Divide, Buberuka Highlands, Central Plateau, Mayaga-Bugesera, Eastern Plateau, and Eastern Savanna. Details of the characteristics of the Rwandan agro-ecological zones can be found in (Verdoodt and Van Ranst, 2003).

The total area of arable and permanently cropped land in Rwanda is about 1.45 million ha (FAO, 2014), of which about 30,000 ha was under coffee production in 2005 and it increased to 41,762 ha in 2012 (FAO, 2014). The total area under coffee production in the tropics is about 10.6 million ha (Clay, 2004). The expansion of land for the production of coffee depends on three main factors: environmental conditions (e.g. topography, soil type, climate, and elevation), practices of agricultural land management, and genetic resources (i.e. coffee varieties) (Bosselmann et al., 2009). The growing conditions for Arabica coffee in Rwanda are characterized by an altitude of 1,400-1,900 $\mathrm{m}$ a.s.l., an annual rainfall of 1,500-1,600 mm, temperatures of $18-22{ }^{\circ} \mathrm{C}$, and an average amount of sunlight of 2,2002,400 hours per year. Arabica coffee also requires fine-textured soils of at least one-meter with total porosities of $50-60 \%$, a pH of $4.5-6.0$, moderate to high sums of basic cations, and 2-5\% organic matter (Verdoodt and Van Ranst, 2003).

In Rwanda, as in other developing countries, coffee farming is reserved for steep slopes and soils with low fertility (Nzeyimana et al., 2013). Most of these lands have been degraded by soil erosion and are under pressure from intensive cropping by smallholder farmers. Fertile soils are usually reserved for growing staple food crops, which restricts coffee growing to soils of low fertility. In Rwanda, coffee yields above $2.8 \mathrm{t} \mathrm{ha}^{-1}$ are rare (Nzeyimana et al., 
2013). The Government of Rwanda has developed a set of policies for improving farmer livelihoods through an increase of sustainable coffee cultivation. A study of agricultural development in Africa has shown that successes are often linked to a cash-crop component and that food crops will profit as a consequence of improved cash income (Gabre-Madhin and Haggblade, 2004). The identification of potential production zones for expanding coffee production and the prediction of coffee yields are needed to effectively implement these policies.

The evaluation of land is an essential procedure to assess opportunities, potentials, and limitations that a given parcel land can offer for agricultural purposes (Rossiter, 1996). Various approaches of land evaluation with specific methodology have been developed to study land-use suitability (FAO, 1976; Rossiter, 1996). Geographic information systems (GISs) have been used for mapping and analyzing land-use suitability (Malczewski, 2004). Various GIS-based models have been developed by various researchers for land-use planning and suitability analysis (Coleman and Galbraith, 2000; De La Rosa et al., 1992; Joerin et al., 2001; Li et al., 2012; Maji et al., 1998; Maji et al., 2001; Malczewski, 2004; Walke et al., 2012). The GIS-based models use geo-spatial and geo-statistical tools to assess the land units and to present the results as suitability maps. The models use multi-criteria evaluative approaches and methods by weights, values, or intensities of preference (Malczewski, 2004; Malczewski, 1996). Weighted overlay analysis is one such approach of GIS modeling using spatial multi-criteria evaluation (ESRI, 2011; Janssen and Rietveld, 1990). The objectives of this study were: (a) to analyze the spatial distribution of potential production zones for Arabica coffee production and the current productivity levels in the various zones; and (b) to predict potential coffee yields and identify potential productivity zones. To achieve the objectives, we developed a model of land evaluation for expanding the production of Arabica coffee in Rwanda based on standard methodologies for land evaluation and geo-spatial analysis.

\subsection{Material and methods}

\subsubsection{Data acquisition}

Digitized and tabulated data were assembled for the entire country, including 43 digital soil maps (scale 1:50,000), a digital elevation model (Shuttle Radar Topography Mission (SRTM) at $90 \times 90 \mathrm{~m}$ resolution), the coffee production database for 2005 , general and administrative maps (2006 versions, scale 1:50,000), and a digital agro-climatic database containing temperatures, rainfall, altitudes, and agro-climatic zones. The database contained the amount of coffee produced and the number of trees in each administrative 
sector. Each sector was divided into cells, which are the lowest administrative units within the Republic of Rwanda.

\subsubsection{Data processing: analysis of potential zones for coffee production}

The methodology consisted of collecting (on a national scale) data such as soil type and slope gradient and analyzing the spatial distribution of coffee using the spatial-analysis toolset of the ArCGIS software (ESRI, 2001). The methodology aimed at identifying the major production zones based on soil and slope types. The combination of data for coffee distribution and soil was used for identifying the dominant soil types on which coffee is mainly produced and then for estimating the area coverage. The combination of data for coffee distribution and slope was for identifying the dominant slope types on which coffee is mainly produced and then for estimating the area coverage. The spatial distribution of coffee was identified, potential coffee production zones were characterized, and the sizes of the areas of coffee per slope and soil type in the various agro-ecological zones were estimated.

\subsubsection{Multi-criteria analysis to estimate a qualitative Arabica coffee productivity index}

The assessment of qualitative productivity indices for coffee essentially required the development of a GIS-based database for the optimal use of land resources for coffee. A geo-spatial database of data for elevation, slope, soil parameters, and rainfall and temperature extracted from the digital agro-climatic database, was generated in a GIS multi-criteria model (Fig. 3.1). The landscape characteristics, climatic conditions, and soil parameters of a specific site are the most important determinants of land suitability (Coleman and Galbraith, 2000). The upper part of the flow chart in Figure 3.1 was thus used to analyze the qualitative productivity indices to indicate the level of productivity in the various agro-ecological zones. The multi-criteria model combined the different layers of data (i.e. elevation, slope, soil parameters, rainfall, and temperature) to identify the major production zones and their current productivity index (CPI). Data for photo synthetically active radiation were not available and so were not included in the model. The multi-criteria analysis used each input raster as a decision variable for sequential GIS interactions between layers. Data were processed using the spatial-analysis tools of ArcGIS (ESRI, 2011, 2001). The geo-spatial analysis then allowed the combination of the input rasters using weighted overlay analysis in the Model Builder component of ArcGIS to generate output rasters. Each cell value in each input raster was assigned a new, reclassified score value on 
an evaluation scale of 1 to 5 , where 1 represents the lowest suitability and 5 the highest (i.e. scoring of the Arabica coffee requirements over others based on their importance as guided by FAO (1976). Each of the new reclassified score was then weighted by assigning a percentage influence value (i.e. $100,75,50,25$, or $0 \%$ ) (Table 3.1). This is achieved by multiplying the cell values (i.e. the new reclassified scores) by their percentage influence, and the results are added together to create the output raster. The new output-raster indices were then used as qualitative productivity indices. The weighted $Z$ matrix can have the following form when $m$ input factors and $n$ criteria are considered:

$$
Z=\left[\begin{array}{ccccccc}
x_{01} & \cdot & \cdot & x_{0 j} & \cdot & \cdot & x_{0 n} \\
\cdot & \cdot & \cdot & \cdot & \cdot & \cdot & \cdot \\
\cdot & \cdot & \cdot & \cdot & \cdot & \cdot & \cdot \\
x_{i 1} & \cdot & \cdot & x_{i j} & \cdot & \cdot & x_{i n} \\
\cdot & \cdot & \cdot & \cdot & \cdot & \cdot & \cdot \\
\cdot & \cdot & \cdot & \cdot & \cdot & \cdot & \cdot \\
x_{m 1} & \cdot & \cdot & x_{m j} & \cdot & \cdot & x_{m n}
\end{array}\right]
$$

where $Z$ is the combined-factor weighted matrix, $m$ is the number of input factors, $n$ is the number of criteria describing each input factor, $x_{i j}$ is the score representing the level of importance of input factor $i$ based on criterion set $j$ of the Arabica coffee requirements. The score $x_{i j}$ is assigned a percentage influence value according to the importance of the environmental coffee productivity factor within a single input raster as illustrated in Table 3.1 (ESRI, 2011).

The combination of the output rasters is for understanding the influence of the combined environmental factors and/or each factor separately on coffee productivity. The highproductivity class has no significant limitations for sustainable coffee production. The moderate class is characterized by altitudes of 1,200-1,400 m, annual rainfall below $900 \mathrm{~mm}$ or above $2,000 \mathrm{~mm}$, and temperatures varying between 18 and $21{ }^{\circ} \mathrm{C}$. The low class is characterized by altitudes below 1,200 or above $2,000 \mathrm{~m}$, annual rainfall below 800 or above $2,000 \mathrm{~mm}$, and temperatures below 10 or above $30{ }^{\circ} \mathrm{C}$ (FAO, 1976; Verdoodt and Van Ranst, 2003). 


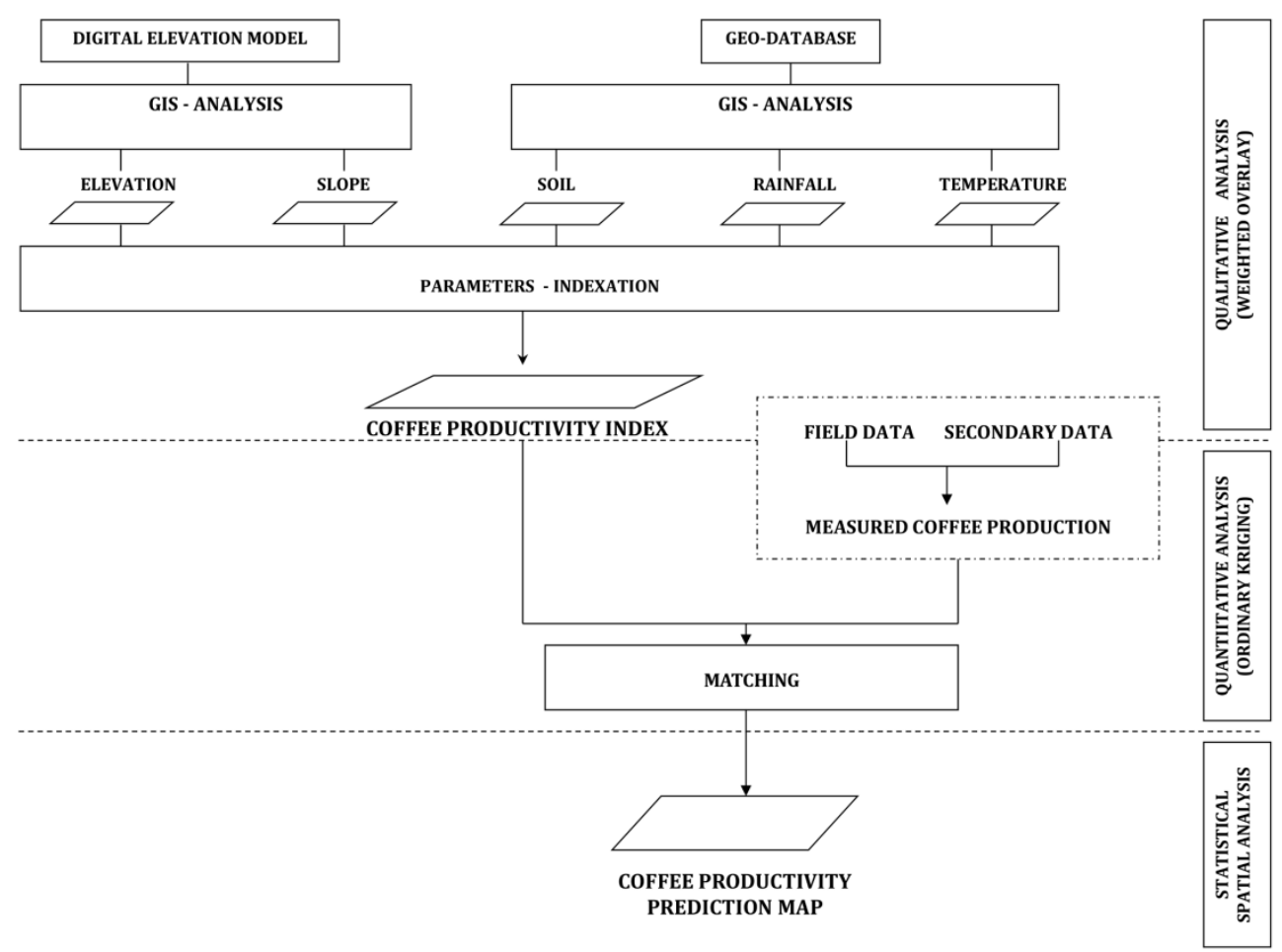

Figure 3.1 Flow chart of the methodology used to derive coffee productivity indices and predicted Arabica coffee yields.

\subsubsection{Multi-criteria analysis to estimate the quantitative Arabica coffee productivity index}

The qualitative productivity indices (low, moderate, and high) were then quantified with actual yields to generate quantitative Arabica coffee productivity indices using ordinary kriging. The qualitative indices were extrapolated to 121 sampled sites of actual Arabica coffee yields measured at various sites countrywide.

\subsubsection{Actual Arabica coffee yield}

Actual yields were collected at 121 farms countrywide. Smallholder coffee fields, particularly those near a coffee-washing station, were selected and monitored for yield. The coffee fields are private farms owned by smallholder farmers, technically supported by the National Agricultural Export Development Board (NAEB). In collaboration with the NAEB, 
the identified farmers participated voluntary in the selection of sample fields. No specific permissions were required for the field activities. In addition, the field studies did not involve any endangered or protected species.

Table 3.1 Weighted environmental criteria for evaluating the qualitative Arabica coffee productivity classes and scores (1 to 5 for worst to best) ${ }^{a}$

\begin{tabular}{|c|c|c|c|c|c|c|c|}
\hline \multicolumn{5}{|c|}{ Environmental coffee productivity criteria } & \multirow[b]{2}{*}{$\begin{array}{c}\text { Qualitative } \\
\text { productivity } \\
\text { class }\end{array}$} & \multirow[b]{2}{*}{$\begin{array}{l}\text { Influence } \\
\left.\text { value }^{\text {c }} \%\right)\end{array}$} & \multirow[b]{2}{*}{ Score $^{d}$} \\
\hline $\begin{array}{l}\text { Elevation } \\
(\mathrm{m})\end{array}$ & Rainfall (mm) & $\begin{array}{c}\text { Temp. } \\
\left({ }^{\circ} \mathrm{C}\right)\end{array}$ & Soil type ${ }^{b}$ & $\begin{array}{c}\text { Slope } \\
(\%)\end{array}$ & & & \\
\hline $1600-1800$ & $1400-1600$ & $18-20$ & $\begin{array}{c}\text { MOLL, } \\
\text { AND }\end{array}$ & $0-4$ & Very high & 100 & 5 \\
\hline $1400-1600$ & $1200-1400$ & $16-18$ & ALF & $4-12$ & High & 75 & 4 \\
\hline $1800-2000$ & $1600-1800$ & $20-22$ & & & & & \\
\hline $1200-1400$ & $\begin{array}{l}1000-1200 \\
1800-2000\end{array}$ & $\begin{array}{l}15-16 \\
22-24\end{array}$ & $\begin{array}{c}\text { INCEPT, } \\
\text { ULT }\end{array}$ & $12-25$ & Moderate & 50 & 3 \\
\hline $\begin{array}{c}1000-1200 \\
>2000\end{array}$ & $\begin{array}{c}800-1000 \\
>2000\end{array}$ & $\begin{array}{l}14-15 \\
24-26\end{array}$ & OX, ENT & $25-50$ & Low & 25 & 2 \\
\hline$<1000$ & $<800$ & $\begin{array}{l}<14 \\
>26\end{array}$ & $\begin{array}{l}\text { HIST, } \\
\text { VERT }\end{array}$ & $>50$ & Very low & 0 & 1 \\
\hline
\end{tabular}

a The table is a combination matrix that shows the level of productivity if we consider environmental productivity criteria of Arabica coffee production, as guided by FAO (1976).

${ }^{b}$ AND, Andisols; ALF, Alfisols; ENT, Entisols; INCEPT, Inceptisols; HIST, Histosols; MOLL, Mollisols; OX, Oxisols; ULT, Ultisols; VERT, Vertisols.

c The influence value represents the influence of the raster value compared to the other criteria as a percentage (i.e. $100,75,50,25$, or $0 \%$ ).

d Each cell value in each input raster was assigned a new, reclassified score value on an evaluation scale of 1 to 5 (where 5 represented the best score and 1 the worst score 1 ) The scoring of the environmental productivity criteria of coffee was based on their importance as guided by FAO (1976).

The yields were measured by sampling three branches of coffee trees (low, middle, and high branches) Experimental plots for data collection were approximately $10 \times 10 \mathrm{~m}$ and contained 25 coffee trees (i.e. 2,500 trees ha ${ }^{-1}$ ), each $2 \mathrm{~m}$ apart. The coffee trees were predominantly 20-25 years of age and were cropped as monocultures.

All sample sites were independently selected with equal probability. Five randomly selected trees in each plot were sampled by collecting a composite sample of $500 \mathrm{~g}$ of good berries from the three branches weekly from April to September 2009. The coffee berries were cleaned, oven-dried at $60^{\circ} \mathrm{C}$ for $48 \mathrm{~h}$, adjusted to $12 \%$ moisture content, and weighed. Grain yield was determined on each randomly selected tree, and a spatial mean plot yield was calculated as: 
$\bar{y}=\frac{1}{n} \sum_{i=1}^{n} y_{i}$

where $\bar{y}\left(\mathrm{t} \mathrm{ha}^{-1}\right)$ is the average yield for 2009, $\mathrm{yi}_{\mathrm{i}}\left(\mathrm{t} \mathrm{ha}^{-1}\right)$ is the yield at sample site $\mathrm{i}$, and $\mathrm{n}$ is the number of sample sites.

\subsubsection{Predicted Arabica coffee yield}

Ordinary kriging analysis was conducted to predict potential yields and to identify potential productivity zones for Arabica coffee (ESRI, 2011, 2001), based on actual yields measured at the study site. The ordinary kriging is one of the mostly used geo-statistical methods, quite efficient and accurate for spatial prediction and interpolation (Diggle and Ribeiro, 2007). The prediction of yield was based on the qualitative productivity indices validated over the actual yields. A variogram was estimated using Matheron's estimator (Genton, 2000, 1998):

$y^{\wedge}(h)=\frac{1}{2 M h} \sum_{i=1}^{M h}\left\{Z\left(x_{i}\right)-Z\left(x_{i}+h\right)\right\}^{2}$

where $Z\left(x_{i}\right)$ is the actual yield measured at the study site $\left(x_{i}\right), h$ is the lag, i.e. both distance and direction between the sample sites, $M_{h}$ is the pair of sample sites separated by lag $h$, and $\gamma^{\wedge}(h)$ is the semi-variance at lag $h$.

To assess the spatial correlation of the yields, prediction accuracy was calculated by comparing expected yields, $Z^{\wedge}\left(C Y I_{j}\right)$, with actual yields measured at the validation sites, $(n)$ - $\mathrm{Z}\left(\mathrm{CY}_{\mathrm{j}}\right)$, and to assess a systematic error, calculated as the mean prediction error (MPE) (Park and Vlek, 2002):

$M P E=\frac{1}{n} \sum_{j=1}^{1}\left[Z \wedge\left(C Y I_{j}\right)-Z\left(C Y I_{j}\right)\right]$

where $\mathrm{CYI}$ is the coffee yield index, $\mathrm{Z}^{\wedge}\left(\mathrm{CY}_{\mathrm{j}}\right)$ is the expected yield index generated from the qualitative analysis, and $Z\left(C Y I_{j}\right)$ is the actual yield measured at the validation sites $(n)$. The validation set accounted for 121 sample sites. The accuracy of prediction was calculated as a root mean square error (RMSE) of prediction (Park and Vlek, 2002):

$R M S E=\sqrt{\frac{1}{n}} \sum_{j=1}^{1}\left[Z \wedge\left(C Y I_{j}\right)-Z\left(C Y I_{j}\right)\right]^{2}$

The RMSE is a measure of fitness of the prediction curve; the smaller the RMSE, the better the prediction. Ordinary kriging uses and compares different fitting models that perform the analysis, reduce uncertainty, and produce the best prediction map. The RMSE is thus standardized by considering the total variance of the observed values and is then termed 
the root mean square standardized error (RMSSE) or the mean standardized error (MSE). The RMSSE and the MSE were estimated from the variances between the observed values, i.e. the actual yields measured at the study site (ESRI, 2011; Park and Vlek, 2002):

$$
R M S S E=\frac{\frac{1}{n} \sum_{j=1}^{1}\left[Z \wedge\left(C Y I_{j}\right)-Z\left(C Y I_{j}\right)\right]^{2}}{s^{2}}
$$

where $\mathrm{s}^{2}$ is the total variance of the CYI at the sample site.

A satisfactory accuracy of prediction has an MSE close to zero and an RMSSE close to unity (ESRI, 2011; Park and Vlek, 2002). If the RMSSE exceeds unity, the model underestimates the variability at the validation sites, and thus the prediction is unsatisfactory (ESRI, 2011; Hengl et al., 2004; Park and Vlek, 2002).

The normality of the measured yield data was determined with Kolmogorov-Smirnov test. All data were normally transformed to meet the assumption of normality by comparing different types of model fitting (exponential and Gaussian) for the analysis, and only the model with the smallest Akaike information criterion (AIC) was adopted. The AIC is a measure of how well a model fits the empirical data; the smaller the AIC, the better the fit (ESRI, 2011). In addition, cross-validation, comparing the predicted values with the measured values, checked the quality of the predicted values (Mueller et al., 2004).

\subsection{Results}

\subsubsection{Spatial distribution of Arabica coffee and biophysical characterization}

The estimated area of Arabica coffee production in Rwanda was about 32,000 ha in 2005, compared to 30,000 ha reported by FAO (2014). This area represents about $2.3 \%$ of the total area under agriculture. The Central Plateau had the largest area of coffee production, covering about $32 \%(10,261 \mathrm{ha})$ of the total area under coffee cultivation. The Central Plateau was characterized by coffee yields of 0.3-2.8 $\mathrm{t} \mathrm{ha}^{-1}$ (Table 3.2). This zone has a wide range of soil types and landscapes. The soils where coffee is cultivated included Alfisols, Inceptisols, and Ultisols, representing 4\% (1,306 ha), 10\% (3,286 ha) and 12\% (3,722 ha), respectively, of the total area under coffee (Table 3.3). Cultivated areas in the Central Plateau and the Granitic Ridge agro-ecological zones are also characterized by moderate $(<25 \%)$ and steep (25-55\%) slopes that cover $23 \%(7,212 \mathrm{ha})$ and $9 \%(2,944 \mathrm{ha})$ of the total cultivated area, respectively (Table 3.4 ). Coffee productivity is mainly limited by infertile soils derived from schistose and granitic materials. Slopes above $25 \%$ affect the productivity of the region due to soil erosion. 
The Lake Kivu region (Imbo, Impara, and Kivu Lake Borders zones) in the western province had the highest yields ranging between 0.3 and $3.5 \mathrm{t} \mathrm{ha}^{-1}$, with a mean of $1.6 \mathrm{t} \mathrm{ha}^{-1}$. This region contained $22 \%(7,127 \mathrm{ha})$ of the total area cropped with coffee (Table 3.2$)$. The dominant soil types in the region are Inceptisols and Ultisols, representing 6\% (2,025 ha) and $11 \%$ (3,384 ha), respectively, of the total area devoted to coffee production (Table 3.3). Arabica coffee in the region is dominantly cultivated on moderate $(<25 \%)$ and steep slopes $(25-55 \%)$ that cover $15 \%(4,882 \mathrm{ha})$ and $6 \%(2,125 \mathrm{ha})$, respectively, of the areas under coffee (Table 3.4). The region is characterized by environmental conditions favorable to coffee production.

Yields in the Birunga (volcano) agro-ecological zone ranged between 0.5 and $2.1 \mathrm{t} \mathrm{ha}^{-1}$, with a mean of $1.0 \mathrm{t} \mathrm{ha}^{-1}$ (Table 3.2). The extent of coffee in the zone covered only 65 ha of the land, mainly on Alfisols (16 ha), Andisols (23 ha), and Ultisols (15 ha) (Table 3.3). Andisols are fertile and productive soils, so the farmers will prefer annual crops over perennial crops such as coffee. Coffee is mainly grown on moderate slopes (Table 3.4). The effective depth of the soil, dominated by Andisols, is the main factor limiting coffee productivity in the zone.

The Eastern Plateau, Eastern Savanna, Mayaga, and Bugesera zones (i.e. the eastern region) together covered $\sim 30 \%(9,418 \mathrm{ha})$ of the total area of coffee production. Yields in the eastern region ranged between 0.3 and $2.2 \mathrm{t} \mathrm{ha}^{-1}$, with a mean of $1.0 \mathrm{t} \mathrm{ha}^{-1}$ (Table 3.2). The dominant soil types are Inceptisols, Oxisols, and Ultisols, covering 6\% (2,013 ha), 9\% (2,928 ha), and 5\% (1,647 ha), respectively, of the area under coffee (Table 3.3). Coffee is cultivated on moderate slopes $(<25 \%)$ that cover more than $26 \%(8,271 \mathrm{ha})$ of the area with coffee cultivation (Table 3.4). The dominant infertile soils of the region, very high temperatures, and low rainfall offer limited conditions for coffee productivity.

The Buberuka Highlands and the Congo-Nile Watershed Divide agro-ecological zones are classified as the highlands of the country (above 2,000 m a.s.l.). In both zones, coffee was cultivated on $\sim 16 \%(5,154 \mathrm{ha})$ of the total coffee area, mainly on moderate $(2,494$ ha, $8 \%)$ and steep (2,555 ha, $8 \%$ ) (Table 3.4). Yields in the highlands ranged between 0.3 and $3.5 \mathrm{t}$ $\mathrm{ha}^{-1}$, with a mean of $1.2 \mathrm{t} \mathrm{ha}^{-1}$ (Table 3.2). Inceptisols and Ultisols are the main soil types, representing $\sim 6 \%(1,938 \mathrm{ha})$ and $8 \%(2,460 \mathrm{ha})$, respectively, of the total area under coffee cultivation (Table 3.3 ). Very low temperatures and heavy rainfall limit the productivity of coffee cultivation in the highlands. 


\begin{tabular}{|c|c|c|c|c|c|c|c|}
\hline AEZ No. & Agro-Ecological Zone (D’haeze et al.) & $\begin{array}{c}\text { Total area } \\
\text { (ha) }\end{array}$ & $\begin{array}{c}\text { Area with } \\
\text { scattered coffee } \\
\text { trees }^{\mathrm{a}}(\mathrm{ha})\end{array}$ & $\begin{array}{c}\text { Normalized } \\
\text { areab (ha) }^{\text {b }}\end{array}$ & $\begin{array}{c}\text { Range of } \\
\text { estimated } \\
\text { dry yieldc } \\
\left(\mathrm{t} \mathrm{ha}^{-1}\right)\end{array}$ & $\begin{array}{c}\text { Mean dry } \\
\text { coffee yield } \pm \\
\text { SD }^{d} \\
\left(\mathrm{t} \mathrm{ha}^{-1}\right)\end{array}$ & $\begin{array}{l}\text { Number of } \\
\text { sectors } \\
\text { (n) }\end{array}$ \\
\hline 1 & Imbo (Lake Kivu region) & 15,832 & 15,678 & 804 & $0.5-2.6$ & $1.2 \pm 0.68$ & 9 \\
\hline 2 & Impara (Lake Kivu region) & 64,954 & 58,532 & 3,376 & $0.5-2.6$ & $1.2 \pm 0.69$ & 21 \\
\hline 3 & Kivu Lake Borders (Lake Kivu region) & 73,593 & 70,422 & 2,947 & $0.3-3.5$ & $1.6 \pm 0.79$ & 30 \\
\hline 4 & Birunga/Volcano & 90,887 & 1,952 & 65 & $0.5-2.1$ & $1.0 \pm 0.74$ & 4 \\
\hline 5 & Congo-Nile Watershed Divide & 391,930 & 136,946 & 4,024 & $0.3-3.5$ & $1.2 \pm 0.91$ & 45 \\
\hline 6 & Buberuka Highlands & 177,154 & 81,622 & 1,130 & $0.3-2.8$ & $0.8 \pm 0.53$ & 45 \\
\hline 7 & Central Plateau \& Granitic Ridge & 529,772 & 461,743 & 10,155 & $0.3-2.8$ & $0.8 \pm 0 . .47$ & 127 \\
\hline 8 & Mayaga-Bugesera (eastern region) & 223,573 & 166,085 & 3,328 & $0.5-1.8$ & $1.0 \pm 0.41$ & 42 \\
\hline 9 & Eastern Plateau (eastern region) & 381,367 & 350,233 & 5,398 & $0.3-2.2$ & $0.8 \pm 0.65$ & 86 \\
\hline \multirow[t]{2}{*}{10} & Eastern Savana (eastern region) & 479,761 & 134,125 & 692 & $0.5-2.2$ & $1.1 \pm 0.49$ & 20 \\
\hline & Total & $2,564,255$ & $1,162,338$ & 31,921 & & $1.0 \pm 0.65$ & 438 \\
\hline
\end{tabular}

a This area is calculated as the area for each sector in the AEZ; only the sector area in the AEZ is extracted by spatial-analysis tools. The 2005 Rwanda coffee database displays only the number of coffee trees and coffee production per sector. Each sector is an administrative entity divided into cells, which are the lowest administrative units within the Republic of Rwanda.

b This area is extracted from the area with scattered coffee trees in each AEZ and is calculated using the standard tree density of 2500 trees ha- 1 , i.e. $b=a / 2500$.

c This yield is calculated by averaging the yields for each part of the sector in the AEZ (i.e. sector yield is calculated as the production of each sector divided by the number of trees using the standard spacing of $2 \times 2 \mathrm{~m}$, or 2500 trees ha-1).

d This yield is calculated using SPSS descriptive statistics; the normality of the data was determined using the Kolmogorov-Smirnov test. 
Table 3.3A Distribution of soil types (ha) and areas of Arabica coffee cultivation in the ten agro-ecological zones of Rwanda. Data were extracted from the Rwanda soil dataset and analyzed using the geo-spatial tools of ArcGIS.

\begin{tabular}{|c|c|c|c|c|c|c|c|c|c|c|c|c|}
\hline \multirow{2}{*}{ AEZNo. } & \multirow{2}{*}{$\begin{array}{l}\text { Agro-Ecological Zone } \\
\text { (D'haeze et al.) }\end{array}$} & \multirow{2}{*}{$\begin{array}{l}\text { Soil/Coffee } \\
\text { coverage }\end{array}$} & \multicolumn{8}{|c|}{ Area per soil type/Area covered by coffee per soil type (ha) ${ }^{a}$} & \multicolumn{2}{|c|}{ Total } \\
\hline & & & ALF & AND & ENT & HIST & INCEPT & MOLL & OX & ULT & hab & $\%^{\mathrm{c}}$ \\
\hline \multirow[t]{2}{*}{1} & $\begin{array}{l}\text { Imbo (Lake Kivu } \\
\text { region) }\end{array}$ & Soil & 3,349 & - & 268 & - & 6,489 & - & - & 3,910 & 14,017 & 0.6 \\
\hline & & Coffee & 197 & - & 16 & - & 382 & - & - & 230 & 825 & 3 \\
\hline \multirow[t]{2}{*}{2} & $\begin{array}{l}\text { Impala (Lake Kivu } \\
\text { region) }\end{array}$ & Soil & 11,831 & - & 138 & 1,269 & 10,111 & - & 363 & 40,436 & 64,147 & 3 \\
\hline & & Coffee & 657 & - & 7 & 75 & 558 & - & 1 & 2,109 & 3,407 & 11 \\
\hline \multirow[t]{2}{*}{3} & $\begin{array}{l}\text { Kivu Lake Borders } \\
\text { (Lake Kivu region) }\end{array}$ & Soil & 8,526 & 91 & 12,708 & 35 & 25,248 & 258 & 253 & 25,469 & 72,590 & 3 \\
\hline & & Coffee & 328 & - & 539 & 2 & 1,085 & 11 & 11 & 1,045 & 3,020 & 9 \\
\hline \multirow[t]{2}{*}{4} & Birunga/Volcano & Soil & 1,782 & 47,176 & 15,450 & 79 & 2,182 & 4,222 & - & 3,174 & 74,065 & 3 \\
\hline & & Coffee & 16 & 23 & - & - & 5 & 7 & - & 15 & 65 & 0.2 \\
\hline \multirow[t]{2}{*}{5} & $\begin{array}{c}\text { Congo-Nile Watershed } \\
\text { Divide }\end{array}$ & Soil & 8,879 & 11,613 & 23,396 & 5,388 & 124,675 & 2,107 & 11,341 & 203,960 & 391,359 & 17 \\
\hline & & Coffee & 112 & - & 330 & 8 & 1,553 & - & 17 & 2,004 & 4,024 & 13 \\
\hline \multirow[t]{2}{*}{6} & Buberuka Highlands & Soil & 2,000 & 99 & 17,838 & 10,545 & 45,835 & 567 & 10,492 & 81,901 & 167,277 & 7 \\
\hline & & Coffee & 21 & - & 157 & 19 & 385 & 7 & 73 & 456 & 1,118 & 3 \\
\hline
\end{tabular}

a AND, Andisols; ALF, Alfisols; ENT, Entisols; INCEPT, Inceptisols; HIST, Histosols; MOLL, Mollisols; OX, Oxisols; ULT, Ultisols; VERT, Vertisols.

${ }^{b}$ Total Rwanda soil and Arabica coffee coverage per agro-ecological zone.

c Soil and Arabica coffee coverage in percentage per agro-ecological zone over total Rwanda soil area and Arabica coffee area, respectively.

${ }^{\mathrm{d}}$ Subtotal of soil area per soil type.

e Subtotal of Arabica coffee area per soil type. 
Table 3.3B Distribution of soil types (ha) and areas of Arabica coffee cultivation in the ten agro-ecological zones of Rwanda. Data were extracted from the Rwanda soil dataset and analyzed using the geo-spatial tools of ArcGIS (cont'd).

\begin{tabular}{|c|c|c|c|c|c|c|c|c|c|c|c|c|}
\hline \multirow{2}{*}{$\begin{array}{l}\text { AEZ } \\
\text { No. }\end{array}$} & \multirow{2}{*}{$\begin{array}{l}\text { Agro-Ecological Zone } \\
\text { (D'haeze et al.) }\end{array}$} & \multirow{2}{*}{$\begin{array}{l}\text { Soil/Coffee } \\
\text { coverage }\end{array}$} & \multicolumn{8}{|c|}{ Area per soil type/Area covered by coffee per soil type (ha) ${ }^{a}$} & \multicolumn{2}{|c|}{ Total } \\
\hline & & & ALF & AND & ENT & HIST & INCEPT & MOLL & $\mathrm{OX}$ & ULT & hab & $\%^{\mathrm{c}}$ \\
\hline \multirow[t]{2}{*}{7} & $\begin{array}{l}\text { Central Plateau \& } \\
\text { Granitic Ridge }\end{array}$ & Soil & 68,244 & 373 & 47,504 & 2,219 & 164,855 & 1,634 & 48,054 & 195,007 & 527,890 & 23 \\
\hline & & Coffee & 1,306 & 5 & 876 & 30 & 3,286 & 34 & 778 & 3,722 & 10,036 & 31 \\
\hline \multirow[t]{2}{*}{8} & $\begin{array}{c}\text { Mayaga-Bugesera } \\
\text { (eastern region) }\end{array}$ & Soil & 14,564 & - & 13,650 & 28,515 & 34,038 & 5,768 & 75,141 & 37,048 & 208,722 & 9 \\
\hline & & Coffee & 288 & - & 206 & 392 & 599 & 86 & 1,182 & 569 & 3,322 & 10 \\
\hline \multirow[t]{2}{*}{9} & $\begin{array}{l}\text { Eastern Plateau } \\
\text { (eastern region) }\end{array}$ & Soil & 22,782 & - & 66,166 & 10,652 & 76,506 & 20,420 & 99,118 & 76,238 & 371,881 & 16 \\
\hline & & Coffee & 311 & - & 910 & 161 & 1,111 & 294 & 1,459 & 1,021 & 5,268 & 16 \\
\hline \multirow[t]{6}{*}{10} & $\begin{array}{l}\text { Eastern Savana } \\
\text { (eastern region) }\end{array}$ & Soil & 10,555 & - & 48,331 & 38,421 & 89,951 & 20,235 & 186,596 & 26,586 & 420,676 & 18 \\
\hline & & Coffee & 21 & - & 118 & 58 & 303 & 26 & 287 & 57 & 870 & 3 \\
\hline & & $\begin{array}{l}\text { Subtotald }^{d} \\
\text { (ha) }\end{array}$ & 152,513 & 59,352 & 245,450 & 97,123 & 579,890 & 55,211 & 431,358 & 693,728 & $2,314,625$ & \\
\hline & & $\begin{array}{l}\text { Subtotald } \\
(\%)\end{array}$ & 7 & 3 & 11 & 4 & 25 & 2 & 19 & 30 & & 100 \\
\hline & & $\begin{array}{l}\text { Subtotale } \\
\text { (ha) }\end{array}$ & 3,257 & 27 & 3,159 & 743 & 9,266 & 465 & 3,809 & 11,228 & 31,954 & \\
\hline & & $\begin{array}{l}\text { Subtotale } \\
\text { (\%) }\end{array}$ & 10 & 0.1 & 10 & 2 & 29 & 1 & 12 & 35 & & 100 \\
\hline
\end{tabular}


Table 3.4 Distribution of slope classes (\%) and areas with Arabica coffee in the ten agro-ecological zones of Rwanda. Data extracted from the digital elevation model (Shuttle Radar Topography Mission at $90 \times 90 \mathrm{~m}$ resolution) and analyzed using the geo-spatial tools of ArcGIS.

\begin{tabular}{|c|c|c|c|c|c|c|c|}
\hline \multirow{2}{*}{$\begin{array}{l}\text { AEZ } \\
\text { No. }\end{array}$} & \multirow[t]{2}{*}{ Agro-Ecological Zone (D’haeze et al.) } & \multirow{2}{*}{$\begin{array}{l}\text { Slope/Coffee } \\
\text { coverage }\end{array}$} & \multicolumn{3}{|c|}{$\begin{array}{l}\text { Area per slope category/Area covered by coffee per slope } \\
\text { category (ha) }\end{array}$} & \multicolumn{2}{|c|}{ Total } \\
\hline & & & $<25 \%$ & $25-55 \%$ & $>55 \%$ & (ha) & $(\%)^{\mathrm{a}}$ \\
\hline \multirow[t]{2}{*}{1} & Imbo (Lake Kivu region) & Slope & 10,863 & 4,652 & 4,705 & 20,220 & 1 \\
\hline & & Coffee & 554 & 238 & 11 & 803 & 3 \\
\hline \multirow[t]{2}{*}{2} & Impara (Lake Kivu region) & Slope & 45,321 & 18,165 & 1,407 & 64,893 & 3 \\
\hline & & Coffee & 2,417 & 871 & 57 & 3,345 & 10 \\
\hline \multirow[t]{2}{*}{3} & Kivu Lake Borders (Lake Kivu region) & Slope & 47,780 & 25,400 & 413 & 73,593 & 3 \\
\hline & & Coffee & 1,911 & 1,016 & 17 & 2,944 & 9 \\
\hline \multirow[t]{2}{*}{4} & Birunga/Volcano & Slope & 77,170 & 12,396 & 1,226 & 90,792 & 4 \\
\hline & & Coffee & 59 & 6 & - & 65 & 0.2 \\
\hline \multirow[t]{2}{*}{5} & Congo-Nile Watershed Divide & Slope & 229,902 & 157,739 & 4,258 & 391,899 & 16 \\
\hline & & Coffee & 2,059 & 1,922 & 46 & 4,027 & 13 \\
\hline \multirow[t]{2}{*}{6} & Buberuka Highlands & Slope & 81,303 & 89,874 & 5,814 & 176,991 & 7 \\
\hline & & Coffee & 435 & 633 & 50 & 1,118 & 3 \\
\hline \multirow[t]{2}{*}{7} & Central Plateau \& Granitic Ridge & Slope & 369,316 & 155,345 & 5,070 & 529,731 & 22 \\
\hline & & Coffee & 7,212 & 2,944 & 105 & 10,261 & 32 \\
\hline \multirow[t]{2}{*}{8} & Mayaga-Bugesera (eastern region) & Slope & 214,946 & 8,122 & 19 & 223,087 & 9 \\
\hline & & Coffee & 3,168 & 152 & - & 3,320 & 10 \\
\hline \multirow[t]{2}{*}{9} & Eastern Plateau (eastern region) & Slope & 316,686 & 63,065 & 1,586 & 381,337 & 16 \\
\hline & & Coffee & 4,462 & 903 & 24 & 5,389 & 17 \\
\hline \multirow[t]{6}{*}{10} & Eastern Savana (eastern region) & Slope & 453,244 & 25,987 & 202 & 479,433 & 20 \\
\hline & & Coffee & 641 & 57 & - & 698 & 2 \\
\hline & Rwanda - Slope (ha) & Subtotal & $1,846,532$ & 560,746 & 24,701 & $2,431,979$ & \\
\hline & (\%) & & 76 & 23 & 1 & & 100 \\
\hline & Rwanda - Coffee (ha) & Subtotal & 22,917 & 8,743 & 310 & 31,970 & \\
\hline & (\%) & & 72 & 27 & 1 & & 100 \\
\hline
\end{tabular}

a Slope and coffee coverage in percentages per agro-ecological zone of the total Rwanda slope and coffee areas, respectively. 


\subsubsection{Coffee productivity indices}

Qualitative productivity indices were generated based on soil type, elevation, slope, rainfall, and temperature using weighted overlay analysis (Fig. 3.2). The analysis identified three zones with high, moderate, and low productivity indices representing 930,715 ha (39\%), 949,975 ha $(40 \%)$, and 511,945 ha $(21 \%)$, respectively. Approximately $80 \%$ of the total area of the country had moderate to high production potential for Arabica coffee. Zones with high potential productivity indices had fertile soils, moderate slopes and altitudes, and favorable climates. The zones with low productivity indices were mainly at high altitudes with high rainfall and low temperatures. The semi-dry eastern regions, where Oxisols and Ultisols are the dominant soil types, has zones with low indices (Fig. 3.5).

High predicted yields ranged between 1.6 and $2.4 \mathrm{t} \mathrm{ha}^{-1}$ along the shores of Lake Kivu and in the Imbo zone (Fig. 3.3). The calculated yields varied between 0.3 and $3.5 \mathrm{t} \mathrm{ha}^{-1}$ (Table 3.2). The prediction map for the country (Fig. 3.3) shows coffee yields varying between 0.3 and $2.4 \mathrm{t} \mathrm{ha}^{-1}$. Eighty percent of the country had low yield potentials of 0.3 to $1 \mathrm{t} \mathrm{ha} \mathrm{h}^{-1}$, whereas $21 \%$ of the country had moderate yield potentials of 1.0 to $1.6 \mathrm{t} \mathrm{ha}^{-1}$. The national average yield was predicted to be $1.12 \mathrm{t} \mathrm{ha}^{-1}$, and the measured yield ( $\mathrm{n}=121$ sampled sites) was $1.1 \mathrm{t} \mathrm{ha}^{-1} \mathrm{y}^{-1}$. The correlation between the measured and predicted yields indicated that the prediction model was satisfactory (Coefficient of determination $\mathrm{R}^{2}=0.73$ ) (Fig. 3.4). 


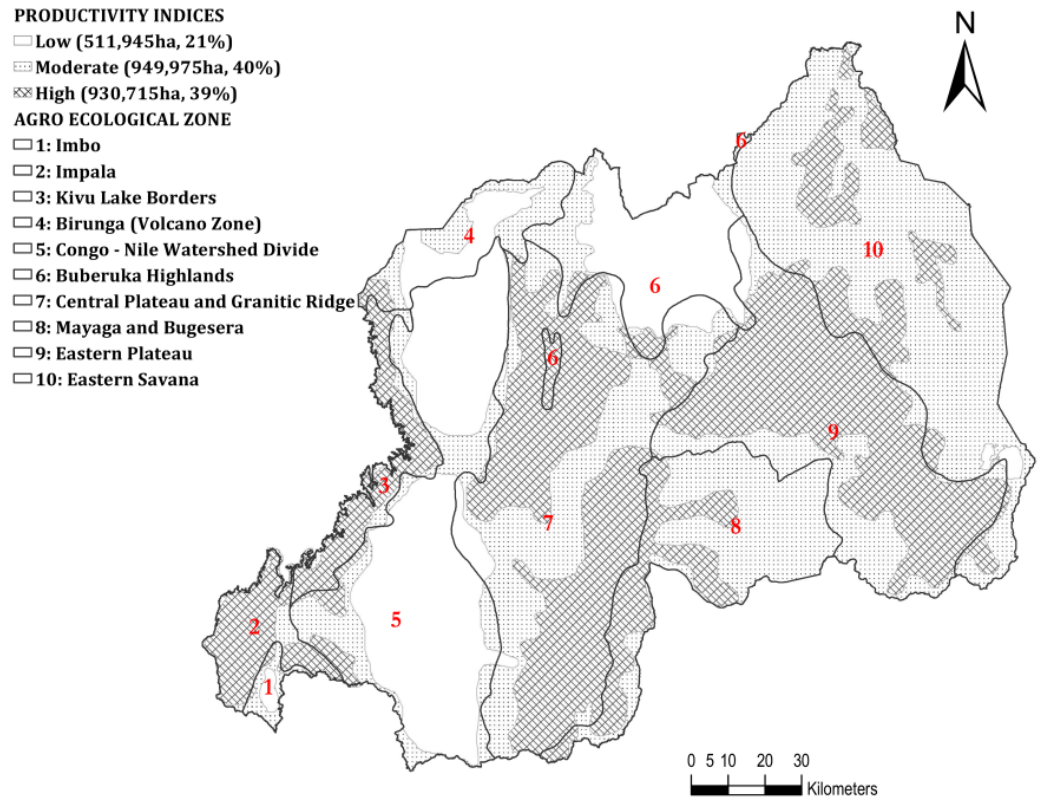

Figure 3.2 Qualitative Arabica coffee productivity indices (low, moderate, and high) generated by combining factors (elevation, slope, soil type, rainfall, and temperature) using weighted overlay analysis in the ten agro-ecological zones.

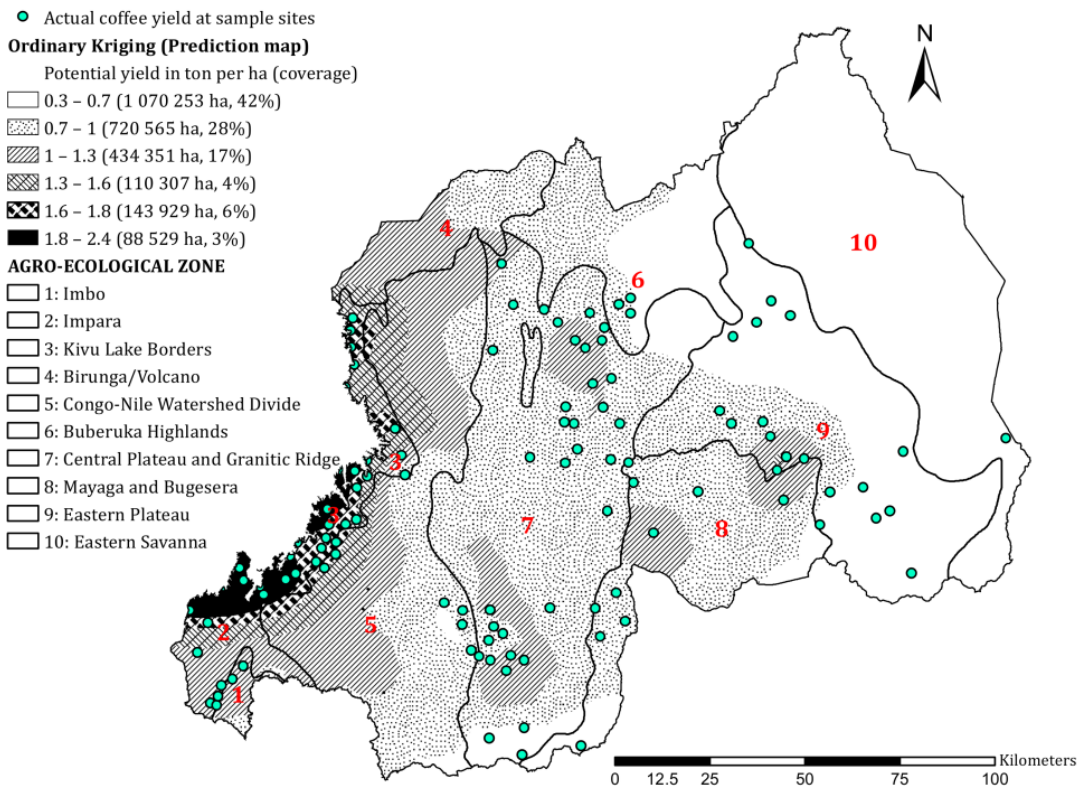

Figure 3.3 Potential Arabica coffee yield $\left(t h a^{-1}\right)$ predicted using ordinary kriging in the ten agroecological zones based on actual yields $\left(t \mathrm{ha}^{-1}\right)$ measured at sample sites. 


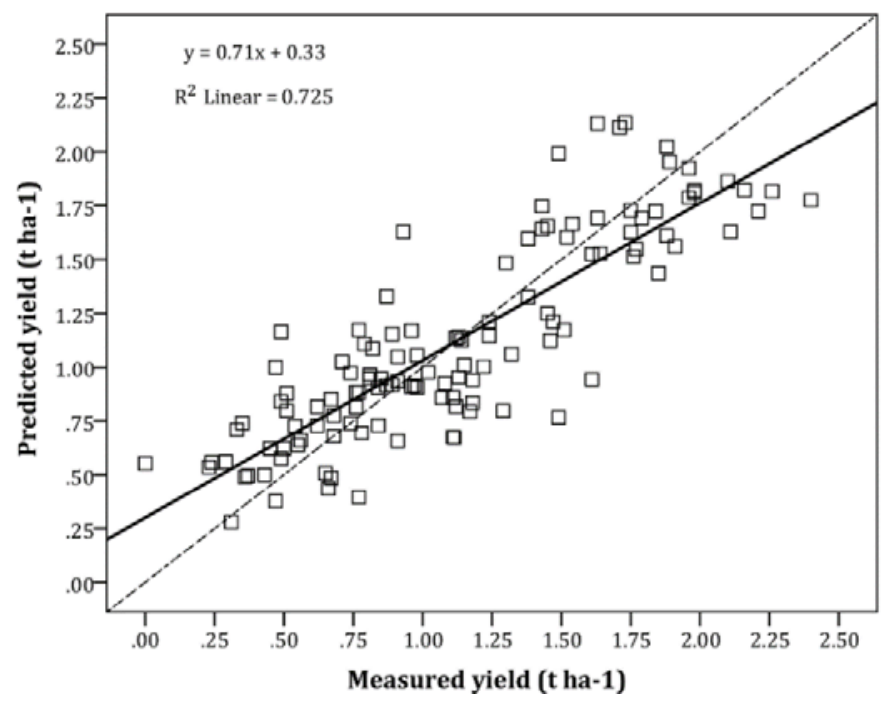

Figure 3.4 Relationship between measured and predicted Arabica coffee yields - cross validation using ordinary kriging (Predicted Arabica coffee yield index $-\mathrm{CYI}(\mathrm{t}$ ha-1) $=0.71 \mathrm{x}+0.33$; Mean Prediction Error - MPE = 0.0187; Root Mean Square Prediction Error $-R M S E=0.278 ;$ Root Mean Square Standardized Prediction Error - RMSSE $=0.99$; Mean Standardized Prediction Error - MSE $=0.036$; Coefficient of determination $-R 2=0.73$; Average Standard Error - Avg. $S E=0.291$; Sample points, $n=121$ ).

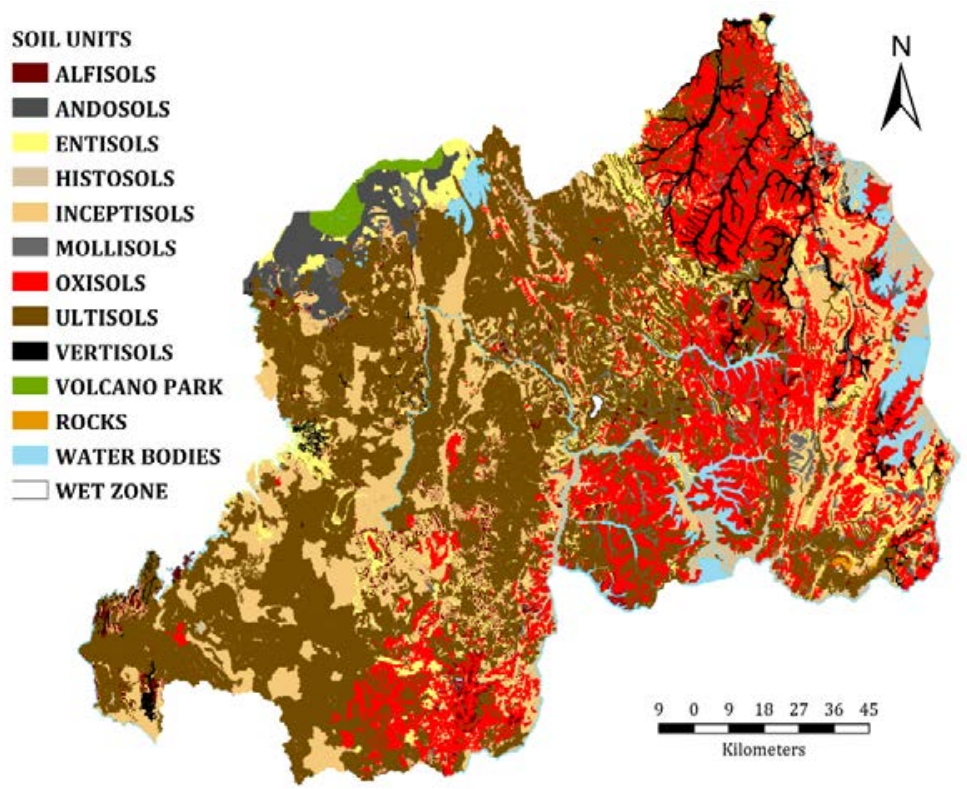

Figure 3.5 Soil map of Rwanda. Soils are classified using the USDA Soil taxonomy (Source: Data collected from the Ministry of Agriculture and Animal Resources, using the Rwanda soil database) after (Birasa et al., 1990). 


\subsection{Discussion}

Some general information on the suitability of coffee cultivation in Rwanda was available. The spatial variation of coffee production can be explained by the growing conditions, which include biophysical factors such as soil type and properties, parent material, altitude, slope, and climatic conditions. For example, the yield in the Central Plateau and Granitic Ridge zones was limited by soil acidity and the gravel as these soils developed on granitic and schistose materials. On such soils, erosion on slopes above $25 \%$ affects the productivity. Similar observations have been made by Changere and LaL (1997) and Moore et al. (1993) who indicated that topography can combine with various environmental factors to influence productivity. Topography affects the climate (e.g. variations in temperature and humidity), distribution of soil moisture, soil organic-matter content, soil nutrients, soil textural composition, and soil physical properties, which affect crop growth and yield in a field. The spatial variability of environmental factors can contribute to variability in crop performance, and topography is a vital variable in predicting the spatial variability of crop yields (Kravchenko and Bullock, 2000).

The multi-criteria overlay analysis used to assess spatial variation in coffee productivity revealed that the Lake Kivu region is an area of high productivity. Similarly, ordinary kriging indicated expected high yields. The Lake Kivu region has favorable soil types and slopes with abundant rainfall and moderate temperatures for the optimal production of coffee. The region has alluvial and very fine clayey soils, developed from basalt, and a high agricultural potential (Verdoodt and Van Ranst, 2003).

The Birunga (volcano), Central Plateau, and Buberuka Highlands' zones, the highlands of the Congo-Nile Watershed Divide zone, and the eastern region are areas with both moderate and low productivity indices. The productivity in the Central Plateau zone is mainly limited by infertile soils derived from schistose and granitic materials on the moderately sloped and eroded hillsides. The productivity in the Birunga (volcano) zone is mainly limited by the soil depth $(<50 \mathrm{~cm})$ and low temperatures that are sub-optimal for coffee production. High yields were expected in this zone based on the high fertile volcanic soils. Instead, low potential yields were predicted by the kriging model, due to the unsuitable climatic conditions that affect the development and maturity of the berries (Descroix and Snoeck, 2004). In the highlands, mainly in the Buberuka Highlands and Congo-Nile Watershed Divide zones, the production of coffee is limited by very low temperatures, heavy rainfall, and steep slopes that could influence the depletion of soil fertility and reduce yields due to water erosion on the hills. Productivity in the eastern regions is limited by infertile soils and the very high temperatures and low rainfall. Our study demonstrated a decrease in yield in very dry conditions that coincided with lower elevations. Coffee is also constrained by very 
cold temperatures in the highlands that are often cloudy with low solar irradiation and heavy rainfall. Similar trends of the influence of topography on potato yields have also been reported by Soltani et al. (2013). Both the ordinary kriging analysis and the multi-criteria factor analysis thus performed well in assessing and predicting potential yields of coffee. The performance of weighted overlay analysis has also been assessed in cotton by Walke et al. (2012). The relationships of soil, elevation, slope, aspect, and curvature with the stability of crop yields were assessed by McKinion et al. (2010), who deemed ordinary kriging the best method to estimate crop yield as a function of topography and landscape positions.

A wide range of yields of coffee in Rwanda, varying between 0.8 and $2.8 \mathrm{t} \mathrm{ha}^{-1}$ of dry parchment coffee, has also been reported by Nzeyimana et al. (2013). The low yields were attributed to coffee variety, agro-ecological conditions, the lack of mineral and organic fertilization, and limited mulching (Nzeyimana et al., 2013). The national average yield of coffee is estimated at $1.1 \mathrm{t} \mathrm{ha}^{-1} \mathrm{y}^{-1}$ (this study), but yields above $2.8 \mathrm{t} \mathrm{ha}^{-1}$ for dry coffee are rare even with adequate fertilization and sustained crop management (Nzeyimana et al., 2013). In Uganda, $1.2 \mathrm{t} \mathrm{ha}^{-1} \mathrm{y}^{-1}$ of dry coffee were recorded for mono-cropped coffee and coffee-banana intercropping systems (Van Asten et al., 2011). The spatial variation in coffee production and productivity are thus mainly influenced by soil properties, soil management, farming practices, and climatic conditions. Similar trends have also been reported by Changere and LaL (1997) and Kravchenko and Bullock (2000).

\subsection{Conclusions}

The multi-criteria analysis used to assess spatial variation in potential production zones and the productivity of coffee revealed that agro-ecological factors are largely determined suitable zones of coffee productivity. The spatial variation of coffee productivity in the agroecological zones was considerable and was influenced by soil properties, soil management, farming practices, and climatic conditions. High production potentials indicated that smallholder farmers could generate income from coffee and could thus improve their livelihoods. In addition, this may provide an opportunity for farmers to purchase more land and extend the area for the production of coffee.

This study demonstrated that both ordinary kriging analysis and multi-criteria weighted overlay analysis performed well for analyzing the spatial distribution and productivity of coffee and for predicting yield. The depletion of soil fertility due to the lack of erosion control in scattered coffee plots on steep slopes is a major factor limiting coffee productivity in Rwanda. The sustainability of coffee productivity could be ensured by intensifying the use of fertilizers, mainly a well-balanced combination of lime, nitrogen, phosphorus, potassium, 
zinc, and boron. Limited access to financial resources restricts the purchase of these inputs and the use of different types of mulches that can improve soil properties and reduce the erodibility of the soil is recommended.

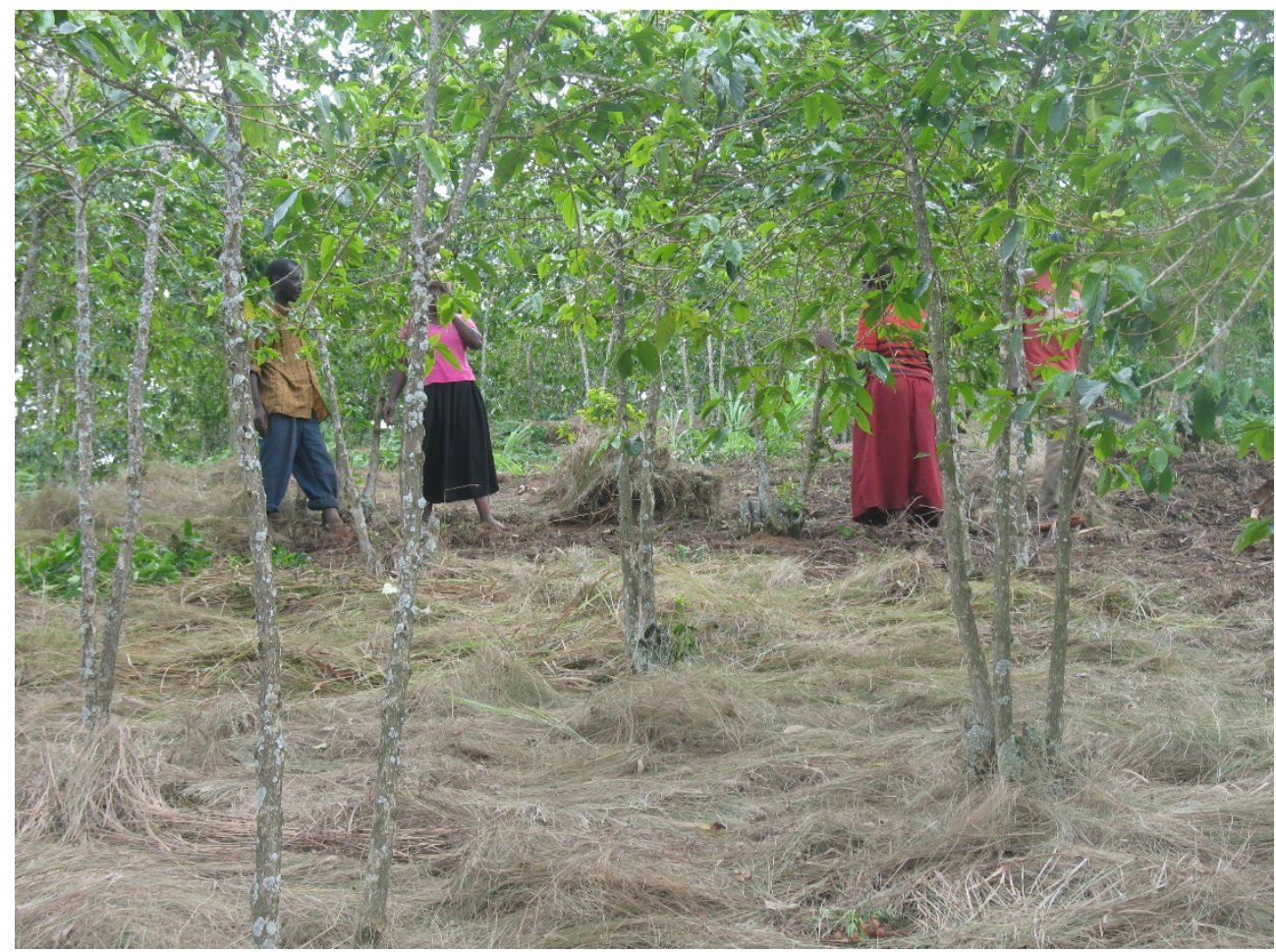




\section{Mulching as a strategy to improve soil properties and reduce soil erodibility in coffee farming systems of Rwanda}

In Rwanda, mulch is applied in coffee fields to control soil erosion. The objective of this paper is to quantify the effects of different types of mulch on soil properties and soil erodibility in coffee farming systems in three different agro-ecological zones of the highlands of Rwanda. The treatments consisted of five mulching systems (T1: Cympobogon spp.; T2: Panicum spp.; T3: Cympobogon spp. and Panicum spp.; T4: Eucalyptus spp. and Cympobogon spp.; T5: mixed residues) and control (un-mulched coffee - T6). The mulching systems were selected in coffee plantations to which the same mulch material had been applied annually

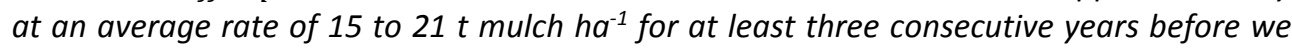
started field experiments in 2007. We tested the effects from 2007 to 2008 on two soil types. A factorial two-way ANOVA was used to assess the effects of the application of different mulch types on the soil organic carbon, bulk density, wet aggregate stability, and soil erodibility at each site. The application of mulch significantly reduced the bulk density and soil erodibility $(P<0.001)$ and significantly increased the soil organic carbon and wet aggregate stability $(P<0.001)$, mainly at Kibirizi and Karongi. In addition, the effects of the interactions between the type of mulch and type of soil were site specific $(P<0.001)$. Low bulk densities and soil erodibility as well as high soil organic carbon and wet aggregate stability values were observed mainly in response to the application of a mixture of mulches, particularly T4 and T5 at rates of above $17 t h^{-1}$. The maximum erodibility values coincided with the lowest values of soil organic carbon and wet aggregate stability and the highest bulk density. In addition, soil erodibility was also affected by soil texture; high sand and very fine sand fractions increased the vulnerability of soils to erosion. Mulching demonstrated positive effects on soil properties and soil erodibility, but the effects were site specific, depending on the agro-ecological conditions of the study sites and the types of mulch used.

Based on: Innocent Nzeyimana, Alfred E. Hartemink, Coen J. Ritsema, Leo Stroosnijder, Esperanza Huerta Lwanga, Violette Geissen. 2017. Mulching as a strategy to improve soil properties and reduce soil erodibility in coffee farming systems of Rwanda. Catena 149: 43-51. 


\subsection{Introduction}

The reduction of soil erodibility in arable lands is important to maintain long-term agricultural productivity and sustainability (Lal et al., 2000; Svoray and Ben-said, 2009). Mulching is known to play an important role in erosion control (Adekalu et al., 2006; Blavet et al., 2009; Poesen and Lavee, 1991 ; Smets et al., 2008). The application of crop residue mulches can contribute to improve the soil fertility and soil properties that affect crop productivity (Jordán et al., 2010; Mulumba and Lal, 2008). The mulching of agricultural lands increases the content of soil organic matter (Duiker and Lal, 1999; Saroa and Lal, 2003) that helps to improve soil aggregation (Mulumba and Lal, 2008), and hence positively affects soil porosity, which improves water infiltration, reduces runoff and controls soil erosion (Edwards et al., 2000 ; Jordán et al., 2010; McGregor et al., 1990; Mulumba and Lal, 2008; Rees et al., 2002; Roose and Ndayizigiye, 1997). When straw mulching was used on erosion plots over a 3-year experiment, soil losses decreased by $49 \%$ (Edwards et al., 2000 ). The effectiveness of mulch depends on the amount of mulch applied (Mulumba and Lal, 2008), slope gradient, soil type, land use, soil management practices, and rainfall erosivity (Poesen and Lavee, 1991 ; Smets et al., 2008).

In the mountainous landscape of Rwanda, where most coffee is grown, mulching is adopted as a strategy to control soil erosion and possibly reverse soil fertility depletion. Most coffee plots are located between the $25-35 \%$ slope category. In the highlands, coffee is often cultivated on steep slopes above 55\% (Nzeyimana et al., 2014), where it faces serious problems, including soil erosion and the loss of soil fertility. As a perennial crop, coffee should protect the soil against erosion better than an annual crop because of its year-round soil cover (Hartemink, 2006). This characteristic is expressed by its low C-value in the Revised Universal Soil Loss Equation (Renard et al., 1997). With limited mineral and organic inputs, the density of coffee trees in Rwanda is low with less than 2,500 trees ha-1, which limits the soil cover, and part of the field is vulnerable to soil erosion. Furthermore, the distance from home to the coffee plots that are scattered on the hilly steep slopes reduces soil management practices, such as mulching, and influences the soil erodibility (Nzeyimana et al., 2013). Some coffee fields are intercropped with beans, soybeans or taro because of land scarcity and land pressure, which may increase the soil loss and decrease the soil fertility. Physical structures, such as radical terraces, slow-forming terraces and anti-erosion ditches, are mostly used in Rwanda to control soil erosion on annual crop fields (Bizoza and de Graaf, 2012). In Rwandan coffee farming, mulching is practiced to protect the surface soil from soil particle detachment and the continuous loss of soil nutrients. With $20 \mathrm{Mg} \mathrm{ha}$ ${ }^{1} \mathrm{y}^{-1}$ of mulch in coffee plantations in Rwanda, erosion is reduced by up to 0.1 to $1 \mathrm{Mg} \mathrm{ha}{ }^{-1}$ $\mathrm{y}^{-1}$ (Roose and Ndayizigiye, 1997). Studies in Colombia, Venezuela and Indonesia on runoff 
plots measured soil losses ranging from 0.2 to $8.9 \mathrm{Mg} \mathrm{ha}^{-1} \mathrm{y}^{-1}$ in established coffee plantations (lijima et al., 2003).

The data on the effectiveness of different types of mulch in controlling erosion and increasing soil nutrients are scarce in the different agro-ecological zones of Rwanda highland conditions. The objective of the present study is to quantify the effects of different mulching systems on soil properties and soil erodibility in coffee farming systems in three different agro-ecological zones of the highlands of Rwanda.

\subsection{Materials and Methods}

\subsubsection{Site description}

The study sites were located in the Kibirizi sector of the Nyamagabe District in the Southern Province, the Ruli sector of the Gakenke District in the Northern Province, and the GishyitaMubuga sectors of the Karongi District in the Western Province (Fig 4.1). The three sites are located in different agro-ecological zones. Kibirizi is located at the Congo-Nile Watershed Divide agro-ecological zone with altitudes varying between 1900 and $2500 \mathrm{~m}$ a.s.l.; the annual minimum and maximum temperatures average between 14 and $24^{\circ} \mathrm{C}$, and the annual rainfall averages between 1300 and $2000 \mathrm{~mm}$ with 273 days of rainfall. The soils are dominated by clay, loam and sandy loam soils derived from schistose materials; they are acidic, and their nutrient availability is poor. They are mostly classified as Ultisols, Inceptisols and Entisols according to Soil Taxonomy (Birasa et al., 1990). The Ruli site is located at the Central Plateau and granitic ridges, and its elevation varies between 1900 and $2300 \mathrm{~m}$ a.s.l.; the annual temperatures vary between 16 and $29^{\circ} \mathrm{C}$, and the annual rainfall varies between 1100 and $1500 \mathrm{~mm}$ with 243 days of rainfall. The soils are dominated by sandy clay loam and clay loam soils developed from granitic material and are mainly classified as Inceptisols, Ultisols and Alfisols. The Karongi site is located at the Lake Kivu border, and the soils are dominated by sandy clay loam, clay loam and sandy loam soils derived from shales and granites. The soils are mainly classified as Inceptisols and Ultisols according to the Soil Taxonomy. Except for the abrupt slopes that are strongly eroded, the level of soil fertility is moderate. The altitude varies between 1500 and $1900 \mathrm{~m}$; the annual rainfall and temperature vary from 1200 to $1300 \mathrm{~mm}$ (with 212 days of rainfall) and from 19 to $22.5^{\circ} \mathrm{C}$, respectively (Gasana, 1991; Verdoodt and Van Ranst, 2003). 


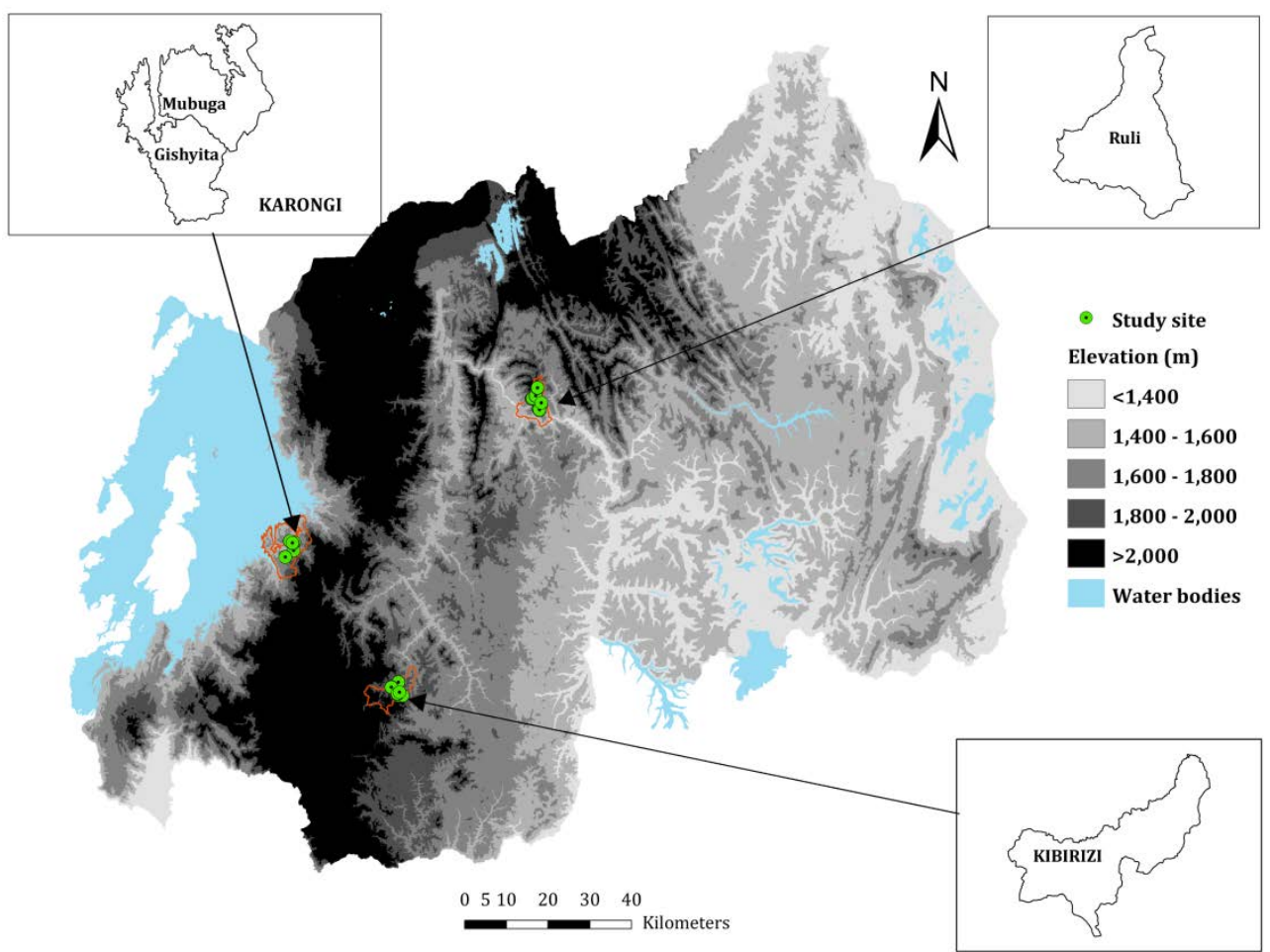

Figure 4.1. The elevation map of Rwanda with the locations of the three study sites (Kibirizi, Ruli, and Karongi)

\subsubsection{Experimental Design}

Field experiments were carried out from 2007 to 2008. The experimental design consisted of six treatments (i.e. five mulching systems + control) tested on two soil types (i.e., Inceptisols and Ultisols) at the three study sites, namely Kibirizi, Ruli and Karongi. The treatments were replicated three times at each site. The five mulching systems were selected from the most dominant mulching material used in coffee plantations by smallholder farmers in the study sites. The coffee plots selected for test were identified from plantations that received the same mulching material applied annually at an average rate of 15 - $21 \mathrm{t}$ mulch ha-1 at least for three consecutive years before the field experiments started in 2007. In addition, the selection of the coffee plantations took into account a mulch cover exceeding $75 \%$ and a slope gradient between 25 and $35 \%$. The amount and thickness of the applied mulch were measured using $1 \mathrm{~m}^{2}$ metal frame, and the percentage of the soil cover was estimated (Table 4.1). Each treatment was tested at a specific rate, i.e., $15,15,17,20,21$, and 0 t mulch ha ${ }^{-1}$ for $\mathrm{T} 1, \mathrm{~T} 2, \mathrm{~T} 3, \mathrm{~T} 4, \mathrm{~T} 5$, and T6, respectively. All of the 
selected experimental plots received annually $200 \mathrm{~kg} \mathrm{ha}^{-1}$ of NPK (10-20-20) applied in the areas surrounding the coffee stem two years prior to soil sampling. The size of each experimental plot was delimited to $10 \times 10 \mathrm{~m}$, and each plot contained 25 coffee trees (i.e., 2500 trees per ha) spaced $2 \mathrm{~m}$ apart.

Table 4.1 Description of the treatments

\begin{tabular}{|c|c|c|c|c|c|}
\hline Treatment & Mulching system* & $\begin{array}{l}\text { Period or number } \\
\text { of years of mulch } \\
\text { application }\end{array}$ & $\begin{array}{l}\text { Amount of } \\
\text { mulch } \\
\text { application } \\
\text { (t mulch ha-1) }\end{array}$ & $\begin{array}{l}\text { Mulch } \\
\text { thickness } \\
(\mathrm{mm})\end{array}$ & $\begin{array}{l}\text { Soil } \\
\text { cover } \\
(\%)\end{array}$ \\
\hline T1 & Cympobogon spp. & $>3$ & 15 & 22 & $75-80$ \\
\hline $\mathrm{T} 2$ & Panicum spp. & $>3$ & 15 & 20 & $75-80$ \\
\hline T3 & $\begin{array}{l}\text { Cympobogon spp. mixed with } \\
\text { Panicum spp. }\end{array}$ & $>3$ & 17 & 31 & $75-80$ \\
\hline T4 & $\begin{array}{l}\text { Eucalyptus spp. mixed with } \\
\text { Cympobogon spp. }\end{array}$ & $>3$ & 20 & 40 & $75-80$ \\
\hline T5 & $\begin{array}{l}\text { Mixed residues (i.e., sorghum } \\
\text { thatch, maize and beans residues, } \\
\text { banana leaves, Eucalyptus leaves } \\
\text { and branches, Panicum spp., sugar } \\
\text { cane) }\end{array}$ & $>3$ & 21 & 41 & $75-80$ \\
\hline T6 & Un-mulched control & $>3$ & 0 & 0 & 0 \\
\hline
\end{tabular}

N.B. ${ }^{*}$ Mulching systems selected from the most dominant mulching material used in coffee plantations by smallholder farmers in the study sites. The mulching systems were selected in coffee plantations to which the same mulch material had been applied annually at an average rate of $15-21$ t mulch ha-1 for at least three consecutive years before we started field experiments in 2007, and during the field experimentation period, i.e. from 2007 to 2009. The amount and thickness of the applied mulch were measured using $1 \mathrm{~m}^{2}$ metal frame, and the percentage of the soil cover was estimated.

\subsubsection{Soil sampling and analysis}

\subsubsection{Soil properties}

Composite topsoil samples $(0-10 \mathrm{~cm})$ were collected from each plot between coffee rows at the intersections of the cross-diagonals of 4 trees using an Edelman auger. The composite samples were made from 10 spots mixed in a bucket and used to analyse the particle size distribution (PSD), soil organic carbon (SOC), and wet aggregate stability (WAS). The PSD was analysed using the hydrometer method; the sand content was determined by wet sieving, while the silt and clay contents were determined using the hydrometer method (Okalebo et al., 2002). The SOC was analysed via the Walkey and Black method using a mixture of sulphuric acid and aqueous potassium dichromate ( $\mathrm{K} 2 \mathrm{Cr} 2 \mathrm{O} 7)$. A correction factor of 1.724 was used to convert the SOC into soil organic matter (SOM) (Okalebo et al., 2002). 
The wet aggregate stability was determined using a wet sieving apparatus as described by Eijkelkamp (2010):

$W A S=\frac{P S}{P S+P h}$

where WAS is the aggregate stability index, $\mathrm{Ps}_{\mathrm{s}}$ is the weight of stable aggregates $(\mathrm{NaOH}$ solution), and $\mathrm{Ph}_{h}$ is the weight of unstable aggregates $\left(\mathrm{H}_{2} \mathrm{O}\right)$.

The soil bulk density (BD) was determined using volumetric rings of $100 \mathrm{~cm}^{3}$, and samples were taken at a soil depth between 0 and $10 \mathrm{~cm}$ (Okalebo et al., 2002). The samples were collected in triplicate between coffee rows at the intersections of the cross-diagonals of 4 trees.

\subsubsection{Interrill and rill erosion}

The soil loss by interrill detachment $\left(D_{i}\right)$, expressed as $\mathrm{kg} \mathrm{m}^{-2} \mathrm{~s}^{-1}$, was determined using a portable rainfall simulator designed for erodibility studies (Romero et al., 2007). The field measurements were conducted from 2007 to 2008 to test erosion rates of the different treatments. The portable rainfall simulator measures the runoff, soil loss and infiltration generated by a standardised rainfall intensity of approximately $360 \mathrm{~mm} \mathrm{~h}^{-1}$ on a plot with a standard slope and surface area of $0.0625 \mathrm{~m}^{2}$. Before the rainfall simulation, the plot was prepared by removing stones and plant litter without disturbing the soil surface. The calibration of the rainfall simulator to $360 \mathrm{~mm} \mathrm{~h}^{-1}$ intensity was done before the experiment started. The portable rainfall simulator was set up on the selected plot and the simulation was run for $5 \mathrm{~min}$. The rainfall simulator was surrounded with a metal frame such that all runoff water was collected at the lowest point. The collected runoff water, which contained the sediment, was brought to the laboratory, where it was oven-dried at $105^{\circ} \mathrm{C}$. The soil loss value $\left(\mathrm{kg} \mathrm{m}^{-2}\right)$ was converted to the interrill erosion rate $\left(D_{i}-\mathrm{kg} \mathrm{m}^{-2} \mathrm{~s}^{-1}\right)$, taking into account the average number of days with rainfall for a period of 30 years. The rainfall data were recorded at the nearest weather station of the experimental sites. The slope of each experimental plot was measured using a clinometer.

\subsubsection{Interrill and rill erodibility factors}

The actual interrill erodibility $\left(\mathrm{K}_{\mathrm{i}}\right)$ was estimated by the interrill erosion rate measured in the field and rainfall intensity calibrated to the site conditions with the rainfall simulator. Thus, the interrill erodibility parameter $\left(\mathrm{K}_{i}\right)$ was calculated using the interrill erosion rate $\left(D_{i}\right)$ as described by Elliot et al. (1989):

$$
K_{i}=\frac{D_{i}}{i^{2} * S_{f}}
$$


where $D_{i}$ is the interrill erosion rate $\left(\mathrm{kg} \mathrm{m}^{-2} \mathrm{~s}^{-1}\right)$ measured in the field, $\mathrm{K}_{\mathrm{i}}\left(\mathrm{kg} \mathrm{s} \mathrm{m}^{-4}\right)$ is the measured interrill erodibility calculated based on the measured field data; $\mathrm{i}\left(\mathrm{m} \mathrm{s}^{-1}\right)$ is the effective rainfall intensity, and $\mathrm{Sf}$ is the slope adjustment factor given by $\mathrm{S}_{f}=1.05-0.85 \mathrm{e}^{-}$ $0.85 * \sin (\theta)$, where $\theta$ is the slope of the surface, which is measured toward a nearby rill, and expressed in degrees.

The interrill and rill erodibility factors were predicted using the pedotransfer functions described in the Water Erosion Prediction Project (WEPP) model (Flanagan and Nearing, 1995). The WEPP model is applicable over a wide range of soil types and soil conditions to quantify the interrill and rill erosion (Flanagan and Nearing, 1995; Nearing et al., 2005). Based on field experiments and using the soil texture as the primary soil property, the interrill erodibility $\left(\mathrm{K}_{\mathrm{ib}}\right)$ was predicted for croplands with soils containing at least $30 \%$ sand (Elliot et al., 1989):

$K_{i b}=2728000+19210000 * V F S$

where $\mathrm{K}_{\mathrm{ib}}\left(\mathrm{kg} \mathrm{s} \mathrm{m}^{-4}\right)$ is the predicted interrill erodibility and VFS is the very fine sand fraction $(0.05$ to $0.15 \mathrm{~mm}$ ). If VFS is less than 0.40 , a value of 0.40 was used.

For soils containing less than $30 \%$ sand, equation (4) takes into account the fraction of clay:

$$
K_{i b}=6054000-5513000 * C L A Y
$$

The rill erodibility was predicted based on the soil properties, such as the soil organic matter (SOM), clay, and very fine sand (VFS) contents. The predicted rill erodibility $\left(\mathrm{K}_{\mathrm{rb}}\right)$ is determined using the pedo-transfer functions described in the WEPP model. The measured values for the SOM and the VFS were used. For soils containing $30 \%$ or more sand, the following was used (Elliot et al., 1989):

$$
K_{r b}=0.00197+0.030 * V F S+0.03863^{e-184^{*} S O M}
$$

where $\mathrm{K}_{\mathrm{rb}}\left(\mathrm{s} \mathrm{m}^{-1}\right)$ is the predicted rill erodibility. If VFS is less than 0.40 , a value of 0.40 for VFS was used.

For croplands with soils containing less than $30 \%$ sand:

$$
K_{r b}=0.0069+0.134^{e-20^{*} C L A Y}
$$




\subsubsection{Data analysis}

All data were subjected to normality and heterogeneity tests using the Shapiro-Wilk and Levene tests. A factorial two-way ANOVA was used to analyse significant differences between the treatments on the soil properties (i.e., BD, SOC, WAS) and soil erodibility (i.e., $\left.K_{i}, K_{i b}, K_{r b}\right)$ in the different sites. We assessed also the effects of interactions between the different treatments and the soil types at site location on the soil properties (i.e., BD, SOC, WAS) and soil erodibility.

Duncan's multiple range test was applied to compare the means for the different treatments and rank them in descending order. Principal Component Analysis (PCA) was conducted using CANOCO 5 statistical software to assess the effects of interactions between the factors on the soil properties and the soil erodibility. A pairwise correlation was performed to assess the relationship between variables and the degree of confidence of the predicted values.

\subsection{Results}

\subsubsection{Soil properties}

\subsubsection{Bulk density (BD)}

The application of mulch reduced significantly the BD after three years of application of 15 to $21 \mathrm{t} \mathrm{ha}^{-1}$ of the organic mulches at Kibirizi and Karongi $(P<0.001)$. At Kibirizi, T3, T4 and T5 showed significant lower bulk density values than the untreated control T6 $(P<0.001)$. At Karongi, low values of BD were observed in treatment T4. At Ruli, the treatments did not show significant effects on reduced $\mathrm{BD}$; the effects were comparable to the untreated control T6. The effects of the interactions between the mulching systems and the soil type were specific at each site $(P<0.05)($ Table 4.2$)$.

\subsubsection{Soil Organic Carbon (SOC)}

The application of mulch significantly increased the SOC after three years of application of the organic mulches at Kibirizi and Karongi $(\mathrm{P}<0.001)$. At Kibirizi, the SOC content ranged between 1.5 and 3.7\%. Treatments T5 and T4 showed significant high SOC values than the untreated control T6. At Karongi, the SOC was below 3\%; high SOC values were observed in treatment T4. At Ruli, the treatments did not show significant effects on the SOC content; the effects were more or less comparable to the untreated control (Table 4.2). 
Table 4.2 Effects of the mulching systems on Bulk Density (BD) $\left(\mathrm{g} \mathrm{cm}^{-3}\right)$, Soil Organic Carbon content (SOC) (\%) and Wet Aggregate Stability (WAS) index per study site

\begin{tabular}{|c|c|c|c|c|c|c|c|c|c|}
\hline \multirow[t]{2}{*}{ Treatment $^{1}$} & \multicolumn{3}{|c|}{ Kibirizi } & \multicolumn{3}{|c|}{ Karongi } & \multicolumn{3}{|c|}{ Ruli } \\
\hline & $\mathrm{BD}\left(\mathrm{g} \mathrm{cm}^{-3}\right)$ & SOC (\%) & WAS & $\mathrm{BD}\left(\mathrm{g} \mathrm{cm}^{-3}\right)$ & SOC (\%) & WAS & $\mathrm{BD}\left(\mathrm{g} \mathrm{cm}^{-3}\right)$ & SOC (\%) & WAS \\
\hline T1 & $1.37 \pm 0.10 a b^{2}$ & $2.63 \pm 0.26 b$ & $0.71 \pm 0.06 a$ & $1.37 \pm 0.20 \mathrm{ab}$ & $1.35 \pm 0.21 \mathrm{c}$ & $0.72 \pm 0.10 \mathrm{ab}$ & $1.28 \pm 0.15 a$ & $2.10 \pm 0.69 a$ & $0.20 \pm 0.01 b$ \\
\hline $\mathrm{T} 2$ & $1.31 \pm 0.11 b c$ & $2.09 \pm 0.18 b c$ & $0.56 \pm 0.07 c$ & $1.35 \pm 0.16 \mathrm{ab}$ & $1.45 \pm 0.33 c$ & $0.63 \pm 0.18 b$ & $1.20 \pm 0.06 a$ & $2.49 \pm 1.18 a$ & $0.17 \pm 0.01 c$ \\
\hline T3 & $1.20 \pm 0.09 \mathrm{~cd}$ & $2.34 \pm 0.72 b$ & $0.67 \pm 0.08 a b$ & $1.28 \pm 0.19 b c$ & $1.70 \pm 0.37 \mathrm{bc}$ & $0.60 \pm 0.26 b$ & $1.20 \pm 0.11 \mathrm{a}$ & $2.11 \pm 0.99 a$ & $0.14 \pm 0.02 d$ \\
\hline T4 & $1.13 \pm 0.06 d$ & $3.33 \pm 0.59 a$ & $0.61 \pm 0.05 b c$ & $1.13 \pm 0.08 d$ & $2.57 \pm 0.56 a$ & $0.86 \pm 0.08 a$ & $1.28 \pm 0.19 a$ & $1.86 \pm 0.73 a$ & $0.23 \pm 0.01 a$ \\
\hline T5 & $1.25 \pm 0.12 c$ & $3.72 \pm 0.52 \mathrm{a}$ & $0.72 \pm 0.06 a$ & $1.21 \pm 0.15 \mathrm{~cd}$ & $2.10 \pm 0.74 a b$ & $0.59 \pm 0.16 b$ & $1.20 \pm 0.09 a$ & $1.43 \pm 0.42 a$ & $0.20 \pm 0.02 b$ \\
\hline T6 & $1.45 \pm 0.05 a$ & $1.54 \pm 0.15 c$ & $0.38 \pm 0.04 d$ & $1.42 \pm 0.14 a$ & $1.22 \pm 0.35 c$ & $0.55 \pm 0.08 b$ & $1.15 \pm 0.05 a$ & $2.13 \pm 1.10 \mathrm{a}$ & $0.11 \pm 0.02 \mathrm{e}$ \\
\hline \multicolumn{10}{|c|}{ ANOVA (P-value $)^{3}$} \\
\hline Mulch & $<0.001$ & $<0.001$ & $<0.001$ & $<0.001$ & $<0.001$ & 0.006 & 0.174 & 0.368 & $<0.001$ \\
\hline Soil type & 0.057 & 0.785 & 0.001 & 0.001 & 0.167 & 0.331 & 0.147 & 0.008 & 0.089 \\
\hline Mulch*Soil & 0.606 & 0.743 & 0.048 & 0.001 & 0.868 & 0.109 & 0.019 & 0.534 & 0.004 \\
\hline
\end{tabular}

${ }^{1}$ Treatments as described in Table 4.1; $\mathrm{n}=36$;

${ }^{2}$ For each parameter, values in the same column with the same letter are not significantly different

${ }^{3}$ Values in bold are significant $(P<0.05)$. 
Table 4.3 Effects of the mulching systems on the measured interrill erodibility $\left(K_{i}\right)$, predicted interrill $\left(K_{i b}\right)$ and rill $\left(K_{r}\right)$ erodibility per study site

\begin{tabular}{|c|c|c|c|c|c|c|c|c|c|}
\hline \multirow[t]{2}{*}{ Treatment $^{1}$} & \multicolumn{3}{|c|}{ Kibirizi } & \multicolumn{3}{|c|}{ Karongi } & \multicolumn{3}{|c|}{ Ruli } \\
\hline & $\begin{array}{c}\mathrm{K}_{\mathrm{i}} \\
\left(\times 10^{5} \mathrm{~kg} \mathrm{~s} \mathrm{~m}^{-}\right. \\
\left.{ }^{4}\right)\end{array}$ & $\begin{array}{c}\mathrm{K}_{\mathrm{ib}} \\
\left(\times 10^{5} \mathrm{~kg} \mathrm{~s} \mathrm{~m}^{-}\right. \\
\left.{ }^{4}\right)\end{array}$ & $\begin{array}{c}\mathrm{K}_{\mathrm{rb}} \\
\left(\times 10^{-3} \mathrm{~s} \mathrm{~m}^{-1}\right)\end{array}$ & $\begin{array}{c}\mathrm{K}_{\mathrm{i}} \\
\left(\times 10^{5} \mathrm{~kg} \mathrm{~s} \mathrm{~m}^{-}\right. \\
\left.{ }^{4}\right)\end{array}$ & $\begin{array}{c}\mathrm{K}_{\mathrm{ib}} \\
\left(\times 10^{5} \mathrm{~kg} \mathrm{~s} \mathrm{~m}^{-}\right. \\
\left.{ }^{4}\right)\end{array}$ & $\begin{array}{c}\mathrm{K}_{\mathrm{rb}} \\
\left(\times 10^{-3} \mathrm{~s} \mathrm{~m}^{-1}\right)\end{array}$ & $\begin{array}{c}\mathrm{K}_{\mathrm{i}} \\
\left(\times 10^{5} \mathrm{~kg} \mathrm{~s} \mathrm{~m}^{-}\right. \\
\left.{ }^{4}\right)\end{array}$ & $\begin{array}{c}\mathrm{K}_{\mathrm{ib}} \\
\left(\times 10^{5} \mathrm{~kg} \mathrm{~s} \mathrm{~m}^{-}\right. \\
\left.{ }^{4}\right)\end{array}$ & $\begin{array}{c}\mathrm{K}_{\mathrm{rb}} \\
\left(\times 10^{-3} \mathrm{~s} \mathrm{~m}^{-1}\right)\end{array}$ \\
\hline T1 & $32.4 \pm 7.88 b^{2}$ & $49.4 \pm 3.56 b$ & $5.95 \pm 0.93 c$ & $54.5 \pm 28.7 a$ & $81.8 \pm 5.13 b$ & $11.1 \pm 0.97 a$ & $43.4 \pm 3.79 c$ & $56.3 \pm 4.63 \mathrm{bc}$ & $6.50 \pm 0.72 b c$ \\
\hline $\mathrm{T} 2$ & $26.2 \pm 5.49 c$ & $53.5 \pm 3.35 a$ & $9.09 \pm 1.50 a$ & $42.5 \pm 26.2 b$ & $76.2 \pm 16.8 \mathrm{~cd}$ & $10.3 \pm 3.39 a b$ & $46.7 \pm 2.43 b c$ & $62.6 \pm 5.04 b$ & $7.49 \pm 0.78 b$ \\
\hline T3 & $13.76 \pm 9.27 d$ & $24.5 \pm 1.38 d$ & $6.90 \pm 0.00 b$ & $46.7 \pm 21.4 a b$ & $87.1 \pm 4.59 a$ & $11.6 \pm 0.86 a$ & $49.2 \pm 6.88 b$ & $61.5 \pm 2.82 b$ & $7.33 \pm 0.44 b$ \\
\hline $\mathrm{T} 4$ & $4.95 \pm 3.58 \mathrm{e}$ & $35.6 \pm 12.1 \mathrm{c}$ & $5.20 \pm 1.86 d$ & $27.8 \pm 3.51 \mathrm{c}$ & $71.8 \pm 10.9 d$ & $8.95 \pm 1.69 c$ & $35.6 \pm 2.30 d$ & $50.5 \pm 4.79 c$ & $5.60 \pm 0.75 c$ \\
\hline T5 & $3.97 \pm 2.14 \mathrm{e}$ & $35.5 \pm 13.4 \mathrm{c}$ & $5.05 \pm 2.04 d$ & $19.5 \pm 8.30 d$ & $72.5 \pm 9.74 d$ & $9.30 \pm 1.58 \mathrm{bc}$ & $43.9 \pm 4.24 c$ & $57.4 \pm 8.02 b$ & $6.69 \pm 1.25 b$ \\
\hline T6 & $44.3 \pm 11.0 \mathrm{a}$ & $55.5 \pm 1.23 a$ & $9.56 \pm 0.72 a$ & $53.9 \pm 16.3 a$ & $80.5 \pm 4.17 b c$ & $11.5 \pm 1.26 a$ & $64.1 \pm 6.04 a$ & $75.5 \pm 3.07 a$ & $9.55 \pm 0.51 a$ \\
\hline \multicolumn{10}{|c|}{ ANOVA (P-value) ${ }^{3}$} \\
\hline Mulch & $<0.001$ & $<0.001$ & $<0.001$ & $<0.001$ & $<0.001$ & $<0.001$ & $<0.001$ & $<0.001$ & $<0.001$ \\
\hline Soil type & 0.151 & $<0.001$ & $<0.001$ & $<0.001$ & 0.003 & 0.008 & $<0.001$ & 0.197 & 0.232 \\
\hline Mulch*Soil & $<0.001$ & $<0.001$ & $<0.001$ & $<0.001$ & $<0.001$ & $<0.001$ & 0.021 & 0.550 & 0.505 \\
\hline
\end{tabular}

Explanation as in Table 4.2. 


\subsubsection{Wet Aggregate Stability index (WAS)}

The mulching systems showed significant effects on Wet Aggregate Stability $(P<0.001)$ (Table 4.2). At Kibirizi, the WAS ranged between 56 and $72 \%$ as compared to the un-treated control T6 (38\%); treatments T1 and T5 showed high WAS values. At Karongi, WAS values of the treatments varied between 59 and $86 \%$. The high WAS values were observed in treatment T4. At Ruli, the WAS values of the treatments were generally low, ranging below $23 \%$ (T4). The effects of the interactions between the mulching systems and the soil type were specific at each site $(P<0.05)$.

\subsubsection{Interrill and rill erodibility}

The mulching systems significantly reduced the interrill $\left(K_{i}\right.$ and $\left.K_{i b}\right)$ and rill erodibility $\left(K_{r b}\right)$ $(P<0.001)$. At Kibirizi, mulching with T4 and T5 reduced significantly the interrill erodibility ( $\mathrm{K}_{\mathrm{i}}$ ) up-to $91 \%$ as compared to the untreated control (T6). At Karongi, low values of the interrill erodibility $\left(\mathrm{K}_{\mathrm{i}}\right)$ were observed in treatment $\mathrm{T} 5$, which reduced the interrill erodibility $\left(\mathrm{K}_{\mathrm{i}}\right)$ by $64 \%$ as compared to the untreated control (T6). At Ruli, the interrill erodibility $\left(\mathrm{K}_{\mathrm{i}}\right)$ was reduced in $\mathrm{T} 4$ by $45 \%$ as compared to the untreated control (T6). The effects of the interactions between the mulching systems and the soil type were significant at each site $(P<0.05)$ (Table 4.3).

\subsubsection{Effects of interaction on soil properties}

The principal component analysis (PCA) showed significant interaction effects on soil properties. The effects of the interactions were site specific, and depended on the type of mulching materials, the soil texture and the agro-ecological conditions of the study site. At Kibirizi, the effects of $\mathrm{T} 1$ and $\mathrm{T} 2$ on bulk density were comparable to the untreated control T6, particularly on dominated sandy soils. Similar trends were also observed at Karongi (Fig 4.2). On the other hand, the effects of interactions between treatments T4 and/or T5 and the soil texture influenced increased soil organic carbon (SOC), particularly on clay and clayey loam soils, and thus, improved wet aggregate stability at Kibirizi and Karongi. Similar effects were not observed at Ruli; wet aggregate stability could have been affected by other factors rather than SOC (Fig 4.2).

The improvement in the soil aggregate stability following the application of T4 and T5 and the combined interaction effects of clay content in association with SOC significantly reduced the soil erodibility $\left(\mathrm{K}_{\mathrm{i}}\right)$ values. Such interaction effects were observed particularly at Kibirizi and Karongi; at these sites, the effects of interactions between T1 and/or T2 and 
the soil texture on soil erodibility were similar to the un-mulched control T6. In addition, the principal component analysis showed that the soil erodibility values were significantly related to the particle size distribution of the soils. Increasing the content of clay significantly decreased the soil erodibility rates; increasing the contents of sand and very fine sand (VFS) significantly increased the soil erodibility values at Kibirizi, whereas at Karongi, soil erodibility was positively affected by the contents of sand, and at Ruli by VFS (Fig 4.2).
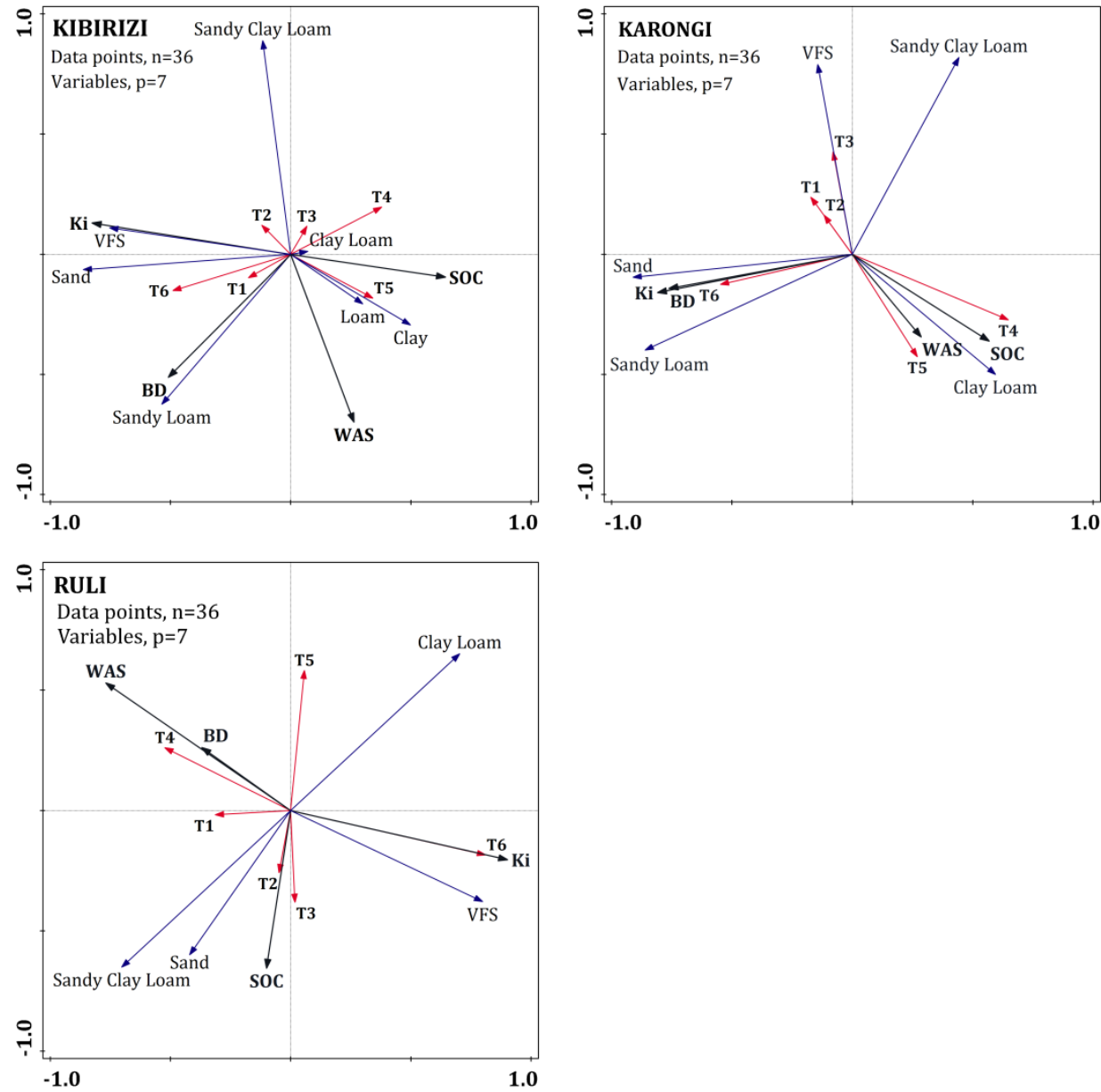

Figure 4.2 Principal Component Analysis of the interaction effects between mulching system, soil texture, sites (Karongi, Kibirizi and Ruli located in three different agro-ecological zones) and soil particle sizes on soil properties (B.D: Bulk density; SOC: Soil organic carbon; WAS: Wet aggregate stability index; Ki: Measured interrill erodibility; VFS: Very fine sand; T1 to T6 are the different treatments) 
Table 4.4 Pairwise Pearson correlation $(R)$ between the variables

\begin{tabular}{|c|c|c|c|c|c|c|c|c|c|c|c|c|c|c|c|c|c|c|}
\hline Variable & & \multirow{2}{*}{$\begin{array}{c}\begin{array}{c}\text { Yield } \\
\text { (t ha-1) }\end{array} \\
1\end{array}$} & \multicolumn{2}{|c|}{ Sand (\%) Clay (\%) } & \multirow{2}{*}{$\begin{array}{c}\begin{array}{c}\text { Silt } \\
(\%)\end{array} \\
-.211^{*}\end{array}$} & \multirow{2}{*}{$\begin{array}{c}\text { VFS (\%) } \\
.462^{* *}\end{array}$} & \multirow{2}{*}{$\begin{array}{c}\begin{array}{c}\mathrm{Sa}+\mathrm{Cl} \\
(\%)\end{array} \\
.216^{*}\end{array}$} & \multirow{2}{*}{$\begin{array}{c}\begin{array}{c}\mathrm{Sa}+\mathrm{Si} \\
(\%)\end{array} \\
.083\end{array}$} & \multirow{2}{*}{$\begin{array}{c}\text { Sa+VFS } \\
(\%) \\
.358^{* *}\end{array}$} & \multirow{2}{*}{$\begin{array}{c}\mathrm{Cl}+\mathrm{Si}(\%) \\
-.236^{*}\end{array}$} & \multirow{2}{*}{$\begin{array}{c}\begin{array}{c}\mathrm{Cl}+\mathrm{VFS} \\
(\%)\end{array} \\
.254^{* *}\end{array}$} & \multirow{2}{*}{$\begin{array}{c}\text { Si+VFS } \\
(\%) \\
.146\end{array}$} & \multirow{2}{*}{$\begin{array}{c}\text { OC } \\
(\%) \\
-.294^{* *}\end{array}$} & \multirow{2}{*}{$\begin{array}{c}\text { B.D } \\
\text { (g cm-3) } \\
-.024\end{array}$} & \multirow{2}{*}{$\begin{array}{c}\text { WAS } \\
.064\end{array}$} & \multirow{2}{*}{$\begin{array}{c}\mathrm{Ki} \\
.191^{*}\end{array}$} & \multirow{2}{*}{$\begin{array}{c}\mathrm{Kib} \\
.526^{* *}\end{array}$} & \multirow{2}{*}{$\begin{array}{c}\mathrm{Krb} \\
.483^{* *}\end{array}$} \\
\hline Yield & $\mathrm{R}$ & & $.242^{*}$ & -.079 & & & & & & & & & & & & & & \\
\hline$\left(\mathrm{t} \mathrm{ha}^{-1}\right)$ & Sig. & & .012 & .416 & .028 & .000 & .025 & .391 & .000 & .014 & .008 & .131 & .002 & .801 & .509 & .047 & .000 & .000 \\
\hline \multirow{2}{*}{ Sand (Sa) (\%) } & $\mathrm{R}$ & $.242^{*}$ & 1 & $-.786^{* *}$ & -.157 & $.666^{* *}$ & .162 & $.789^{* *}$ & $.948^{* *}$ & $-.994^{* *}$ & $-.552^{* *}$ & $.312^{* *}$ & $-.440^{* *}$ & $.396^{* *}$ & -.134 & $.659^{* *}$ & $.618^{* *}$ & $.517^{* *}$ \\
\hline & Sig. & .012 & & .000 & .105 & .000 & .094 & .000 & .000 & .000 & .000 & .001 & .000 & .000 & .165 & .000 & .000 & .000 \\
\hline \multirow{2}{*}{ Clay (CI) (\%) } & $\mathrm{R}$ & -.079 & $-.786^{* *}$ & 1 & $-.480^{* *}$ & $-.693^{* *}$ & $.483^{* *}$ & $-.995^{* *}$ & $-.817^{* *}$ & $.789^{* *}$ & $.825^{* *}$ & $-.762^{* *}$ & $.510^{* *}$ & $-.329^{* *}$ & .149 & $-.637^{* *}$ & $-.641^{* *}$ & $-.386^{* *}$ \\
\hline & Sig. & .416 & .000 & & .000 & .000 & .000 & .000 & .000 & .000 & .000 & .000 & .000 & .001 & .125 & .000 & .000 & .000 \\
\hline \multirow{2}{*}{ Silt (Si) (\%) } & $\mathrm{R}$ & $-.211^{*}$ & -.157 & $-.480^{* *}$ & 1 & .163 & $-.987^{* *}$ & $.483^{* *}$ & -.034 & .160 & $-.528^{* *}$ & $.785^{* *}$ & -.175 & -.062 & -.060 & .081 & .151 & -.119 \\
\hline & Sig. & .028 & .105 & .000 & & .091 & .000 & .000 & .727 & .098 & .000 & .000 & .071 & .527 & .538 & .407 & .120 & .220 \\
\hline \multirow{2}{*}{ VFS (\%) } & $\mathrm{R}$ & $.462^{* *}$ & $.666^{* *}$ & $-.693^{* *}$ & .163 & 1 & -.162 & $.692^{* *}$ & $.869^{* *}$ & $-.665^{* *}$ & -.163 & $.740^{* *}$ & $-.525^{* *}$ & $.231^{*}$ & -.062 & $.498^{* *}$ & $.919^{* *}$ & $.879^{* *}$ \\
\hline & Sig. & .000 & .000 & .000 & .091 & & .094 & .000 & .000 & .000 & .091 & .000 & .000 & .016 & .525 & .000 & .000 & .000 \\
\hline \multirow{2}{*}{$\begin{array}{c}\text { Sand+Clay } \\
(\%)\end{array}$} & $\mathrm{R}$ & $.216^{*}$ & .162 & $.483^{* *}$ & $-.987^{* *}$ & -.162 & 1 & $-.470^{* *}$ & .038 & -.147 & $.534^{* *}$ & $-.775^{* *}$ & $.190^{*}$ & .036 & .047 & -.083 & -.149 & .116 \\
\hline & Sig. & .025 & .094 & .000 & .000 & .094 & & .000 & .696 & .128 & .000 & .000 & .049 & .715 & .631 & .390 & .124 & .234 \\
\hline Candtcilt (os) & $\mathrm{R}$ & .083 & $.789^{* *}$ & $-.995^{* *}$ & $.483^{* *}$ & $.692^{* *}$ & $-.470^{* *}$ & 1 & $.819^{* *}$ & $-.781^{* *}$ & $-.818^{* *}$ & $.764^{* *}$ & $-.499^{* *}$ & $.313^{* *}$ & -.157 & $.635^{* *}$ & $.641^{* *}$ & $.384^{* *}$ \\
\hline San & Sig. & .391 & .000 & .000 & .000 & .000 & .000 & & .000 & .000 & .000 & .000 & .000 & .001 & .106 & .000 & .000 & .000 \\
\hline & $\mathrm{R}$ & $.358^{* *}$ & $.948^{* *}$ & $-.817^{* *}$ & -.034 & $.869^{* *}$ & .038 & $.819^{* *}$ & 1 & $-.943^{* *}$ & $-.436^{* *}$ & $.523^{* *}$ & $-.517^{* *}$ & $.361^{* *}$ & -.116 & $.650^{* *}$ & $.803^{* *}$ & $.719^{* *}$ \\
\hline 6) & Sig. & .000 & .000 & .000 & .727 & .000 & .696 & .000 & & .000 & .000 & .000 & .000 & .000 & .234 & .000 & .000 & .000 \\
\hline & $\mathrm{R}$ & $-.236^{*}$ & $-.994^{* *}$ & $.789^{* *}$ & .160 & $-.665^{* *}$ & -.147 & $-.781^{* *}$ & $-.943^{* *}$ & 1 & $.558^{* *}$ & $-.309^{* *}$ & $.452^{* *}$ & $-.413^{* *}$ & .125 & $-.661^{* *}$ & $-.616^{* *}$ & $-.518^{* *}$ \\
\hline & Sig. & .014 & .000 & .000 & .098 & .000 & .128 & .000 & .000 & & .000 & .001 & .000 & .000 & .197 & .000 & .000 & .000 \\
\hline & $\mathrm{R}$ & $.254^{* *}$ & $-.552^{* *}$ & $.825^{* *}$ & $-.528^{* *}$ & -.163 & $.534^{* *}$ & $-.818^{* *}$ & $-.436^{* *}$ & $.558^{* *}$ & 1 & $-.463^{* *}$ & $.286^{* *}$ & $-.269^{* *}$ & .155 & $-.482^{* *}$ & -.156 & .161 \\
\hline & Sig. & .008 & .000 & .000 & .000 & .091 & .000 & .000 & .000 & .000 & & .000 & .003 & .005 & .110 & .000 & .106 & .095 \\
\hline & $\mathrm{R}$ & .146 & $.312^{* *}$ & $-.762^{* *}$ & $.785^{* *}$ & $.740^{* *}$ & $-.775^{* *}$ & $.764^{* *}$ & $.523^{* *}$ & $-.309^{* *}$ & $-.463^{* *}$ & 1 & $-.449^{* *}$ & .103 & -.080 & $.368^{* *}$ & $.680^{* *}$ & $.471^{* *}$ \\
\hline $\mathrm{Sl}$ & Sig. & .131 & .001 & .000 & .000 & .000 & .000 & .000 & .000 & .001 & .000 & & .000 & .289 & .412 & .000 & .000 & .000 \\
\hline & $\mathrm{R}$ & $-.294^{* *}$ & $-.440^{* *}$ & $.510^{* *}$ & -.175 & $-.525^{* *}$ & $.190^{*}$ & $-.499^{* *}$ & $-.517^{* *}$ & $.452^{* *}$ & $.286^{* *}$ & $-.449^{* *}$ & 1 & $-.297^{* *}$ & $.192^{*}$ & $-.459^{* *}$ & $-.498^{* *}$ & $-.432^{* *}$ \\
\hline 0 & Sig. & .002 & .000 & .000 & .071 & .000 & .049 & .000 & .000 & .000 & .003 & .000 & & .002 & .047 & .000 & .000 & .000 \\
\hline B.D & $\mathrm{R}$ & -.024 & $.396^{* *}$ & $-.329^{* *}$ & -.062 & $.231^{*}$ & .036 & $.313^{* *}$ & $.361^{* *}$ & $-.413^{* *}$ & $-.269^{* *}$ & .103 & $-.297^{* *}$ & 1 & .135 & $.356^{* *}$ & .109 & $.258^{* *}$ \\
\hline$\left(\mathrm{g} \mathrm{cm}^{-3}\right)$ & Sig. & .801 & .000 & .001 & .527 & .016 & .715 & .001 & .000 & .000 & .005 & .289 & .002 & & .162 & .000 & .261 & .007 \\
\hline & $\mathrm{R}$ & .064 & -.134 & .149 & -.060 & -.062 & .047 & -.157 & -.116 & .125 & .155 & -.080 & $.192^{*}$ & .135 & 1 & $-.366^{* *}$ & -.066 & .092 \\
\hline & Sig. & .509 & .165 & .125 & .538 & .525 & .631 & .106 & .234 & .197 & .110 & .412 & .047 & .162 & & .000 & .495 & .344 \\
\hline $\mathrm{Ki}\left(\times 10^{5} \mathrm{~kg} \mathrm{~s}\right.$ & $\mathrm{R}$ & $.191^{*}$ & $.659^{* *}$ & $-.637^{* *}$ & .081 & $.498^{* *}$ & -.083 & $.635^{* *}$ & $.650^{* *}$ & $-.661^{* *}$ & $-.482^{* *}$ & $.368^{* *}$ & $-.459^{* *}$ & $.356^{* *}$ & $-.366^{* *}$ & 1 & $.530^{* *}$ & $.295^{* *}$ \\
\hline$\left.m^{-4}\right)$ & Sig. & .047 & .000 & .000 & .407 & .000 & .390 & .000 & .000 & .000 & .000 & .000 & .000 & .000 & .000 & & .000 & .002 \\
\hline Kib $\left(x 10^{5} \mathrm{~kg} \mathrm{~s}\right.$ & $\mathrm{R}$ & $.526^{* *}$ & $.618^{* *}$ & $-.641^{* *}$ & .151 & $.919^{* *}$ & -.149 & $.641^{* *}$ & $.803^{* *}$ & $-.616^{* *}$ & -.156 & $.680^{* *}$ & $-.498^{* *}$ & .109 & -.066 & $.530^{* *}$ & 1 & $.745^{* *}$ \\
\hline$\left.m^{-4}\right)$ & Sig. & .000 & .000 & .000 & .120 & .000 & .124 & .000 & .000 & .000 & .106 & .000 & .000 & .261 & .495 & .000 & & .000 \\
\hline Krb $\left(\times 10^{-3} \mathrm{~s}\right.$ & $\mathrm{R}$ & $.483^{* *}$ & $.517^{* *}$ & $-.386^{* *}$ & -.119 & $.879^{* *}$ & .116 & $.384^{* *}$ & $.719^{* *}$ & $-.518^{* *}$ & .161 & $.471^{* *}$ & $-.432^{* *}$ & $.258^{* *}$ & .092 & $.295^{* *}$ & $.745^{* *}$ & 1 \\
\hline $\left.\mathrm{m}^{-1}\right)$ & Sig. & .000 & .000 & .000 & .220 & .000 & .234 & .000 & .000 & .000 & .095 & .000 & .000 & .007 & .344 & .002 & .000 & \\
\hline
\end{tabular}

*. Correlation is significant at the $\mathrm{P}<0.05$ (2-tailed), $\mathrm{n}=108$; **. Correlation is significant at the $\mathrm{P}<0.01$ (2-tailed), $\mathrm{n}=108$ 
Table 4.5 Soil texture at the experimental sites

\begin{tabular}{|c|c|c|c|c|c|c|c|}
\hline \multirow[t]{2}{*}{ Treatment $^{1}$} & \multirow{2}{*}{$\begin{array}{c}\text { Particle size } \\
\text { (\%) }\end{array}$} & \multicolumn{3}{|c|}{ Inceptisols } & \multicolumn{3}{|c|}{ Ultisols } \\
\hline & & Kibirizi & Ruli & Karongi & Kibirizi & Ruli & Karongi \\
\hline \multirow[t]{4}{*}{ T1 } & Sand & $56.2 \pm 2.20^{2}$ & $53.6 \pm 0.58$ & $71.8 \pm 4.16$ & $38.1 \pm 1.72$ & $50.7 \pm 4.73$ & $48.5 \pm 1.16$ \\
\hline & Clay & $15.3 \pm 3.06$ & $25.7 \pm 1.16$ & $10.7 \pm 1.01$ & $19.7 \pm 5.86$ & $27.7 \pm 1.53$ & $27.1 \pm 3.69$ \\
\hline & Silt & $28.5 \pm 0.99$ & $20.7 \pm 0.58$ & $17.3 \pm 4.51$ & $42.2 \pm 7.15$ & $21.7 \pm 3.21$ & $24.4 \pm 4.84$ \\
\hline & Texture & Sandy loam & Sandy clay loam & Sandy loam & Loam & Sandy clay loam & Sandy clay loam \\
\hline \multirow[t]{4}{*}{$\mathrm{T} 2$} & Sand & $67.1 \pm 3.67$ & $55.7 \pm 1.53$ & $68.2 \pm 3.45$ & $45.7 \pm 4.15$ & $43 \pm 1.00$ & $56.2 \pm 11.70$ \\
\hline & Clay & $8.3 \pm 2.52$ & $24 \pm 1.00$ & $16.9 \pm 2.00$ & $17.3 \pm 5.03$ & $34.3 \pm 1.53$ & $24.1 \pm 2.73$ \\
\hline & Silt & $24.5 \pm 1.29$ & $20.3 \pm 1.53$ & $11.7 \pm 2.08$ & $36.9 \pm 1.03$ & $22.7 \pm 2.31$ & $19.8 \pm 12.58$ \\
\hline & Texture & Sandy loam & Sandy clay loam & Sandy loam & Loam & Sandy clay loam & Sandy clay loam \\
\hline \multirow[t]{4}{*}{ T3 } & Sand & $29.1 \pm 0.39$ & $54 \pm 1.73$ & $70.3 \pm 2.82$ & $27.2 \pm 3.19$ & $50.7 \pm 1.15$ & $49.7 \pm 5.42$ \\
\hline & Clay & $64.7 \pm 3.22$ & $23.3 \pm 2.52$ & $11.1 \pm 0.42$ & $66 \pm 2.00$ & $31 \pm 3.61$ & $28.5 \pm 3.16$ \\
\hline & Silt & $6.3 \pm 2.83$ & $22.7 \pm 1.15$ & $18.3 \pm 3.51$ & $6.7 \pm 1.79$ & $21.7 \pm 5.13$ & $22.2 \pm 6.75$ \\
\hline & Texture & Clay & Sandy clay loam & Sandy loam & Clay & Sandy clay loam & Sandy clay loam \\
\hline \multirow[t]{4}{*}{ T4 } & Sand & $24.7 \pm 2.34$ & $53.7 \pm 2.08$ & $47.4 \pm 2.91$ & $31.6 \pm 1.17$ & $48 \pm 1.00$ & $38.8 \pm 3.28$ \\
\hline & Clay & $65 \pm 3.61$ & $21.7 \pm 2.08$ & $26.6 \pm 4.36$ & $23.3 \pm 1.16$ & $32 \pm 2.00$ & $31.8 \pm 2.54$ \\
\hline & Silt & $10.3 \pm 1.44$ & $24.7 \pm 2.08$ & $26 \pm 2.00$ & $45.07 \pm 2.17$ & $19.3 \pm 0.58$ & $29.3 \pm 2.89$ \\
\hline & Texture & Clay & Sandy clay loam & Sandy clay loam & Loam & Sandy clay loam & Clay loam \\
\hline \multirow[t]{4}{*}{ T5 } & Sand & $63.1 \pm 1.45$ & $54.7 \pm 1.53$ & $76.5 \pm 1.15$ & $41.6 \pm 5.62$ & $42.3 \pm 1.53$ & $73.3 \pm 0.32$ \\
\hline & Clay & $8.7 \pm 1.16$ & $22 \pm 1.00$ & $8.9 \pm 0.00$ & $12.7 \pm 2.08$ & $30.7 \pm 2.08$ & $13.1 \pm 2.04$ \\
\hline & Silt & $28.2 \pm 0.62$ & $23.3 \pm 1.53$ & $14.7 \pm 1.15$ & $45.8 \pm 4.31$ & $27 \pm 2.00$ & $13.3 \pm 2.31$ \\
\hline & Texture & Sandy loam & Sandy clay loam & Sandy loam & Loam & Clay loam & Sandy loam \\
\hline \multirow[t]{4}{*}{ T6 } & Sand & $27.1 \pm 2.24$ & $56.7 \pm 1.53$ & $68.2 \pm 2.54$ & $30.7 \pm 1.12$ & $43.7 \pm 0.58$ & $37.6 \pm 5.69$ \\
\hline & Clay & $67.3 \pm 1.16$ & $21 \pm 1.00$ & $20.9 \pm 2.31$ & $47 \pm 1.00$ & $30.7 \pm 0.58$ & $30.7 \pm 1.57$ \\
\hline & Silt & $5.6 \pm 1.43$ & $22.3 \pm 1.53$ & $14.7 \pm 1.15$ & $22 \pm 2.00$ & $25.7 \pm 0.58$ & $31.4 \pm 6.40$ \\
\hline & Texture & Clay & Sandy clay loam & Sandy loam & Clay & Clay loam & Clay loam \\
\hline
\end{tabular}

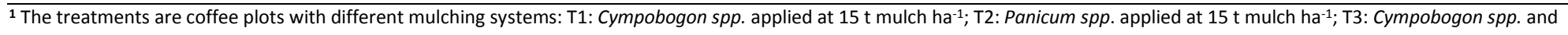

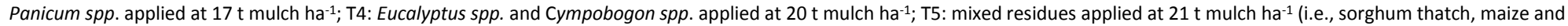
beans residues, banana leaves, Eucalyptus leaves and branches, Panicum spp., and sugar cane); T6: un-mulched coffee used as control with $0 \mathrm{t}$ mulch ha-1. ${ }^{2}$ Standard deviation ( $\mathrm{n}=108$ ). 


\subsection{Discussion}

The increased bulk density (BD) could be related to the soil porosity following the increased in the soil organic carbon (SOC) ( $R=-0.297^{* *}$ ) (Table 4.4). The SOC content can be increased by incorporating mulch into the soil, and this process can influence the BD by increasing the total soil porosity (Kong et al., 2005; Mulumba and Lal, 2008; Pimentel et al., 1995). The high BD values of the un-mulched control could be related to the reduced soil porosity that has resulted from detached finer soil particles, which were transported through the overland flow, and subsequently they may have clogged the pores, and sealed the soil surface (Jordán et al., 2010).

In addition, bulk density and SOC differed by the mulching system (i.e. type of mulch and application rate) and the soil texture. The high BD values were observed at T1, T2 and T6 on dominated sandy soils (Table 4.5). The type of mulches applied as T1 (Cympobogon spp.) and T2 (Panicum spp.) at $15 \mathrm{t}$ mulch ha-1 did not contribute to the increase in SOC, although they supplied a high organic content $(>1.7 \%)$; this effect could probably be related to their slow rate of mineralisation (Lugato and Berti, 2008; Simonsky et al., 2013) or to the leaching character of the sandy soils of the treatments. In addition, the SOC increased in clay $\left(\mathrm{R}=0.510^{* *}\right)$ and loamy soils $\left(\mathrm{R}=-0.499^{* *}\right)$ compared to the other soil textures, which may be related to the formation of organo-clay complexes that decrease the decomposition rates (Pavan et al., 1999; Smith et al., 2000; Tejada and Gonzalez, 2007, 2008). The association of SOC with clay and silt particles could be related to the amount of organic carbon that can mobilise to saturate the clay and silt fractions on a particular soil texture for different mulch types (Hassink, 1997).

Furthermore, the variations in the BD and SOC were also site-specific due probably to the effects of micro-climate of the study sites on mulch decay. The three study sites show different agro-ecological conditions that might induce the mineralization of the applied mulching materials. For instance at Ruli, the humid climatic conditions and excess rainfall of its high altitude contributed probably to the immobilization of microbes that induced slow decomposition of the mulches, and thus, slowed the rate of mineralization of $\mathrm{C}$ and $\mathrm{N}$ (Palm et al., 2001). These conditions resulted in low SOC that affected negatively the BD (Rsoc-BD= $-0.297^{* *}$ ) and WAS (Rsoc-WAS $\left.=0.135\right)$.

Furthermore, the high WAS index usually indicates an improvement in the macroaggregation processes that increase the soil stability, reduce the soil disturbance, increase the soil infiltration capacity, and thus increase the soil resistance to detachment by overland flow (Kong et al., 2005; Mulumba and Lal, 2008; Pimentel et al., 1995). Generally, the increased stability of the soil aggregates is related to the content of humic acid components 
in the applied organic materials (Tejada and Gonzalez, 2007, 2008). Our results showed that an increase in the SOC content after mulching did not directly stabilise the soil; the stabilisation was indirectly more influenced by other factors, such as the soil texture (RsocClay $=0.510^{* *}$; Rsoc-wAS $=0.192 * *$ ). Annabi et al. (2011) discussed also extrinsic factors such as climatic variables and agricultural practices like organic amendment applications that influence the soil aggregate stability.

In addition, our results showed that low SOC and WAS values coincides with high values of the interrill ( $\mathrm{Rsoc}-\mathrm{ki}=-0.459 * *)$ and rill erodibility $(\mathrm{Rsoc}-\mathrm{kr}=-0.432 * *)$. This demonstrated the indirect influence of the quality of mulching materials that can be applied to control soil erosion by water and soil aggregate stability in mountain coffee farming systems. The high interrill erodibility was related to finer soil particles, mainly very fine sand ( $R_{\mathrm{Ki}-\mathrm{VFs}}=0.498^{* *}$ ), which resulted from the detached soil particles of weak soil aggregates. These particles might have been then transported due to the increased overland flow to reduce the water infiltration capacity, which increased the interrill erodibility (Arthur et al., 2011; Blavet et al., 2009; Wuddivira et al., 2013). Sandy and silty soils (i.e., silt, silty loam, loam, silt clay loam) were highly vulnerable to soil erosion by water (Bonilla and Johnson, 2012; Duiker et al., 2001; Romero et al., 2007; Zhang et al., 2004). The mulching systems applied on clayey soils favoured the resistance of soil particle detachment by overland flow, and thus showed low interrill erodibility rates $\left(\mathrm{R}_{\mathrm{ki} \text {-Clay }}=-0.637^{* *}\right)$. This could again be explained by the association of the organic components and clay particles that formed stable organo-clay complexes that increased the stability of the soil aggregates. This stability then increased the soil resistance to the breakdown of soil aggregates (Kong et al., 2005; Mulumba and Lal, 2008; Pimentel et al., 1995). Hence, the soil erodibility values were not only influenced by the SOC contents supplied by various mulching systems as well as the soil texture influenced the soil erodibility values.

Besides, the predicted interrill erodibility $\left(K_{i b}\right)$ values were higher than the measured values $\left(K_{i}\right)$, and the difference is comparable to the data reported by Romero et al. (2007). Both the measured $(\mathrm{Ki})$ and predicted values $\left(\mathrm{K}_{\mathrm{ib}}\right.$ and $\left.\mathrm{K}_{\mathrm{rb}}\right)$ are higher than those reported by Zehetner and Miller (2006). The pedo-transfer functions validated the measured $K_{i}$ values for the prediction of the interrill $\left(\mathrm{R}_{\mathrm{Ki} \text {-Kib }}=0.53^{* *}\right)$ and rill soil erodibility $\left(\mathrm{R}_{\mathrm{Ki}-\mathrm{Kr}}=0.295^{* *}\right)$. The soil texture significantly influenced the interrill and rill erodibility values, and increasing the clay content significantly decreased the soil erodibility values $\left(\mathrm{R}_{\mathrm{ki} \text {-Clay }}=-0.637^{* *}\right)$, while high interrill and rill erodibility values were observed for soils with high sand $\left(\mathrm{R}_{\mathrm{Ki} \text {-Sand }}=0.659 * *\right.$; $\left.\mathrm{R}_{\mathrm{kr}-\mathrm{Sand}}=0.517^{* *}\right)$. The interrill erodibility was high on sandy loam soils as was also reported by other researchers (Bonilla and Johnson, 2012; Duiker et al., 2001; Lal and Elliot, 1994; Romero et al., 2007). 


\subsection{Conclusions}

- Mulching demonstrated positive effects on soil properties and soil erodibility, specifically at Karongi and Kibirizi. Thus, the effects were site specific, depending on the agro-ecological conditions of the study sites and the types of mulch used in coffee farming systems of Rwanda mountainous landscape;

- The application of mixed crop residues as mulch contributed specifically to improve soil properties and to reduce significantly the erodibility at all sites as compared to the other type of mulches. In addition, the erodibility was also influenced by high contents of sand and very fine sand fractions in the soils;

- In Rwanda, coffee is mostly farmed on coarse-textured soils that are characterized by low soil stability. We recommend mulching to control their leaching behaviour, and this would contribute to improve soil conditions and hence, coffee productivity. 


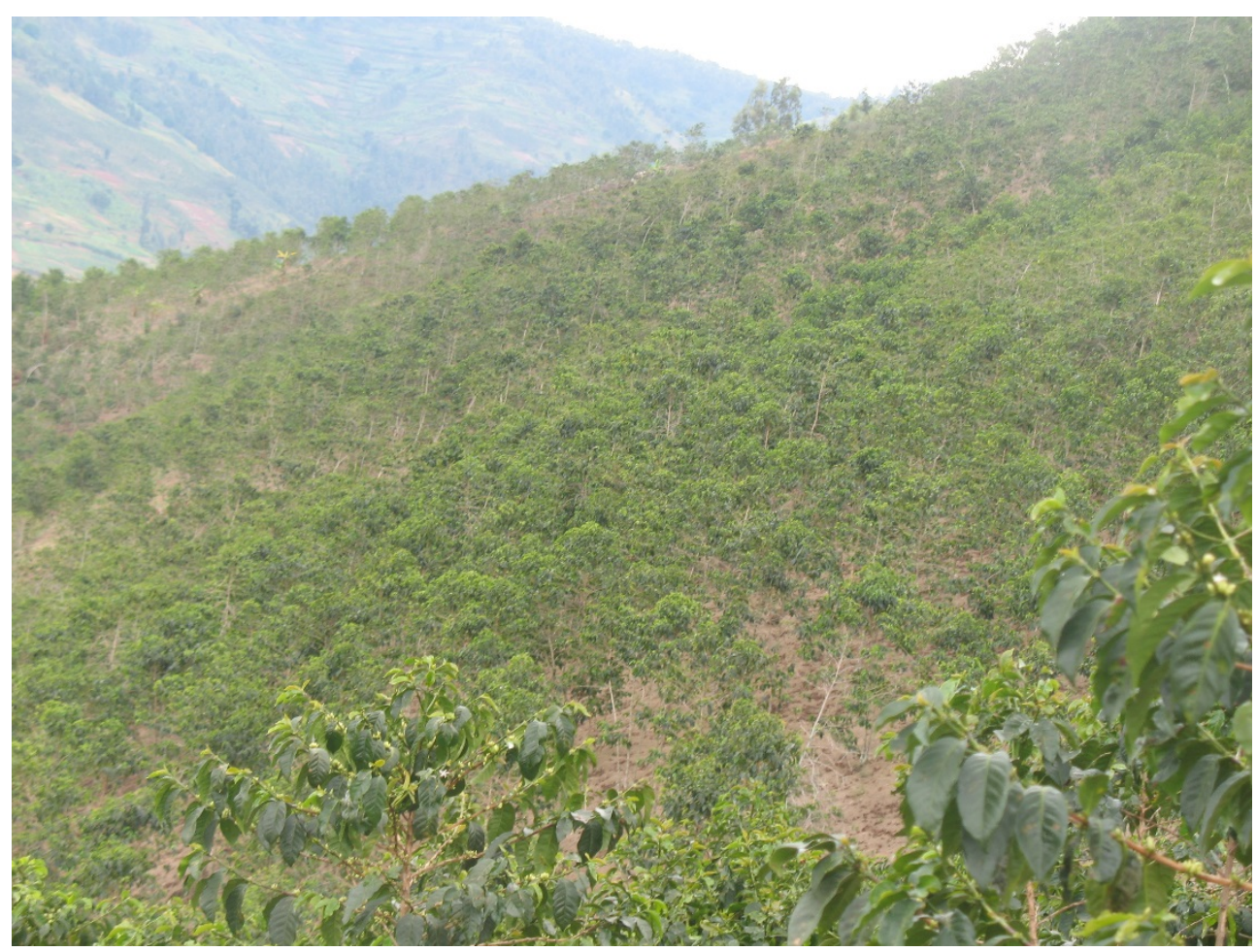




\section{Mulching effects on soil nutrient levels and yield of coffee farms in Rwanda}

Different combinations of organic mulch were applied in smallholder coffee farming system to assess the effects on soil nutrient availability and coffee yield. Mulching systems consisted of $T 1$ (Cymbopogon spp. at $15 t$ mulch ha ${ }^{-1}$ ), T2 (Panicum spp. at $15 t$ mulch ha ${ }^{-1}$ ), T3 (Cymbopogon spp. and Panicum spp. at $17 t$ mulch ha ${ }^{-1}$ ), T4 (Eucalyptus spp. and Cymbopogon spp. applied at 20 t mulch ha ${ }^{-1}$ ), T5 (mixed residues applied at 21 t mulch ha ${ }^{-1}$ ) and T6 (un-mulched coffee used as control with $0 t$ mulch $h^{-1}$ ). The effects of the mulching systems on soil $\mathrm{pH}$, organic $\mathrm{C}$, major soil nutrient content and on coffee yield were measured and assessed at three sites of different agro-ecological zones, namely, Kibirizi, Karongi, and Ruli. Mulch had significant and specific effects at each site $(P<0.001)$. T3 reduced soil $p H$ value and exchangeable acidity at Kibirizi, while at Karongi and Ruli, these effects were observed with T4 and T5. T4 and T5 increased significantly the contents of soil C, N, P, K, Ca and $\mathrm{Mg}$ levels. The increased soil nutrient levels led to improved soil fertility conditions and increased coffee yields. The amount of nutrient contents released was regulated by the amount of mulch applied, the type of mulch used, the agro-ecological conditions and the soil properties at each site. Mulching with mixed crop residues was the major source of soil nutrients and increased coffee yield. The coffee yield was significantly increased with T1 at Karongi $(P<0.05)$, whereas at Kibirizi, T2 and T3 showed significant higher yields. Coffee yields at Kibirizi were $48 \%$ lower compared to yields at Karongi. The amount of nutrient contents released during mulch decomposition and the coffee yield were regulated by the amount of mulch biomass applied, the quality and type of mulch used, and the agroecological conditions of the specific study site. Although the mulch improved coffee yield and soil conditions, coffee yield over $1.9 t h^{-1}$ could only be obtained with combination of inorganic fertilizer used at different rates at each agro-ecological zone and soil type.

Innocent Nzeyimana, Alfred E. Hartemink, Coen J. Ritsema, Jean Jacques M. Mbonigaba, Violette Geissen. 2018. Mulching effects on soil nutrient levels and yield of coffee farms in Rwanda.

Submitted to Soil Use and Management. 


\subsection{Introduction}

Soils in the tropics that are not well managed are subject to degradation following loss of soil organic matter, soil fertility decline and accelerated soil erosion compared to natural ecosystems (Bot and Benites, 2005; Hartemink, 2006). It is generally perceived that soil management is improved under permanent cropping systems with perennials or when cash crops are grown. In Rwanda, coffee (Coffea arabica L.) is grown by smallholder farmers on plots scattered on hillsides at elevation between $1,400 \mathrm{~m}$ asl in the Central Plateau and Mayaga, and above 2,000 $\mathrm{m}$ asl in the highlands. Mulching is used in coffee smallholder farming to improve soil fertility conditions and coffee yield. Mulching is an age-old agronomic practice, universally practiced to improve the soil moisture (Murungu et al., 2011; Wu et al., 2016), to reduce soil temperature (Kosterna, 2014; Wu et al., 2016), to decrease evaporation (Shen et al., 2015), to suppress weed growth (Manjith and Angadi, 2016; Thankamani et al., 2016), to reduce soil losses (Nzeyimana et al., 2017) and improve soil fertility (Liu et al., 2017; Mwango et al., 2016; Prosdocimi et al., 2016a; Prosdocimi et al., 2016b). Most smallholder farmers are faced with challenges of low levels of crop yields as a result of lack of nutrient inputs and soil nutrient depletion (Moebius-Clune et al., 2011; Sanchez, 2015). Mulching is adopted by the smallholder farmers as one of the land management technologies to maintain or restore soil fertility (Liu et al., 2017; Mwango et al., 2016; Ni et al., 2016).

Soil nutrient levels increases with higher mulch applications (Adekiya et al., 2017; Agbede et al., 2014; Fang et al., 2008; Mulumba and Lal, 2008), leading to improved soil fertility and crop productivity (Liu et al., 2017; Okeyo et al., 2014; Tao et al., 2015). Different mulches have different effects in supplying nutrient contents to soils; variations depending on quality of mulching materials, climatic conditions and soil types (Awopegba et al., 2017; Daraghmeh et al., 2009; Okur et al., 2016). Mulching with crop residues was reported as a major source of soil nutrients to improve efficiently the soil fertility. For instance, mulches from straw have the potential to increase concentrations of soil organic $\mathrm{C}, \mathrm{N}$, and $\mathrm{K}$ in the topsoil (Foshee et al., 1999; Stagnari et al., 2014), whereas legume mulch materials like Pueraria phaseoloides, Mucuna pruriens, Chromolaena odorata and Tithonia diversifolia produced higher concentrations of soil organic $\mathrm{C}$, total $\mathrm{N}$, available $\mathrm{P}$, exchangeable $\mathrm{K}, \mathrm{Ca}$ and $\mathrm{Mg}$ compared to grass mulch materials like Pennisetum purpureum, Panicum maximum and fresh cogon grass. The values of these concentrations increased with increasing mulch rate (Adekiya et al., 2017; Agbede et al., 2014). Mulches from maize residues are often classified of poor quality whereas it is a widely available type in Sub-Saharan Africa (Vanlauwe et al., 2006). 
Coffee is an important cash and export crop in the highlands of the East and central African countries (e.g. Rwanda, Uganda, Tanzania, Kenya, Ethiopia, and Burundi). Poor soil fertility status and poor mulching are the major constraints to coffee production in the region (Wairegi and van Asten, 2012; Wairegi et al., 2014; Wang et al., 2015). Nitrogen (N) is often the most limiting factor in coffee production, whereas Phosphorus $(P)$ is the second (Bote et al., 2018). Annual Nitrogen uptake by coffee plant has been estimated at 30 to $40 \%$ of the applied $\mathrm{N}$ (Bruno et al., 2015). In coffee farming, $\mathrm{N}$ is usually supplied through inorganic or organic (i.e. mulching) fertilization. Low quality mulch (high $\mathrm{C} / \mathrm{N}$ ) might result in $\mathrm{N}$ deficiency (Schluter and Finney, 2000). Commonly, N mineralization proceeds more rapidly in residues with a low $\mathrm{C} / \mathrm{N}$ ratio (Nikolaidou et al., 2010). Mulching with multipurpose legumes has been proven as an option for providing $\mathrm{N}$ to coffee and increasing productivity in Rwanda coffee farming systems (Bucagu et al., 2013). Due to scarcity of legume mulch materials, mono-crop coffee farmers use low quality mulch materials like Hyparrhenia spp., Eragrostis spp., Panicum spp., Pennisetum purpureum, Panicum maximum, Cymbopogon spp., Grevillea and Eucalyptus branches or a mix of crop residues like maize, sorghum thatches and banana leaves (Bucagu et al., 2013; Jassogne et al., 2013; Nzeyimana et al., 2013). The production of quality mulching materials requires additional land, which is scarce in Rwanda. The use of inorganic fertilizers is an alternative, which is limited by its high cost (Bruno et al., 2015; Jassogne et al., 2013). In the absence of fertilizer use, smallholder farmers rely on organic mulch residues to maintain the soil fertility (Vanlauwe et al., 2006). The amount of nutrients released is mainly regulated by the mulch biomass loaded (Adekiya et al., 2017), the residue chemical composition, the climatic conditions and soil types (Sariyildiz and Anderson, 2003).

Mulch may lead to a reduction in the amount of inorganic fertilizers needed to obtain high yields (Kwabiah et al., 2003). Depending on the coffee variety, yields are estimated at 1.4, $0.6,0.3$ and $0.5 \mathrm{t} \mathrm{ha}^{-1}$ of green coffee in Brazil, Colombia, Kenya and Rwanda, respectively (FAO, 2014). In Uganda, arabica coffee yields vary between 0.2 and $2.2 \mathrm{t}$ of green coffee $\mathrm{ha}^{-1}$ year $^{-1}$ (Wang et al., 2015); on smallholder farms (in Uganda), coffee yield averages about $0.8 \mathrm{t}$ of green coffee ha ${ }^{-1}$ year $^{-1}$, with a soil nutrient budget removal of about $105 \mathrm{~kg}$ $\mathrm{N} \mathrm{ha}^{-1}, 13 \mathrm{~kg} \mathrm{P} \mathrm{ha}^{-1}, 107 \mathrm{~kg} \mathrm{~K} \mathrm{ha}^{-1}$ (Van der Vossen, 2005). On similar soil, Nair (2010) estimated a withdrawal of approximately $64 \mathrm{~kg} \mathrm{~N}, 12 \mathrm{~kg} \mathrm{P}$ and $87 \mathrm{~kg} \mathrm{~K}$ removed to produce a ton of coffee beans. Coffee yields are limited by low soil fertility and the lack of inputs in Rwanda. Potassium and $\mathrm{N}$ deficiencies are mainly observed on acidic and on degraded soils, whereas they are key nutrients for high yielding coffee (Cordingley, 2009).

Data on the effectiveness of mulch in improving soil fertility and coffee yield is scarce in the Rwanda highlands despite the importance of the crop for most smallholders. The objectives of the present study were: (a) to assess the effects of the different organic mulches applied 
in coffee production systems on soil fertility in different agro-ecological zones of Rwanda highlands; (b) to assess the effect of different mulching systems on coffee yields.

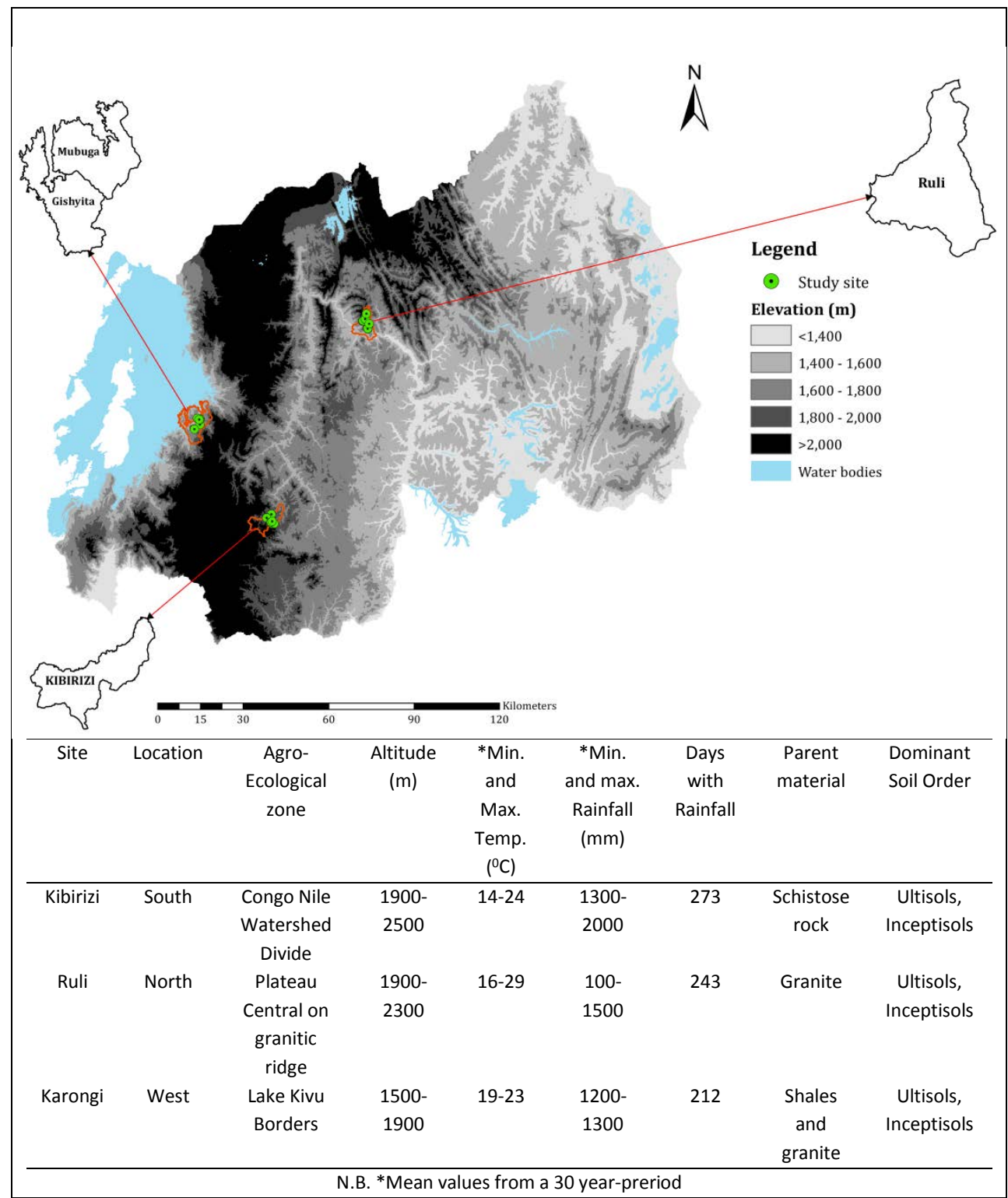

Figure 5.1 Map of Rwanda with the locations of the three study sites (Kibirizi, Karongi and Ruli) 


\subsection{Materials and Methods}

\subsubsection{Site description}

The study sites were located in Kibirizi Sector of Nyamagabe District in the Southern Province, Ruli Sector of Gakenke District in the Northern Province, and Gishyita-Mubuga Sectors of Karongi District in the Western Province (Fig 5.1). The sites are located in three agro-ecological zones (AEZ). Kibirizi is in the cold and humid southern highlands at the Congo-Nile Watershed Divide AEZ, with altitudes varying between 1,900 and 2,500 m a.s.l.; the annual minimum and maximum temperatures average between 14 and $24^{\circ} \mathrm{C}$, and the annual rainfall averages between 1,300 and 2,000 $\mathrm{mm}$. The soils varied between sandy loam, loam and clayey soils, but they were mainly dominated by clayey soils and clayey loam derived from schistose materials. The soils were classified as Ultisols and Inceptisols and acidic with low nutrient availability (Birasa et al., 1990).

The Ruli site is located in the cold and humid northern highlands at the Central Plateau and granitic ridges, at elevation between 1,900 and 2,300 $\mathrm{m}$ a.s.l.; the annual temperatures vary between 16 and $29^{\circ} \mathrm{C}$, and the annual rainfall varies between 1,100 and 1,500 mm. The soils are dominated by sandy clay loam and sandy loam soils developed from granite and are mainly classified as Inceptisols, Ultisols and Alfisols (Birasa et al., 1990). The Karongi site is located in the western middle altitude with a cool climate of the Lake Kivu shores, and the soils are dominated by sandy clay loam and sandy loam soils derived from shales and granites. These soils are mainly classified as Inceptisols and Ultisols (Birasa et al., 1990). Except for the abrupt slopes that are eroded, the level of soil fertility is moderate. The altitude varies between 1,500 and $1,900 \mathrm{~m}$; the annual rainfall and temperature vary from 1,200 to $1,300 \mathrm{~mm}$ and from 19 to $22.5^{\circ} \mathrm{C}$, respectively (Gasana, 1991; Verdoodt and Van Ranst, 2003).

\subsubsection{Field Experimental Design}

Field experiments were carried out from 2007 to 2009. The treatments (five mulching systems + control) were selected in coffee plantations to which the same mulch material had been applied annually at an average rate of 15 to $21 \mathrm{t} \mathrm{ha}^{-1}$ for at least three consecutive years before we started field experiments in 2007. The experimental design consisted of a randomized complete bloc design (RCBD) of six treatments replicated on two soil types (i.e., Inceptisols and Ultisols) at three sites (i.e. Kibirizi, Ruli and Karongi) (Table 5.1); site location being the main factor. The treatments were replicated three times at each site. The five mulching systems were selected from the most dominant mulching material used in coffee 
plantations by smallholder farmers. In Rwandan coffee farming system, organic mulch is annually applied from January to March and from July to September, just before the heavy rains and the dry season of July to August.

In addition, the selection of the coffee plantations took into account a mulch cover exceeding $75 \%$ and a slope gradient between 25 and 35\%. The amount and thickness of the applied mulch were measured using $1 \mathrm{~m}^{2}$ metal frame, and the percentage of the soil cover was estimated (Table 5.1). All of the selected experimental plots received $200 \mathrm{~kg} \mathrm{ha}^{-1} \mathrm{yr}^{-1}$ of NPK (20-10-10) applied around the coffee stem two years prior to soil sampling. This is periodically applied to return nutrients removed through parchment, pulp, coffee beans, erosion, leaching and pruning. The size of each experimental plot was $10 \times 10 \mathrm{~m}$, and each plot contained 25 coffee trees (i.e., 2500 trees per ha) spaced $2 \mathrm{~m}$ apart. The coffee trees were 20 to 25 years of age, and cropped as pure-stand monoculture system.

Table 5.1 Description of the mulching systems (treatments) applied in coffee plots by smallholder farmers in Rwanda

\begin{tabular}{cccc}
\hline Treatment $^{1}$ & Mulching system ${ }^{2}$ & $\begin{array}{c}\text { Amount of mulch } \\
\text { application } \\
\text { (t mulch ha }^{-1} \text { ) }\end{array}$ & $\begin{array}{c}\text { Mulch } \\
\text { thickness (mm) }\end{array}$ \\
\hline T1 & Cymbopogon spp. & 15 & 22 \\
T2 & Panicum spp. & 15 & 20 \\
T3 & Cymbopogon spp. mixed with Panicum spp. & 17 & 31 \\
T4 & Eucalyptus spp. mixed with Cymbopogon spp. & 40 \\
T5 & Mixed residues (i.e., sorghum thatch, maize and beans & 20 & 41 \\
& residues, banana leaves, Eucalyptus leaves and branches, & & 0 \\
T6 & Panicum spp., sugar cane) & & \\
\hline
\end{tabular}

N.B. ${ }^{1}$ The treatments are coffee plots with different mulching systems: T1: Cymbopogon spp. applied

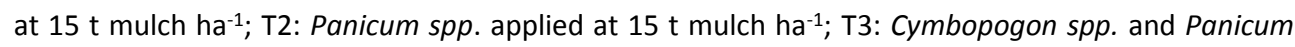
spp. applied at $17 \mathrm{t}$ mulch ha-1; T4: Eucalyptus spp. and Cymbopogon spp. applied at $20 \mathrm{t}$ mulch ha-1; T5: mixed residues applied at $21 \mathrm{t} \mathrm{mulch} \mathrm{ha-1}^{-1}$ (i.e., sorghum thatch, maize and beans residues, banana leaves, Eucalyptus leaves and branches, Panicum spp., and sugar cane); T6: un-mulched coffee used as control with 0 t mulch ha-1;

${ }^{2}$ Mulching systems selected from the most dominant mulching material used in coffee plantations by smallholder farmers in Rwanda. The mulching systems were selected in coffee plantations to which the same mulch material had been applied annually at an average rate of $15-21 \mathrm{t}$ mulch ha-1 for at least three consecutive years before we started field experiments in 2007, and during the field experimentation period, i.e. from 2007 to 2009 . The amount and thickness of the applied mulch were measured using $1 \mathrm{~m}^{2}$ metal frame, and the percentage of the soil cover was estimated. 


\subsubsection{Soil sampling and analysis}

Composite soil samples $(0-20 \mathrm{~cm})$ were taken between coffee rows at the intersections of cross-diagonals of 4 trees using a $7 \mathrm{~cm}$ Edelman auger. The soil samplings were taken in September 2008, and after 3 years of application of the mulches. Mulch and crop residues were removed from the soil surface before sampling. The composite samples were from 10 spots per plot mixed in a bucket. The samples were analysed for the following properties: particle size distribution, soil $\mathrm{pH}$, organic carbon, calcium (Ca), magnesium (Mg), potassium $(\mathrm{K})$, available phosphorus, total nitrogen $\left(\mathrm{N}_{\text {tot }}\right)$, sodium $(\mathrm{Na})$, exchangeable aluminum (Al), and cation exchange capacity (CEC). The analytical methods are described in the manual for laboratory methods by Okalebo et al. (2002).

\subsubsection{Mulch sampling and analysis}

In order to capture and evaluate nutrient concentrations in the mulch, sampling was conducted in September 2008 before the soil sampling. To analyze the dry matter and nutrients content, 10 spots of litter were taken randomly using a $1 \mathrm{~m}^{2}$ frame placed in each replicate, and mixed in a bucket to make a composite sample of $0.5 \mathrm{~kg}$. The litter samples were oven-dried at $60^{\circ} \mathrm{C}$ to constant weight, weighed, and grounded. Total $\mathrm{N}$ was analysed after Kjeldahl digestion, available $\mathrm{P}$ using the ascorbic acid method and $\mathrm{K}$ was analysed by flame photometry. The $\mathrm{Ca}$ and $\mathrm{Mg}$ levels were determined using atomic absorption spectrometry (Anderson and Ingram, 1993; Okalebo et al., 2002).

\subsubsection{Yield measurement}

Coffee yield was calculated by sampling three twigs (middle, low and high parts of the bush) selected with equal probability and independently from each other. Five randomly selected trees in each plot were sampled by making a composite sample of $500 \mathrm{grs}$ of berries sampled at the three twigs. The coffee berries were harvested between April and September 2009. Every week, coffee berries were harvested on the selected trees. The berries were cleaned, oven-dried at $60^{\circ} \mathrm{C}$ during $48 \mathrm{~h}$ (after constant weight), and weighed. Coffee yield was determined for each random selected tree, and a spatial mean plot value was calculated using:

$\bar{y}=\frac{1}{n} \sum_{i=1}^{n} y_{i}$

Where $\bar{y}\left(t h^{-1}\right)$ is the average coffee yield measured for the season, from April to September; $\mathrm{n}$ is the number of sample points; $\mathrm{y}_{\mathrm{i}}\left(\mathrm{t} \mathrm{ha} \mathrm{h}^{-1}\right)$ is the yield at sample point $\mathrm{i}$. 


\subsubsection{Nutrient budget}

The concentrations of $\mathrm{N}, \mathrm{P}, \mathrm{K}, \mathrm{Ca}$ and $\mathrm{Mg}$ in the mulch were expressed as $\mathrm{g} \mathrm{kg}^{-1}$ of mulch applied, and converted into $\mathrm{kg} \mathrm{ha}^{-1}$. Additional nutrient rates (nutrient budget) were calculated to supplement deficiencies and balance the nutrient budget for coffee. The additional rates would compensate the losses including losses by soil erosion, deep percolation, and the nutrients removed by the crop.

The nutrient budget of $\mathrm{N}, \mathrm{P}, \mathrm{K}, \mathrm{Ca}$ and $\mathrm{Mg}$ were calculated separately using coffee nutrients requirements of NPK (22-6-12) applied at $200 \mathrm{~kg} \mathrm{ha}^{-1} \mathrm{yr}^{-1}$ (i.e., $44 \mathrm{~N}, 5.2$, and $19.9 \mathrm{~K} \mathrm{~kg} \mathrm{ha}^{-1}$ $\mathrm{yr}^{-1}$ ) and Ca-Mg (60-16) at $1 \mathrm{~kg}$ of lime per tree (i.e., $1072 \mathrm{Ca}$ and $482 \mathrm{Mg} \mathrm{kg} \mathrm{ha}^{-1} \mathrm{yr}^{-1}$ ) (Cordingley, 2009). The balance of N, P, K, Ca and Mg were calculated as the sum of all inputs " $n$ " required minus output of the systems using:

$\sum_{i=1}^{n}[N]_{\text {Required }}=\sum_{i=1}^{n}[N]_{\text {Organic }}+\sum_{i=1}^{n}[N]_{\text {Soil }}+\sum_{i=1}^{n}[N]_{\text {losses }}$

Where,

$$
\begin{array}{ll}
\sum_{i=1}^{n}[N]_{\text {Required }} & \left(\mathrm{kg} \mathrm{ha}^{-1}\right) \text { is the sum of required concentrations " } \mathrm{n} \text { " } \\
\sum_{i=1}^{n}[N]_{\text {Organic }} & \left(\mathrm{kg} \mathrm{ha}^{-1}\right) \text { is the sum of organic inputs from mulch } \\
\sum_{i=1}^{n}[N] & \left(\mathrm{kg} \mathrm{ha}^{-1}\right) \text { is the sum of inputs retained into the soil } \\
\sum_{i=1}^{n}[N]_{\text {losses }} & \left(\mathrm{kg} \mathrm{ha}^{-1}\right) \text { is the sum of " } \mathrm{n} \text { " concentrations lost from the system }
\end{array}
$$

\subsubsection{Data analysis}

All data were subjected to normality and heterogeneity tests using Shapiro-Wilk and Levene tests. Significant differences between soil chemical properties, mulch nutrient concentrations and coffee yield in the treatments were subjected to factorial two-way ANOVA using a General Linear Model. We assessed the effects of the different treatments and their interactions with soil types and site locations on changes in soil nutrient levels and coffee yields. Duncan's multiple range test was applied to compare treatment means and rank them in descending order. Principal Component analysis (PCA) was conducted using 
CANOCO 5 statistical software to assess the effects of interactions between the factors on the soil properties and coffee yield.

\subsection{Results}

\subsubsection{Soil pH and exchangeable soil Al}

The mulch had specific effects on soil acidity and exchangeable soil acidity at each site (Tables 5.2). All soils were acidic with a $\mathrm{pH}\left(\mathrm{H}_{2} \mathrm{O}\right)$ below 5 and exchangeable Al contents reached $0.34 \mathrm{mmol}^{(+)} \mathrm{kg}^{-1}$. The application of Cymbopogon spp. mixed with Panicum spp (T3) resulted in a significantly higher soil $\mathrm{pH}$ value $(\mathrm{P}<0.05)$ and significant lower $\mathrm{Al}$ levels at Kibirizi, where the soil acidity was reduced by $42 \%$. The other mulches had no effect on the soil $\mathrm{pH}$ in this site.

At Karongi, Eucalyptus spp. mixed with Cymbopogon spp. (T4) and mixed residues (T5) resulted in a significantly higher soil $\mathrm{pH}$ and significant lower $\mathrm{Al}$ than the control T6 $(\mathrm{P}<0.05)$ (Table 5.2). Treatment T5 had the same effect on the soils of Ruli and $43 \%$ of soil exchangeable acidity was reduced (Table 5.2).

\subsubsection{Soil nutrients availability}

Mulching improved soil nutrient concentrations as compared to the control (Table 5.3a-c). Significant differences were observed between the treatments $(P<0.001)$, except at Ruli, where the mulch had little effect on soil nutrient availability (Table 5.3c). At Kibirizi, the soil organic C (SOC) content ranged between 15 and $37 \mathrm{~g} \mathrm{~kg}^{-1}$, total $\mathrm{N}$ was below $2.4 \mathrm{~g} \mathrm{~kg}^{-1}$ soil, the concentrations of available $P$ varied between 6 to $15 \mathrm{mg} \mathrm{kg}^{-1}$ soil, and the levels of cations were low. The soils under treatments T5 and T2 had significant high SOC content, total $\mathrm{N}$ and base saturation compared to the control T6 $(\mathrm{P}<0.05)$, while available $\mathrm{P}$ had increased with $\mathrm{T} 1$ by 5.7 times (Table 5.3a). At Karongi, T4 had significantly high SOC content, high total $N$, high available $P$ and significant base saturation $(P<0.05)$. The SOC content ranged between 1.2 and $2.6 \%$, the total $\mathrm{N}$ was below $2.5 \mathrm{~g} \mathrm{~kg}^{-1}$ soil, the concentrations of available $P$ varied between 7 to $14 \mathrm{mg} \mathrm{kg}^{-1}$ soil, and the base saturation varied between 56 and $80 \%$ (Table $5.3 \mathrm{~b}$ ). 
Table 5.2 Effect of treatments on soil acidity and exchangeable soil acidity at Kibirizi, Karongi and Ruli (mean and sd)

\begin{tabular}{|c|c|c|c|c|c|c|c|c|}
\hline Treatment $^{\mathrm{a}}$ & $\mathrm{pH}\left(\mathrm{H}_{2} \mathrm{O}\right)$ & $\begin{array}{c}\mathrm{Al3+} \\
\left(\mathrm{mmol}^{(+)} \mathrm{kg}^{-1}\right)\end{array}$ & $\begin{array}{c}\mathrm{H}+ \\
\left(\mathrm{mmol}^{(+)} \mathrm{kg}^{-1}\right)\end{array}$ & $\begin{array}{l}\text { Al. sat. } \\
\text { (\%) }\end{array}$ & $\mathrm{pH}\left(\mathrm{H}_{2} \mathrm{O}\right)$ & $\begin{array}{c}\mathrm{Al} 3+ \\
\left(\mathrm{mmol}^{(+)} \mathrm{kg}^{-1}\right)\end{array}$ & $\begin{array}{c}\mathrm{H}+ \\
\left(\mathrm{mmol}^{(+)} \mathrm{kg}^{-1}\right)\end{array}$ & $\begin{array}{l}\text { Al. sat. } \\
(\%)\end{array}$ \\
\hline & \multicolumn{4}{|c|}{ Kibirizi } & \multicolumn{3}{|c|}{ Karongi } & \\
\hline $\mathrm{T} 1$ & $4.21 \pm 0.21 \mathrm{~b}^{\mathrm{b}}$ & $0.29 \pm 0.09 a$ & $0.17 \pm 0.02 a$ & $38.7 \pm 13.9 \mathrm{ab}$ & $4.39 \pm 0.15 b$ & $0.16 \pm 0.02 \mathrm{ab}$ & $0.02 \pm 0.01 \mathrm{~b}$ & $25.0 \pm 4.8 \mathrm{~b}$ \\
\hline $\mathrm{T} 2$ & $4.45 \pm 0.38 \mathrm{ab}$ & $0.34 \pm 0.15 a$ & $0.03 \pm 0.01 c$ & $53.5 \pm 16.4 \mathrm{a}$ & $4.59 \pm 0.18 a b$ & $0.12 \pm 0.03 b$ & $0.03 \pm 0.01 b$ & $16.0 \pm 2.9 c$ \\
\hline T3 & $4.87 \pm 0.21 a$ & $0.10 \pm 0.02 b$ & $0.11 \pm 0.02 b$ & $8.9 \pm 3.2 \quad c$ & $4.51 \pm 0.19 a b$ & $0.17 \pm 0.05 \mathrm{ab}$ & $0.04 \pm 0.02 b$ & $22.6 \pm 8.1 \mathrm{bc}$ \\
\hline $\mathrm{T} 4$ & $4.28 \pm 0.36 b$ & $0.26 \pm 0.11 \mathrm{a}$ & $0.10 \pm 0.04 b$ & $33.2 \pm 16.0 \mathrm{~b}$ & $4.86 \pm 0.36 a$ & $0.15 \pm 0.04 a b$ & $0.09 \pm 0.06 a$ & $15.6 \pm 3.2 \mathrm{c}$ \\
\hline T5 & $4.64 \pm 0.57 a b$ & $0.27 \pm 1.88 \mathrm{a}$ & $0.03 \pm 0.02 c$ & $33.0 \pm 18.3 \mathrm{~b}$ & $4.82 \pm 0.46 a$ & $0.14 \pm 0.05 b$ & $0.05 \pm 0.03 b$ & $16.5 \pm 7.0 \mathrm{c}$ \\
\hline T6 & $4.42 \pm 0.12 b$ & $0.31 \pm 0.07 a$ & $0.04 \pm 0.02 c$ & $53.1 \pm 3.5 \quad$ a & $4.30 \pm 0.15 b$ & $0.20 \pm 0.05 a$ & $0.06 \pm 0.04 a b$ & $35.2 \pm 7.4 a$ \\
\hline \multicolumn{9}{|c|}{ Mean of soil types } \\
\hline Inceptisols & $4.62 \pm 0.37$ & $0.18 \pm 0.08$ & $0.08 \pm 0.05$ & $28.9 \pm 16.0$ & $4.73 \pm 0.37$ & $0.15 \pm 0.06$ & $0.05 \pm 0.05$ & $19.8 \pm 9.2$ \\
\hline Ultisols & $4.34 \pm 0.35$ & $0.34 \pm 0.14$ & $0.08 \pm 0.06$ & $44.6 \pm 20.2$ & $4.42 \pm 0.19$ & $0.16 \pm 0.03$ & $0.05 \pm 0.02$ & $23.8 \pm 8.5$ \\
\hline \multicolumn{9}{|c|}{ ANOVA (P-value) } \\
\hline Mulch & $\mathrm{P}<0.05$ & Ns & $P<0.001$ & $P<0.05$ & $\mathrm{P}<0.05$ & $\mathrm{P}<0.05$ & $P<0.05$ & $P<0.001$ \\
\hline Soil & ns & $P<0.05$ & ns & $P<0.05$ & $P<0.05$ & ns & ns & $P<0.001$ \\
\hline Mulch*Soil & $P<0.001$ & $P<0.001$ & ns & $P<0.001$ & ns & ns & $\mathrm{P}<0.05$ & ns \\
\hline Mulch*Soil*Site & $P<0.001$ & $P<0.001$ & $\mathrm{P}<0.001$ & $\mathrm{P}<0.001$ & $P<0.001$ & $P<0.001$ & $P<0.001$ & $P<0.001$ \\
\hline \multicolumn{5}{|c|}{ Ruli } & & & & \\
\hline $\mathrm{T} 1$ & $4.55 \pm 0.23 b^{b}$ & $0.29 \pm 0.12 a$ & $0.20 \pm 0.07 a$ & $38.6 \pm 18.0 a$ & & & & \\
\hline $\mathrm{T} 2$ & $4.48 \pm 0.19 b$ & $0.29 \pm 0.08 a$ & $0.23 \pm 0.07 a$ & $36.6 \pm 9.7 \mathrm{a}$ & & & & \\
\hline T3 & $4.44 \pm 0.12 b$ & $0.33 \pm 0.13 a$ & $0.22 \pm 0.09 a$ & $42.1 \pm 15.6 a$ & & & & \\
\hline $\mathrm{T} 4$ & $4.44 \pm 0.33 b$ & $0.34 \pm 0.18 a$ & $0.20 \pm 0.05 a$ & $39.8 \pm 19.2 a$ & & & & \\
\hline T5 & $4.84 \pm 0.25 a$ & $0.13 \pm 0.07 b$ & $0.17 \pm 0.11 a$ & $17.2 \pm 8.6 b$ & & & & \\
\hline T6 & $4.60 \pm 0.17 b$ & $0.33 \pm 0.12 a$ & $0.20 \pm 0.05 a$ & $39.6 \pm 12.3 a$ & \multirow{2}{*}{\multicolumn{4}{|c|}{$\begin{array}{l}\text { a See Table } 5.1 \text { for the } n \\
\quad P<0.05 ; a>b>c ; n=36 \text {. }\end{array}$}} \\
\hline \multicolumn{5}{|c|}{ Mean of soil types } & & & & \\
\hline Inceptisols & $4.48 \pm 0.32$ & $0.34 \pm 0.14$ & $0.18 \pm 0.08$ & $41.2 \pm 15.1$ & & & & \\
\hline Ultisols & $4.64 \pm 0.13$ & $0.24 \pm 0.11$ & $0.22 \pm 0.05$ & $30.1 \pm 15.1$ & & & & \\
\hline \multicolumn{5}{|c|}{ ANOVA (P-value) } & sta & stically differen & . & 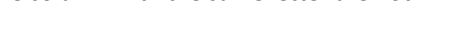 \\
\hline Mulch & $P<0.05$ & ns & ns & $P<0.05$ & & & & \\
\hline Soil & ns & ns & ns & ns & & & & \\
\hline Mulch*Soil & $P<0.001$ & $P<0.05$ & $P<0.05$ & $\mathrm{P}<0.05$ & & & & \\
\hline Mulch*Soil*Site & $P<0.001$ & $P<0.001$ & $P<0.001$ & $\mathrm{P}<0.001$ & & & & \\
\hline
\end{tabular}


Table 5.3a Effects of mulching systems on soil nutrients' availability and coffee yield (t ha-1) at Kibirizi (mean and sd)

\begin{tabular}{|c|c|c|c|c|c|c|c|c|c|c|c|}
\hline Treatment $^{\mathrm{a}}$ & $\begin{array}{c}\text { O.C } \\
\left(\mathrm{g} \mathrm{kg}^{-1}\right)\end{array}$ & $\begin{array}{c}\text { Tot N } \\
\left(\mathrm{g} \mathrm{kg}^{-1}\right)\end{array}$ & $\begin{array}{l}\text { P_Olsen } \\
\left(\mathrm{mg} \mathrm{kg}^{-1}\right)\end{array}$ & $\begin{array}{c}\mathrm{Na}^{+} \\
\left(\mathrm{mg} \mathrm{kg}^{-1}\right)\end{array}$ & $\begin{array}{c}\mathrm{K}^{+} \\
\left(\mathrm{mg} \mathrm{kg}^{-1}\right)\end{array}$ & $\begin{array}{c}\mathrm{Ca}^{2+} \\
\left(\mathrm{mg} \mathrm{kg}^{-1}\right)\end{array}$ & $\begin{array}{c}\mathrm{Mg}^{2+} \\
\left(\mathrm{mg} \mathrm{kg}^{-1}\right)\end{array}$ & $\begin{array}{c}(\mathrm{Ca}+\mathrm{Mg}) / \mathrm{K} \\
\left(\mathrm{mg} \mathrm{kg}^{-1}\right)\end{array}$ & $\begin{array}{c}\text { ECEC }^{c} \\
\left(\mathrm{mg} \mathrm{kg}^{-1}\right)\end{array}$ & $\begin{array}{c}\text { Base sat. } \\
\text { (\%) }\end{array}$ & $\begin{array}{c}\text { Yield } \\
\left(\mathrm{t} \mathrm{ha}^{-1}\right)\end{array}$ \\
\hline $\mathrm{T} 1$ & $26.3 \pm 2.4 \mathrm{~b}^{\mathrm{b}}$ & $1.85 \pm 0.05 b c$ & $14.78 \pm 3.87 a$ & $0.07 \pm 0.04 b c$ & $0.41 \pm 0.24 \mathrm{bc}$ & $0.77 \pm 0.36 c$ & $0.31 \pm 0.20 d$ & $2.73 \pm 0.82 b$ & $7.72 \pm 0.62 b$ & $19.7 \pm 8.3 d$ & $1.09 \pm 0.03 b c$ \\
\hline $\mathrm{T} 2$ & $33.3 \pm 5.9 a$ & $2.03 \pm 0.28 b$ & $5.78 \pm 1.96 b c$ & $0.40 \pm 0.05 a$ & $0.22 \pm 0.08 c$ & $1.31 \pm 0.45 \mathrm{c}$ & $0.47 \pm 0.22 \mathrm{bcd}$ & $8.87 \pm 4.13 a$ & $6.09 \pm 1.07 \mathrm{~cd}$ & $40.7 \pm 14.5 b$ & $1.26 \pm 0.17 a$ \\
\hline T3 & $20.8 \pm 1.7 b$ & $1.50 \pm 0.11 d$ & $6.73 \pm 3.80 b$ & $0.05 \pm 0.01 c$ & $1.28 \pm 0.28 a$ & $2.17 \pm 0.49 \mathrm{~b}$ & $1.10 \pm 0.27 a$ & $2.61 \pm 0.60 \mathrm{~b}$ & $11.28 \pm 1.57 a$ & $40.5 \pm 2.9 b$ & $1.17 \pm 0.02 \mathrm{ab}$ \\
\hline T4 & $23.5 \pm 7.2 b$ & $1.73 \pm 0.24 c$ & $8.32 \pm 4.33 b$ & $0.15 \pm 0.17 b$ & $0.46 \pm 0.20 \mathrm{~b}$ & $1.29 \pm 0.44 b$ & $0.60 \pm 0.20 b c$ & $4.68 \pm 2.09 \mathrm{~b}$ & $7.94 \pm 0.62 b$ & $31.5 \pm 10.6 c$ & $1.01 \pm 0.18 \mathrm{bc}$ \\
\hline T5 & $37.2 \pm 5.2 \mathrm{a}$ & $2.38 \pm 0.21 a$ & $8.60 \pm 1.31 b$ & $0.44 \pm 0.05 a$ & $0.46 \pm 0.04 b$ & $2.90 \pm 0.65 a$ & $0.67 \pm 0.23 \mathrm{~b}$ & $7.67 \pm 1.14 a$ & $7.48 \pm 1.75 b c$ & $62.5 \pm 17.6 a$ & $1.01 \pm 0.14 \mathrm{bc}$ \\
\hline T6 & $15.4 \pm 1.5 c$ & $1.31 \pm 0.08 \mathrm{~d}$ & $2.58 \pm 0.79 c$ & $0.45 \pm 0.03 a$ & $0.21 \pm 0.09 c$ & $1.28 \pm 0.27 c$ & $0.37 \pm 0.04 c d$ & $8.56 \pm 2.08 a$ & $5.88 \pm 1.04 d$ & $39.3 \pm 2.2 b$ & $0.96 \pm 0.17 c$ \\
\hline \multicolumn{12}{|c|}{ Mean of soil types } \\
\hline Inceptisols & $25.9 \pm 9.4$ & $1.75 \pm 0.33$ & $9.04 \pm 4.84$ & $0.27 \pm 0.20$ & $0.53 \pm 0.34$ & $1.67 \pm 0.71$ & $0.70 \pm 0.31$ & $6.08 \pm 3.56$ & $7.18 \pm 2.25$ & $45.9 \pm 17.2$ & $1.10 \pm 0.12$ \\
\hline Ultisols & $26.3 \pm 7.9$ & $1.85 \pm 0.45$ & $6.56 \pm 4.28$ & $0.25 \pm 0.19$ & $0.19 \pm 0.50$ & $1.57 \pm 0.96$ & $0.47 \pm 0.30$ & $5.63 \pm 3.18$ & $8.29 \pm 1.86$ & $32.1 \pm 12.7$ & $1.06 \pm 0.20$ \\
\hline \multicolumn{12}{|c|}{ ANOVA (P-value) } \\
\hline Mulch & $P<0.001$ & $P<0.001$ & $P<0.001$ & $P<0.001$ & $P<0.05$ & $P<0.001$ & $P<0.05$ & $P<0.001$ & $P<0.05$ & $P<0.05$ & $P<0.05$ \\
\hline Soil & ns & ns & $P<0.05$ & ns & ns & ns & $P<0.05$ & ns & ns & $P<0.05$ & ns \\
\hline Mulch*Soil & ns & $P<0.05$ & ns & ns & $P<0.001$ & ns & ns & ns & $P<0.05$ & $P<0.001$ & $P<0.001$ \\
\hline Mulch*Site & $P<0.001$ & $P<0.001$ & $P<0.001$ & $P<0.001$ & $P<0.001$ & $P<0.001$ & $P<0.001$ & ns & $P<0.001$ & $P<0.001$ & $P<0.001$ \\
\hline
\end{tabular}

a : See Table 5.1 for the notes; significant differences ( $P<0.05$ ); ns: not significant at $P<0.05 ; a>b>c ; n=36$

$\mathrm{b}$ : For each parameter, values in the same column with the same letter are not statistically different

c: ECEC= Effective cation exchange capacity

N.B. Coffee nutrients requirements are equivalent to $44 \mathrm{~N}, 5.2 \mathrm{P}, 19.9 \mathrm{~K}, 1072 \mathrm{Ca}$ and $482 \mathrm{Mg} \mathrm{kg} \mathrm{ha}^{-1} \mathrm{yr}^{-1}$ (Cordingley, 2009) 
Table 5.3b Effects of mulching systems on soil nutrients' availability and coffee yield (t ha $\left.{ }^{-1}\right)$ at Karongi, (mean and sd)

\begin{tabular}{|c|c|c|c|c|c|c|c|c|c|c|c|}
\hline Treatment $^{a}$ & $\begin{array}{c}\text { O.C } \\
\left(\mathrm{g} \mathrm{kg}^{-1}\right)\end{array}$ & $\begin{array}{c}\text { Tot N } \\
\left(\mathrm{g} \mathrm{kg}^{-1}\right)\end{array}$ & $\begin{array}{l}\text { P_Olsen } \\
\left(\mathrm{mg} \mathrm{kg}^{-1}\right)\end{array}$ & $\begin{array}{c}\mathrm{Na}^{+} \\
\left(\mathrm{mg} \mathrm{kg}^{-1}\right)\end{array}$ & $\begin{array}{c}\mathrm{K}^{+} \\
\left(\mathrm{mg} \mathrm{kg}^{-1}\right)\end{array}$ & $\begin{array}{c}\mathrm{Ca}^{2+} \\
\left(\mathrm{mg} \mathrm{kg}^{-1}\right)\end{array}$ & $\begin{array}{c}\mathrm{Mg}^{2+} \\
\left(\mathrm{mg} \mathrm{kg}^{-1}\right)\end{array}$ & $\begin{array}{c}(\mathrm{Ca}+\mathrm{Mg}) / \mathrm{K} \\
\left(\mathrm{mg} \mathrm{kg}^{-1}\right)\end{array}$ & $\begin{array}{c}\text { ECEC }^{\mathrm{C}} \\
\left(\mathrm{mg} \mathrm{kg}^{-1}\right)\end{array}$ & $\begin{array}{c}\text { Base sat. } \\
\text { (\%) }\end{array}$ & $\begin{array}{c}\text { Yield } \\
\left(\mathrm{t} \mathrm{ha}^{-1}\right)\end{array}$ \\
\hline T1 & $13.5 \pm 2.1 \mathrm{c}^{\mathrm{b}}$ & $1.63 \pm 0.50 \mathrm{bc}$ & $7.77 \pm 3.46 \mathrm{c}$ & $0.34 \pm 0.20 b c$ & $0.20 \pm 0.04 \mathrm{~b}$ & $3.86 \pm 0.44 b$ & $0.22 \pm 0.07 c$ & $21.8 \pm 8.1 \mathrm{a}$ & $6.46 \pm 0.56 \mathrm{~cd}$ & $71.4 \pm 4.7 a$ & $1.87 \pm 0.02 a$ \\
\hline $\mathrm{T} 2$ & $17.0 \pm 3.7 b c$ & $2.04 \pm 0.23 a b$ & $9.55 \pm 2.38 b c$ & $0.57 \pm 0.08 a$ & $0.26 \pm 0.09 \mathrm{~b}$ & $4.67 \pm 0.60 \mathrm{ab}$ & $0.49 \pm 0.27 b c$ & $22.9 \pm 11.2 a$ & $7.48 \pm 1.13 b c$ & $80.0 \pm 3.1 a$ & $1.50 \pm 0.06 b c$ \\
\hline T3 & $14.5 \pm 3.3 c$ & $2.06 \pm 0.46 a b$ & $8.24 \pm 2.97 b c$ & $0.53 \pm 0.10 \mathrm{ab}$ & $0.23 \pm 0.06 \mathrm{~b}$ & $4.34 \pm 1.04 a b$ & $0.35 \pm 0.22 b c$ & $21.2 \pm 5.2 \mathrm{a}$ & $7.54 \pm 0.89 \mathrm{bc}$ & $71.6 \pm 9.7 a$ & $1.56 \pm 0.17 b$ \\
\hline $\mathrm{T} 4$ & $25.7 \pm 5.6 a$ & $2.47 \pm 0.42 a$ & $13.87 \pm 2.06 a$ & $0.64 \pm 0.22 a$ & $0.42 \pm 0.13 a$ & $5.24 \pm 0.61 a$ & $1.06 \pm 0.61 a$ & $15.9 \pm 3.7 a$ & $9.83 \pm 1.98 a$ & $75.3 \pm 6.6 a$ & $1.43 \pm 0.07 c$ \\
\hline T5 & $21.0 \pm 7.4 a b$ & $2.25 \pm 0.67 a$ & $11.57 \pm 4.17 \mathrm{ab}$ & $0.58 \pm 0.28 a$ & $0.26 \pm 0.05 b$ & $4.99 \pm 0.97 a$ & $0.74 \pm 0.61 a b$ & $21.5 \pm 2.1 \mathrm{a}$ & $8.40 \pm 1.32 \mathrm{ab}$ & $77.8 \pm 10.5 a$ & $1.52 \pm 0.13 b c$ \\
\hline T6 & $12.2 \pm 3.5 \mathrm{c}$ & $1.28 \pm 0.22 c$ & $6.79 \pm 0.93 c$ & $0.19 \pm 0.15 c$ & $0.16 \pm 0.08 \mathrm{~b}$ & $2.70 \pm 0.88 \mathrm{c}$ & $0.22 \pm 0.04 c$ & $22.5 \pm 11.8 a$ & $5.84 \pm 1.45 \mathrm{~d}$ & $55.8 \pm 9.2 b$ & $1.19 \pm 0.06 d$ \\
\hline \multicolumn{12}{|c|}{ Mean of soil types } \\
\hline Inceptisols & $18.4 \pm 7.0$ & $2.08 \pm 0.52$ & $10.47 \pm 4.12$ & $0.55 \pm 0.26$ & $0.29 \pm 0.12$ & $4.40 \pm 1.01$ & $0.70 \pm 0.57$ & $19.2 \pm 6.0$ & $7.94 \pm 1.81$ & $74.1 \pm 12.2$ & $1.46 \pm 0.23$ \\
\hline Ultisols & $16.2 \pm 5.7$ & $1.83 \pm 0.61$ & $8.79 \pm 2.90$ & $0.40 \pm 0.19$ & $0.22 \pm 0.09$ & $4.20 \pm 1.24$ & $0.33 \pm 0.24$ & $22.8 \pm 8.9$ & $7.24 \pm 1.73$ & $69.8 \pm 8.9$ & $1.56 \pm 0.21$ \\
\hline \multicolumn{12}{|c|}{ ANOVA (P-value) } \\
\hline Mulch & $P<0.001$ & $P<0.001$ & $P<0.001$ & $P<0.001$ & $\mathrm{P}<0.05$ & $P<0.05$ & $P<0.05$ & ns & $P<0.05$ & $P<0.05$ & $P<0.05$ \\
\hline Soil & $P<0.05$ & $P<0.05$ & $P<0.05$ & $\mathrm{P}<0.001$ & ns & ns & $P<0.05$ & ns & ns & $P<0.05$ & ns \\
\hline Mulch*Soil & ns & ns & ns & ns & $P<0.05$ & ns & $P<0.05$ & $\mathrm{P}<0.05$ & ns & ns & $P<0.001$ \\
\hline Mulch*Site & $P<0.001$ & $P<0.001$ & $P<0.001$ & $P<0.001$ & $P<0.001$ & $P<0.001$ & $P<0.001$ & ns & $P<0.001$ & $P<0.001$ & $P<0.001$ \\
\hline
\end{tabular}

a : See Table 5.1 for the notes; significant differences ( $P<0.05$ ); ns: not significant at $P<0.05 ; a>b>c ; n=36$

$\mathrm{b}$ : For each parameter, values in the same column with the same letter are not statistically different

c: $E C E C=$ Effective cation exchange capacity

N.B. Coffee nutrients requirements are equivalent to $44 \mathrm{~N}, 5.2 \mathrm{P}, 19.9 \mathrm{~K}, 1072 \mathrm{Ca}$ and $482 \mathrm{Mg} \mathrm{kg} \mathrm{ha}^{-1} \mathrm{yr}^{-1}$ (Cordingley, 2009) 
Table 5.3c Effects of mulching systems on soil nutrients' availability and coffee yield (t ha-1) at Ruli, (mean and sd)

\begin{tabular}{|c|c|c|c|c|c|c|c|c|c|c|c|}
\hline Treatment $^{\mathrm{a}}$ & $\begin{array}{c}\text { O.C } \\
\left(\mathrm{g} \mathrm{kg}^{-1}\right)\end{array}$ & $\begin{array}{l}\text { Tot N } \\
\left(\mathrm{g} \mathrm{kg}^{-1}\right)\end{array}$ & $\begin{array}{l}\text { P_Olsen } \\
\left(\mathrm{mg} \mathrm{kg}^{-1}\right)\end{array}$ & $\begin{array}{c}\mathrm{Na}^{+} \\
\left(\mathrm{mg} \mathrm{kg}^{-1}\right)\end{array}$ & $\begin{array}{c}\mathrm{K}^{+} \\
\left(\mathrm{mg} \mathrm{kg}^{-1}\right)\end{array}$ & $\begin{array}{c}\mathrm{Ca}^{2+} \\
\left(\mathrm{mg} \mathrm{kg}^{-1}\right)\end{array}$ & $\begin{array}{c}\mathrm{Mg}^{2+} \\
\left(\mathrm{mg} \mathrm{kg}^{-1}\right)\end{array}$ & $\begin{array}{c}(\mathrm{Ca}+\mathrm{Mg}) / \mathrm{K} \\
\left(\mathrm{mg} \mathrm{kg}^{-1}\right)\end{array}$ & $\begin{array}{c}\text { ECEC }^{c} \\
\left(\mathrm{mg} \mathrm{kg}^{-1}\right)\end{array}$ & $\begin{array}{c}\text { Base sat. } \\
\text { (\%) }\end{array}$ & $\begin{array}{l}\text { Yield } \\
\left(\mathrm{t} \mathrm{ha}^{-1}\right)\end{array}$ \\
\hline $\mathrm{T} 1$ & $21.0 \pm 6.9 a^{b}$ & $2.74 \pm 0.83 a$ & $9.89 \pm 3.52 a b$ & $0.42 \pm 0.06 b$ & $0.22 \pm 0.09 \mathrm{~b}$ & $1.53 \pm 0.85 a b$ & $0.62 \pm 0.37 b$ & $10.1 \pm 5.0 a$ & $7.74 \pm 1.01 \mathrm{a}$ & $35.12 \pm 13.9 b$ & $1.39 \pm 0.07 a$ \\
\hline $\mathrm{T} 2$ & $21.1 \pm 9.9 a$ & $2.12 \pm 0.97 a$ & $7.49 \pm 4.60 \mathrm{ab}$ & $0.42 \pm 0.07 \mathrm{~b}$ & $0.16 \pm 0.06 \mathrm{~b}$ & $1.63 \pm 0.93 a b$ & $0.60 \pm 0.30 \mathrm{~b}$ & $14.0 \pm 4.3 a$ & $7.97 \pm 0.99 a$ & $34.19 \pm 12.0 \mathrm{~b}$ & $1.28 \pm 0.21 \mathrm{ab}$ \\
\hline T3 & $24.9 \pm 11.8 \mathrm{a}$ & $2.59 \pm 0.89 a$ & $6.01 \pm 4.43 b$ & $0.47 \pm 0.03 b$ & $0.13 \pm 0.06 b$ & $1.29 \pm 0.90 b$ & $0.49 \pm 0.33 b$ & $13.3 \pm 4.9 a$ & $7.84 \pm 1.12 \mathrm{a}$ & $29.6 \pm 13.4 b$ & $1.19 \pm 0.13 b$ \\
\hline T4 & $18.6 \pm 7.3 a$ & $2.72 \pm 1.49 a$ & $9.24 \pm 5.88 \mathrm{ab}$ & $0.44 \pm 0.04 \mathrm{~b}$ & $0.22 \pm 0.08 b$ & $1.75 \pm 1.03 \mathrm{ab}$ & $0.59 \pm 0.31 b$ & $12.6 \pm 10.1 \mathrm{a}$ & $8.38 \pm 0.65 a$ & $36.2 \pm 15.2 b$ & $1.26 \pm 0.14 \mathrm{ab}$ \\
\hline T5 & $14.3 \pm 4.2 \mathrm{a}$ & $1.73 \pm 0.79 a$ & $5.51 \pm 4.37 b$ & $0.42 \pm 0.04 \mathrm{~b}$ & $0.34 \pm 0.15 a$ & $2.48 \pm 0.69 a$ & $1.36 \pm 0.33 a$ & $12.0 \pm 2.3 \mathrm{a}$ & $7.31 \pm 0.65 a$ & $63.2 \pm 16.4 a$ & $1.34 \pm 0.15 \mathrm{ab}$ \\
\hline T6 & $21.3 \pm 11.0 a$ & $1.67 \pm 0.63 a$ & $11.70 \pm 1.10 \mathrm{a}$ & $0.53 \pm 0.02 a$ & $0.22 \pm 0.06 b$ & $1.62 \pm 0.37 a b$ & $0.61 \pm 0.24 b$ & $10.9 \pm 4.7 a$ & $8.34 \pm 0.64 a$ & $35.8 \pm 7.50 \mathrm{~b}$ & $1.39 \pm 0.11 a$ \\
\hline \multicolumn{12}{|c|}{ Mean of soil types } \\
\hline Inceptisols & $24.1 \pm 8.9$ & $2.76 \pm 1.06$ & $8.66 \pm 5.21$ & $0.46 \pm 0.06$ & $0.20 \pm 0.12$ & $1.58 \pm 0.94$ & $0.64 \pm 0.48$ & $11.8 \pm 5.1$ & $7.98 \pm 1.14$ & $36.3 \pm 20.0$ & $1.27 \pm 0.17$ \\
\hline Ultisols & $16.3 \pm 7.2$ & $1.76 \pm 0.67$ & $7.95 \pm 3.81$ & $0.44 \pm 0.06$ & $0.23 \pm 0.08$ & $1.85 \pm 0.76$ & $0.79 \pm 0.34$ & $12.5 \pm 6.0$ & $7.88 \pm 0.56$ & $41.8 \pm 12.6$ & $1.34 \pm 0.13$ \\
\hline \multicolumn{12}{|c|}{ ANOVA (P-value) } \\
\hline Mulch & ns & ns & $P<0.05$ & $P<0.05$ & $P<0.05$ & $P<0.05$ & $P<0.05$ & ns & ns & $P<0.05$ & $P<0.05$ \\
\hline Soil & $P<0.05$ & $P<0.05$ & ns & $P<0.05$ & ns & ns & ns & ns & ns & ns & ns \\
\hline Mulch*Soil & ns & ns & ns & ns & ns & ns & ns & ns & ns & ns & $P<0.05$ \\
\hline Mulch*Site & $P<0.001$ & $P<0.001$ & $P<0.001$ & $P<0.001$ & $P<0.001$ & $P<0.001$ & $P<0.001$ & ns & $P<0.001$ & $P<0.001$ & $P<0.001$ \\
\hline
\end{tabular}

a : See Table 5.1 for the notes; significant differences ( $p<0.05$ ); ns: not significant at $P<0.05 ; a>b>c ; n=36$

b: For each parameter, values in the same column with the same letter are not statistically different

c: ECEC= Effective cation exchange capacity

N.B. Coffee nutrients requirements are equivalent to $44 \mathrm{~N}, 5.2 \mathrm{P}, 19.9 \mathrm{~K}, 1072 \mathrm{Ca}$ and $482 \mathrm{Mg} \mathrm{kg} \mathrm{ha}{ }^{-1} \mathrm{yr}^{-1}$ (Cordingley, 2009) 

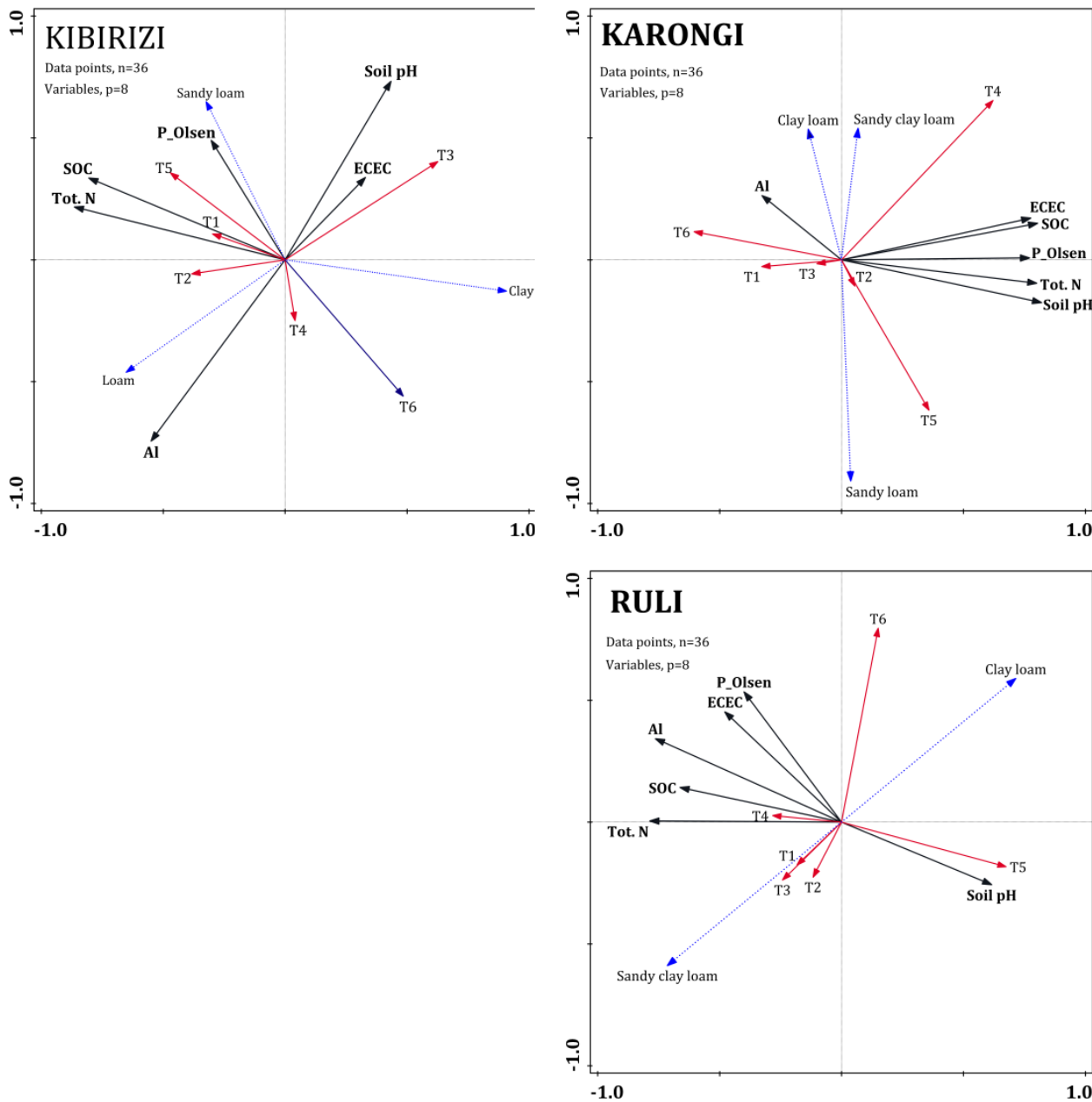

Figure 5.2 Relationship between different mulching systems (T1 to T6 are the different treatments) and soil properties (Al; N; P; $\mathrm{pH}$; SOC: soil organic carbon; ECEC: effective cation exchange capacity) at three study sites (Karongi, Kibirizi and Ruli) located in three different agro-ecological zones

\subsubsection{Soil properties and mulching systems}

Mulching improved soil chemical properties as compared to the control (Fig 5.2). SOC was positively correlated with total $\mathrm{N}$, and available $\mathrm{P}$, after the application of $\mathrm{T} 1, \mathrm{~T} 2$ and $\mathrm{T} 5$ on the sandy loam soils at Kibirizi (Fig 5.2). At Karongi, positive relationships were observed on sandy clay loams after the application of T4, while at Ruli, they were correlated with the application of T1, T3 and T4 (Fig 5.2). On the other hand, the soil properties were negatively correlated with mulch applications on clayey and clayey loam soils (Fig 5.2). 
Available $\mathrm{P}$ was positively correlated with exchangeable Al at Ruli, particularly with T6, T4 and T1 on sandy clay loam soils (Fig 5.2). At the other sites, the ECEC and available P were positively correlated with the increase in soil $\mathrm{pH}$, and negatively affected by the increased in exchangeable Al on sandy clay loams particularly with T3 and T5 at Kibirizi, and with T4 at Karongi (Fig 5.2).

\subsubsection{Coffee yield}

Mulch significantly increased coffee yields on average from 1.2 to $1.9 \mathrm{t} \mathrm{ha}^{-1}(\mathrm{P}<0.05)$. The effects of mulch and the interactions between the mulching systems and soil types were significantly different for each site $(\mathrm{P}<0.001)$ (Table 5.3a-c). At Kibirizi, mulching with $\mathrm{T} 2$ and T3 increased coffee yields up-to $24 \%$ compared to the control T6 (Table 5.3a-c). At Karongi, coffee yields were significantly higher compared to the other sites (Figure 5.3). T1 increased coffee yield by $48 \%$ compared to the highest yield obtained with T2 at Kibirizi (Table 5.3ac). The interactions between mulch and soil properties influenced coffee yield, particularly on sandy clay loam soils compared to finer soil textures at Karongi (Fig 5.4). Similar interactions were observed at Kibirizi on sandy loam soils. On the other hand, at Ruli, coffee yields were highly obtained after the application of T1 on sandy clay loam soils, and were comparable to yields obtained at the control T6 on clay loam soils (Fig 5.4); this coffee yield was $35 \%$ lower compared to the highest yield observed at Karongi (Table 5.3a-c). Thus, coffee yields were positively influenced by the increase in base saturation and soil pH. Yields were negatively affected by high Al saturation and low $\mathrm{K}$ levels, which mainly was found in the finer textured soils (Fig 5.4).

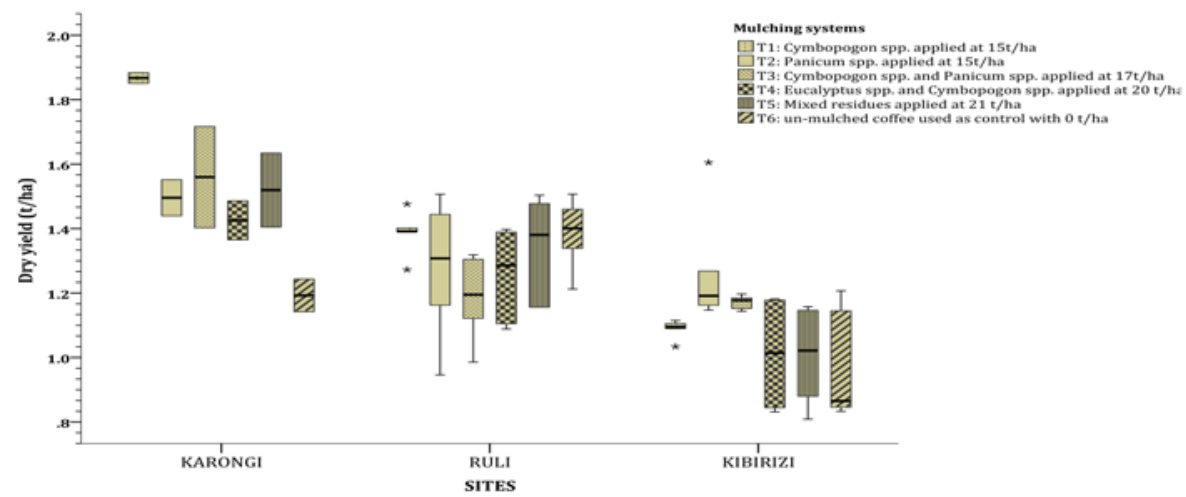

Figure 5.3 Effects of treatments on coffee yield at three agro-ecological zones represented by Karongi, Ruli and Kibirizi study sites 

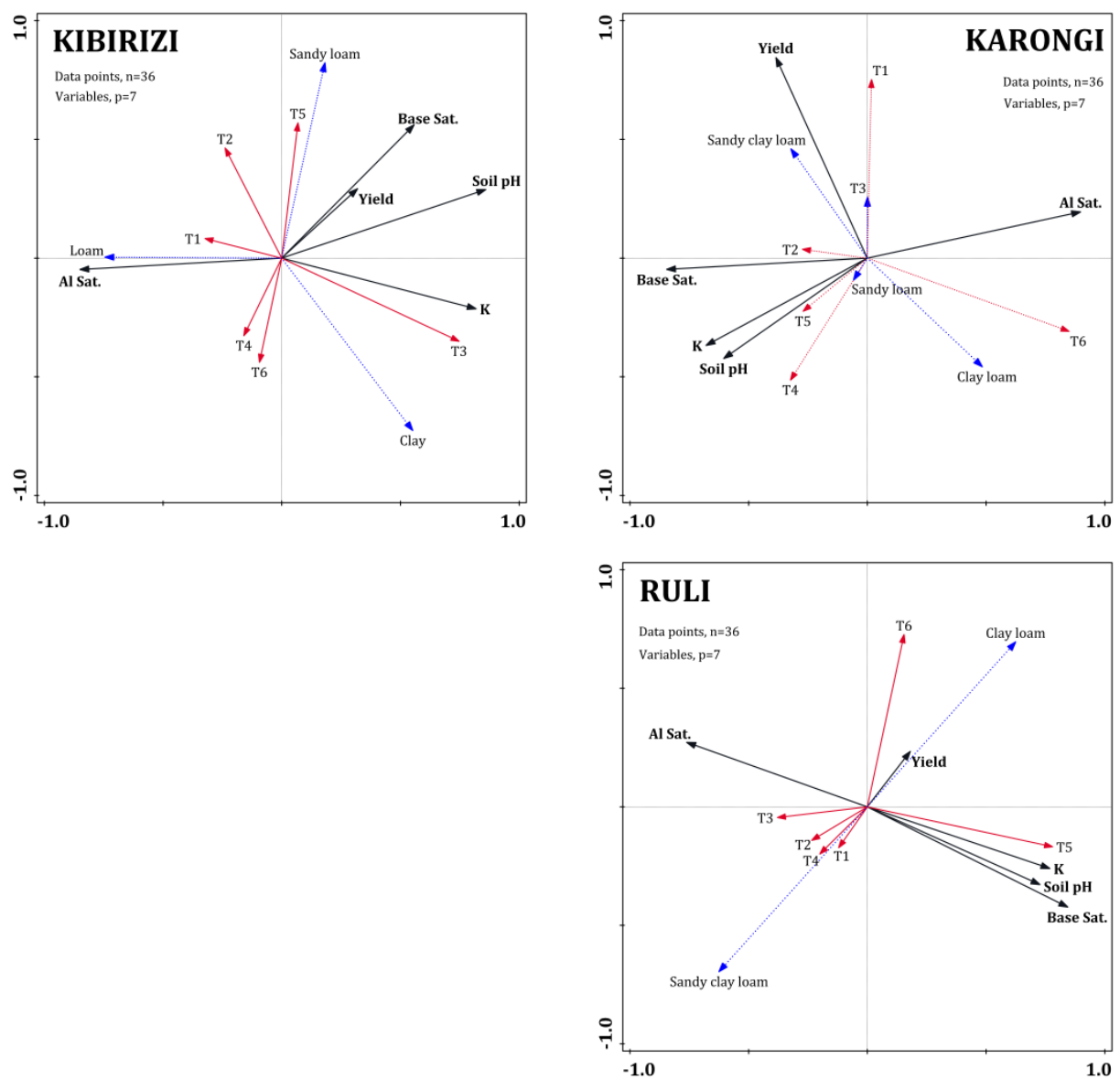

Fig. 5.4. Relationship between different mulching systems ( $T 1$ to $T 6$ are the different treatments), coffee yield and soil properties (Al Sat.: Aluminium saturation; Base sat.: base saturation; $\mathrm{pH}$; $K$ ) at three study sites (Karongi, Kibirizi and Ruli) located in three different agro-ecological zones

\subsubsection{Nutrients in the mulch}

Results of nutrients released from mulches showed contents of $\mathrm{N}, \mathrm{P}, \mathrm{K}, \mathrm{Ca}$ and $\mathrm{Mg}$, depending on type of materials applied at each site (Table 5.4a-c). Significant differences were observed between the treatments $(P<0.001)$. Nutrients released ranged from 21 to 32 $\mathrm{kg} \mathrm{N} \mathrm{ha}^{-1}, 1.3$ to $3.7 \mathrm{~kg} \mathrm{P} \mathrm{ha}^{-1}, 10$ to $11 \mathrm{~kg} \mathrm{~K} \mathrm{ha}^{-1}, 57$ to $75 \mathrm{~kg} \mathrm{Ca} \mathrm{ha}^{-1}$, and 61 to $109 \mathrm{~kg} \mathrm{Mg} \mathrm{ha}$ 1. The highest dose of $32 \mathrm{~kg} \mathrm{~N} \mathrm{ha}^{-1}$ was supplied with mulch collected at Kibirizi under T1, which was 1.2 and 1.5 times higher compared to Karongi and Ruli, respectively. The highest doses of $3.7 \mathrm{~kg} \mathrm{P} \mathrm{ha}^{-1}$ and $75 \mathrm{~kg} \mathrm{Ca} \mathrm{ha}^{-1}$ were supplied with mulch from Karongi under T4. The concentrations of $P$ were 1.3 and 2.9 times higher compared to those of Kibirizi and 
Ruli, respectively, whereas the concentrations of $\mathrm{Ca}$ were 1.3 and 1.1 times higher compared to those of Kibirizi and Ruli, respectively. With mulch collected at Ruli, we observed the highest dose of $109 \mathrm{~kg} \mathrm{Mg} \mathrm{ha}^{-1}$ under T5; these concentrations were 1.1 and 1.8 times higher compared to those of Kibirizi and Karongi, respectively. The $\mathrm{K}$ concentrations were more or less similar at all sites (Table 5.4a-c).

\subsubsection{Fertilizer recommendations}

The mulch alone cannot supply sufficient nutrients to compensate for the removal by the coffee crop and losses. The addition needs for $\mathrm{N}, \mathrm{P}, \mathrm{K}, \mathrm{Ca}$ and $\mathrm{Mg}$ have been estimated. Maximum additions of $27 \mathrm{~kg} \mathrm{~N} \mathrm{ha}^{-1} ; 4.4 \mathrm{~kg} \mathrm{P} \mathrm{ha}^{-1} ; 15 \mathrm{~kg} \mathrm{~K} \mathrm{ha}^{-1} ; 1039 \mathrm{~kg} \mathrm{Ca} \mathrm{ha}^{-1}$; and $466 \mathrm{~kg}$ $\mathrm{Mg} \mathrm{ha}^{-1}$ are needed for coffee farms at Kibirizi, whereas at Karongi, $32 \mathrm{~kg} \mathrm{~N} \mathrm{ha}^{-1} ; 3.6 \mathrm{~kg}^{\mathrm{P}}$ ha${ }^{1} ; 16 \mathrm{~kg} \mathrm{~K} \mathrm{ha}^{-1} ; 1040 \mathrm{~kg} \mathrm{Ca} \mathrm{ha}^{-1}$; and $458 \mathrm{~kg} \mathrm{Mg} \mathrm{ha}^{-1}$ is needed as additional inorganic nutrient inputs, and at Ruli, $34 \mathrm{~kg} \mathrm{~N} \mathrm{ha}^{-1} ; 4.7 \mathrm{~kg} \mathrm{P} \mathrm{ha}^{-1} ; 18 \mathrm{~kg} \mathrm{~K} \mathrm{ha}^{-1} ; 1023 \mathrm{~kg} \mathrm{Ca} \mathrm{ha}^{-1}$; and $448 \mathrm{~kg} \mathrm{Mg}$ $\mathrm{ha}^{-1}$ is needed (Table $5.5 \mathrm{a}-\mathrm{c}$ ).

Table 5.4a Nutrients' content ${ }^{1}$ in the organic mulch ( $\mathrm{kg} \mathrm{ha}^{-1}$ ) applied at Kibirizi, (mean and sd)

\begin{tabular}{|c|c|c|c|c|c|}
\hline Treatment ${ }^{a}$ & $\begin{array}{c}\mathrm{N} \\
\left(\mathrm{kg} \mathrm{ha}^{-1}\right)\end{array}$ & $\begin{array}{c}\mathrm{P} \\
\left(\mathrm{kg} \mathrm{ha}^{-1}\right)\end{array}$ & $\begin{array}{c}\mathrm{K} \\
\left(\mathrm{kg} \mathrm{ha}^{-1}\right)\end{array}$ & $\begin{array}{c}\mathrm{Ca}^{2+} \\
\left(\mathrm{kg} \mathrm{ha}^{-1}\right)\end{array}$ & $\begin{array}{c}\mathrm{Mg}^{2+} \\
\left(\mathrm{kg} \mathrm{ha}^{-1}\right)\end{array}$ \\
\hline $\mathrm{T} 1$ & $16.96 \pm 0.97 c^{b}$ & $1.44 \pm 0.05 c$ & $10.95 \pm 3.36 a$ & $32.9 \pm 1.2 \mathrm{e}$ & $16.1 \pm 1.0 \mathrm{~d}$ \\
\hline $\mathrm{T} 2$ & $22.87 \pm 2.46 b$ & $1.23 \pm 0.10 \mathrm{~d}$ & $11.00 \pm 1.26 a$ & $35.3 \pm 1.1 \mathrm{~d}$ & $42.6 \pm 20.9 c$ \\
\hline T3 & $32.46 \pm 3.99 a$ & $2.28 \pm 0.09 b$ & $8.14 \pm 0.85 b$ & $47.1 \pm 1.0 \mathrm{c}$ & $64.9 \pm 27.0 \mathrm{~b}$ \\
\hline T4 & $31.73 \pm 3.22 \mathrm{a}$ & $0.84 \pm 0.05 e$ & $5.40 \pm 0.76 d$ & $54.4 \pm 3.0 \mathrm{~b}$ & $71.3 \pm 1.8 \mathrm{~b}$ \\
\hline T5 & $25.03 \pm 1.56 b$ & $2.83 \pm 0.17 a$ & $6.72 \pm 0.32 c$ & $57.4 \pm 0.9 a$ & $100.1 \pm 6.2 a$ \\
\hline \multirow[t]{2}{*}{ T6 } & - & - & - & - & - \\
\hline & \multicolumn{3}{|c|}{ Mean of soil types } & & \\
\hline Inceptisols & $25.5 \pm 6.7$ & $1.71 \pm 0.73$ & $9.25 \pm 3.25$ & $45.1 \pm 9.9$ & $63.6 \pm 29.1$ \\
\hline \multirow[t]{2}{*}{ Ultisols } & $26.2 \pm 6.3$ & $1.74 \pm 0.79$ & $7.63 \pm 1.97$ & $45.8 \pm 10.7$ & $54.4 \pm 35.4$ \\
\hline & \multicolumn{3}{|c|}{ ANOVA (P-value) } & & \\
\hline Mulch & $P<0.001$ & $P<0.001$ & $P<0.05$ & $P<0.001$ & $\mathrm{P}<0.05$ \\
\hline Soil & ns & ns & ns & ns & ns \\
\hline Mulch*Soil & ns & ns & $P<0.001$ & $P<0.001$ & $P<0.001$ \\
\hline Mulch*Soil*Site & $P<0.001$ & $P<0.001$ & $P<0.001$ & $P<0.001$ & $P<0.001$ \\
\hline \multirow{2}{*}{\multicolumn{6}{|c|}{$\begin{array}{l}\text { 1. Calculated based on the concentrations of } \mathrm{N}, \mathrm{P}, \mathrm{K}, \mathrm{Ca} \text { and } \mathrm{Mg}\left(\mathrm{g} \mathrm{kg}^{-1}\right) \text { of mulch applied (T1: } 15 \mathrm{t} \mathrm{ha}^{-1} ; \mathrm{T} 2: 15 \mathrm{t} \mathrm{ha}^{-1} ; \mathrm{T} 3 \\
\left.17 \mathrm{t} \mathrm{ha}^{-1} ; \mathrm{T} 4: 20 \mathrm{t} \mathrm{ha}^{-1} \text { and T5: } 21 \mathrm{t} \mathrm{ha}^{-1}\right)\end{array}$}} \\
\hline & & & & & \\
\hline \multicolumn{6}{|c|}{ b: For each parameter, values in the same column with the same letter are not statistically different } \\
\hline
\end{tabular}


Table 5.4b Nutrients' content ${ }^{1}$ in the organic mulch $\left(\mathrm{kg} \mathrm{ha}^{-1}\right)$ applied at Karongi (mean and sd)

\begin{tabular}{|c|c|c|c|c|c|}
\hline Treatment $^{\mathrm{a}}$ & $\begin{array}{c}\mathrm{N} \\
\left(\mathrm{kg} \mathrm{ha}^{-1}\right)\end{array}$ & $\begin{array}{c}\mathrm{P} \\
\left(\mathrm{kg} \mathrm{ha}^{-1}\right)\end{array}$ & $\begin{array}{c}\mathrm{K} \\
\left(\mathrm{kg} \mathrm{ha}^{-1}\right)\end{array}$ & $\begin{array}{c}\mathrm{Ca}^{2+} \\
\left(\mathrm{kg} \mathrm{ha}^{-1}\right)\end{array}$ & $\begin{array}{c}\mathrm{Mg}^{2+} \\
\left(\mathrm{kg} \mathrm{ha}^{-1}\right)\end{array}$ \\
\hline T1 & $11.8 \pm 1.2 \mathrm{~d}^{\mathrm{b}}$ & $1.64 \pm 0.36 c$ & $3.54 \pm 1.12 \mathrm{c}$ & $31.3 \pm 1.5 \mathrm{~d}$ & $24.5 \pm 2.5 d$ \\
\hline $\mathrm{T} 2$ & $14.3 \pm 2.2 b$ & $2.01 \pm 0.13 c$ & $5.21 \pm 1.50 \mathrm{bc}$ & $41.8 \pm 1.5 c$ & $25.4 \pm 1.4 d$ \\
\hline T3 & $13.4 \pm 2.3 \mathrm{~cd}$ & $3.21 \pm 0.35 b$ & $6.36 \pm 1.88 b$ & $39.7 \pm 2.8 c$ & $50.2 \pm 1.5 \mathrm{c}$ \\
\hline $\mathrm{T} 4$ & $27.2 \pm 1.8 \mathrm{a}$ & $3.73 \pm 0.37 a$ & $8.90 \pm 1.88 a$ & $75.1 \pm 16.0 \mathrm{a}$ & $52.8 \pm 5.0 \mathrm{~b}$ \\
\hline T5 & $26.7 \pm 1.6 \mathrm{~b}$ & $3.03 \pm 0.89 b$ & $9.45 \pm 2.04 a$ & $66.6 \pm 3.9 b$ & $60.8 \pm 2.6 a$ \\
\hline \multirow[t]{2}{*}{ T6 } & - & - & - & - & - \\
\hline & \multicolumn{3}{|c|}{ Mean of soil types } & & \\
\hline Inceptisols & $18.7 \pm 5.9$ & $2.59 \pm 0.66$ & $7.44 \pm 2.32$ & $47.8 \pm 14.6$ & $43.7 \pm 15.3$ \\
\hline \multirow[t]{2}{*}{ Ultisols } & $17.4 \pm 7.2$ & $2.86 \pm 1.12$ & $5.94 \pm 3.04$ & $53.9 \pm 21.9$ & $41.7 \pm 16.0$ \\
\hline & \multicolumn{3}{|c|}{ ANOVA (P-value) } & & \\
\hline Mulch & $P<0.001$ & $P<0.05$ & $P<0.001$ & $P<0.05$ & $P<0.001$ \\
\hline Soil & ns & ns & $P<0.05$ & ns & ns \\
\hline Mulch*Soil & ns & $P<0.001$ & ns & $P<0.001$ & $P<0.001$ \\
\hline Mulch*Soil*Site & $\mathrm{P}<0.001$ & $P<0.001$ & $P<0.001$ & $P<0.001$ & $P<0.001$ \\
\hline
\end{tabular}

1: Calculated based on the concentrations of $\mathrm{N}, \mathrm{P}, \mathrm{K}, \mathrm{Ca}$ and $\mathrm{Mg}\left(\mathrm{g} \mathrm{kg}^{-1}\right)$ of mulch applied (T1: $15 \mathrm{t} \mathrm{ha}^{-1}$; T2: $15 \mathrm{t} \mathrm{ha}{ }^{-1}$; T3: $17 \mathrm{t} \mathrm{ha}^{-1}$; T4: $20 \mathrm{t} \mathrm{ha}^{-1}$ and T5: $21 \mathrm{t} \mathrm{ha}^{-1}$ )

a: See Table 5.1 for the notes; T6= Control (not mulched); Significant differences $(p<0.05)$ : $a>b>c>d>e ; n=30$

b: For each parameter, values in the same column with the same letter are not statistically different

Table 5.4c Nutrients' content ${ }^{1}$ in the organic mulch ( $\left.\mathrm{kg} \mathrm{ha}^{-1}\right)$ applied at Ruli (mean and sd)

\begin{tabular}{|c|c|c|c|c|c|}
\hline Treatment $^{a}$ & $\begin{array}{c}\mathrm{N} \\
\left(\mathrm{kg} \mathrm{ha}^{-1}\right)\end{array}$ & $\begin{array}{c}\mathrm{P} \\
\left(\mathrm{kg} \mathrm{ha}^{-1}\right)\end{array}$ & $\begin{array}{c}\mathrm{K} \\
\left(\mathrm{kg} \mathrm{ha}^{-1}\right)\end{array}$ & $\begin{array}{c}\mathrm{Ca}^{2+} \\
\left(\mathrm{kg} \mathrm{ha}^{-1}\right)\end{array}$ & $\begin{array}{c}\mathrm{Mg}^{2+} \\
\left(\mathrm{kg} \mathrm{ha}^{-1}\right)\end{array}$ \\
\hline T1 & $10.3 \pm 0.9 d^{b}$ & $0.58 \pm 0.08 \mathrm{e}$ & $2.06 \pm 0.12 c$ & $49.2 \pm 4.2 c$ & $36.2 \pm 5.1 d$ \\
\hline $\mathrm{T} 2$ & $12.8 \pm 1.6 \mathrm{c}$ & $0.81 \pm 0.16 c$ & $2.67 \pm 0.16 c$ & $51.1 \pm 5.1 c$ & $34.7 \pm 4.2 d$ \\
\hline T3 & $12.5 \pm 1.9 \mathrm{c}$ & $0.65 \pm 0.09 d$ & $2.46 \pm 0.74 c$ & $62.4 \pm 7.7 b$ & $55.1 \pm 9.3 c$ \\
\hline T4 & $20.7 \pm 3.1 \mathrm{a}$ & $1.20 \pm 0.14 b$ & $8.16 \pm 3.72 b$ & $68.1 \pm 1.4 a$ & $85.8 \pm 12.3 b$ \\
\hline T5 & $17.7 \pm 2.1 \mathrm{~b}$ & $1.29 \pm 0.13 a$ & $9.70 \pm 2.55 a$ & $62.3 \pm 9.8 b$ & $108.9 \pm 9.2 a$ \\
\hline \multirow[t]{2}{*}{ T6 } & - & - & - & - & - \\
\hline & \multicolumn{3}{|c|}{ Mean of soil types } & & \\
\hline Inceptisols & $14.1 \pm 3.3$ & $0.80 \pm 0.29$ & $4.05 \pm 2.05$ & $63.5 \pm 8.17$ & $68.0 \pm 27.7$ \\
\hline \multirow[t]{2}{*}{ Ultisols } & $15.5 \pm 5.2$ & $1.01 \pm 0.31$ & $5.97 \pm 4.88$ & $53.8 \pm 8.1$ & $60.3 \pm 33.6$ \\
\hline & \multicolumn{3}{|c|}{ ANOVA (P-value) } & & \\
\hline Mulch & $P<0.05$ & $P<0.001$ & $P<0.05$ & $P<0.05$ & $P<0.001$ \\
\hline Soil & ns & $P<0.001$ & ns & $P<0.05$ & ns \\
\hline Mulch* Soil & $P<0.001$ & $P<0.05$ & $P<0.001$ & $P<0.001$ & $P<0.001$ \\
\hline Mulch*Soil*Site & $P<0.001$ & $P<0.001$ & $P<0.001$ & $P<0.001$ & $P<0.001$ \\
\hline
\end{tabular}

1: Calculated based on the concentrations of $\mathrm{N}, \mathrm{P}, \mathrm{K}, \mathrm{Ca}$ and $\mathrm{Mg}\left(\mathrm{g} \mathrm{kg}^{-1}\right)$ of mulch applied (T1: $15 \mathrm{t} \mathrm{ha}^{-1} ; \mathrm{T2}$ : $15 \mathrm{t} \mathrm{ha}{ }^{-1} ; \mathrm{T}^{2}$ : $17 \mathrm{t} \mathrm{ha}^{-1}$; T4: $20 \mathrm{t} \mathrm{ha}^{-1}$ and T5: $21 \mathrm{t} \mathrm{ha}^{-1}$ )

a: See Table 5.1 for the notes; T6= Control (not mulched); Significant differences $(p<0.05)$ : $a>b>c>d>e ; n=30$

b: For each parameter, values in the same column with the same letter are not statistically different 
Table 5.5a Inorganic fertilizer recommendations ( $\mathrm{N}-\mathrm{P}-\mathrm{K}-\mathrm{Ca}-\mathrm{Mg}$ ) at Kibirizi (mean and sd)

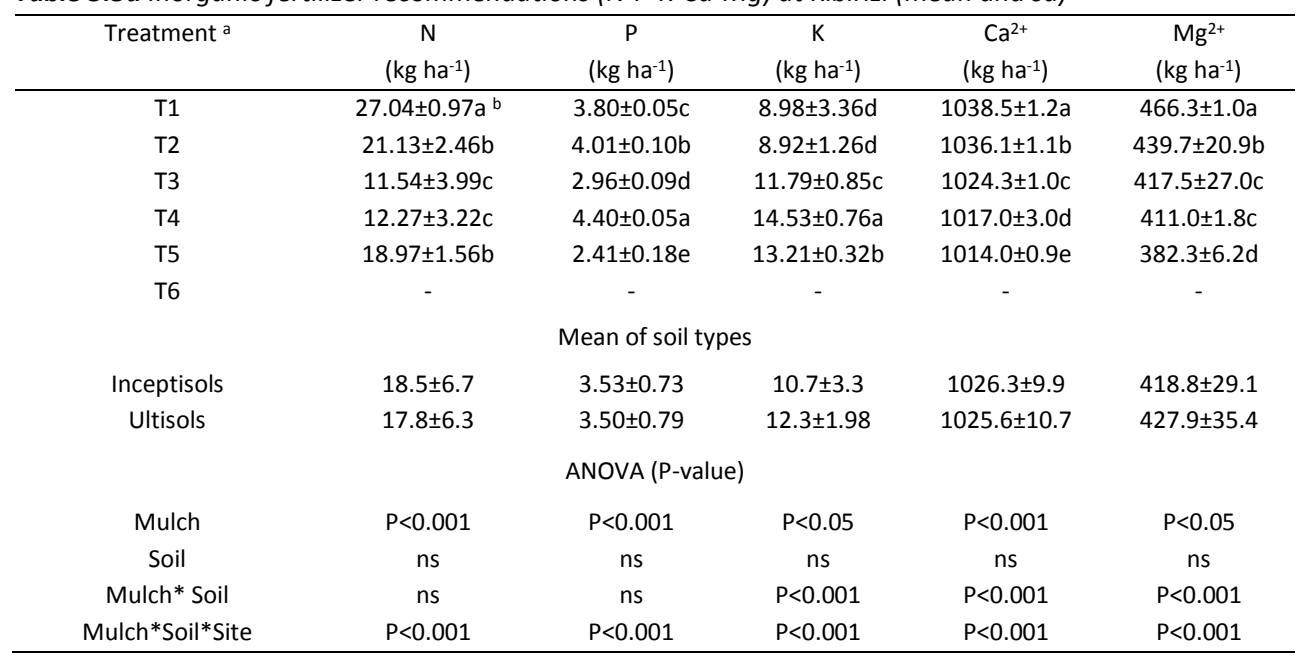

a: See Table 5.1 for the notes; T6= Control (not mulched); Significant differences $(p<0.05)$ : $a>b>c>d>e ; n=30$

b: For each parameter, values in the same column with the same letter are not statistically different

Table 5.5b Inorganic fertilizer recommendations (N-P-K-Ca-Mg) at Karongi (mean and sd)

\begin{tabular}{|c|c|c|c|c|c|}
\hline Treatment $^{\mathrm{a}}$ & $\begin{array}{c}\mathrm{N} \\
\left(\mathrm{kg} \mathrm{ha}^{-1}\right)\end{array}$ & $\begin{array}{c}\mathrm{P} \\
\left(\mathrm{kg} \mathrm{ha}^{-1}\right)\end{array}$ & $\begin{array}{c}\mathrm{K} \\
\left(\mathrm{kg} \mathrm{ha}^{-1}\right)\end{array}$ & $\begin{array}{c}\mathrm{Ca}^{2+} \\
\left(\mathrm{kg} \mathrm{ha}^{-1}\right)\end{array}$ & $\begin{array}{c}\mathrm{Mg}^{2+} \\
\left(\mathrm{kg} \mathrm{ha}^{-1}\right)\end{array}$ \\
\hline T1 & $32.3 \pm 1.2 \mathrm{a}^{\mathrm{b}}$ & $3.60 \pm 0.36 a$ & $16.4 \pm 1.1 a$ & $1040.2 \pm 1.5 a$ & $457.9 \pm 2.5 a$ \\
\hline $\mathrm{T} 2$ & $29.8 \pm 2.2 b$ & $3.23 \pm 0.13 a$ & $14.7 \pm 1.5 a b$ & $1029.7 \pm 1.5 b$ & $457.0 \pm 1.4 a$ \\
\hline T3 & $30.6 \pm 2.3 a b$ & $2.03 \pm 0.35 b$ & $13.6 \pm 1.9 \mathrm{~b}$ & $1031.7 \pm 2.8 b$ & $432.2 \pm 1.5 b$ \\
\hline T4 & $16.8 \pm 1.8 \mathrm{~d}$ & $1.51 \pm 0.37 \mathrm{c}$ & $11.0 \pm 1.9 \mathrm{c}$ & $996.4 \pm 16.0 d$ & $429.5 \pm 5.0 c$ \\
\hline T5 & $20.3 \pm 1.6 c$ & $2.21 \pm 0.89 \mathrm{~b}$ & $10.5 \pm 2.0 \mathrm{c}$ & $1004.8 \pm 3.9 c$ & $421.6 \pm 2.6 d$ \\
\hline T6 & - & - & - & - & - \\
\hline \multicolumn{6}{|c|}{ Mean of soil types } \\
\hline Inceptisols & $25.3 \pm 5.9$ & $2.65 \pm 0.66$ & $12.5 \pm 2.3$ & $1023.6 \pm 14.6$ & $438.7 \pm 15.3$ \\
\hline Ultisols & $26.6 \pm 7.2$ & $2.38 \pm 1.12$ & $14.0 \pm 3.0$ & $1017.5 \pm 21.9$ & $440.7 \pm 16.0$ \\
\hline \multicolumn{6}{|c|}{ ANOVA (P-value) } \\
\hline Mulch & $P<0.001$ & $P<0.05$ & $P<0.001$ & $P<0.05$ & $P<0.001$ \\
\hline Soil & ns & ns & $P<0.05$ & ns & ns \\
\hline Mulch*Soil & ns & $P<0.001$ & ns & $P<0.001$ & $P<0.001$ \\
\hline Mulch*Soil*Site & $P<0.001$ & $P<0.001$ & $P<0.001$ & $P<0.001$ & $P<0.001$ \\
\hline
\end{tabular}

a: See Table 5.1 for the notes; T6= Control (not mulched); Significant differences $(p<0.05)$ : $a>b>c>d>e ; n=30$

b: For each parameter, values in the same column with the same letter are not statistically different 
Table 5.5c Inorganic fertilizer recommendations ( $N-P-K-C a-M g)$ at Ruli (mean and sd)

\begin{tabular}{|c|c|c|c|c|c|}
\hline Treatment ${ }^{a}$ & $\begin{array}{c}\mathrm{N} \\
\left(\mathrm{kg} \mathrm{ha}^{-1}\right)\end{array}$ & $\begin{array}{c}\mathrm{P} \\
\left(\mathrm{kg} \mathrm{ha}^{-1}\right)\end{array}$ & $\begin{array}{c}\mathrm{K} \\
\left(\mathrm{kg} \mathrm{ha}^{-1}\right)\end{array}$ & $\begin{array}{c}\mathrm{Ca}^{2+} \\
\left(\mathrm{kg} \mathrm{ha}^{-1}\right)\end{array}$ & $\begin{array}{c}\mathrm{Mg}^{2+} \\
\left(\mathrm{kg} \mathrm{ha}^{-1}\right)\end{array}$ \\
\hline T1 & $33.7 \pm 0.9 a^{b}$ & $4.66 \pm 0.08 a$ & $17.9 \pm 0.1 \mathrm{a}$ & $1022.2 \pm 4.2 \mathrm{a}$ & $446.2 \pm 5.1 \mathrm{a}$ \\
\hline $\mathrm{T} 2$ & $31.2 \pm 1.5 b$ & $4.43 \pm 0.16 \mathrm{c}$ & $17.3 \pm 0.2 a$ & $1020.3 \pm 5.1 a$ & $447.7 \pm 4.2 \mathrm{a}$ \\
\hline T3 & $31.5 \pm 1.9 \mathrm{~b}$ & $4.59 \pm 0.08 b$ & $17.5 \pm 0.7 a$ & $1009.0 \pm 7.7 \mathrm{~b}$ & $427.3 \pm 9.3 b$ \\
\hline T4 & $23.3 \pm 3.1 d$ & $4.04 \pm 0.14 d$ & $11.8 \pm 3.7 b$ & $1003.4 \pm 1.4 \mathrm{c}$ & $396.6 \pm 12.2 c$ \\
\hline T5 & $26.3 \pm 2.1 \mathrm{c}$ & $3.95 \pm 0.12 \mathrm{e}$ & $10.2 \pm 2.6 c$ & $1009.1 \pm 9.8 b$ & $373.5 \pm 9.2 d$ \\
\hline \multirow[t]{2}{*}{ T6 } & - & - & - & - & - \\
\hline & \multicolumn{4}{|c|}{ Mean of soil types } & \\
\hline Inceptisols & $29.9 \pm 3.3$ & $4.44 \pm 0.29$ & $15.8 \pm 2.1$ & $1007.9 \pm 8.2$ & $414.4 \pm 27.7$ \\
\hline \multirow[t]{2}{*}{ Ultisols } & $28.5 \pm 5.2$ & $4.23 \pm 0.31$ & $14.0 \pm 4.9$ & $1017.7 \pm 8.1$ & $422.1 \pm 33.6$ \\
\hline & \multicolumn{4}{|c|}{ ANOVA (P-value) } & \\
\hline Mulch & $P<0.05$ & $P<0.001$ & $P<0.05$ & $P<0.05$ & $P<0.001$ \\
\hline Soil & ns & $P<0.001$ & ns & $\mathrm{P}<0.05$ & ns \\
\hline Mulch* Soil & $P<0.001$ & $P<0.05$ & $P<0.001$ & $P<0.001$ & $P<0.001$ \\
\hline Mulch*Soil*Site & $P<0.001$ & $P<0.001$ & $P<0.001$ & $P<0.001$ & $P<0.001$ \\
\hline
\end{tabular}

a: See Table 5.1 for the notes; T6= Control (not mulched); Significant differences $(p<0.05)$ : $a>b>c>d>e ; n=30$

b: For each parameter, values in the same column with the same letter are not statistically different

\subsection{Discussion}

\subsubsection{Effect of mulching on exchangeable acidity and nutrient immobilization}

The Al toxicity and exchangeable acidity were higher at Ruli and Kibirizi compared to Karongi site. This may indicate a natural low fertility status of the soils in these two sites, which could be related to poor land management and origin parent material (i.e. schist, shale, and granites) (Verdoodt and Van Ranst, 2003). Generally in Rwanda, most soils under coffee have a low pH (<5.0) with high soil Al levels (>30\%) (Cordingley, 2009). In addition, Ruli and Kibirizi are characterized by humid highlands of above $2,000 \mathrm{~m}$ asl with annual rainfall of about 2,000 $\mathrm{mm}$. These conditions might have accelerated soil acidification under treatments T1 (Cymbopogon spp.) and T2 (Panicum spp.), following the chemical composition of the mulches, their rates of decomposition and mineralization (Abbasi et al., 2015; Khalil et al., 2005; Oliveira et al., 2014; Palm et al., 2001). Organic materials rich in polyphenols and lignin decompose more slowly, particularly under humid conditions (Abbasi et al., 2015; Khalil et al., 2005; Palm and Sanchez, 1990; Zech et al., 1997); hence, this likely contributed to nutrient immobilization (Bekunda et al., 2010; Fageria and Nascente, 2014).

The increase in soil $\mathrm{pH}$ at Ruli and Kibirizi sites was observed under treatments T3 (Cymbopogon spp. mixed with Panicum spp. applied at $17 \mathrm{t} \mathrm{ha}^{-1}$ ), T4 (Eucalyptus spp. mixed 
with Cymbopogon spp. applied at $20 \mathrm{t} \mathrm{ha}^{-1}$ ), and T5 (mixed residues i.e. sorghum thatch, maize and beans residues, banana leaves, Eucalyptus leaves and branches, Panicum spp., and sugar cane applied at $21 \mathrm{t} \mathrm{ha}^{-1}$ ). The increase in soil $\mathrm{pH}$ might be due to the decomposition of these mulches that tend to improve soil exchangeable bases while reducing exchangeable acidity (Awopegba et al., 2017). Treatment T5 was dominantly composed of leaves of banana ("Musacea") and Eucalyptus ("Myrtacea") that contain low concentrations of polyphenols and lignin (Palm et al., 2001). On the other hand, T4 and T5 applied at 20 and $21 \mathrm{t} \mathrm{ha}^{-1}$, respectively, have significant effects on the concentrations of the nutrients. Thus, the amount of nutrients released during mulch decomposition was also regulated by the type and amount of mulch biomass applied, as it was also reported by Lalljee (2013), Adekiya et al. (2017), Herencia and Maqueda (2016) and Awopegba et al. (2017).

\subsubsection{Effect of mulching on $\mathrm{C}$ and $\mathrm{N}$ mineralization and availability}

Our results indicated that the increase in exchangeable acidity in cold and humid areas like Kibirizi and Ruli, resulted in slow decomposition of the mulch, particularly T1 and T2 as they may be high in polyphenols and lignin, which slow down decomposition (Abbasi et al., 2015; Oliveira et al., 2014; Zech et al., 1997). Losses of dissolved organic C and $\mathrm{N}$ have been reported in acid soils in humid zones, whereas mobilized organic matter stock increased (Oliveira et al., 2014; Zech et al., 1997). This was found in the soils of Kibirizi and Ruli, where high rainfall and low $\mathrm{pH}$ may have contributed to the $\mathrm{C}$ and $\mathrm{N}$ immobilization.

The greater SOC content and total $\mathrm{N}$ in the treatments $\mathrm{T} 4$ and $\mathrm{T} 5$, particularly at Kibirizi and Karongi, indicated the potential of these mulches in $\mathrm{C}$ and $\mathrm{N}$ availability following the amounts of mulch biomass added to the soil (Adekiya et al., 2017; Agbede et al., 2014; Xavier et al., 2013). In favorable environmental conditions like at Karongi, the repeated drywet cycles may have enhanced faster microbial degradation of the mulch, resulting in increased $\mathrm{C}$ and $\mathrm{N}$ stocks and improved soil quality through nutrient recycling (Agbede et al., 2014; Khalil et al., 2005; Miura et al., 2013; Murungu et al., 2011; Xavier et al., 2013). Hence, this practice should be promoted to increase organic matter and biological $\mathrm{N}$ fixation to the soil.

Decomposition and mineralization of $\mathrm{C}$ and $\mathrm{N}$ was also affected by the soil texture. Our results showed that the released nutrients were retained in mulched coffee plots that have clayey soils (T4 and T5) at Karongi. The quick mineralization of $\mathrm{C}$ and $\mathrm{N}$ in clayey soils is common as they are associated at the clay specific areas at maximum retention capacity (Hassink, 1997, 1992). The effects are larger for $N$ than for $C$ because the largest specific 
surface of the clay minerals associates with $\mathrm{N}$. This results in protection of the soil organic matter (mainly C) from decomposition (Zech et al., 1997). The increase in $\mathrm{N}$ mineralization is probably explained by the low $\mathrm{C}: \mathrm{N}$ ratios of the mulch. Mulches with a high $\mathrm{C} / \mathrm{N}$ ratio have resulted in high $\mathrm{C}$ and $\mathrm{N}$ contents readily available to soils. Under favorable environmental conditions, land management technologies like mulching can sustain organic carbon and nitrogen stocks in the soil (Agbede et al., 2014; Khalil et al., 2005; Liu et al., 2017). The C and $\mathrm{N}$ availability will depend on the amount of $\mathrm{C}$ and $\mathrm{N}$ mineralized during decomposition and mineralization of the added mulches (Abbasi et al., 2015; Agbede et al., 2014; Murungu et al., 2011). Our results indicated that the amounts of $C$ and $N$ were regulated by the environmental conditional. Similar results were also reported by Khalil et al. (2005) and Abbasi et al. (2015).

\subsubsection{Effect of mulching on fixation and availability of Phosphorus}

The concentration of $\mathrm{P}$ was low in all the soils, and most soils in Rwanda are P deficient with excessive acidity and high Al (Mbonigaba et al., 2009; Mukuralinda, 2007). Phosphorus is immobilised or complexed by $\mathrm{Al}^{3+}$ and $\mathrm{Fe}^{3+}$ (Brady and Weil, 2002; Mbonigaba, 2007). The effect of mulching on increased $\mathrm{P}$ concentrations was observed at Karongi, where T4 (mixed Eucalyptus spp. and Cymbopogon spp.) and T5 (mixed residues) were applied. This demonstrated that T4 and T5 mulches were rich in P content and was released into the soil after decomposition and mineralization of the mulches. The amount of $\mathrm{P}$ content released depended on the types and amount of the added mulches. Similar research findings were also reported by Agbede et al. (2014) and Adekiya et al. (2017).

Our results revealed also that $\mathrm{P}$ was much retained and fixed in sandy clay soils and was positively correlated with the soil organic carbon. This indicated that the content of $P$ released was readily available due to increase in soil organic matter to the soil. Poorly structured soils like sandy clay were improved following the increase in soil organic carbon content released from the decomposition and mineralization of the added mulches, and hence improving the soil fertility (Adekiya et al., 2017; Agbede et al., 2014). Coffee yield can be increased with increasing soil organic carbon, total $\mathrm{N}$ and $\mathrm{P}$ concentrations (Wang et al., 2015).

At Kibirizi and Ruli, the retention and fixation of phosphorus in the soils have limited its availability due to high exchangeable acidity as it was also reported by Van der Eijk et al. (2006). Application of lime is recommended to precipitate the exchangeable Al by increasing the exchangeable Ca content, and thus increase P availability (Carducci et al., 2015; Van der Eijk et al., 2006). Although lime may increase the availability of $P$, it cannot compensate for 
$\mathrm{P}$ deficiencies at these sites; thus, additional applications of inorganic $\mathrm{P}$ fertilizers are needed for this purpose.

\subsubsection{Effect of mulching on cations}

The effects of mulch demonstrated low to moderate retention capacity of the major soil nutrients, mainly $\mathrm{K}, \mathrm{Ca}$ and $\mathrm{Mg}$, hence indicating low to moderate soil fertility (Murphy et al., 2016). The $\mathrm{Ca}$ and $\mathrm{Mg}$ levels were positively correlated, and were also correlated with the available $\mathrm{P}, \mathrm{K}$, and $\mathrm{Na}$. $\mathrm{Ca}$ and $\mathrm{Mg}$ were negatively correlated with $\mathrm{Al}$ and exchangeable acidity. Consequently, this has affected the ECEC and the base saturation. The low base saturation was significantly affected by the increase in the soil Al saturation at Kibirizi and Ruli. Positive correlation between $(\mathrm{Ca}+\mathrm{Mg}) / \mathrm{K}$ and base saturation indicates possibilities to raise $\mathrm{Ca}$ and $\mathrm{Mg}$ contents of the soils by liming to precipitate the exchangeable acidity and Al (Bekunda et al., 2010; Carducci et al., 2015). For soils of Rwanda, 70\% of base saturation can reduced $\mathrm{Al}$ saturation to less than $20 \%$, and create a conducive environment to retain available soil nutrients (Mbonigaba et al., 2009; Mbonigaba, 2007). Our results also confirmed this trend, mainly at Karongi. Furthermore, the concentration of ( $\mathrm{Ca}+\mathrm{Mg}) / \mathrm{K}$ was negatively correlated with $\mathrm{K}$ contents, suggesting a need for additional inorganic $\mathrm{K}$ to increase the ECEC. A slight increase in the ECEC was found, particularly after application of T3, T4 and T5. Long-term soil management practices to increase this ECEC should be first to raise the soil $\mathrm{pH}$ by liming. At the same time, liming will increase the contents of $\mathrm{Ca}$ and $\mathrm{Mg}$ to eliminate the $\mathrm{Al}$ and the exchangeable acidity that have immobilized $\mathrm{C}, \mathrm{N}$, and $\mathrm{P}$ (Bekunda et al., 2010; Carducci et al., 2015). Thereafter, the potassium (K) could be raised by fertilizer input after liming, if immediate effects on coffee yield are expected.

\subsubsection{Effect of mulching coffee yield}

Coffee yields were increased up-to $50 \%$ after three years of annual mulch application at a rate of 15 to $21 \mathrm{t} \mathrm{ha}^{-1}$. The highest yield (1.9 t of green coffee $\mathrm{ha}^{-1} \mathrm{yr}^{-1}$ ) was observed at Karongi, where agro-ecological conditions for growing coffee are favourable. At Kibirizi and Ruli, coffee yields were affected by environmental factors such as low temperature, high rainfall, and high altitude in addition to high Al saturation and low soil fertility status. In Uganda, Wang et al. (2015) found that elevation was a strong limitation factor to coffee yield, whereas in Ethiopia, Bote et al. (2018) reported nitrogen limitation and shading to reduce significantly coffee yield. Our results demonstrated that the coffee yield was positively influenced by an increase in base saturation and soil $\mathrm{pH}$. The increase in coffee yield due to mulch application could be attributed to reduced soil acidity and increased 
availability of SOC, total $\mathrm{N}$, available $\mathrm{P}$, exchangeable $\mathrm{K}, \mathrm{Ca}$ and $\mathrm{Mg}$ concentrations. This is in agreement with findings in related studies (Cordingley, 2009; Van der Vossen, 2005; Wang et al., 2015).

Coffee yields in the Rwandan smallholder farming system ranged from 1.0 to $1.9 \mathrm{t}$ of green coffee ha ${ }^{-1}$ year $^{-1}$ after mulching. Coffee yields close to 1.0 t of green coffee ha ${ }^{-1}$ year $^{-1}$ are considered low, whereas those above $1.8 \mathrm{t} \mathrm{ha}^{-1}$ year $^{-1}$ are high (Nzeyimana et al., 2014). Coffee yields are known to be limited by soil acidity and deficiencies in N, P, and K, key nutrients in development of the coffee plant and coffee berries (Cordingley, 2009; Wang et al., 2015). In Uganda, coffee yields varying between 0.2 and $2.2 \mathrm{t}$ of green coffee ha ${ }^{-1}$ year $^{-1}$ were reported for large scale monoculture farming and smallholder farming systems (Van Asten et al., 2011; Van der Vossen, 2005; Wairegi and van Asten, 2012; Wang et al., 2015). Coffee yields of less than $1 \mathrm{t}$ of green coffee ha- $\mathrm{year}^{-1}$ have been reported with little to none application of inorganic fertilizers (Shively and Hao, 2012). Significant yield could be obtained by combining mineral and organic fertilization to boost the production (Gentile et al., 2013; Liu et al., 2017; Santos et al., 2012; Tully et al., 2015; Wang et al., 2015).

\subsubsection{Fertilizer recommendations to improve coffee yield}

Our results demonstrated that soil nutrient levels increased with the amount of mulch applied, leading to improved soil fertility conditions and coffee yield. However, this also will require more land that needs to be mobilized to produce such huge amounts of mulch biomass. Rwandan land constraint (average landholdings per household is less than 1 ha) and the cost of labour to produce and transport huge amounts of mulch biomass may limit the applicability of this technology to maintain and improve the soil fertility conditions, and coffee yields. The combination of organic mulch and mineral fertilization is then needed (Gentile et al., 2013; Liu et al., 2017; Santos et al., 2012; Tully et al., 2015; Wang et al., 2015). Taking into account the various types and amounts of mulching materials applied at each site, and the concentrations of the nutrients released into the soils, nutrients' gaps can be closed by implementing site-specific additional inorganic fertilizer recommendations. This is in agreement with similar findings (De Bauw et al., 2016; Wairegi and van Asten, 2012).

For Rwanda, based on coffee nutrients' requirements of $44 \mathrm{~N}, 5.2 \mathrm{P}, 20 \mathrm{~K}, 1072 \mathrm{Ca}$ and 482 $\mathrm{Mg} \mathrm{kg} \mathrm{ha}{ }^{-1} \mathrm{yr}^{-1}$ (Cordingley, 2009), addition of inorganic fertilizer inputs applied as NPK fertilizer (14-5-9) at 200kg ha ${ }^{-1}$ with addition of lime (Ca: $58 \%$ and $\mathrm{Mg}$ : $15.5 \%$ ) applied at 2.5 $\mathrm{t} \mathrm{ha}^{-1}$ is recommended for Kibirizi, and for the southern zone in general. For Ruli, and in general for the northern zone, $200 \mathrm{~kg} \mathrm{ha}^{-1}$ of NPK fertilizer (17-5-11) and $2.5 \mathrm{t} \mathrm{ha}^{-1}$ of lime (Ca: $57 \%$ and $\mathrm{Mg}$ : $15 \%$ ) is recommended. For Karongi, and the western zone in general, the 
NPK fertilizer (16-4-10) and lime (Ca: 58\% and Mg: 15\%) is recommended. P and Ca could also be supplied through rock phosphates or phosphorus fertilizer. These fertilization rates are far very low compared to those used by big coffee producer countries in Latin-America. To boost high coffee yields and income in Ecuador, Capa et al. (2015) demonstrated that medium and high fertilization rates (over $150 \mathrm{~N}, 44 \mathrm{P}$ and $62 \mathrm{~K} \mathrm{~kg} \mathrm{ha}^{-1} \mathrm{yr}^{-1}$ in the first year and $300 \mathrm{~N}, 87 \mathrm{P}$ and $125 \mathrm{~K} \mathrm{~kg} \mathrm{ha}^{-1} \mathrm{yr}^{-1}$ for the second year) could not allow an environmental and economic sustainability of monoculture coffee farming. Conversely, fertilization rates of about $70 \mathrm{~N}, 22 \mathrm{P}$ and $31 \mathrm{~K} \mathrm{~kg} \mathrm{ha}^{-1} \mathrm{yr}^{-1}$ in the first year and $200 \mathrm{~N}, 65 \mathrm{P}$ and $62 \mathrm{~K} \mathrm{~kg} \mathrm{ha}^{-1} \mathrm{yr}^{-}$ ${ }^{1}$ for the second year were recommended (Capa et al., 2015).

\subsection{Conclusion}

- Coffee farming system under permanent mulching system should be considered as part of the improved soil management technologies;

- Mulching strongly improved soil nutrient levels, base saturation and SOM content; however, the effects were site specific. The mulching composed of Cymbopogon spp. mixed with Panicum spp and Cymbopogon spp. mixed with Eucalyptus spp. strongly decreased soil acidity, whereas mulching composed of mixed crop residues significantly improved soil fertility status and increased coffee yields, thus it should be recommended to farmers;

- The amount of nutrient contents released during mulch decomposition was regulated by the amount of mulch biomass applied, the quality and type of mulch used, and the agro-ecological (environmental) conditions of the specific study site;

- Taking into account the various types and amount of mulching materials applied at each site, the concentrations of the nutrients released into the soils did not fulfill the coffee nutrients' requirements to boost high coffee yield; thus, the use of inorganic fertilizers is recommended to close the nutrients' gaps. The inorganic fertilizer rates differ for each agro-ecological zone (i.e. environmental factor) and soil type. 
6. Synthesis 


\subsection{Introduction}

Coffee is one of the most important agricultural commodities globally, and serves as a major foreign exchange earner in many developing countries. In the Eastern and Central African countries, like Ethiopia, Kenya and Rwanda, coffee is one of the top export commodities in agriculture that contribute to the national economy.

In Rwanda, coffee production is a predominant activity of smallholder farmers and these are usually grouped into cooperatives in order to improve coffee quality and their overall access to markets that in turn improves their income. The cooperatives can compete and directly negotiate best coffee prices with international buyers based on the quality of their coffee. The Government of Rwanda is planning to improve farming livelihood through the sustainable production of high quality coffee. Among other challenges, soil fertility depletion and soil erosion are the main factors affecting sustainable productivity of coffee in Rwanda, where most of the coffee is on steep slopes that can sometimes exceed $55 \%$ (Nzeyimana et al., 2014).

The aim of this study is to develop best land management options for smallholder coffee farming in Rwanda in order to ensure sustainable coffee production. For decision and policy makers, this study provides information and key strategies that bring about changes towards sustainable growth of high quality coffee. It is hypothesized that smallholder coffee farms have low yield but with improved soil fertility of the poorly managed coffee fields and controlling soil erosion, coffee yields can be increased, and therefore farmers' revenues and livelihoods can be improved.

The study approach described in the previous chapters are synthesised in Figure 6.1. The approach used describes the problem analysis, which starts with a GIS spatial analysis at national level to identify and characterize major coffee production zones. Then, zooming in at farm level, this study analyses and presents experimental results on the effects of different mulching systems, which were identified at farm level, on soil erosion control and soil fertility improvement. Finally, the study proposes best land management options that can be scaled-up to the country level to ensure sustainable coffee production. The study sites used present different agro-ecological conditions for growing Arabica coffee in Rwanda, and are part of the major production zones. 


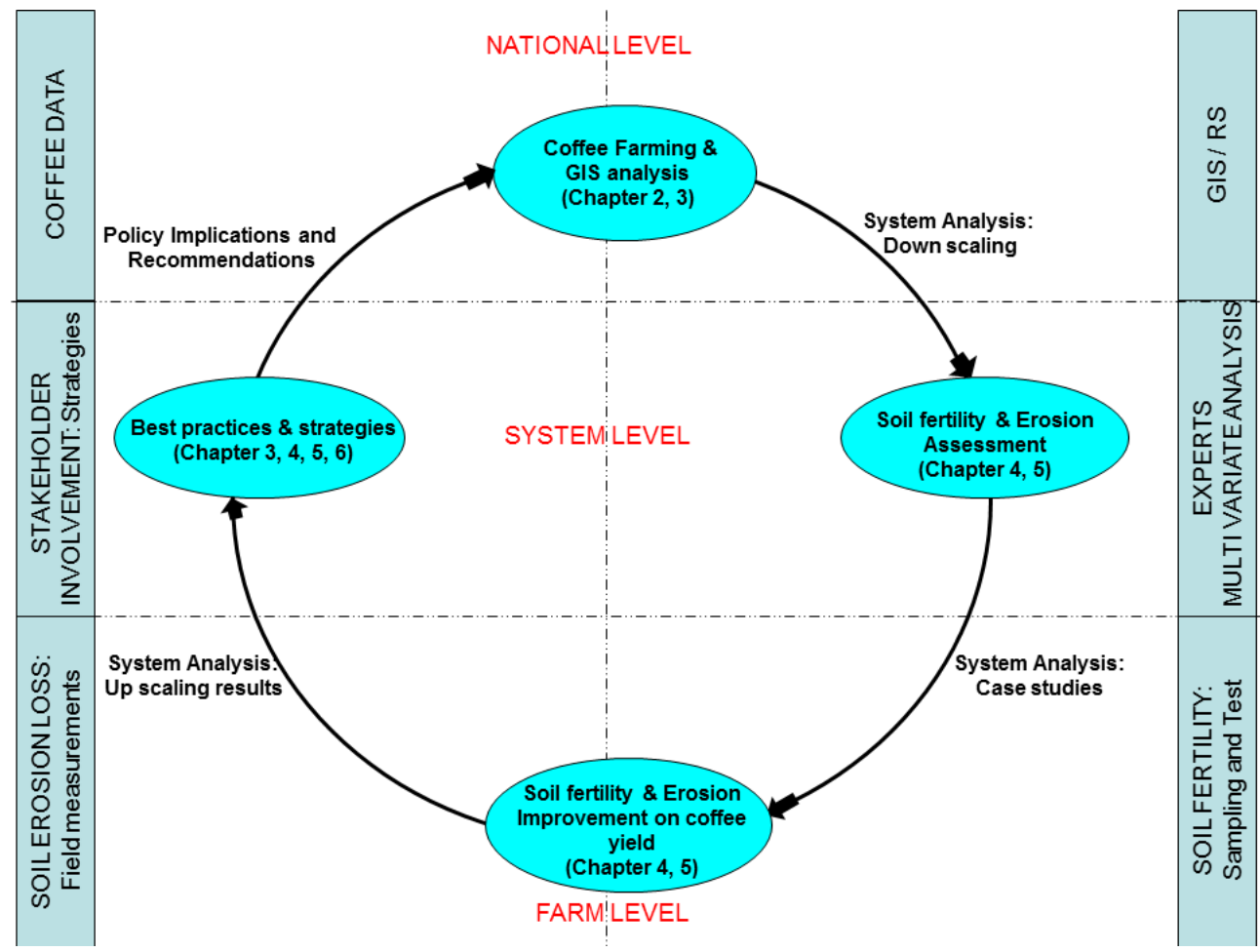

Figure 6.1 Flow chart illustrating the study approach and scale levels used in this study

\subsection{Main Findings}

To achieve the above overall goal, soil erosion control and soil fertility were studied in three major coffee production zones of Rwanda. There were four (4) main research questions (RQ) that provided the understanding on the best land management practices for "Optimizing Arabica coffee production systems in Rwanda".

On the issue of getting clear understanding of the major areas for Arabica coffee production and their bio-physical characteristics in Rwanda, this research found that Arabica coffee is mainly produced in three major zones, which are determined by agro-ecological factors, including soil management practices and in particular mulching. The major production areas are characterized by three levels of coffee productivity potentials, dominated by moderate to high productivity potential varying between 1 and $2.4 \mathrm{t} \mathrm{ha}^{-1}$ (Chapter 3). In Rwanda, a wide range of coffee productivity has been reported, and is varying between 0.8 and $2.8 \mathrm{t}$ $\mathrm{ha}^{-1}$, but yields above $2.8 \mathrm{t} \mathrm{ha}^{-1}$ are rare even with adequate fertilization and sustained crop 
management (Nzeyimana et al., 2013). The national average of actual coffee productivity is estimated at $1.1 \mathrm{t} \mathrm{ha}^{-1}$ (Chapter 3 ).

Findings also indicated that mulching, as the major land management practice, significantly increased soil organic carbon and wet aggregate stability, and reduced soil bulk density. Soil erodibility was reduced with improved wet aggregate stability and increased soil organic carbon content (Chapter 4). However, the effects of mulching on soil chemical properties and soil fertility improvement were influenced by the quality of the mulches, depending on the site and the agro-ecological conditions (Chapter 5 ).

Importantly, we verified that Arabica coffee yield could be increased after reducing soil erosion and improving soil fertility. The findings indicated that mulching has the potential to increase coffee yields from less than $1 \mathrm{t} \mathrm{ha}^{-1}$ to $1.9 \mathrm{t} \mathrm{ha}^{-1}$ in the study sites (Chapter 5), which serves as a good sign considering that this is $1.1 \mathrm{t} \mathrm{ha}^{-1}$ above the national average.

Highlights of the findings for each research question are presented in the following subsections.

\subsubsection{RQ1 - Major areas for Arabica coffee production in Rwanda - their bio- physical characteristics}

In Rwanda, findings from this study showed that the major coffee production areas account for $80 \%$ of the total area used for coffee production. These include the Central Plateau (32\%), the Eastern Plateau and Mayaga regions (26\%), and the Lake Kivu region (22\%), which covers the Lake Kivu shores, "Impala" and "Imbo" zones (Chapter 3). Much of this area is located on slopes varying between 25 and 55\%, where other annual crops are also grown in competition or intercropping with coffee due to limited agricultural land and limited availability of mulch biomass. Available mulches used in the coffee farming are from Eucalyptus branches, Grevillea branches, sorghum thatches, panicum spp., cymbopogon spp., sugar cane leaves, banana leaves and mixed residues, which are also in competition with other usages by the smallholder farmer (Chapter 2).

The Central Plateau is characterized by a wide range of soil types developed from schistose and granitic materials. Its landscape is characterized by moderate and steep slopes that can affect the productivity of the region due to soil erosion. The Eastern Plateau and Mayaga is characterized by low to middle altitudes, infertile soils derived from schistose and granitic materials like Oxisols and Ultisols, moderate slopes, very high temperatures, and low rainfall that offer limited conditions for coffee productivity. 
The Lake Kivu region has fertile soils (Inceptisols, Andisols and Alfisols), moderate slopes and altitudes, and has favourable climate characterized by abundant rainfall and moderate temperatures. As also reported by Verdoodt and Van Ranst (2003), the Lake Kivu region has alluvial and very fine clayey soils, developed from basalt with high agricultural potential. This indicates that the Lake Kivu region has potential for high coffee production and productivity. This also suggests that Arabica coffee production could be expanded in these zones to ensure more sustainable production for the country, particularly for export.

\subsubsection{RQ2 - Potential and expected productivity indices in major areas for Arabica coffee production (and implications for expansion)}

The Arabica coffee production areas have been analysed using GIS spatial analysis tools (i.e. multi-criteria analysis) to assess potential production zones and productivity levels. The qualitative analysis indicated three zones with high, moderate, and low productivity potentials. Approximately $80 \%$ of the total national coffee coverage had moderate to high productivity potential. Zones with high potential cover about $40 \%$, and include the "Lake Kivu shores", Impala and "Imbo" agro-ecological zones (Chapter 3).

The Central Plateau, the highland zones, and the eastern lowland zones are areas with both moderate and low productivity indices. The productivity in the Central Plateau zone is mainly limited by the bio-physical characteristics as described above. The cold and humid conditions, heavy rainfall, very low temperatures, moderate and steep slopes ( $25-55 \%$ ) indicated sub-optimum conditions for potential coffee productivity in the highlands like "Birunga", "Buberuka" and "Congo-Nile Watershed Divide" agro-ecological zones. The eastern lowlands include the dry Eastern Plateau and Savanna agro-ecological zones. Such unsuitable climatic conditions affected the development and maturity of the berries, and thus limited the coffee productivity (Chapter 3 ).

\subsubsection{RQ3 - Effects of mulching on soil erosion control and fertility improvement}

The results of this study revealed that the mulching materials were effective in reducing soil erodibility at the three major Arabica coffee production areas, namely the Lake Kivu, the Congo-Nile Watershed highlands, and the Central Plateau. Mulch significantly increased soil organic carbon and wet aggregate stability, and reduced soil bulk density. Soil erodibility is reduced with improved wet aggregate stability and increased soil organic carbon content 
(Chapter 4). The effects were different, depending on the bio-physical conditions of the site, and the types of mulch collected from the site (Chapter 4).

At these zones, low bulk densities as well as high soil organic carbon and wet aggregate stability values were observed, particularly in response to the application of Eucalyptus spp. mixed with Cymbopogon spp., and the mixed residues. These two mulching materials were more effective in reducing soil erodibility than other types of mulching materials particularly on clay and silt soils. These mulches reduced runoff speed, and increased the infiltration rate. The interactions between bulk density, soil organic carbon content, soil texture, and soil aggregate stability require further analysis in order to understand how soil erodibility could be assessed and is affected by the quality of the mulches (Chapter 4).

Our findings on the effects of mulching on soil fertility improvement revealed that the quality of mulch contributed to reduce soil acidification (Chapter 5). At the Congo-Nile Watershed highlands and the Lake Kivu zones, mulch of Cymbopogon spp. mixed with Panicum spp., Eucalyptus spp. mixed with Cymbopogon spp., and mixed residues reduced exchangeable soil acidity by 40 and $42 \%$, respectively. At the Central Plateau, similar results were obtained with the application of mixed residues, and exchangeable soil acidity was reduced by $43 \%$. These trends were also related to soil texture, particularly on well-drained sandy loam soils of the Lake Kivu agro-ecological zone, where the climate influenced decomposition and mineralisation of organic materials, particularly the mixed crop residues.

The effects of mulching on soil chemical properties and soil fertility were influenced by the bio-physical conditions of the production site and the quality of the mulches collected from the site (Chapter 5). Repeated dry-wet cycles enhanced microbial degradation of the organic mulches added to the soils, which resulted in increased mobilisation of major nutrients, particularly N, P, K, Ca and Mg, leading to higher soil fertility (Chapter 5). At the highlands of the Congo-Nile Watershed Divide zone, where the climate is cold and humid, high soil acidification was observed on clay and loamy soils. Our data revealed that $\mathrm{C}$ and $\mathrm{N}$ released were more retained in clay soils than in sandy soils. These results showed that the effects of mulching on soil fertility improvement were influenced by the quality of mulch, the biophysical characteristics of the production area, and the soil types (Chapter 5).

\subsubsection{RQ4 - Effects of mulching on Arabica coffee yield}

The increased Arabica coffee yield was observed after reducing soil erosion (Chapter 4) and improving soil fertility through organic mulching (Chapter 5). Our findings indicated coffee 
yields increased from less than $1 \mathrm{t} \mathrm{ha}^{-1}$ to $1.9 \mathrm{t} \mathrm{ha}^{-1}$ when mulching was used (Chapter 5). Our data also confirmed that the effectiveness of mulching on coffee yield was influenced by the quality of the mulches applied, the soil type, and depended on the site location and the bio-physical conditions of the site where mulches were collected (Nzeyimana et al., 2017).

At the Lake Kivu agro-ecological zone, mulching with mixed residues or Cymbopogon spp. showed great potential in increasing coffee yield up-to 48\%, particularly on clay and sandy clay soils. At the Congo-Nile Watershed Divide agro-ecological zone, mulching with Cymbopogon spp. mixed with Panicum spp., and Panicum spp. alone increased coffee yields up-to $24 \%$.

\subsection{General discussion}

\subsubsection{Current production of Arabica coffee in Rwanda - Actual versus potential}

The distribution of the major production zones in Rwanda can be explained by biophysical factors such as soil type, soil properties, terrain (altitude, slope), soil management, and climatic conditions as reported by Kravchenko and Bullock (2000). In general, actual coffee productivity in the main growing regions falls below the potential as found in our research. The actual coffee productivity rates of the Central Plateau are estimated to be similar to those of the highland and the eastern lowland zones; on average that was estimated between 0.8 and $1.2 \mathrm{t} \mathrm{ha}^{-1}$, with a mean of $1 \mathrm{t} \mathrm{ha}^{-1}$, while their productivity potential does not exceed $1.3 \mathrm{t} \mathrm{ha}^{-1}$. These limited productivity potentials for growing Arabica coffee could be related to the bio-physical conditions of both the highlands and lowlands. In the highlands, particularly the Buberuka Highlands and Congo-Nile Watershed Divide zones, Arabica coffee productivity is limited by very low temperatures, heavy rainfall, and steep slopes (Verdoodt and Van Ranst, 2003), which could influence the depletion of soil fertility and reduce yields due to water erosion on the hills (discussed in Chapter 3). Besides, following the cold and humid climatic conditions of the highlands, this is likely contributed to nutrient immobilization (Bekunda et al., 2010; Fageria and Nascente, 2014), thus to coffee productivity limitation (discussed in Chapter 5).

In the lowlands, particularly the Eastern Plateau and Savanna, high temperatures, low altitudes, and low rainfall of the regions can cause water stress to the coffee and limit its productivity (Verdoodt and Van Ranst, 2003). In addition, the soils are acidic and characterized by poor soil fertility status (Rushemuka et al., 2014), and yet coffee 
productivity is known to be limited by soil acidity and deficiencies in $\mathrm{N}, \mathrm{P}$, and $\mathrm{K}$, key nutrients in development of the coffee plant and coffee berries (Cordingley, 2009; Wang et al., 2015). Arabica coffee requires at least soils with a pH of 4.5-6.0, moderate to high sums of basic cations, and 2-5\% organic matter to optimize productivity (Verdoodt and Van Ranst, 2003). The actual coffee productivity of the Lake Kivu region is estimated on average at 1.6 $\mathrm{t} \mathrm{ha}^{-1}$ while its productivity potential is between 1.6 and $2.4 \mathrm{t} \mathrm{ha}^{-1}$ and can be extended to $3.5 \mathrm{t} \mathrm{ha}^{-1}$ (Chapter 3 ). These production gaps and other findings from our research indicate that there are opportunities for increasing the production of Arabica coffee in Rwanda if sustainable land management practices are considered in coffee farming systems. The Lake Kivu region has favourable soil types and slopes with abundant rainfall and moderate temperatures to optimize coffee productivity (discussed in Chapter 3). The region has alluvial and very fine clayey soils, developed from basalt, and a high productivity potential (Verdoodt and Van Ranst, 2003).

The spatial variation of coffee productivity in the major production zones was considerable and was influenced by the bio-physical factors (i.e. soil properties and climatic conditions), soil management, and farming practices. Our multi-criteria analysis revealed that the biophysical characteristics are the main factors that influenced the coffee productivity rates (discussed in Chapter 3). In addition, in Rwanda, the low actual coffee productivity could be due to old coffee trees of current plantations that are associated to old coffee varieties, unsuitable climatic conditions for growing coffee, lack of proper soil management practices and soil erosion control measures in coffee farming systems, and low soil fertility status (discussed in Chapters 4 and 5). In Northern and Eastern Districts of Uganda, poor soil nutrient status (especially $\mathrm{K}, \mathrm{P}$ ), unfavourable soil properties like high soil $\mathrm{pH}$ and lack of mulching, were also reported as the main causes of low coffee productivity (Wang et al, 2015).

\subsubsection{The potential for mulch to increase yields in the current production areas}

The results of this study revealed that the effects of mulching were positive in controlling water runoff and soil erosion control, and thus improving soil fertility (discussed in Chapters 4 and 5). Similar observations have been reported by Fernández et al. (2012), Mwango et al. (2016), and Prosdocimi et al. (2016a). Improving soil fertility was not solely the result of reduced soil erodibility following mulching. Our results showed that the improved soil fertility was also influenced by the quality of mulch and the type of soil/soil texture (discussed in Chapter 5). 
The findings on the effects of mulching on soil fertility improvement (Chapter 5) support previous research findings such as Lalljee (2013), Herencia and Maqueda (2016), Ni et al. (2016), Adekiya et al. (2017), and Liu et al. (2017). The bio-physical decomposition and mineralization of the mulches has resulted in increased mobilisation of major nutrients, particularly N, P, K, Ca and Mg, leading to higher soil fertility (Chapter 5).

Previous studies reported that the faster the rate of decomposition of the organic mulch, the better the supply of nutrients (Abbasi et al., 2015; Giller et al., 2006; Herencia and Maqueda, 2016; Oliveira et al., 2014; Palm et al., 2001). However, such mobilisation was influenced by the bio-physical characteristics of the study site and the quality of the mulches collected from the site (Chapter 5).

Generally, the quality of mulch and the bio-physical conditions of the study site can affect mulch decomposition, and thus the nutrients' availability. Previous studies indicated that the cold and humid conditions induced slow decomposition of the mulches, as well as the solubility of the soil organic C and the availability of N (Abbasi et al., 2015; Agbede et al., 2014; Gentile et al., 2013). Such climatic conditions also increased soil acidification when the mulching materials applied are rich in polyphenols and lignin that decompose slowly (Abbasi et al., 2015; Giller et al., 2006; Herencia and Maqueda, 2016; Palm et al., 2001). In addition, we found that high soil acidity contributed markedly to the immobilisation of not only $\mathrm{N}$, but also $\mathrm{P}, \mathrm{K}, \mathrm{Ca}$ and $\mathrm{Mg}$. Consequently, this has resulted in low base saturation (discussed in Chapter 5). Our findings thus support research observations previously reported by Ding et al. (2014) and Ni et al. (2016). Thus liming is required to increase coffee yield in these acidic soils.

We found that the reduced soil erodibility and improved soil fertility from mulching resulted in increased coffee yields (discussed in Chapter 5). The results support similar research findings in Tanzania, where the yields of maize and beans significantly increased as a result of soil erosion control and soil fertility restoration through Tughutu mulch application (Mwango et al., 2016). Thus, the high coffee yields owing to mulching can be explained by the higher nutrients' concentrations contained in the organic materials applied as mulch, which later, are released to soils through decomposition. Similar general observations on the importance of mulching on improving coffee yield have been reported previously in Brazil (DaMatta and Ramalho, 2006). However, our findings demonstrated that mulching when applied alone was not sufficient for boosting coffee yields. Thus, soil fertility restoration through organic mulching should be combined with the use of inorganic fertilizers to improve coffee yield. The application rates of the mineral fertilisers differ per bio-physical conditions of the site and the soil texture (discussed in Chapters 4 and 5). 
Similar observations have been reported by Bucagu et al. (2013), Gentile et al. (2013), Tully et al. (2015), and Liu et al. (2017).

\subsubsection{Potential for expansion of sustainable production of high quality Arabica coffee in Rwanda}

In Rwanda, the sustainability of the coffee sector relies on increasing the productivity of high quality Arabica coffee to secure a sustainable rural livelihood of the smallholder farmers. The potential for expansion depends on improving coffee productivity in the major production areas. Our results showed that the Current Productivity Index (CPI) of Arabica coffee indicated that $80 \%$ of the country has moderate to high productivity potential, with $40 \%$ covering high potential zones (Chapter 3 ). These zones demonstrated favourable biophysical conditions for coffee expansion. However, the same results indicated that expansion in the high- and low-lands is not possible due to poor bio-physical conditions for production of high quality Arabica Coffee. Similar observations have been reported by Verdoodt and Van Ranst (2003). Thus, improving the productivity of zones of moderate to high productivity potential could be an opportunity for sustainable production of Arabica coffee.

Our results showed that the CPI of the Central Plateau and the Lake Kivu regions can be extended to 1.3 and $3.5 \mathrm{t} \mathrm{ha}^{-1}$, respectively (Chapter 3 ), with improved land management practices, i.e. good quality mulches that can mobilize high content of major nutrients, leading to improved soil fertility, and thus to increased yields (discussed in Chapters 4 and 5). Similar findings were reported by Borken and Matzner (2009) and Miura et al. (2013). Different mulches have different effects in supplying nutrient contents to soils; variations are depended on quality of mulching materials, climatic conditions and soil types (discussed in Chapters 5). Similar observations have been reported by Daraghmeh et al. (2009), Herencia and Maqueda (2016), Okur et al. (2016) and Liu et al. (2017). The smallholder farmers are usually in better position to identify good quality mulches that decompose faster (Chapter 2) to supply higher nutrients' concentrations (discussed in Chapter 5). At the Lake Kivu region, repeated dry-wet cycles of the region enhanced quick microbial degradation of the mulch, which resulted in improved soil fertility and increased coffee yields (discussed in Chapters 4 and 5). The region has also favourable bio-physical conditions that influence the optimization of coffee productivity (Verdoodt and Van Ranst, 2003).

Previous research findings on coffee productivity in Rwanda also confirmed increased coffee yields through application of good quality mulches like Tephrosia that supplied high nutrients' concentrations; the effect was even double when the Tephrosia mulch was 
combined with inorganic fertilizers (Bucagu et al., 2013), but not exceeding $0.7 \mathrm{t} \mathrm{ha}{ }^{-1}$. However, coffee yields reported by these authors were in comparison to the yields reported at the Central Plateau in our findings. We also noticed that their experimental trials were conducted within the same bio-physical conditions, i.e. at the Central Plateau, where coffee productivity was estimated on average between 0.8 and $1.2 \mathrm{t} \mathrm{ha}^{-1}$. Hence, sustainable production of Arabica coffee can be potentially extended also to major production areas through use of affordable land management practices like applying mulches of good quality (discussed in Chapter 5). Mulching is adopted by the smallholder farmers as one of the affordable and sustainable land management practices to maintain or restore soil fertility (Lalljee, 2013; Liu et al., 2017; Mwango et al., 2016), leading to improved crop productivity (Liu et al., 2017; Okeyo et al., 2014; Tao et al., 2015). Positive results are also expected, on the other hands, with the combination of mulching with mineral fertilizer application as also suggested by Gentile et al. (2013), Tully et al. (2015), and Liu et al. (2017). In Rwanda, the production of mulch biomass requires additional agricultural land, which is already scarce. Thus, the use of inorganic fertilizers is definitely recommended as an alternative to improve soil fertility and increase coffee productivity. The inorganic fertilizer rates differ for each agro-ecological zone and soil type (discussed in Chapter 5).

\subsection{Best practices}

Coffee yield can be optimized at farm level through adoption of sustainable and affordable land management practices like mulching. Mulching can then be adopted as best land management practices for smallholder coffee farmers with limited financial resources to invest in mineral fertilisers; at the same it should be adopted as a technology to reduce soil erosion for coffee trees grown on marginal lands. Coffee farmers can recognize best quality mulch that would contribute to improve the soil fertility of the farms; thus, the use of high quality mulch should be adopted and promoted as a sustainable management practice in smallholder coffee farming systems. Thus, such best land management practices should be adopted by smallholder coffee farmers to boost coffee productivity. However, the application of best quality mulch should consider combining all best agricultural practices like the application of organic mulching, liming and mineral fertilizer and adjusting the $\mathrm{pH}$ in acidic soils (discussed in Chapters 4 and 5). 


\subsection{Policy implications and recommendations}

\subsubsection{Improving coffee productivity in smallholder farming systems}

The Government of Rwanda has put in place a number of policy strategies that support the intensification of coffee production, the improvement of quality and its marketing system. The Government should continue to stimulate and support coffee expansion in areas with high yielding coffee production potential. Increased production should be achieved by replacing old coffee trees with new, high-yielding varieties in the high productivity areas, and applying the best management practices mentioned above.

Mobilisation of the programme can work at all levels through the community work, which is known in Rwanda as Umuganda (e.g. such as to have "Umuganda" for mulching and pruning for coffee). This can also be adopted as a strategic innovation to assist with productivity, and thus contribute to the reduction of poverty in smallholder farmers. It is suggested that farmers who adopt the best sustainable agricultural management practices should be rewarded and encouraged to bring others on board.

Additional issues include limited land for extensive agricultural, particularly coffee production; and there are calls for the Government of Rwanda to strategize specific quality coffee production (like the Rwandan new Nespresso "Umutima wa Lake Kivu"). The proposed sustainable interventions should be affordable for the poor farmers, and show scientific data to their success.

The Government should promote adoption of that good land management practices, and should ensure that farmers are well-trained and supported in this adoption, and that other issues such as soil erosion and lack of socio-economic support are effectively addressed. Further research should also ensure the technologies are used by the smallholder coffee farmers.

\subsubsection{Ensure sustainable rural livelihood for smallholder coffee farmers}

The Government should ensure sustainability of the coffee sector to secure a sustainable rural livelihood for smallholder farmers. Almost $100 \%$ of the coffee production in Rwanda is by smallholders, who contribute about $1 \%$ of the national GDP whereas the whole agriculture sector contributes about 33\% to the GDP in 2014 (NISR, 2015). This requires policy change at the country and global levels, especially at international trade level, to assist small coffee production countries becoming part of the global sustainable 
development. Key strategies to sustain the smallholder coffee farmers may include improved availability of appropriate coffee seedlings and fertilisers, providing on-farm training (through Farmer Field School - FFS), ensuring easy access to coffee markets, and ensuring access to financial services.

In addition, the Government of Rwanda (GoR), in partnership with private coffee trade companies, has adopted a model where the Government buys and distributes coffee seedlings and fertilisers to coffee farmers, and links the producers with a national private company that buys and collects the products from them for further processing or export to international coffee traders. The coffee farmers obtain the seedlings free of charge during mobilisation campaigns, which are led by the Government. Inorganic fertilisers are purchased by private coffee trade company and distributed to the smallholder coffee farmers with a Government subsidy of $75 \%$. The coffee farmer commits and accepts to pay the $25 \%$ of the cost of fertiliser at harvest time, through deductions made when the farmers sell the coffee cherries to the national coffee trade company. This system is implemented successfully by generating demand for seedlings and fertilisers and ensuring incomes to the smallholder coffee producers. However, such PPP model needs to be strengthened and supported enough by the Government in partnership with private sector, so that the smallholder coffee producers can enjoy it and generate more incomes to improve their livelihoods.

The GoR should also advocate for the uptake of these best practices and technologies to ensure a sustainable rural livelihood of the smallholder coffee farmers. The Government should also put in place adequate structures and mechanisms that enable smallholder coffee farmers to produce their own seedlings. This should be done by engaging pro-active cooperatives or coffee farmer promoters. Funding arrangements for seedlings' production should be negotiated in the same framework as for mineral fertilisers, which are purchased and distributed to the farmers by the coffee trade companies.

\subsubsection{Engage farmers in training on coffee productivity through Farmer Field Schools (FFS)}

The Rwanda agriculture sector uses an extension model called "Twigire Muhinzi", which is a Rwandese term to mean " farmer self-resiliency", which brings together two agricultural extension approaches: (a) Farmer promoters: these are selected farmers in rural communities, who are trained in agriculture extension to provide technical support to farmers in their localities through the farmer-to-farmer extension system; (b) The Farmer Field School (FFS) model, which uses a participatory extension approach to train farmers on 
the holistic management of specific crops. In the FFS model, farmers form FFS groups and use the "learn by doing" approach to conduct experimental trials on a single type of crop. The FFS groups learn to address various crop-specific constraints with local appropriate specific solutions. The "Twigire Muhinzi" extension system is also expected to improve knowledge, skills and information sharing between smallholder farmers. Currently, this model is not widely adopted in coffee production like in other commodities like banana and annual crops.

The "Twigire Muhinzi" extension system should be adopted as an extension approach to increase coffee production and productivity. Considerable focus should be directed towards farmers' training and mobilisation to establish coffee Farmer Field Schools, to create awareness on the value of adopting the innovation approaches that aim at improving soil fertility, and thus enhance coffee productivity. Through this, smallholder coffee farmers will be mobilised to more easily access mineral fertiliser through agro-dealers who have contracts with the coffee trade companies. Through FFS, farmers will learn how to produce good coffee seedlings and adopt recommended best coffee and land husbandry practices to increase coffee productivity.

\subsection{Limitations of the research and recommendations for further research}

Although the study came up with some interesting results, important for the scientific environment and farmer practice, some key limitations should be highlighted:

- This study attempted to find nationwide suitable areas for Arabica coffee production using a qualitative methodology. The method developed and applied demonstrated its robustness to run spatial and geo-statistical analysis. However, it must be clear that this research did not make any attempt to analyse existing spatial analysis methodologies to make them for instance more efficient or simple.

- Due to the variability in small scale farming systems, it was rather difficult to find experimental coffee plots that fulfilled exactly similar field conditions in the three agroecological zones where field experimentations were conducted.

- The study demonstrated the potential of mulching coffee, however, with the specific objectives set for this research, it was difficult to exhaust all issues that would help to understand the potential for optimizing Arabica coffee production systems in Rwanda, like the identification of rates of mulch biomass and inorganic fertilizers required to optimize coffee productivity, and the role of water productivity to improve coffee yield. 
Besides these constraints and the research findings highlighted in this study, a number of issues need to be addressed further in order to clearly understand the potential to optimize Arabica coffee production systems in Rwanda:

- Predicting coffee productivity through mapping of soil fertility indicators

- Modelling soil erosion of scattered smallholder coffee farms at micro-catchment level

- Assessing the quality of the organic mulches applied in small scale coffee farming systems, their liming effects, inreased soil fertility through mineralisation of $\mathrm{C}$ and $\mathrm{N}$, and their integrated impacts on coffee productivity. 


\section{Literature cited}

Abbasi, M.K., M.M. Tahir, N. Sabir and M. Khurshid 2015. Impact of the addition of different plant residues on nitrogen mineralization-immobilization turnover and carbon content of a soil incubated under laboratory conditions. Solid Earth 6: 197-205.

Adekalu, K.O., D.A. Okunade and J.A. Osunbitan 2006. Compaction and mulching effects on soil loss and runoff from two southwestern Nigeria agricultural soils. Geoderma 137: 226-230.

Adekiya, A.O., T.M. Agbede, C.M. Aboyeji and O. Dunsin 2017. Response of okra (Abelmoschus esculentus (L.) Moench) and soil properties to different mulch materials in different cropping seasons. Scientia Horticulturae 217: 209-216.

Agbede, T.M., A.O. Adekiya and J.S. Ogeh 2014. Response of soil properties and yam yield to Chromolaena odorata (Asteraceae) and Tithonia diversifolia (Asteraceae) mulches. Archives of Agronomy and Soil Science 60: 209-224.

Anderson, J. and J.S.I. Ingram 1993. Tropical Soil Biology and Fertility: A Handbook of Methods. Second Edition. Oxford, USA: CAB International.

Angima, A.D., D.E. Stott, M.K. O’Nell, C.K. Ong and G.A. Weesies 2003. Soil erosion prediction using RUSLE for central Kenyan Highland conditions. Agriculture, Ecosystems and Environment 97: 295-308.

Annabi, M., Y. Le Bissonnais, M. Le Villio-Poitrenaud and S. Houot 2011. Improvement of soil aggregate stability by repeated applications of organic amendments to a cultivated silty loam soil. Agriculture, Ecosystems and Environment 144: 382-389.

Araya, A. and L. Stroosnijder 2010. Effects of tied ridges and mulch on barley (Hordeum vulgare) rainwater use efficiency and production in Northern Ethiopia. Agricultural Water Management 97: 841-847.

Arthur, E., W.M. Cornelis, J. Vermang and E. De Rocker 2011. Effect of compost on erodibility of loamy sand under simulated rainfall. Catena 85: 67-72.

Ataroff, M. and M. Monasterio 1997. Soil erosion under different management of coffee plantations in the Venezuelan Andes. Soil Technology 11: 95-108.

Awopegba, M., S. Oladele and M. Awodun 2017. Effect of mulch types on nutrient composition, maize (Zea mays L.) yield and soil properties of a tropical Alfisol in Southwestern Nigeria. Eurasian Journal of Soil Science 6: 121-133.

Baggie, I., D.L. Rowell, J.S. Robinson and G.P. Warren 2004. Decomposition and phosphorus release from organic residues as affected by residue quality and added inorganic phosphorus. Agroforestry Systems 63: 125-131. 
Beenart, F.R. 1999. Feasibility Study of Production of Lime and/or Ground Travertine for the Management of Acid Soils in Rwanda. Brussels, Belgium: Pro-Inter Project Consultants.

Bekunda, M., N. Sanginga and P.L. Woomer 2010. Restoring Soil Fertility in Sub-Sahara Africa. Advances in Agronomy 108: 183-236.

Bigirimana, J., K. Njoroge, D. Gahakwa and N.A. Phiri 2012. Incidence and severity of coffee leaf rust and other coffee pests and diseases in Rwanda. African Journal of Agricultural Research 7: 3847-3852.

Birasa, E.C., I. Bizimana, W. Bouckaert, A. Delflandre, J. Chapelle, A. Gallez, G. Maesschalck and J. Vercruysse 1990. Les Sols du Rwanda: méthodologie, légende et classification. In Les Sols du Rwanda: méthodologie, légende et classification, Carte Pédologique du Rwanda. Kigali - Rwanda (Unpublished): CTB et MINAGRI.

Bizoza, A. R. and J. de Graaf 2012. Financial cost-benefit analysis of bench terraces in Rwanda. Land Degradation and Development 23 (2): 105-115.

Blavet, D., G. De Noni, Y. Le Bissonnais, M. Leonard, L. Maillo, J.Y. Laurent, J. Asseline, J.C. Leprun, M.A. Arshad and E. Roose 2009. Effect of land use and management on the early stages of soil water erosion in French Mediterranean vineyards. Soil and Tillage Research 106: 124-136.

Boffa, J.M., L. Turyomurugyendo, J.P. Barnekow-Lilleso and R. Kindt 2009. Enhancing farm tree diversity as a means of conserving landscape-based biodiversity. Mountain Research and Development 25: 212-217.

Bonilla, C.A. and O.I. Johnson 2012. Soil erodibility mapping and its correlation with soil properties in Central Chile. Geoderma 189-190: 116-123.

Borken, W. and E. Matzner 2009. Reappraisal of drying and wetting effects on C and $\mathrm{N}$ mineralization and fluxes in soils. Global Change Biology 15: 808-824.

Borkhataria, R., J.A. Collazo and M.J. Groom 2012a. Species abundance and potential biological control services in shade vs. sun coffee in Puerto Rico. Agriculture, Ecosystems and Environment 151: 1-5.

Borkhataria, R., J.A. Collazob, M.J. Groomc and A. Jordan-Garciab 2012b. Shade-grown coffee in Puerto Rico: Opportunities to preserve biodiversity while reinvigorating a struggling agricultural commodity. Agriculture, Ecosystems and Environment 149: 164170.

Bosselmann, A. S., K. Dons, T. Oberthur, C. S. Olsen, A. Ræbild and H. Usma 2009. The influence of shade trees on coffee quality in small holder coffee agroforestry systems in southern Colombia. Agriculture, Ecosystems and Environment 129: 253-260.

Bot, A. and J. Benites 2005. The importance of soil organic matter: Key to drought-resistant soil and sustained food production. In The importance of soil organic matter: Key to drought-resistant soil and sustained food production, FAO Soils Bulletin No 80. Rome: FAO. 
Bote, A.D., Z. Zana, F.L. Ocho and J. Vos 2018. Analysis of coffee (Coffea arabica L.) performance in relation to radiation level and rate of nitrogen supply II. Uptake and distribution of nitrogen, leaf photosynthesis and first bean yields. European Journal of Agronomy 92: 107-114.

Brady, N.C. and R.R. Weil 2002. The nature and properties of soils. New Jersey: Pearson Education Inc., Upper Saddle River.

Bruno, I.P., K. Reichardt, R.P. Bortolotto, V.M. Pinto, O.O.S. Bacchi, D. Dourado-Neto and M.J. Unkovich 2015. Nitrogen balance and fertigation use efficiency in a field coffee crop. Journal of Plant Nutrition: 2055-2076.

Bucagu, C., B. Vanlauwe and K.E. Giller 2013. Managing Tephrosia mulch and fertilizer to enhance coffee productivity on smallholder farms in the Eastern African Highlands. European Journal of Agronomy 48: 19-29.

Capa, D., J. Perez-Esteban and A. Masaguer 2015. Unsustainability of recommended fertilization rates for coffee monoculture due to high N2O emissions. Agronomy for Sustainable Development 35: 1151-1559.

Carducci, C.E., G.C. Oliveira, N. Curi, R.J. Heck, D.F. Rossoni, T.S. de Carvalho and A.L. Costa 2015. Gypsum effects on the spatial distribution of coffee roots and the pores system in oxidic Brazilian Latosol. Soil and Tillage Research 145: 171-180.

Cerdà, A., Ó. González-Pelayo, A. Giménez-Morera, A. Jordán, P. Pereira, A. Novara, E.C. Brevik, M. Prosdocimi, M. Mahmoodabadi, S. Keesstra, F. García-Orenes and C.J. Ritsema 2016. Use of barley straw residues to avoid high erosion and runoff rates on persimmon plantations in Eastern Spain under low frequency - high magnitude simulated rainfall events. Soil Research 54: 154-165.

Changere, A. and R. LaL 1997. Slope position and erosional effects on soil properties and corn production on a Miamian soil in Central Ohio. Journal of Sustainable Agriculture 11: 5-21.

Clay, J. 2004. Coffee. In World Agriculture and the Environment, ed. J Clay. Washington: Island press.

Coleman, A.L. and J.M. Galbraith 2000. Using GIS as an Agricultural Land Use Planning Tool. In Using GIS as an Agricultural Land Use Planning Tool, Department of Crop and Soil Environmental Science, Virginia Tech. Blacksburg. Bulletin No 2. Available at http://scholar.lib.vt.edu/ejournals/vaes/00-2.pdf. Accessed 11 Feb. 2014.

Cordingley, J. 2009. Soil Fertility Survey of Rwandan Coffee Sector. In Soil Fertility Survey of Rwandan Coffee Sector, ed. Crop Nutrition Laboratory Services. Nairobi.

Coste, R. 1989. Caféier et Cafés. Paris: Maisonneuve et Larose.

D'haeze, D., J. Deckers, D. Raes, T.A. Phong and H.V. Loi 2005. Environmental and socioeconomic impacts of institutional reforms on the agricultural sector of Vietnam: Land suitability assessment for Robusta coffee in the Dak Gan region. Agriculture, Ecosystems and Environment 105: 59-76. 
DaMatta, F.M. and J.D.C. Ramalho 2006. Impacts of drought and temperature stress on coffee physiology and production: a review. Brazilian Journal of Plant Physiology 18: 55-81.

Daraghmeh, O.A., J.R. Jensen and C.T. Petersen 2009. Soil structure stability under conventional and reduced tillage in a sandy loam. Geoderma 150: 64-71.

De Bauw, P., P. Van Asyen, L. Jassogne and R. Merckx 2016. Soil fertility gradients and production constraintsfor coffee and banana on volcanic mountain slopes in the East African Rift: A case study of Mt. Elgon. Agriculture, Ecosystems and Environment 231: 166-175.

De Graaff, J. 1986. The economics of coffee. Economics of crops in developing countries. Pudoc: Wageningen.

De La Rosa, D., J.A. Moreno, L.V. Garcia and J. Almorza 1992. MicroLEIS: a Micro ComputerBased Mediterranean Land Evaluation Information System. Soil Use and Management 8: 89-96.

De Souza, H.N., R.G.M. De Goede, L. Brussaard, I.M. Cardoso, E.M.G. Duarte, R.B.A. Fernandes, L.C. Gomes and M.M. Pulleman 2012. Protective shade, tree diversity and soil properties in coffee agroforestry systems in the Atlantic rainforest biome. Agriculture, Ecosystems and Environment 146: 179-196.

Descroix, F. and J. Snoeck 2004. Coffee: Growing, Processing, Sustainable Production. In A Guidebook for Growers, Processors, Traders, and Researchers, ed. J N Wintgens, 164177. Switzerland.

Diggle, P.J. and P.J.Jr. Ribeiro 2007. Model-Based Geostatistics. New York: Springer.

Ding, X., Y. Yuan, Y. Liang, L. Lujun and H. Xiaozeng 2014. Impact of long-term application of manure, crop residue, and mineral fertilizer on organic carbon pools and crop yields in a Mollisol. Journal of Soils and Sediments 14: 854-859.

Duiker, S.W., D.C. Flanagan and R. Lal 2001. Erodibility and infiltration characteristics of five major soils of southwest Spain. Catena 45: 103-121.

Duiker, S.W. and R. Lal 1999. Crop residue and tillage effects on carbon sequestration in a Luvisol in central Ohio. Soil and Tillage Research 52: 73-81.

Edwards, L., J.R. Burney, G. Richter and A.H. MacRae 2000. Evaluation of compost and straw mulching on soil-loss characteristics in erosion plots of potatoes in Prince Edward Island, Canada. Agriculture, Ecosystems and Environment 81: 217-222.

Eijkelkamp 2010. Catalogue: Soil, Water, Crop, Agro-Climate, Physical Survey. In Catalogue: Soil, Water, Crop, Agro-Climate, Physical Survey. Wageningen, The Netherlands: Sludge \& Slurry.

Elliot, W.K., A.M. Liebenow, J.M. Laflen and K.D. Kohl 1989. A compendium of soil erodibility data from WEPP cropland: Soil field erodibility experiments for 1987 and 1988. Indiana: West Lafayette. 
ESRI 2011. ArcGIS Desktop: Realease 10. In ArcGIS Desktop: Realease 10. Redlands, CA: Environmental Systems Research Institute.

ESRI 2001. ArcGIS Spatial Analyst: Advanced GIS Spatial Analysis Using Raster and Vector Data. In ArcGIS Spatial Analyst: Advanced GIS Spatial Analysis Using Raster and Vector Data: Available at http://www.esri.com/software/arcgis/extensions/spatialanalyst/. Accessed 2014 April 02.

Fageria, N.K. and A.S. Nascente 2014. Management of Soil Acidity of South American Soils for Sustainable Crop Production. Advances in Agronomy 128: 221-272.

Fang, S., B. Xie and J. Liu 2008. Soil nutrient availability, poplar growth and biomass production on degraded agricultural soil under fresh grass mulch. Forest Ecology and Management 255: 1802-1809.

FAO 2014. FAOSTAT - Statistical database. In FAOSTAT - Statistical database, Available at http://faostat.fao.org/site/567/DesktopDefault.aspx?PagelD=567\#ancor. Accessed 2014 May 23. Roma: FAO.

FAO 1976. A Framework for Land Evaluation. Rome: Soil Resources Development.

Fernández, C., J.A. Vega, E. Jiménez, D.C.S. Vieira, A. Merino, A. Ferreiro and T. Fonturbel 2012. Seeding and mulching + seeding effects on post-fire runoff, soil erosion and species diversity in Galicia (NW Spain). Land Degradation \& Development 23: 150-156.

Flanagan, D.C. and M.A. Nearing 1995. USDA-Water Erosion Prediction Project (WEPP). WEPP users summary. In USDA-Water Erosion Prediction Project (WEPP). WEPP users summary, National Soil Erosion Research Laboratory. USA, Indiana: USDA-ARS.

Fleskens, L. 2007. Prioritizing rural public works interventions in support of agricultural intensification. In Prioritizing rural public works interventions in support of agricultural intensification, IFDC and Helpage report. Kigali, Rwanda.

Foshee, W.G., W.D. Goff, M.G. Patterson, K.M. Tilt, W.A. Dozier, L.S. Tucker and J.S. Bannon 1999. Organic mulches affect soil and leaf nutrient levels of young pecan trees. Journal of Arboriculture 25: 176-182.

Gabre-Madhin, E.Z. and S. Haggblade 2004. Successes in African Agriculture: results of an expert survey. World development 32: 745-766.

Gasana, J.K. 1991. Classification des régions agro-bioclimatiques du Rwanda. Kigali-Rwanda.

Gentile, R., B. Vanlauwe and J. Six 2013. Integrated Soil Fertility Management: Aggregate carbon and nitrogen stabilization in differently textured tropical soils. Soil Biology and Biochemistry 67: 124-132.

Genton, M.G. 2000. The correlation structure of Matheron's classical variogram estimator under elliptically contoured distributions. Mathematical Geology 32.

Genton, M.G. 1998. Highly robust variogram estimation. Mathematical Geology 30.

Giller, K.E., E.C. Rowe, N. de Ridder and H. van Keulen 2006. Resource use dynamics and interactions in the topics: scaling up in space and time. Agricultural systems 88: 8-27. 
Giller, K.E., E. Witter, M. Corbeels and P. Tittonell 2009. Conservation agriculture and smallholder farming in Africa: the heretic's view. Field Crops Research 114: 23-34.

Gloria, M.B.A. 2002. Influence of potassium fertilization and roasting on bioactive amines profiles in coffee.

Hartemink, A.E. 2005. Plantation agriculture in the tropics: Environmental issues. Outlook on Agriculture 34: 11-21.

Hartemink, A.E. 2006. Soil Erosion: Perennial Crop Plantations. In Encyclopedia of Soil Science, ed. R. LAL, 1613-1617. Boca Raton: Taylor \& Francis.

Hassink, J. 1997. The capacity of soils to preserve organic $\mathrm{C}$ and $\mathrm{N}$ by their association with clay and silt particles. Plant and Soil 191: 77-87.

Hassink, J. 1992. Effects of soil texture and structure on carbon and nitrogen mineralization in grassland soils. Biology and Fertility soils 14: 126-134.

Hengl, T., G.B.M. Heuvelink and A. Stein 2004. A generic framework for spatial prediction of soil variables based on regression-kriging. Geoderma 120: 75-93.

Herencia, J.F. and C. Maqueda 2016. Effects of time and dose of organic fertilizers on soil fertility, nutrient content and yield of vegetables. Journal of Agricultural Science 154: 1343-1361.

lijima, M., Y. Izumi, E. Yuliadi, A. Sunyoto and M. Utomo 2003. Erosion control on a steep sloped coffee field in Indonesia with alley cropping, intercropped vegetables, and notillage. Plant Production Science 6: 224 - 229.

Janssen, R. and P. Rietveld 1990. Multi-criteria analysis and geographical information systems. An application to agricultural land use in the Netherlands. In Geographical Information Systems for Urban and Regional Planning, eds. H.J. Scholten and J.C.H. Stillwell, 129-139. Dordrecht: Kluwer Academic Publishers.

Jassogne, L., P.J.A. van Asten, I. Wanyama and P.V. Baret 2013. Perceptions and outlook on intercropping coffee with banana as an opportunity for smallholder coffee farmers in Uganda. International Journal of Agricultural Sustainability 11: 144-158.

Jensen, L.S., T. Salo, F. PImason, T.A. Breland, T.M. Henriksen, B. Stenberg, A. Pedersen and C. Lundström 2005. Influence of biochemical quality on $\mathrm{C}$ and $\mathrm{N}$ mineralization from abroad variety of plant materials in soil. Plant Soil 273: 307-326.

Joerin, F., M. Theriault and A. Musy 2001. Using GIS and outranking multi-criteria analysis for land use suitability assessment. International Journal of Geographical Information Science 10: 321-339.

Jordán, A., L.M. Zavala and J. Gil 2010. Effects of mulching on soil physical properties and runoff under semi-arid conditions in southern Spain. Catena 81: 77-85.

Kalburtji, K.L. and A.P. Mamolos 2000. Maize, soybean and sunflower litter dynamics in two physico-chemically different soils. Nutrients Cycling in Agro-ecosystem 57: 195-206. 
Karami, A., M. Homaee, S. Afzalinia, H. Ruhipour and S. Basirat 2012. Organic resource management: impacts on soil aggregate stability and other soil physico-chemical properties. Agriculture, Ecosystems and Environment 148: 22-28.

Khalil, M.I., M.B. Hossain and U. Schmidhalte 2005. Carbon and nitrogen mineralization in different upland soils of the subtropics treated with organic materials. Soil Biology and Biochemistry 37: 1507-1518.

Kong, A.Y.Y., J. Six, D.C. Bryant, R.F. Denison and C. van Kessel 2005. The relationships between carbon input, aggregation, and soil organic carbon stabilization in sustainable cropping systems. Soil Science Society of American Journal 69: 1078-1085.

Konig, D. 1992. The potential of agroforestry methods for erosion control in Rwanda. Soil Technology 5: 167-176.

Kosterna, E. 2014. The effect of covering and mulching on the soil temperature, growth and yield of tomato. Folia Horticulturae 26: 91-101.

Kravchenko, A. and D.G. Bullock 2000. Correlation of corn and soybean grain yield with topography and soil properties. Agronomy Journal 92: 75-83.

Kriegl, M. and R. Preissler 1987. Terrassement radical. In Terrassement radical, ed. Projet I.P.V. Kigali. Rwanda: Intensification de l'agriculture et de l'élevage.

Kwabiah, A.B., N.C. Stoskopf, C.A. Palm, R.P. Voroney, M.R. Rao and E. Gacheru 2003. Phosphorus availability and maize response to organic and inorganic fertilizer inputs in a short term study in Western Kenya. Agriculture Ecosystem and Environment 95: 4959.

Labouisse, J.P., B. Bellachew, S. Kotecha and B. Bertrand 2008. Current status of coffee (coffea Arabica L.) genetic resources in Ethiopia: implications for conservation. Genetic Resource Crop Evolution 55: 1079-1093.

Lal, R. 2015. Restoring soil quality to mitigate soil degradation. Sustainability 7: 5875-5895.

Lal, R., M. Ahmadi and R. M. Bajracharya 2000. Erosional impacts on soil properties and corn yield on Alfisols in Central Ohio. Land Degradation and Development 11: 575-585.

Lal, R. and W. Elliot 1994. Erodibility and erosivity. In Soil Erosion Research Methods. Soil and Water Conservation Society, ed. R. Lal, 181-208. USA: St. Lucie Press.

Lalljee, B. 2013. Mulching as a mitigation agricultural technology against land degradation in the wake of climate change. International Soil and Water Conservation Research 1: 68-74.

Lewis, L.A. 1988. Measurement and assessment of soil loss in Rwanda. Catena Supplement 12: $151-165$.

Lewis, L.A. and V. Nyamulinda 1996. The critical role of human activities in land degradation in Rwanda. Land Degradation and Development 7: 47-55.

Li, B., F. Zhang, L.W. Zhang, J.F. Huang, Z.F. Jin and D.K. Gupta 2012. Comprehensive suitability evaluation of tea crops using gis and a modified land ecological suitability evaluation model. Pedosphere 22: 122-130. 
Liu, Z, Z Chen, P Ma, Y Menga and J. Zhoua 2017. Effects of tillage, mulching and N management on yield, water productivity, $\mathrm{N}$ uptake and residual soil nitrate in a longterm wheat-summer maize cropping system. Field Crops Research 213: 154-164.

Loveridge, S. and J.B. Nyarwaya 2003. Decaffeinated? Situation, Trends and Prospects for smallholder coffee production in Rwanda - Analysis of a rural household survey - 2002. In Research Report, Policy Synthesis, ed. MINAGRI, 9-81. Kigali, Rwanda: Food Security Research Project (FSRP) \& Division of Agricultural Statistics (DSA).

Lugato, E. and A. Berti 2008. Potential carbon sequestration in a cultivated soil under different climate change scenarios: a modelling approach for evaluating promising management practices in North-East Italy. Agriculture, Ecosystems and Environment 128: 97-103.

Mafongoya, P.L. and P.K. Nair 1997. Multipurpose tree prunings as source of nitrogen to maize under semiarid conditions in Zimbabwe I. Nitrogen-recovery rates in relation to pruning quality and method of application. Agroforestry Systems 35: 31-46.

Maji, A.K., N.D.R. Krishna and O. Challa 1998. Geographical Information System in analysis and interpretation of soil resources data for land use planning. Journal of Indian Society of Soil Science 46: 260-263.

Maji, A.K., D.C. Nayak, N.D.R. Krishna, C.V. Srinivas, K. Kamble, G.P.O. Reddy and M. Velayuthan 2001. Soil information system of Arunachal Pradesh in a GIS environmental for land use planning. International Journal of Applied Earth Observation and GeoInformation 3: 69-77.

Malczewski, J 2004. GIS-Based land use suitability analysis: a critical overview. Progress in Planning 62: 3-65.

Malczewski, J. 1996. A GIS-based approach to multiple criteria group decision-making. International Journal of Geographical Information Systems 10: 955-971.

Manjith, K.B.R and S.S. Angadi 2016. Effect of tillage, mulching and weed management practices on the performance and economics of chickpea. Legume Research 39: 786791.

Masvaya, E.N., J. Nyamangara, K. Descheemaeker and K.E. Giller 2017. Tillage, mulch and fertiliser impacts on soil nitrogen availability and maize production in semi-arid Zimbabwe. Soil and Tillage Research 168: 125-132.

Mbonigaba, J.J., I. Nzeyimana, C. Bucagu and M. Culot 2009. Caractérisation physique, chimique et microbiologique de trois sols acides tropicaux du Rwanda sous jachères naturelles et contraintes à leur productivité. Biotechnologie, Agronomie, Société et Environnement 13: 545-558.

Mbonigaba, M.J.J. 2007. Etude de l'impact des composts à base de biomasse végétale sur la dynamique des indicateurs physico-chimiques, chimiques et microbiologiques de la fertilité des sols : application sur trois sols acides tropicaux du Rwanda. Faculté universitaire des sciences agronomiques, Université de Gembloux. 
McGregor, K.C., C.K. Mutchler and M.J. Römkens 1990. Effects of tillage with different crop residues on runoff and soil loss. Transactions of the ASAE 33: 1551-1556.

McKinion, J.M., J.L. Willers and J.N. Jenkins 2010. Spatial analyses to evaluate multi-crop yield stability for a field. Computers and Electronics in Agriculture 70: 187-198.

Merwin, I.A., D.A. Rosenberger, C.A. Engle, D.L. Rist and M. Fargione 1995. Comparing mulches, herbicides, and cultivation as orchard groundcover management systems. Horticulture Technology 5: 151-158.

MINITERE 2003. National strategy and action plan for the conservation of biodiversity in Rwanda. In National strategy and action plan for the conservation of biodiversity in Rwanda, ed. Ministry of Land and Environment Republic of Rwanda, 252. Kigali.

Miura, T., A. Niswati, I.G. Swibawa, S. Haryani, H. Gunito and N. Kaneko 2013. No tillage and bagasse mulching alter fungal biomass and community structure during decomposition of sugarcane leaf litter in Lampung Province, Sumatra, Indonesia. Soil Biology and Biochemistry 58: 27-35.

Moebius-Clune, B.N., H.M. van Es, O.J. Idowu, R.R. Schindelbeck, J.M. Kimetu, S. Ngoze, J. Lehmann and J.M. Kinyangi 2011. Long-term soil quality degradation along a cultivation chronosequence in western Kenya. Agriculture, Ecosystems and Environment 141: 8699.

Moguel, P. and V.M. Toledo 1999. Biodiversity conservation in traditional coffee systems of Mexico. Conservation Biology 13: 1-12.

Moore, I.D., P.E. Gessler and G.A. Nielson 1993. Soil attribute prediction using terrain analysis. Soil Science Society of American Journal 57: 443-452.

Morgan, R.P.C. 2005. Soil erosion and conservation. United Kingdom: Blackwell.

Mueller, T.G., N.B. Pusuluri, K.K. Mathias, P.L. Cornelius, R.I. Barnhisel and S.A. Shearer 2004. Map Quality for ordinary Kriging and inverse distance weighted interpolation. Soil Science Society of America Journal 68: 2042-2047.

Mukashema, A. 2003. Evaluation de la fertilité des sols et son impact sur la production du caféier Arabica dans le district de Maraba. Faculté d'Agronomie, Université National du Rwanda.

Mukuralinda, A. 2007. Influence of phoshorus resources on soil phoshorus dynamics and crop productivity in Rwanda, Makerere University, Uganda.

Mulumba, L.N. and R. Lal 2008. Mulching effects on selected soil physical properties. Soil and Tillage Research 98: 106-111.

Mupangwa, W., S. Twomlowd and S. Walker 2013. Cumulative effects of reduced tillage and mulching on soil properties under semi-arid conditions. Journal of Arid Environments 91: 45-52.

Murphy, R.P., J.A.M. Montes-Molina, B. Govaerts, J. Six, C. van Kessel and S.J. Fonte 2016. Crop residue retention enhances soil properties and nitrogen cycling in smallholder maize systems of Chiapas, Mexico. Applied Soil Ecology 103: 110-116. 
Murungu, F.S., C. Chiduza, P. Muchaonyerwa and P.N.S. Mnkeni 2011. Mulch effects on soil moisture and nitrogen, weed growth and irrigated maize productivity in a warmtemperate climate of South Africa. Soil and Tillage Research 112: 58-65.

Muschler, R.G. 2001. Shade improves coffee quality in a sub-optimal coffee-zone of Costa Rica. Agroforestry Systems 51: 131-139.

Mutwewingabo, B. 1989. Genèse, caractéristiques et contraintes d'amenagement des sols acides à horizon sombre de profondeur de la région de haute altitude du Rwanda. In Genèse, caractéristiques et contraintes d'amenagement des sols acides à horizon sombre de profondeur de la région de haute altitude du Rwanda, Actes du premier séminaire Franco-Africain de pédologie Tropicale. Lomé, Togo.

Mwango, S.B., B.M. Msanya, P.W. Mtakwa, D.N. Kimaro, J. Deckers and J. Poesen 2016. Effectiveness of mulching under Miraba in controlling soil erosion, fertility restoration and crop yield in Usambara Mountains, Tanzania. Land Degradation \& Development 27: $1266-1275$.

NAEB 2012. Action Plan for 2012 - 2013 Fiscal year. In Action Plan for 2012 - 2013 Fiscal year, National Agricultural and Export Board. Kigali, Republic of Rwanda.

NAEB 2011. Annual report 2010. In Annual report 2010, National Agricultural and Export Board. Kigali, Republic of Rwanda.

Nair, K.P.P. 2010. Coffee. In Coffee, The Agronomy and Economy of Important Tree Crops of the Developping World, 181-208.

Nearing, M.A., V. Jetten, C. Baffaut, O. Cerdan, A. Couturier, M. Hernandez, Y. Le Bissonnais, M.H. Nichols, J.P. Nunes, C.S. Renschler, V. Souchère and K. van Oost 2005. Modeling response of soil erosion and runoff to changes in precipitation and cover. Catena 61: 131-154.

Ngoma, H., N.M. Mason and N.J. Sitko 2015. Does minimum tillage with planting basins or ripping raise maize yield? Meso-panel data evidence from Zambia. Agriculture, Ecosystems and Environment 212: 21-29.

$\mathrm{Ni}$, X., W. Song, H. Zhang, X. Yang and L. Wang 2016. Effects of mulching on soil properties and growth of tea olive (Osmanthus fragrans). PLOS One 11: 1-11.

Nikolaidou, A.E., A.K. Pavlatouve, S.K. Kostopoulou, A.P. Mamolos and K.L. Kalburtji 2010. Litter quality and decomposition of Vitisvinifera L. residues under organic and conventional farming systems. European Journal of Soil Biology 46: 208-217.

NISR 2015. Statistical Yearbook. In Statistical Yearbook, ed. National Institute of Statistics of Rwanda. Kigali, Republic of Rwanda: National Institute of Statistics of Rwanda.

Nzeyimana, I., A.E. Hartemink and J. de Graaff 2013. Coffee farming and soil management in Rwanda. Outlook on Agriculture 42: 47-52.

Nzeyimana, I., A.E. Hartemink and V. Geissen 2014. GIS-based multi-criteria analysis for Arabica coffee expansion in Rwanda. PLOS One 9(10):e107449. 
Nzeyimana, I., A.E. Hartemink, C.J. Ritsema, L. Stroosnijder, E.H. Lwanga and V. Geissen 2017. Mulching as a strategy to improve soil properties and reduce soil erodibility in coffee farming systems of Rwanda. Catena 149: 43-51.

Okalebo, J.R., K.W. Gathua and P.L. Woomer 2002. Laboratory Methods of Soil and Plant Analysis: A working manual. Nairobi, Kenya: TSBF-CIAT and SACRED Africa.

Okeyo, A.I., M. Mucheru-Muna, J. Mugwe, K.F. Ngetich, D.N. Mugendi, J. Diels and C.A. Shisanya 2014. Effects of selected soil and water conservation technologies on nutrient losses and maize yields in the central highlands of Kenya. Agricultural Water Management 137: 52-58.

Okur, N., H.H. Kayikcioglu, F. Ates and B. Yagmur 2016. A comparison of soil quality and yield parameters under organic and conventional vineyard systems in Mediterranean conditions (West Turkey). Biological Agriculture and Horticulture 32: 73-84.

Oliveira, S.P., N.B. Lacerda, S.C. Blum, M.E.O. Escobar and T. S. Oliveira 2014. Organic carbon and nitrogen stocks in soils of northeastern Brazil converted to irrigated agriculture. Land Degradation and Development 26: 9-21.

Palm, C.A., C.N. Gachengo, R.J. Delve, G. Cadisch and K.E.. Giller 2001. Organic inputs for soil fertility management in tropical agroecosystems: application of an organic resource database. Agriculture, Ecosystems and Environment 83: 27-42.

Palm, C.A. and P.A. Sanchez 1990. Decomposition and nutrient release patterns of three tropical legumes. Biotropica 22: 330-338.

Park, S.J. and P.L.G. Vlek 2002. Environmental correlation of three-dimensional soil spatial variability: a comparison of three adaptive techniques. Geoderma 109: 117-140.

Pavan, M.A., J.C.D. Chaves, R. Siqueira, A.A. Filho, A.C. Filho and E.L. Balota 1999. High coffee population density to improve fertility of an Oxisol. Pesq. agropec. bras 34: 459-465.

Peeters, L.Y.K., L. Soto-Pinto, H. Perales, G. Montoya and M. Ishiki 2003. Coffee production, timber, and firewood in traditional and Inga-shaded plantations in southern Mexico. Agriculture, Ecosystems and Environment 95: 481-493.

Pimentel, D., C. Harvey, P. Resosudarmo, K. Sinclair, D. Kurz, M. McNair, S. Crist, L. Shpritz, L. Fitton, R. Saffouri and R. Blair 1995. Environmental and Economic costs of soil erosion and conservation benefits. Science 267: 1117-1123.

Poesen, J.W.A. and H. Lavee 1991 Effects of size and incorporation of synthetic mulch on runoff and sediment yield from interrills in a laboratory study with simulated rainfall. Soil and Tillage Research 21: 209-223.

Ponte, S. 2002. The "latte revolution"? Regulation, markets and consumption in the global coffee chain. World development 30: 1099-1122.

Prosdocimi, M., A. Jordán, P. Tarolli, S. Keesstra, A. Novara and A. Cerdà 2016a. The immediate effectiveness of barley straw mulch in reducing soil erodibility and surface runoff generation in Mediterranean vineyards. Science of the Total Environment 547: 323-330. 
Prosdocimi, M., P. Tarolli and A. Cerdà 2016b. Mulching practices for reducing soil water erosion: A review. Earth-Science Reviews 161: 191-203.

Ram, H., G. Singh and N. Aggarwal 2016. Effect of irrigation, straw mulching and weed control on growth, water use efficiency and productivity of summer mungbean. Legume Research 39: 284-288.

Rees, H.W., T.L. Chow, P.J. Loro, J. Lovoie, J.O. Monteith and A. Blaauw 2002. Hay mulching to reduce runoff and soil loss under intensive potato production in northwestern New Brunswick, Canada. Canadian Journal of Soil Science 82: 249-258.

Renard, K.G., G.R. Foster, G.A. Weesies, D.K. MsCool and D.C. Yoder 1997. Predicting soil erosion by water: A guide to conservation planning with the Revised Soil Loss Equation (RUSLE). USA: USDA.

Rezig, F.A.M., E.A. Elhadi and A.R. Mubarak 2013. Impact of organic residues and mineral fertilizer application on soil-crop systems I: yield and nutrients content. Archives of Agronomy and Soil Science 59: 1229-1243.

Romero, C.C., L. Stroosnijder and G.A. Baigorria 2007. Interrill and rill erodibility in the northern Andean Highlands. Catena 70: 105-113.

Romero, Y.A., L.S. Pinto, L. Garcia-Barrios and J.F. Barrera-Gaytan 2002. Coffee yields and soil nutrients under the shades of Inga sp. vs. multiple species in Chiapas, Mexico. Agroforestry systems 54: 215-224.

Roose, E. and F. Ndayizigiye 1997. Agroforestry, water and soil fertility management to fight erosion in tropical mountains of Rwanda. Soil technology: 109-119.

Rossiter, D.G. 1996. A theoretical framework for land evaluation. Geoderma 72: 165-190.

Rushemuka, N.P., R.A. Bizoza, J.G. Mowo and L. Bock 2014. Farmers' soil knowledge for effective participatory integrated watershed management in Rwanda: Toward soilspecific fertility management and farmers' judgmental fertilizer use. Agriculture, Ecosystems and Environment 183: 145-159.

Sanchez, P.A. 2015. En route to plentiful food production in Africa. Nature Plants 1: 1-2.

Sanchez, P.A. and B.A. Jama 2002. Soil fertility replenishment takes off in East and Southern Africa. In Integrated Plant Nutrient Management in Sub-Saharan Africa: From Concept to Practice, eds. B. Vanlauwe, J. Diels, N. Sanginga and R. Merckx, 23-45. New York: CAB International.

Santos, R., L. Rodrigues, C. Lima and C. Jaramillo-Botero 2012. Coffee yield and microenvironmental factors in a native tree agroforestry system in southeast Minas Gerais, Brazil. Journal of Sustainable Agriculture 36: 54-68.

Sariyildiz, T. and J.M. Anderson 2003. Interactions between litter quality, decomposition and soil fertility: a laboratory study. Soil Biology and Biochemistry 35 391-399.

Saroa, G. S. and R. Lal 2003. Soil restorative effects of mulching on aggregation and carbon sequestration in a Miamian soil in Central Ohio. Land Degradation and Development 14: 481-493. 
Schluter, J.E. and N.A. Finney 2000. Rehabilitation of coffee Rwanda development of washed processing within a framework of private investment. In Rehabilitation of coffee Rwanda development of washed processing within a framework of private investment. Nairobi-Kenya.

Shen, J.Y., D.D. Zhao, H.F. Han, X.B. Zhou and Q.Q. Li 2015. Effects of straw mulching on water consumption characteristics and yield of different types of summer maize plants. Plant Soil Environment 58: 161-166.

Shisanya, C.A., M.W. Mucheru, D.N. Mugendi and J.B. Kung'u 2009. Effect of organic and inorganic nutrient sources on soil mineral nitrogen and maize yields in central highlands of Kenya. Soil and Tillage Research 103: 239-246.

Shively, G. and J. Hao 2012. A Review of Agriculture, Food Security and Human Nutrition Issues in Uganda In A Review of Agriculture, Food Security and Human Nutrition Issues in Uganda, Purdue University Department of Agricultural Economics Staff. Purdue.

Simonsky, V., D. Bajcan and L. Ducsay 2013. The effect of organic matter on aggregation under different soil management practices in a vineyard in an extremely humid year. Catena 101: 108-113.

Smets, T., J. Poesen and A. Knapen 2008. Spatial scale effects on the effectiveness of organic mulches in reducing soil erosion by water. Earth-Science Review 89: 1-12.

Smith, O.H., G.W. Petersen and B.A. Needelman 2000. Environmental indicators of agroecosystems. Advances in Agronomy 69: 75-97.

Soltani, A., J.J. Stoorvogel and A. Veldkamp 2013. Model suitability to assess regional potato yield patterns in northern Ecuador. European Journal of Agronomy 48: 101-108.

Stagnari, F., A. Galieni, S. Speca, G. Cafiero and M. Pisante 2014. Effects of straw mulch on growth and yield of durum wheat during transition to Conservation Agriculture in Mediterranean environment. Field Crops Research 167: 51-63.

Staver, C., F. Guharay, D. Monterroso and R.G. Muschler 2001. Designing pest suppressive multistrata perennial crop systems: shade-grown coffee in Central America. Agroforestry Systems 53: 151-170.

Stoorvogel, J.J. and E.M. Smaling 1990. Assessment of soil nutrient depletion in Sub-Sahara Africa. In Assessment of soil nutrient depletion in Sub-Sahara Africa, ed. Report $\mathrm{N}^{\circ} 28$. Wageningen, The Netherlands: Winand Staring Centre.

Svoray, T. and S. Ben-said 2009. Soil loss, water ponding and sediment deposition variations as a consequence of rainfall intensity and land-use: a multi-criteria analysis. Earth Surf. Process. Land 35: 202-216.

Tao, Z., C. Li, J. Li, Z. Ding, J. Xu, X. Sun, P. Zhou and M. Zhao 2015. Tillage and straw mulching impacts on grain yield and water use efficiency of spring maize in northern Huang-HuaiHai Valley. The Crop Journal 3: 445-450.

Tejada, M. and J.L. Gonzalez 2007. Influence of organic amendments on soil structure and soil loss under simulated rain. Soil and Tillage Research 93: 197-205. 
Tejada, M. and J.L. Gonzalez 2008. Influence of two organic amendments on the soil physical properties, soil losses, sediments and runoff water quality. Geoderma 145: 325-334.

Thankamani, C.K., K. Kandiannan, S. Hamza and K.V. Saji 2016. Effect of mulches on weed suppression and yield of ginger (Zingiberofficinale Roscoe). Scientia Horticulturae 207: 125-130.

Tsozué, D., J.P. Nghonda and D.L. Mekem 2015. Impact of land management system on crop yields and soil fertility in Cameroon. Solid Earth 6: 1087-1101.

Tully, K.L., S.A. Wood, M. Almaraz, C. Neill and C. Palm 2015. The effect of mineral and organic nutrient input on yields and nitrogen balances in western Kenya. Agriculture, Ecosystems and Environment 214: 10-20.

Vaast, P., R. Van Kanten, P. Siles, B. Dzib, N. Franck, J.M. Harmand and M. Génard 2005. Shade: a key factor for coffee sustainability and quality. In Shade: a key factor for coffee sustainability and quality, Proceedings of the 20th International Conference on Coffee Science: 11-15 October 2004. Bangalore, India.

Van Asten, P.J.A., L.W.I. Wairegi, D. Mukasa and N.O. Uringi 2011. Agronomic and economic benefits of coffee-banana intercropping in Uganda's smallholder farming systems. Agricultural systems 104: 326-334.

Van der Eijk, D., B.H. Janssen and O. Oenema 2006. Initial and residual effects of fertilizer phosphorus on soil phosphorus and maize yields on phosphorus fixing soils: A case study in south-west Kenya. Agriculture, Ecosystems and Environment 116: 104-120.

Van der Vossen, H.A.M. 2005. A critical analysis of the agronomic and economic sustainability of organic coffee production. Experimental Agriculture 41: 449-473.

Van Oijen, M., J. Dauzat, J.M. Harmand, L. Gerry and P. Vaast 2010. Coffee agroforestry systems in Central America: II. Development of a simple process-based model and preliminary results. Agroforestry Systems 80: 361-378.

Vanlauwe, B., J.J. Ramisch and N. Sanginga 2006. Integrated soil fertility management in Africa: from knowledge to implementation. In Biological Approaches to Sustainable Soil Systems, eds. N. Uphoff, A. S. Ball, E. Fernandes, H. Herren, O. Husson, M. Laing, C. Palm, J. Pretty, P. Sanchez, N. Sanginga and J. Thies, 257-272. Boca Raton: CRC Press.

Vanzolini, J.I., J.A. Galantini, J.M. Martínez and L. Suñer 2017. Changes in soil pH and phosphorus availability during decomposition of cover crop residues. Archives of Agronomy and Soil Science 63: 1864-1874.

Verdoodt, A and E Van Ranst 2003. Land evaluation for agricultural production in the tropics: A large - scale land suitability classification for Rwanda. Ghent: Laboratory of soil science, Ghent University. ISBN: 90-76769-89-3.

Wairegi, L.W.I. and P.J.A. van Asten 2012. Norms for multivariate diagnosis of nutrient imbalance in arabica and robusta coffee in the East African Highlands. Expl. Agriculture 48: 448-460. 
Wairegi, L.W.I., P.J.A. van Asten, K.E. Giller and T. Fairhurst 2014. Banana-coffee System Cropping Guide In Banana-coffee System Cropping Guide Africa Soil Health Consortium. Nairobi, Kenya.

Walke, N., G.P. Obi Reddy, A.K. Maji and S. Thayalan 2012. GIS-based multicriteria overlay analysis in soil-suitability evaluation for cotton (Gossypium spp.): A case study in the black soil region of Central India. Computers and Geosciences 41: 108-118.

Wang, N., L. Jassogne, P.J.A. van Asten, D. Mukasa, I. Wanyama, G. Kagezi and K.E. Giller 2015. Evaluating coffee yield gaps and important biotic, abiotic, and management factors limiting coffee production in Uganda. European Journal of Agronomy 63: 1-11.

Wintgens, J.N. 2012. Biblio-establishment of coffee plantation. in biblio-establishment of coffee plantation, ed. J.N. Wintgens, Coffee: Growing, Processing, Sustainable Production. A Guidebook for Growers, Processors, Traders, and Researchers, 1022. Germany: Wiley-VCH.

Wu, Y., F. Huang, C. Zhang and Z. Jia 2016. Effects of different mulching patterns on soil moisture, temperature, and maize yield in a semi-arid region of the Loess Plateau, China. Arid Land Research and Management 30: 490-504.

Wuddivira, M.N., R.J. Stone and E.I. Ekwue 2013. Influence of cohesive and disruptive forces on strength and erodibility of tropical soils. Soil and Tillage Research 133: 40-48.

Xavier, F.A.S., S.M.F. Maia, K.A. Ribeiro, E.S. Mendonca and T.S. Oliveira 2013. Effect of cover plants on soil $\mathrm{C}$ and $\mathrm{N}$ dynamics in different soil management systems in dwarf cashew culture. Agriculture, Ecosystems and Environment 165: 173-183.

Yamoah, C.F., J.R. Burleigh and M.R. Malcolm 1990. Application of expert systems to study of acid soils in Rwanda. Agriculture, Ecosystems and Environment 30: 203-208.

Zech, W., N. Senesi, G. Guggenberger, K. Kaiser, J. Lehmann, T. M. Miano, A. Miltner and G. Schroth 1997. Factors controlling humification and mineralization of soil organic matter in the tropics. Geoderma 79: 117-161.

Zehetner, F. and W.P. Miller 2006. Erodibility and runoff-infiltration characteristics of volcanic ash soils along an altitudinal climosequence in the Ecuadorian Andes. Catena 65: 201-213.

Zhang, K., S. Li, W. Peng and B. Yu 2004. Erodibility of agricultural soils on the Loess Plateau of China. Soil and Tillage Research 76: 157-165. 


\section{English summary}

The Government of Rwanda would like to improve farming livelihood through the sustainable production of high quality coffee. This would be a win-win situation because improving farming livelihoods also provides increased export earnings. In order to fulfil this, the Government of Rwanda needs to design and support policies which sustain this growth. This can be achieved through an improvement programme of soil fertility and reduction of soil erosion, among other strategies. The programme should identify suitable areas for Arabica coffee production and assess sustainable land management technologies to improve soil fertility and reduce soil erosion to create conditions for optimizing production of high quality coffee. This PhD project contributes to those objectives. Experimental field measurements were conducted to assess the effects of mulch application on improving soil properties and reducing soil erosion, thus positively impacting yields. Assessments were made for three agro-ecological zones of Rwanda, namely the highlands, the central plateau and the shores of Lake Kivu.

The thesis covers a GIS Spatial analysis of coffee production systems at national level (chapters 2 and 3); at system and farm levels. It assessed the effects of best practices on soil erosion and soil fertility (chapters 4 and 5); and then it recommended best upscaling practices for a country level (chapters 3, 4, 5 and 6). Chapter 2 also reviewed coffee growing conditions, systems and soil management practices in Rwanda. Data showed that growing conditions are confined to an altitude range of $1,400-1,900 \mathrm{~m}$ a.s.l., an annual rainfall regime of $1,500-1,600 \mathrm{~mm}$, a temperature class of $18-22{ }^{\circ} \mathrm{C}$, and an average sunlight amount of 2,000 - 2,400 hours per year. Coffee is mainly grown along the shores of Lake Kivu, on the plateau in the central part of Rwanda, and in the Mayaga region located in the Southern-East part of the country. In these areas, coffee is mainly cultivated on moderate slopes and soils with low fertility. Coffee requires deep and finely-textured soils, which are well drained, aerated with moderate acidity (i.e. $\mathrm{pH}$ of 4.5 - 6.0) and moderate-to-high fertility. Many of the coffee farming lands in Rwanda do not accommodate these ideal conditions, e.g. steep slopes or scattered coffee plots intercropped with annual crops. Steep slopes, in particular, deplete soil fertility through soil erosion. The thesis looked at how mulching can assist with erosion control, improve soil properties and boost yields in such farming situations.

Chapter 3 assessed suitable areas for sustainably growing Arabica coffee, potential production zones, their productivity levels and the prediction of potential coffee yields. 
Results showed that coffee production zones cover about 32,000 ha, or about $2.3 \%$ of all cultivated lands in the country. About $21 \%$ of the country has a moderate yield potential, ranging between 1.0 and $1.6 \mathrm{t}$ coffee ha ${ }^{-1}$, mainly around the Central Plateau; $70 \%$ has a low yield potential $\left(<1.0 \mathrm{t}_{\text {coffee }} \mathrm{ha}^{-1}\right.$ ) mainly in the Eastern semi-dry lowlands and very cold highlands of the North-West of the country. Only $9 \%$ of the country has a high yield potential of 1.6 to $2.4 \mathrm{t} \mathrm{ha}^{-1}$, particularly around the shores of the Lake Kivu. The results have some variances depending upon the location and variable conditions in terms of agro-ecological zones.

Chapter 4 discusses the positive effects of different types of mulch. Again, the success of each area showed to be site-specific, with significant effects using a mixture of mulches composed of crop residues applied at a rate of above $20 \mathrm{t} \mathrm{ha}^{-1}$, where soil erodibility was reduced significantly (up-to 91\%). Clay content and silt particles are also noted to play a part. In fact, the association of soil organic carbon with clay and silt particles may be related to the amount of organic carbon that can be mobilised to saturate the clay and silt fractions on a particular soil texture.

Chapter 5 reports the positive effects of mulch on availability of soil nutrients to improve soil fertility and coffee yields. The amount of nutrient contents released after mulching was regulated by the amount of mulch biomass, the quality and type of mulch used, the climatic conditions and soil properties. Significant effects were obtained with a mixture of different types of mulch applied at a rate of above $20 \mathrm{t} \mathrm{ha}^{-1}$. Success results were also site-specific and additional application of inorganic fertiliser was recommended to obtain coffee yields of above $1.9 \mathrm{t} \mathrm{ha}^{-1}$. The inorganic fertiliser rates differ for each agro-ecological zone and soil type. The sustainability of coffee productivity could be ensured by intensifying the use of mineral fertilisers, but there are limited financial resources.

Chapter 6 presents a synthesis of our research findings and conclusions of the previous chapters. It highlights sustainable best land management practices that help to improve and optimise coffee productivity in smallholder farming systems. This chapter also presents key policy strategies and recommendations to improve coffee productivity of smallholder farmers in Rwanda. Besides the research results, conclusions and recommendations, the chapter highlights also a number of topics that remain to be addressed in order to understand more clearly the effects of mulching on soil fertility improvement and reduced soil erodibility, such as: (i) predicting coffee productivity through mapping of soil fertility indicators, (ii) modelling soil erosion of scattered smallholder coffee farms at microcatchment level, and (iii) assessing the quality and the effects of the organic mulches applied in small scale coffee farming systems, accounting for related costs and benefits for the farmer. 


\section{Nederlandse samenvatting}

De overheid van Rwanda wil het levensonderhoud van boeren verbeteren door het duurzaam produceren van kwalitatief hoogwaardige koffie. Dit zou een een win-win situatie kunnen zijn, aangezien toegenomen exportopbrengsten ook het levensonderhoud van boeren kunnen verbeteren. Om dit te realiseren, zou de Rwandese overheid beleid moeten ontwikkelen die deze groei kan stimuleren. Dit kan worden bereikt door middel van een programma, waarin onder andere wordt gefocust op het verbeteren van de bodemvruchtbaarheid en het reduceren van bodemerosie. Allereerst zouden geschikte gebieden voor de productie van Arabica koffie geïdentificeerd moeten worden. Ook technieken voor duurzaam landbeheer zouden gestimuleerd moeten worden om de bodemvruchtbaarheid te bevorderen en erosie te reduceren, ten behoeve van de productie van kwalitatief hoogwaardige koffie. Dit proefschrift draagt bij aan deze doelstellingen. Door middel van veldmetingen zijn de effecten getest van bodembedekkers op de verbetering van bodemeigenschappen, het reduceren van erosie, en verbeteren van de koffie oogst. De metingen zijn uitgevoerd in drie agro-ecologische zones in Rwanda: de hooglanden, het centrale plateau en de oevers van Lake Kivu.

Dit proefschrift bevat een ruimtelijke GIS analyse van koffieproductiesystemen op nationaal niveau (hoofdstuk 2 en 3), zowel op systeemniveau alsook op boederijniveau. Daarnaast zijn de effecten van best practices op bodemerosie en bodemvruchtbaarheid geëvalueerd (hoodstuk 4 en 5), en vervolgens zijn aanbevelingen gedaan voor het opschalen van best practices naar nationaal niveau. Hoofdstuk 2 evalueert ook de condities waaronder koffie groeit, de systemen en de werkwijzen voor bodembeheer in Rwanda. De data laten zien dat de groeicondities voor koffie optimaal zijn bij een hoogteligging tussen 1,400 en 1,900 meter boven zeeniveau, een jaarlijkse regenval tussen de 1,500 en 1,600 mm, temperaturen tussen 18 and $22^{\circ} \mathrm{C}$ en een gemiddeld aantal zonuren van 2,000 tot 2,400 per jaar. Koffie wordt voornamelijk verbouwd langs de oevers van Lake Kivu, op het plateau in centraal Rwanda en in de Mayaga regio in het zuid-oosten van het land. In deze gebieden wordt koffie met name verbouwd op middelmatig steile hellingen en op bodems met een lage bodemvruchtbaarheid. Het verbouwen van koffie vraagt om een fijne bodemstructuur en diepe bodems, die goed worden gedraineerd, en bij voorkeur met een matige zuurgraad ( $\mathrm{pH}$ tussen 4.5 en 6.0) en een gemiddelde tot hoge bodemvruchtbaarheid. Veel van de koffiegebieden in Rwanda voldoen niet aan deze ideale condities, doordat de productie bijvoorbeeld plaatsvindt op steile hellingen en op verspreide en gedeelde stukken land 
waar koffie en eenjarige gewassen via tussenteelt worden verbouwd. Steile hellingen zijn onderhevig aan erosie en putten hierdoor de bodemvruchtbaarheid uit. In dit proefschrift is onderzocht hoe bodembedekking kan bijdragen aan het verminderen en voorkomen van erosie, het verbeteren van bodemeigenschappen en het verhogen van de koffieoogst onder dergelijke omstandigheden.

Hoofdstuk 3 richt zich op het evalueren van geschikte gebieden voor het duurzaam verbouwen van Arabica koffie en het inschatten van potentiële productiviteitniveaus. De resultaten laten zien dat de productie van koffie op dit moment een gebied van circa 32,000 hectare beslaat, dat wil zeggen $2.3 \%$ van het landbouw areaal. Ongeveer $21 \%$ van Rwanda heeft een gemiddeld opbrengstpotentieel, variërend tussen 1.0 en 1.6 ton koffie ha- ${ }^{-1}$, met name rond het Centrale Plateau; terwijl 70\% een laag opbrengstpotentieel $(<1.0$ ton koffie $\mathrm{ha}^{-1}$ ) heeft, met name in gebieden in de oostelijke semi-droge laaglanden en de koude hooglanden in het noordwesten van het land. Slechts $9 \%$ van het land heeft een hoog opbrengstpotentieel van 1.6 tot 2.4 ton $\mathrm{ha}^{-1}$, gelegen in het gebied rondom Lake Kivu. Uiteraard is er ook binnen de verschillende zones ruimtelijke variatie door verschillen in bodem, helling etc.

Hoofdstuk 4 bespreekt de positieve effecten van verschillende vormen van bodembedekkers. Het succes van bodembedekkers hangt van de lokale context af; de erosiegevoeligheid van de bodem nam significant af (tot 91\%) in gebieden waar een mengsel van bodembedekkers is gebruikt in een hoeveelheid van $20 \mathrm{t} \mathrm{ha}^{-1}$. Het succes van bodembedekkers hangt niet alleen af van het mengsel zelf maar ook bijvoorbeeld van de bodemtextuur, structuur, en het organische stofgehalte.

Hoofdstuk 5 bespreekt de positieve effecten van bodembedekkers op de beschikbaarheid van bodemnutriënten ter verbetering van de bodemvruchtbaarheid en de koffieoogst. De hoeveelheid nutriënten die vrijgelaten wordt na het toepassen van bodembedekking, hangt af van de hoeveelheid biomassa van de bodembedekkers, de kwaliteit, het soort bodembedekker, de klimaatomstandigheden en de bodemeigenschappen. Significante effecten werden bereikt wanneer een mix van verschillende bodembedekkers werd toegepast in een hoeveelheid van meer dan 20 ton ha-1. Naast het gebruik van bodembekkers is extra toevoegen van anorganische meststof aanbevolen om koffieopbrengsten van meer dan 1.9 ton ha $^{-1}$ te realiseren. De hoeveelheid anorganische meststof verschilt per agro-ecologische zone en bodemtype. De duurzaamheid van koffieproductie kan worden veiliggesteld door het mede stimuleren van kunstmestgebruik, echter zijn hier maar beperkte financiële middelen voor aanwezig in de regio's.

Hoofdstuk 6 presenteert een synthese van de onderzoeksbevindingen, evenals de conclusies van voorgaande hoofdstukken. De beste werkwijzen voor duurzaam landbeheer 
die helpen bij het verbeteren en optimaliseren van de koffieproductiviteit in kleinschalige landbouw worden gepresenteerd en bediscussieerd. Tevens is er specifieke aandacht voor beleidsstrategieën en aanbevelingen die van beland zijn om de productiviteit van koffie te verbeteren in kleinschalige landbouwsystemen in Rwanda. Naast de onderzoeksresultaten, conclusies en aanbevelingen, benadrukt dit hoofdstuk ook een aantal thema's die verder moeten worden onderzocht om de effecten van bodembedekking op het verbeteren van bodemvruchtbaarheid en het reduceren van de erosiegevoeligheid nog beter te kunnen begrijpen, zoals i) het voorspellen van koffieproductiviteit door het beter in kaart brengen van bodemvruchtbaarheidsfactoren en indicatoren, ii) het modelleren van bodemerosie op verspreide kleinschalige koffieplantages in micro-stroomgebieden; iii) en het evalueren van de kwaliteit van organische bodembedekkers die worden toegepast in kleinschalige koffieplantages met inachtneming van de kosten en de baten van de boer. 


\section{Acknowledgements}

This PhD research was financially funded by the NUFFIC bilateral Project between the University of Rwanda and Wageningen University, the Netherlands under the NPT/RWA/061 project. I take also this opportunity to thank particularly the National Agricultural Export Development Board (NAEB), the Ministry of Agriculture and Animal Resources (GIS Unit), the Centre for Geographic Information System (CGIS) of the University of Rwanda and the International Soil Reference and Information Centre (ISRIC, Wageningen) that provided me with essential institutional support and office space during my PhD training period.

I would like also to express my pleasure and gratitude to the coffee farmers, associations and cooperatives of coffee farmers of the study sites, namely those of Kibirizi sector of Nyamagabe District, Ruli sector of Gakenke District, and Gishyita sector of Karongi District. Sincere and special gratitude goes to the coffee farmers who accepted to provide their fields for data collections and experimentation.

Much of the data used in this thesis was collected by coffee farmers and students of the Faculty of Agriculture at the University of Rwanda. It was a great pleasure for me when I was travelling with these students to collect data and to run field experimentation and take measurements. My lovely coffee farmers did very well in data collection; very smart farmers when you show them what to do and how to do it - they did a great job!

My special thanks and sincere gratitude to you Dr. Violette Geissen, Dr. Coen Ritsema, Dr. Alfred Hartemink, Demie Moore and Klaas Oostindie for your invaluable support in editing this thesis; without your help, support, understanding and willingness, this thesis would not have been possible.

Finally, to my lovely family, you have been very patient for long time to see the completion of this PhD. Moreover, I recognize your regular prayers and invaluable support along this long journey, particularly when I was combining my position at the Ministry of Agriculture and Animal Resources and at the Rwanda Agriculture and Animal Resources Development Board with a PhD training. 
For any person who provided any support, assistance and facilitation for the achievement of this PhD training, we would like to express our sincere gratitude.

Thank you all. 


\section{About the author}

Innocent Nzeyimana was born in Bujumbura, Burundi on $8^{\text {th }}$ March 1969. After high school, he was admitted to the University of Burundi in 1992, and later in 1995 after the Genocide against the "Tutsi" in Rwanda, where he joined the National University of Rwanda, Faculty of Agriculture, and graduated in 1998 as an Agricultural Engineer with specialization in Soil and Rural Engineering. From April 1999 to March 2012, he was recruited by this University to work as full-time Lecturer at the Faculty of Agriculture, in the Department of Soil Science and Environmental Management. At this Faculty of Agriculture, parts of the B.Sc and M.Sc courses he taught include "Soil and Water conservation; Soil Water Analysis and Management; Soil Physics I and II; Irrigation Design and Water Management; Erosion, Soil \& Water conservation; Site \& System Characterization", and supervised a number of theses for M.Sc and B.Sc degree students.

When he was still teaching at the National University of Rwanda, he was awarded a scholarship by the Government of Rwanda to study a Master of Science degree in Agriculture with specialization in Soil Physics at the University of Natal, Pietermaritzburg, School of Applied Environmental Sciences, Soil Science Department (from February 2000 to December 2003), where he worked with Professor Richard Haynes on the "Evaluation of conventional and No - tillage systems on soil physical conditions" as part of the M.Sc. thesis. In January 2006, he was awarded a PhD scholarship by NUFFIC-NPT/053 Project and later admitted at the Wageningen University, where he started to work under the supervision of Prof. Leo Stroosnijder and Dr. Alfred E. Hartemink. When Prof. Leo Stroosnijder retired in 2014, the supervision of Innocent Nzeyimana was taken care by Prof. Coen Ritsema, Prof. Violette Geissen and Dr. Alfred E. Hartemink.

Apart from the academic background, Innocent Nzeyimana was appointed by the Government of Rwanda in March 2012 as the Chairman of the Irrigation and Mechanization Agency under the Rwanda Ministry of Agriculture and Animal Resources. From March 2015 to-date, he is appointed as Rwandan Government official to work as the Head of Land Husbandry, Irrigation and Mechanization, one of the Departments at the Rwanda Agriculture and Animal Resources Development Board of the Ministry of Agriculture and Animal Resources. 
Publications related to this thesis

Nzeyimana, I., Hartemink, A.E., Ritsema, C.J., Stroosnijder, L., Lwanga, E.H., Geissen, V. 2017. Mulching as a strategy to improve soil properties and reduce soil erodibility in coffee farming systems of Rwanda. Catena 149: 43-51.

Nzeyimana, I., Hartemink, A.E., Ritsema, C.J., Mbonigaba, M.J.J., Geissen, V. 2018. Mulching effects on soil nutrient levels and yield of coffee farms in Rwanda. Submitted to Soil Use and Management.

Nzeyimana, I., Hartemink, A.E., Geissen, V. 2016. GIS-Based Multi-Criteria Analysis for Arabica Coffee Expansion in Rwanda. PLoS One 9(10): e107449. doi:10.1371/journal.pone.0149239.

Nzeyimana, I., Hartemink, A.E., de Graaf, J. 2013. Coffee Farming and Soil Management in Rwanda. Outlook on Agriculture, Vol. 42, No 1: 47-52, doi: 105367/oa.2013.0118.

Besides these peer-reviewed articles, there are other publications in a form of B.sc and M.Sc thesis reports that were conducted and supervised at the University of Rwanda as part of this research; these include:

Nkurunziza, P., Nzeyimana, I., 2013. Characterization of coffee farming systems in the southern Highlands: A case study of Kibirizi Sector of the southern Province. Supervised M.Sc thesis report. National University of Rwanda. Faculty of Agriculture.

Nyirandayisaba, C., Nzeyimana, I. 2013. Estimation of nutrient content in mulching material used in coffee farming systems of the Lake Kivu Borders Agro-Ecological Zone. Supervised M.Sc thesis report. National University of Rwanda. Faculty of Agriculture.

Mpagaritswenimana, V., Nzeyimana, I. 2011. Coffee mulching effect on soil and water conservation in smallholder farming system of the Northern Rwanda. Supervised M.Sc thesis report. National University of Rwanda. Faculty of Agriculture.

Nsengiyumva, D., Nzeyimana, I. 2011. Soil erodibility assessment in coffee farming systems in the Agro-ecological Zone of the Kivu borders. Supervised M.Sc thesis report. National University of Rwanda. Faculty of Agriculture.

Maniragaba, J.B., Nzeyimana, I. 2010. Estimation of nutrient partitioning into sterms, leaves and beans of coffee plants in coffee farming systems of the Lake Kivu Borders Agro-Ecological Zone. Supervised B.Sc thesis report. National University of Rwanda. Faculty of Agriculture.

Ndatimana, D., Nzeyimana, I. 2007. Effect of different types of mulch on soil chemical properties in small holder coffee fields. M.Sc thesis report. National University of Rwanda. Faculty of Agriculture. 


\title{
Co-author affiliations
}

\section{The Netherlands}

Soil Physics and Land Management Group (SLM), Wageningen University

Coen J. Ritsema

Violette Geissen

Leo Stroosnijder

Jan de Graaf

\section{United State of America \\ Department of Soil Science, FD Hole Soils Lab, 1525 Alfred E. Hartemink \\ Observatory Drive, 53706 Madison, WI, USA, \\ University of Wisconsin - Madison}

\section{Mexico \\ Agroecología. El Colegio de la Frontera Sur, Unidad \\ Campeche, Av. Poligono S/N, Cd. Industrial, Lerma}

Esperanza H. Lwanga

\section{Rwanda \\ College of Agriculture, Animal Production and \\ Veterinary Medicine, Department of Soil Sciences \\ University of Rwanda}

\author{
Jean Jacques M. Mbonigaba
}

This research was funded by NUFFIC bilateral cooperation between the University of Rwanda and Wageningen University under the NPT/RWA/061 project. The research was conducted at the Faculty of Agriculture of the National University of Rwanda in collaboration with coffee cooperatives working under the National Export Development Board (NAEB) umbrella. 


\section{PE\&RC Training and Education Statement}

With the training and education activities listed below the PhD candidate has complied with the requirements set by the C.T. de Wit Graduate School for Production Ecology and Resource Conservation (PE\&RC) which comprises of a minimum total of 32 ECTS ( $=22$ weeks of activities)

\section{Review of literature (6 ECTS)}

Soil erosion and soil fertility under coffee in Rwanda: a multiple-scale analysis (2006)

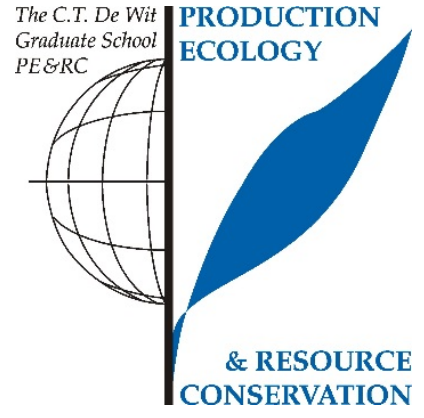

\section{Writing of project proposal (4.5 ECTS)}

Soil erosion and soil fertility under coffee in Rwanda: a multiple-scale analysis (2006)

\section{Post-graduate courses ( 12 ECTS)}

- Principles of remote sensing; ESRI and CGIS of the National University of Rwanda (NUR) (2006)

- Introduction to GIS and spatial data management; ESRI and CGIS, NUR (2006)

- $\quad$ Arc-GIS building databases; ESRI and CGIS, NUR (2006)

- NBI Training workshop in environmental impact assessment and environmental audit, Kigali, Rwanda; NBI/NELSAP (2006)

- $\quad$ Multivariate analysis and computing with GenStat and SAS; NPT-NUFFIC project NUR/WU/MOSAS-RWA (2007)

- $\quad$ Biometrics and data analysis; NUR/WU/MOSAS-RWA project (2007)

- Groundwater investigation, modelling and exploration, Alexandria, Egypt; NBTApplies training project (2008)

- Workshop on the development of the agricultural model for the Nile Basin Decision Support System (NB-DSS), Kampala, Uganda; NELSAP/RATP (2011)

\section{Laboratory training and working visits (1.2 ECTS)}

Working visit: Rwanda soil spatial analysis; Soil Laboratory, Ghent University (2007)

- Working visit: soil analysis by infrared spectroscopy; World Agroforestry Centre (ICRAF), CGIR-Nairobi (2008)

I nvited review of (unpublished) journal manuscript ( 1 ECTS)

- PLOSONE: simulation of biomass yield and soil organic $C$ under bio-energy sorghum production (2014)

\section{Deficiency, refresh, brush-up courses (1.5 ECTS)}

- $\quad$ ArcGIS DeskTop online course; ESRI and NUR (2006)

\section{Competence strengthening / skills courses ( 3 ECTS)}

- $\quad$ Scientific writing $\&$ publishing course; NPT-NUFFIC project NUR/WU/MOSAS-RWA (2007)

- Proposal, technical and scientific writing skill; RUFORUM, Entebbe, Uganda (2007) 


\section{Discussion groups / local seminars / other scientific meetings (9.8 ECTS)}

Soil conservation and land management; Rwanda Agricultural Board (2006-2009)

- $\quad$ Ecosystem conservation; Rwanda Environment Authority (2006-2009)

- Irrigation and water management; Rwanda Natural Resources Authority (20062009)

- $\quad$ Thematic working group meeting on integrated water resource management; Rwanda Natural Resources Authority (2006-2009)

- $\quad$ Agricultural sector working group meeting; Ministry of Agriculture and Animal Resources, Rwanda (2006-2009)

- Agricultural sector sub-working group meeting; Ministry of Agriculture and Animal Resources, Rwanda (2006-2009)

- $\quad$ Agricultural joint sector review meeting; Ministry of Agriculture and Animal Resources, Rwanda (2006-2009)

- $\quad$ Seminar on MSc and PhD research progress; NUR (2007)

\section{I nternational symposia, workshops and conferences (4.4 ECTS)}

- International workshop in agroforestry and soil management; poster presentation; Butare, Rwanda (2008)

- $\quad$ FAO Land and water days; oral presentation; Rome FAO HQ, I talia (2015)

\section{Lecturing / supervision of practical's / tutorials ( 3 ECTS)}

- $\quad$ Erosion, soil \& water conservation (2006-2009)

- $\quad$ Site \& system characterization (2006-2009)

- $\quad$ Soil water analysis and management (2009-2010)

\section{Supervision of MSc students}

- Effect of different types of mulch on soil chemical properties in smallholder coffee fields (2007)

- $\quad$ Costs and benefits of coffee production and land management in major coffee cropping systems of Rwanda (2009)

- $\quad$ Coffee mulching effect on soil and water conservation in smallholder farming system of the Northern Rwanda (2011)

- Soil erodibility assessment in coffee farming systems in the agro-ecological zone of the Kivu borders (2011)

- $\quad$ Effects of banana monoculture and banana-beans intercrop systems in erosion prevention on slope landscape (2013)

- Characterization of coffee farming systems in the Southern Highlands: a case study of Kibirizi Sector of the Southern Provence (2013)

- Estimation of nutrient content in mulching material used in coffee farming systems of the lake Kivu border agro-ecological zone (2013) 